\title{
GRASSROOTS POLITICS AND OIL CULTURE IN VENEZUELA
}

\author{
THE REVOLUTIONARY PETRO-STATE
}

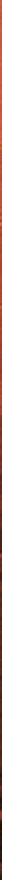

Iselin Åsedotter Strønen

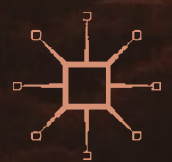


Grassroots Politics and Oil Culture in Venezuela 


\section{Iselin Åsedotter Strønen}

\section{Grassroots Politics and Oil Culture in Venezuela}

The Revolutionary Petro-State 
Iselin Åsedotter Strønen

University of Bergen

Bergen, Hordaland Fylke, Norway

Chr. Michelsen Institute (CMI)

Bergen, Hordaland Fylke, Norway

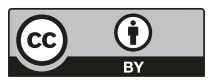

ISBN 978-3-319-59506-1

DOI 10.1007/978-3-319-59507-8

ISBN 978-3-319-59507-8 (eBook)

Library of Congress Control Number: 2017945573

(C) The Editor(s) (if applicable) and The Author(s) 2017. This book is an open access publication.

Open Access This book is distributed under the terms of the Creative Commons Attribution 4.0 International License (http://creativecommons.org/licenses/by/4.0/), which permits use, duplication, adaptation, distribution and reproduction in any medium or format, as long as you give appropriate credit to the original author(s) and the source, provide a link to the Creative Commons license and indicate if changes were made.

The images or other third party material in this book are included in the book's Creative Commons license, unless indicated otherwise in a credit line to the material. If material is not included in the book's Creative Commons license and your intended use is not permitted by statutory regulation or exceeds the permitted use, you will need to obtain permission directly from the copyright holder.

The use of general descriptive names, registered names, trademarks, service marks, etc. in this publication does not imply, even in the absence of a specific statement, that such names are exempt from the relevant protective laws and regulations and therefore free for general use. The publisher, the authors and the editors are safe to assume that the advice and information in this book are believed to be true and accurate at the date of publication. Neither the publisher nor the authors or the editors give a warranty, express or implied, with respect to the material contained herein or for any errors or omissions that may have been made. The publisher remains neutral with regard to jurisdictional claims in published maps and institutional affiliations.

Cover illustration: (c) Chad Ehlers / Alamy Stock Photo. All rights reserved, used with permission

Printed on acid-free paper

This Palgrave Macmillan imprint is published by Springer Nature

The registered company is Springer International Publishing AG

The registered company address is: Gewerbestrasse 11, 6330 Cham, Switzerland 


\section{To Cecilia}

May you live to see a more just and sustainable world 


\section{Preface}

Caracas, Venezuela, April 2011: Today I am meeting up with Miriam ${ }^{1}$ again, the community worker from the state institution Fundacomunal. As I approach the curve connecting the neighborhoods of Casalta 2 and Casalta 3, I can see her sitting in a jeep from the Ministerio del Poder Popular para la Energía y Petróleo (Ministry of Popular Power for Energy and Petroleum). We greet each other with a kiss on the cheek, and she introduces me to the two men accompanying her: Juan Carlos from the state-owned company Electricidad de Caracas (Electricity of Caracas), and Nelson from the Ministry of Popular Power for Energy and Petroleum.

Together, they have an inspection scheduled in the barrio (shantytown neighborhood) El Nazareno. The President's Office, which responds directly to President Hugo Chávez, has ordered the launch of Plan Zero Maraña (Plan Zero Spiderweb) in the entire Sucre parish, one of the largest and poorest neighborhoods in Caracas. The plan is to inspect all the chaotic homemade electric and telephone pole connections-hence the name spider web-and come up with solutions to make sense of the chaos. The money to carry out the plan will come from the state oil company PDVSA, ${ }^{2}$ Nelson from the ministry confides with a smile. PDVSA has financed innumerable social projects since Chávez came to power in 1998. 


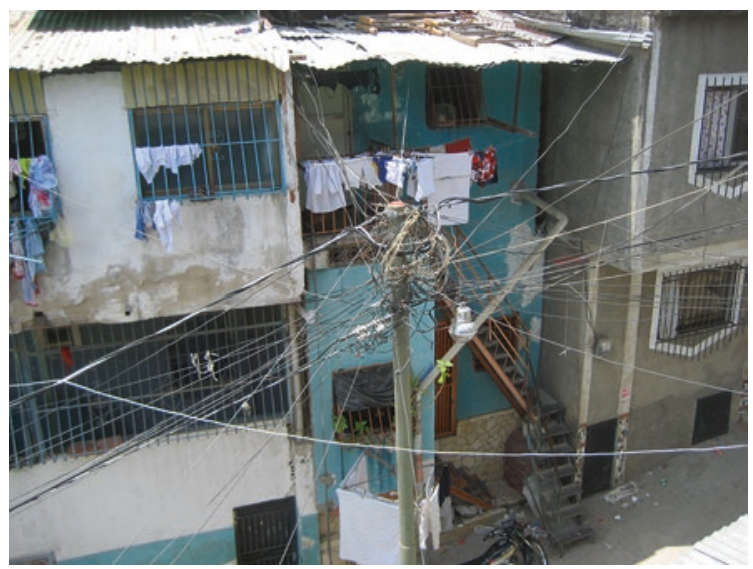

Photo 1 Typical electricity pole in informal neighborhoods. Photo by the author

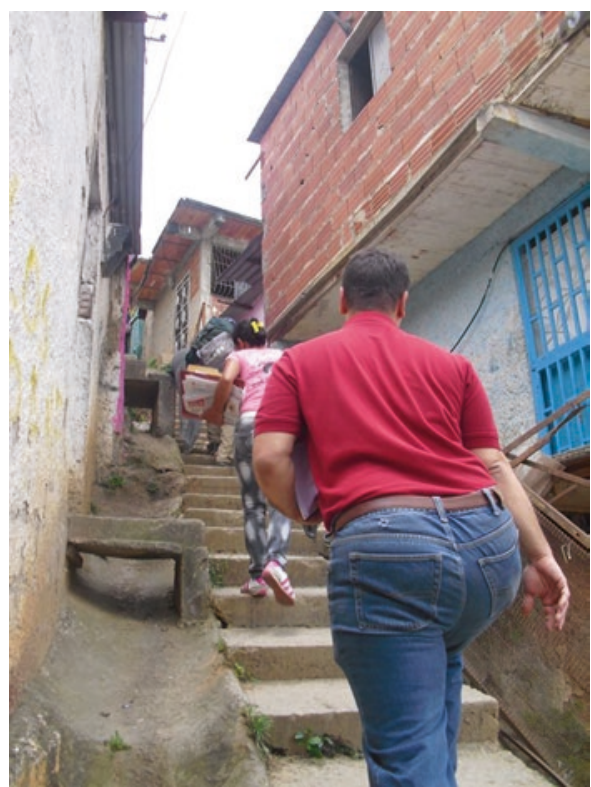

Photo 2 Inspection of electricity poles in el barrio of Nazareno. Photo by the author 
A tiny middle-aged woman named Maria is waiting for us down by the entrance to the barrio El Nazareno. She is the spokesperson for the social controllership committee in her consejo communal (communal council), as the local community organization for popular participation is called. Maria has serious eyes and a wrinkled face marked by the sun. She greets us and points upward toward where we are heading: a dense mass of brick shantytown houses stacked one on top of the other as far as the eye can see. These are informal settlements dating decades back, built brick by brick by barrio inhabitants and connected by thousands of small alleys and stairways. Maria, who has already been involved in several local projects to improve housing and infrastructure, will be our guide through the neighborhood. She already knows Miriam well, as Miriam helped form the communal councils and develop projects within the community.

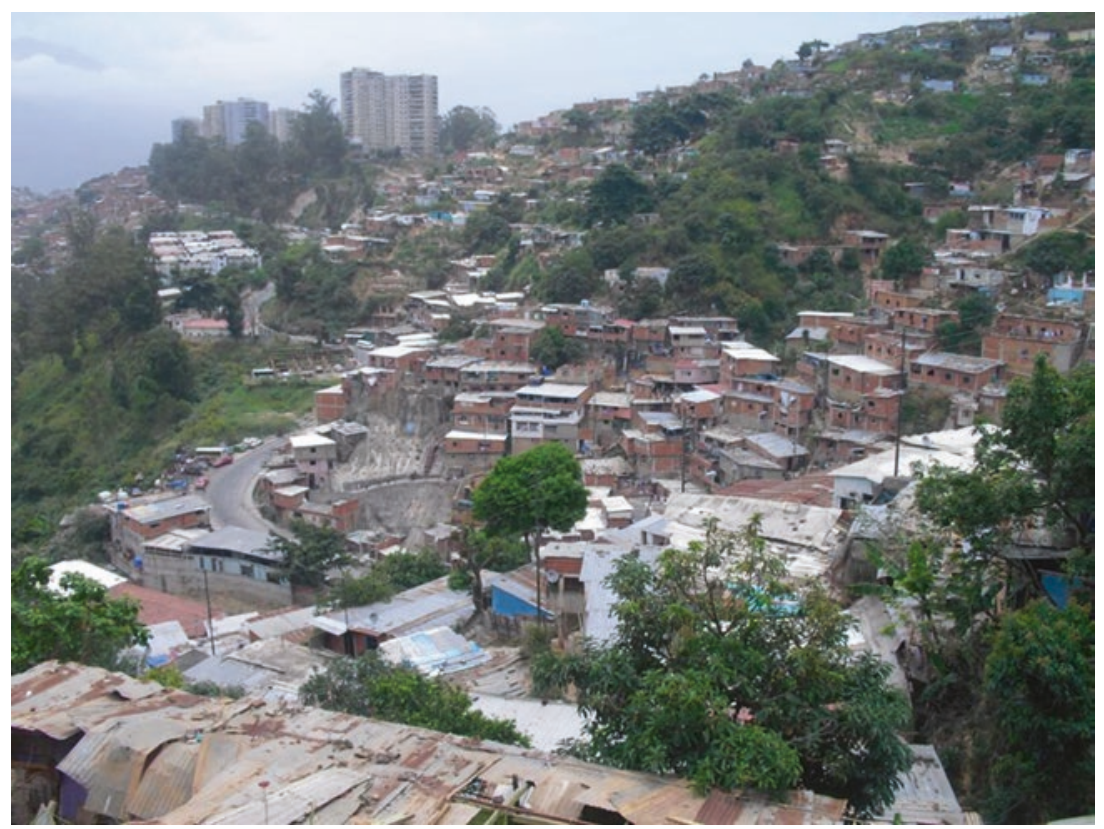

Photo 3 View from the barrio of el Nazareno toward Casalta 3 and Casalta 4. Photo by the author 
Already sweating in the morning sun, the five of us start to slowly climb up the steep stairs, joking about how the women in the barrios always have such nice buttocks due to their everyday involuntary exercise up these arduous hills. I have wanted to visit this barrio for a long time. I pass by it every day and it looks overwhelming and gigantic from the hill of Casalta 3 , where I currently live. It appears more like a mountain than a hill really, covered with tens of thousands of houses. I don't even want to think about how early in the morning the inhabitants at the top have to get up in order to arrive at work on time.

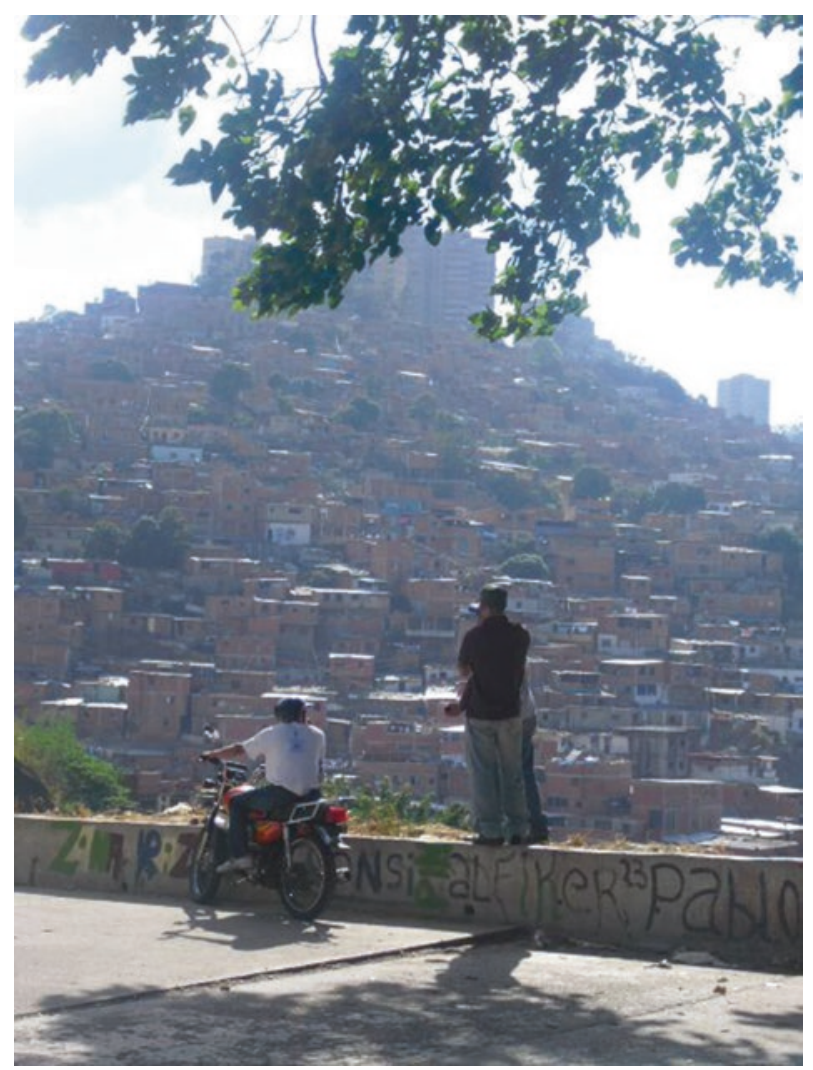

Photo 4 The barrios of Casalta and la Silsa, seen from 23 de Enero. Photo by the author 
Nelson from the Ministry of Energy and Petroleum asks me if I know why these barrios developed. "Well, the development of an oil economy and the subsequent migration from the countryside," I respond. He answers: "Well, yes that is one part of it, but the bottom line is capitalism, that is what happened. Capitalism is the bottom line of this." We chat about the complex problems of the barrios and I ask him if he thinks they will be resolved. He answers: "Well, the problem is so profound that my generation will not see it resolved, but there is hope for the next generation." We fall into silence and continue to climb slowly up the narrow concrete steps.

\section{Notes}

1. All names in this book are fictitious, unless they are cited in their capacity as public figures.

2. PDVSA: Petroleos de Venezuela S.A. 


\section{ACKNOWLEDGMENTS}

This book is the result of 12 years of academic engagement with Venezuela. Needless to say, I have not walked that path alone. First and foremost, I am deeply grateful to the countless Venezuelans who have generously given me their time and shared their thoughts, experiences, memories and opinions. Many have also extended me their friendship, and shared their food, drinks, homes, laughs, warmth and generosity with me. You made me feel at home in the barrios of Caracas, and I deeply admire the way you pursue your struggle for social justice with determination, wisdom, humor and kindness. A very special thank-you goes to "Miriam," "Ernesto," "Adrian," "Miche," "Rosa," "Oscar" and "Alfredo."

I conducted the main bulk of ethnographic research for this book as a member of the research project Flammable Societies. The Role of Oil and Gas Industry in the Promotion of Poverty Reduction and Social Volatility, financed by the Norwegian Research Council and led by John Andrew McNeish. Thank you to my co-project members for stimulating discussions and critical feedback on my work. I am particularly grateful to John Andrew McNeish, who in the capacity of being my supervisor during my doctoral work pushed my thinking and analytical ambitions. I also want to thank Hanne Müller, who was crucial for the conception of the Flammable Societies project in the first place, and who passed away all too early.

Throughout the years, I have had the privilege of sharing ideas and receiving feedback on my work from clever and kind colleagues at the Chr. Michelsen Institute (CMI) and the Department for Social Anthropology at the University of Bergen. In particular, I want to thank Karin Ask, Kari 
Telle, Inge Tvedten, Mari Norbakk, Gunnar Sørbø, Leif Manger, Margit Ystanes, Cecilie Ødegaard and Berit Angelskår.

I want to extend a very particular thank-you to Nefissa Naguib for her feedback on my work, and for her mentorship and friendship. Thank you also for bringing me on to the research project Everyday Maneuvers: Military-Civilian Relations in Latin-America and the Middle East, through which I was able to go back to Venezuela in 2014/2015.

In the process of bringing this book to its final form, I have benefited greatly from inputs and feedback from Nancy Postero and John Gledhill on my earlier work on Venezuela. Thank you so much.

I am deeply grateful to Vigdis Broch-Due, who was vital for molding my anthropological horizon as a master student in Anthropology of Development at the University of Bergen way back. Thank you for all your academic inputs, support and stimulating conversations throughout the years.

Thank you to all my colleagues at the Chr. Michelsen Institute (CMI) and the Department for Social Anthropology at the University of Bergen for providing such stimulating and fun work environments.

I am grateful to the anonymous reviewer at Palgrave who provided critical comments and constructive suggestions to this book project. Thank you also to the great people at Palgrave for your support: Mireille Yanow and Philippa Grand who handled the first phase of this book, and to Alexis Nelson and Kyra Saniewski for bringing it into its final form. Any mistakes and omissions appearing in the book are entirely my own responsibility.

My field research has been made possible by economic support from the Norwegian Research Council, the Lauritz Meltzer Research Fund and the Inger Haldorsen Memorial Fund. I also want to extend my gratitude to CMI and its director Ottar Mæstad for the generous funding of my fieldwork in 2012-2013. Thank you to the University of Bergen for funding Open Access-publication of this book.

Some of the ethnographic material appearing in this book has previously been published in "The Legacy of Hugo Chávez," Latin American Perspectives 44, no. 1 (2016): 159-179. Thank you for permissions to reuse the material. I want to extend a very special thank-you to Emilio Silva for granting me the permission to use and translate into English the text "What does it mean to be from Sambil Society?" (pp. 197-199). The text first appeared at the website www.apporea.org on June 2, 2005.

Maria Victoria Canino has been a very special person to me ever since I first came to Venezuela in 2005. Thank you for your practical support, 
sharp intellect, life wisdoms and above all, your enormous sense of humor, generosity, hospitality and cariño. I have learned so much from our conversations and discussions together, and I have enjoyed our diving trips immensely. My Venezuelan experiences would never have been the same without you. Te quiero mucho.

My deepest gratitude also goes to "my family" in Caracas: Zulay, el Moreno, Michel, Denis, Jayhi and Leyret, and the rest of the extended family clan. You have taught me so much about la vida a lo venezolano with all its quirks, joys and hardships, both in the past and in the present. Un abrazote a tod@s!

Life in academia can be a toilsome, time-demanding and at times lonely endeavor, but I have the privilege of having wonderful friends who always make me remember that there are other things to life as well. Thank you to Siv Mælen, for everything that you are, for always lending me an ear and for your wonderful friendship. Thank you to Merete Kjepso, who taught me my first salsa step and Spanish words as far back as in 1997. Thank you to Hildegunn Wrerness, who was my partner in crime in Venezuela throughout the work on our documentary in 2006-2007, habia fuego en el 23! Thank you to Berit Angelskar for your always stimulating conversations about academia and life. Thank you also to Ingrid Jæger, Leah Junge, Maria Hauso, Line Nrsse, Eirin Helene Moe, Hanne Louise Sunde and Lisa Reisig for your friendships. You all mean a lot to me.

My deepest gratitude goes to Keyler Monzon, who has accompanied me on a long stretch of this journey. Thank you for all your support, care, help and insights and, not least, for driving us through most of Venezuela's 23 states. Fue un tremendo viaje.

I am forever indebted to my parents, Åse Karin and Frode Strønen. You have supported me in every possible way ever since I embarked on my academic journey. For sure, this book would not have seen the light of day if it were not for you. I think you know how grateful I am, but I will say it once more: thank you so much. I could not have had better parents than you. Thank you also to my brother Daniel Strønen.

My final and deepest gratitude goes to my daughter Cecilia, who has been the most patient four-year-old in the world while "mummy has been writing her book." You have brought me joy, motivation and inspiration since the day you came into this world, and I dedicate this book to you. I look forward to the day when you can read this book. This is your story, too.

Bergen, February 4, 2017. 


\section{Contents}

1 Introduction 1

2 A History Written with Oil 29

3 Understanding the Bolivarian Revolution from Below 57

4 The Politics of Space, Race and Class 85

5 Contested Community Politics 111

6 The State as a Battlefield 157

7 Negotiating the Popular and the State 185

8 Moralities, Money and Extractive Capitalism 223

9 Collective Consumption and the Wealthy Nation-State 253 
xviii CONTENTS

10 Corruption and the Extractive State 279

11 Final Reflections: Understanding the "Revolutionary Petro-State"

Bibliography

Index 


\section{List of Figures}

Photo 1.1 The parish of 23 de Enero. Photo by the author

Photo 1.2 Some of the famous superbloques (apartment buildings) of 23 de Enero with the barrio la Pastora and the mountain ridge Ávila in the background. Photo by the author

Photo 1.3 Public meeting about the communal councils in the National Assembly. Photo by the author

Photo 1.4 Mural of Che Guevara, 23 de Enero. Photo by the author

Photo 1.5 Barrio houses, 23 de Enero. Photo by the author

Photo 2.1 Poster of Che Guevara made by the Ministry for Energy and Petroleum. It reads: "with energy we sow oil and we sow consciousness in order to form the new man and construct a new society." Photo by the author

Photo 4.1 Private homes in Eastern Caracas. Photo by the author

Photo 4.2 The statue of Simón Bolívar at Plaza Bolívar, downtown Caracas. Photo by the author

Photo 5.1 A typical module of Barrio Adentro in 23 de Enero. Photo by the author

Photo 5.2 Elections in a communal council in 23 de Enero. Photo by the author

Photo 5.3 A deteriorated football field, a Barrio Adentro module and informal housing constructions in 23 de Enero. Photo by the author

Photo 7.1 A Casa de Alimentación (soup kitchen) in 23 de Enero. Photo by the author

Photo 7.2 The barrio of Antímano. Photo by the author 
Photo 7.3 Public meeting with Jorge Rodríguez, the mayor of the Libertador Municipality, in 23 de Enero.

Photo by the author

Photo 9.1 Ranchos in Casaalta 4, according to local residents built in unstable soil. Photo by the author

Photo 9.2 New home built through a communal council housing project. This kind of project is referred to as sustitución de ranchos por casas (substitution of ranchos (shacks) for homes). Photo by the author

Photo 9.3 New roof acquired through a communal council project. Photo by the author

Photo 9.4 Barrio homes in el Nazareno. Photo by the author 261

Photo 11.1 March and public meeting with President Chávez in Avenida Bolívar, May 1, 2011. Photo by the author 


\section{LIST OF TABLES}

Table 5.1 Results from roundtable discussion in the Parish of 23 de Enero, March 2009

Table 7.1 Points from workshop discussions about how to analyse and elaborate a community project. The parish of 23 de Enero, Caracas, February 2010 


\section{Introduction}

In the period between 1999 and 2013, the late president Hugo Chávez spearheaded a broad social and political transformation in Venezuela, frequently referred to as the Bolivarian revolution. This concept took inspiration from the nation's great hero from the Wars of Independence, Simón Bolívar, whose ideas about national sovereignty and social justice also left him with a legacy as a great political thinker. At the heart of the Bolivarian revolution, or Bolivarian process as it is often referred to, was an upsurge of popular mobilization emerging from the country's poor and previously marginalized majority. Through participatory social and political policies and legislation, and drawing on decades of grassroots mobilization, the urban shantytowns in particular were converted into a hotbed of social activism. This mobilization went in tandem with government-led attempts to reform the state institutions into being socially responsive and politically inclusive instruments for concretizing the Bolivarian revolution's ideals of poder popular (popular power) and social inclusion.

When Chávez died from cancer in March 2013, the country's poor poured into the streets crying. In the more prosperous neighborhoods however, the home of the country's middle and upper class, celebratory fireworks went up in the air and champagne bottles were popped. Venezuela under Chávez had in no way been a socially harmonious society. His entry into the presidential palace has caused a massive displacement of political, economic and cultural power. During the 40 years prior to Chávez's 1998 electoral victory, the middle and upper classes had enjoyed a near hegemonic position in Venezuelan society, relegating the poor and

(C) The Author(s) 2017

I.Å. Strønen, Grassroots Politics and Oil Culture in Venezuela, DOI 10.1007/978-3-319-59507-8_1 
colored majority to a life of social marginalization and everyday hardships. With Chávez in the presidential palace, the poor took on a new role in Venezuelan society as the stewards of new social ideologies, cultural politics and political reforms. This turning of tables generated deep political polarization in Venezuelan society, mobilizing divisions along racial- and class-based social cleavages rooted in the country's colonial history.

\section{At An IMPASSE}

Today, four years after Chávez's death, Venezuela is far from fulfilling the ideals that the Bolivarian process harbored. The country is ravaged by economic hardships, and the political scene is characterized by a political stalemate between the Maduro government and the opposition who won a landslide victory in the elections to the National Assembly in December 2015. This was their first electoral success since Chávez came to power 17 years earlier. President Nicholas Maduro has record-low backing, and many social activists have become disillusioned and abandoned politics altogether. Others are struggling to gain new foothold for the Bolivarian process and to resist the oppositions' bid to regain political, economic, cultural and social power. That is, a new page has been turned in Venezuelan history, and the ambitious ideals of the Bolivarian revolution are seemingly left obsolete.

However, the fact that the Bolivarian revolution apparently has reached an impasse makes it even more compelling to try to understand what actually took place during its most intense period when Chávez was still alive. Indeed, for many years, Venezuela was the epicenter for the so-called leftist turn in Latin America, as well as a source of inspiration of so-called anti-imperialist and anti-globalization activists and movements across the world. The charismatic and always outspoken Chávez drew crowds of people to popular assemblies from Argentina to London, and he was the spider in the web for a growing number of Latin American governments who sought - to various degrees - to reverse the USA's political and economic grip over the continent. Significantly, the Chávez government regained control over the country's semi-privatized oil-industry that for years had benefited foreign oil companies more than the majority of the Venezuelan population. This move, in combination with historically high oil prices, enabled the enactment of myriad of social policies that rapidly reduced the country's poverty rates and inequality index. Venezuela's poor and colored majority population embraced Chávez, who was the first 
president in the country's history with an impoverished background and black and indigenous heritage like themselves. In short, Venezuela was frequently referred to as evidence of the anti-globalization movement's slogan "another world is possible," challenging Francis Fukuyama's wellknown postulate about liberal democracy and capitalism as "the end of history" (Fukuyama 1992).

\section{Complicating the Picture}

However, this is evidently the short and simplified version of Venezuela during the Chávez years and not of much worth if we want to understand in depth the complexities and difficulties characterizing the unfolding of the Bolivarian revolution. Neither is it of much worth if we search for a more nuanced understanding of the Bolivarian revolution's successes as well as difficulties - and how these came about. It is my belief that through exploring these questions we can achieve a fuller comprehension-also on a more theoretical level — of the difficulties inherent in processes aimed at fomenting deep social change and political transformations. This is a lesson that can be valuable for political struggles elsewhere and at other times.

Thus, this book tells a lot more complex tale, taking as a point of departure a broad analysis of social and political change in Venezuela seen from the point of view of the barrios (shantytowns) of Caracas where the majority of Chávez's supporters were found. ${ }^{1}$ By exploring political history and social life in the barrios, local arenas for political activism as well as the relationship between barrio communities and the Venezuelan state under Chávez, I will argue that the popular sectors ${ }^{2}$ under Chávez's passed through a significant transformation. In simple terms, they moved from a state of historical marginalization to feeling part of a project of social development and nation-building. However, the processes taking place in Venezuela also brought out in stark relief the challenges in altering social relationships, political dynamics and cultural imageries in accordance with the ideology of radical social transformation that the Chávez government, and many of its supporters, articulated. Through in-depth explorations of people's hopes, aspirations and actions, this book shows how the Bolivarian process was in essence a struggle over attempts to create new moral economies, new cultural values and new forms for social and political life. Indeed, to social activists in the Venezuelan shantytowns, "the Bolivarian revolution" or "Socialism for the twenty-first century," 3 as 
it later also was called, were not abstract slogans. Rather, they represented a day-to-day lived experience, filled with joy, frustrations, setbacks and victories, as people were trying to change themselves, their immediate life worlds as well as their society more broadly.

In the midst of this struggle was an attempt to transform the Venezuelan state from below, into a more just, socially responsive and democratic entity. However, the ethnographic explorations offered in this book illustrate the intrinsic difficulties in fomenting changes at the level of the state. It shows how the everyday politics, ingrained practices as well as ideas associated with the "old" Venezuelan state were challenged, negotiated and reproduced in the midst of a process of radical political reform, and how these dynamics brought up deep tensions and contradictions in the midst of the Bolivarian process. Seen together, these analyses will provide a vivid imagery of the interplay between what social scientists favor to call "structure" and "agency"; the historico-cultural legacies and sociopolitical structures conditioning the Bolivarian process's possibilities and limitations, as well as the multiple and differently socially situated actors that shaped its everyday and long-term dynamics.

\section{A Revolutionary State}

Much has been said and written about the relationship between Chávez and his supporters. Frequently depicted as a charismatic populist ${ }^{4}$ in the mainstream media, the underlying script indicated that people were seduced by his charisma and style. Another frequent subtext is that the poor were "bought" by generous government programs targeted toward underprivileged communities. In this book I aim to show that both of these postulates are superficial at best, failing to respect not only poor people's political agency, but also the variety of personal motivations for supporting Chávez found among his supporters. If we fail to take into account the long history of popular protests and contestations emerging from the popular sectors as well as the political narratives and collective memories shaping a "Bolivarian" ideology and political agency from below, we do not achieve a proper understanding of the historical origins of, and dynamics within, the Bolivarian revolution.

Throughout this book I will place everyday political action in the barrios in a broader social, political and historical context, and argue that the convergence between political agency and ideology from the grassroots and the political project of the Chávez government opened up a political space which I have chosen to call a Bolivarian space. The Bolivarian space 
is the complex conundrum of political discourses, practices, policies, historical narratives and ideological templates that shaped the interaction between the state and the popular grassroots in Venezuela under the Chávez government. This was not a top-down process whereby Chávez univocally imposed a political idea from above. Rather, it was a flow of multi-directional processes that were shaped by popular efforts to appropriate the political space opened up by the Chávez government's pro-poor political alignment. While the popular sector grassroots did have both an affective and political rapport with the Chávez government, they were well aware that their struggle went beyond having a sympathetic government in power. The popular grassroots' struggle was both a political and a socio-cultural one, challenging a legacy of centuries of accumulated inequalities and exclusion, as well as a historical state formation that posed severe obstacles not only for popular sector activism, but also for the government's efforts to enact political reform from above. In that process, the popular sectors took a stance that might be termed "strategic ambiguity" in the words of Aymaran scholar Pablo Mamani (Fernandes 2010:28). "Strategic ambiguity" refers to the manner in which social movements are:

identifying themselves as a part of the state in order to highlight the new form of access and inclusion they have opened up, but maintaining a sense of their autonomy to be able to put pressure on the state when necessary. (Fernandes 2010:28)

As I will show, popular political mobilization drew on a long history of struggle, and was fused with new narratives and practices as people became identified with the Bolivarian revolution and entangled into the government's project of social development and nation-building. This relationship constituted in many respects a new model of dignity (Gledhill 2000:27), whereby poverty and marginalization was converted into a source of collective identity formation and political agency instead of being associated with shame and social stigma.

\section{The Lens of OIL}

Over the past years, a handful of ethnographically oriented books have come out that focuses on popular politics emerging from Venezuela's grassroots movements in the Chávez era (Fernandes 2010; Ciccariello-Maher 2013; Valencia 2015). While this book complements and expands on the insights emerging from these books, my analytical scope does not stop there. 
Throughout, I will frame my analysis of the dynamic relationship between barrio communities and the Venezuelan state through a very particular perspective: one that seeks to understand the everyday unfolding of the Bolivarian process through the lens of oil. The epigraph above, recounting my barrio-inspection together with Miriam, Nelson, Juan Carlos and Maria, points to the salience of oil-fuelled capitalism as an entry point into the nation's historical development, self-understanding, as well as state policies in the Chávez era. Venezuela, currently the world's fifth largest oil exporter, has been characterized as a petro-state par excellence (Karl 1997). The country found oil in 1914, long before formal democracy was installed, and by the end of the 1920s, it was the largest oil exporter in the world. Rivers of ink have been spent on explaining oil's political and economic effects and consequences (Mommer 1996, 2004; Karl 1997; Pérez Alfonzo 2011 [1976]), yet the nation's history as a petro-state has yet not been explored in relation with an analysis of the social and political processes taking place in Venezuela's barrios and within its state institutions during the Chávez years. This is precisely what this book sets out to do.

\section{The Revolutionary Petro-state}

One might ask: what has grassroots mobilization and social policy reform to do with oil? The answer is: if one looks closely enough, a lot of things. The first book that I read about Venezuela before I embarked on my first research trip to Venezuela in 2005 was the late Fernando Coronil's seminal work The Magical State. Nature, Money and Modernity in Venezuela (1997). Here, the Venezuelan-American historian and anthropologist seeks to bring together not only how oil rents shaped Venezuelan state formations, but also how the conceptualization of the relationship between the state, society and nature shaped social relationships and political dynamics. The title of the book, The Magical State, reflects the idea of the Venezuelan state as seen by its citizens, a state capable of doing great things and transforming the nation through appropriating and putting to use oil rents gushing up from beneath. In one of his key passages, Coronil writes:

I argue that the deification of the state took place as a part of the transformation of Venezuela into an oil nation. As an oil nation, Venezuela was seen as having two bodies, a political body made up from its citizens, and a natural body made up from its rich subsoil. By condensing within itself the multiple powers dispersed throughout the nation's two bodies, the state appeared as a single agent endowed with the magical power to remake the nation. (Coronil 1997:4) 
In his account, Coronil weaves together an analysis of how Venezuelan citizens "saw" the Venezuelan state, personified by its magician-like politicians, with an analysis of how this imagery and the Venezuelan state's projection of itself was crafted by Venezuela's subjugated position within global hierarchies of power. ${ }^{5}$ Coronil invites the reader into a labyrinthine journey through Venezuela's political economy, political affairs, public scandals and spectacles of power, ultimately showing how the imagery of the grandiose Venezuelan state, both in its material and symbolic form, slowly imploded throughout the 1980s and 1990s.

\section{The Absence of the Subalterns}

"The Magical State" is a story told from "the highest centres of political power" (Coronil 1997:15). It is a tale about the spectacles of the Venezuelan elites at different historical conjunctures, and not so much about how this idea of the state was absorbed and interpreted by "the masses." Coronil himself was aware of this, acknowledging that writing from "the spheres of power" engenders the risk of excluding the subordinated sectors from view, converting them into "shadowy figures in the background" (Coronil 1997:15). This in turn, he argues, "unwittingly tends to reinscribe the arrogant view from above and reproduce its selfproclaimed universality and fundamental disregard for the lives and forms of knowledge of subaltern subjects" (Coronil 1997:16). Although he wanted to weave subaltern perspectives into his account, they are nevertheless absent in his text. To the extent that they are present, it is in the form of a shared relation of subordination together with the rest of the Venezuelan nation as mirrored through hegemonic notions of modernity and development emanating from the Global North. However, the poor's voices and lives aren't heard or seen, and it remains opaque how subaltern lives were actually lived in the shadows of the oil-fuelled spectacles at the top.

\section{Petroleum and People}

Coronil's account ends in 1997, one year before Chávez gained power. Throughout my years of engagement with Venezuela, his work has lingered in the back of my mind, haunting me with the question: how is the Venezuelan oil state imagined and encountered from the poor's points of view? This book explores this question through examining people's memories from and experiences living on the margins of the twentieth-century 
Venezuelan oil state that Coronil analyzed. At the same time, it extends this line of thought through inquiring into how the imagery and sociopolitical architecture of the Venezuelan oil state shaped the Bolivarian processes in the Chávez era. Thus, this book is inspired by Coronil's deep insights into Venezuelan society, while at the same time I locate my analysis in a different ethnographic space, context and temporality.

There is a growing body of literature on the cultural, epistemic and material dimensions of oil, seemingly inspired not only by an acute awareness of how our lives are both materially and viscerally saturated and shaped by oil in the age of capitalist modernity, but also of the looming threat, or even mass-destruction, that oil's omnipresence appears to harbor. The current renewed interest in oil is considered a "third" wave of oil- and energy scholarship within anthropology (Rogers 2015:366). Challenging the political-science-dominated concept of "the resource curse" (Sachs and Warner 1995, 2001; Collier and Hoeffler 1998, 2000, 2005; Rosser 2006), anthropological approaches favor to explore and theorize how oil itself as well as the industries that extract it and put it into circulation "enter social, cultural, political, and economic relationships" (Rogers 2015:370-371).

This book aligns itself with this line of thinking, through adapting a perspective that sees oil wealth as a formative agent of multiple and interlinked aspects of Venezuelan society (Coronil 1997; Tinker Salas 2009). However, my analytical scope is conditioned by the ethnographic field that I am concerned with. Thus, I am not striving for an analysis of the oil economy per se. Rather, I am focusing on how Venezuelan social, cultural and political formations - such as its political system, state apparatus, class relations, urbanization processes and national identities-were shaped by the country's history as a petro-state, and how these formations were challenged, transformed and fought over during the Chávez era. Moreover, I do not seek to establish a stringent analysis of how exactly oil wealth entered and circulated in the political and social system during the Chávez era, but to better understand the multi-faceted ways in which oil wealth gained salience as a material resource, a social property and a cultural imagery.

My analytical purpose for coining the concept "lens of oil" is therefore to tease out oil wealth's multiple properties as it enters social relations, while also underlining how its social dimensions are intertwined with its structural embeddedness in local and global political economies. Logan and McNeish (2012) argue that we need to do a "qualitative 
analysis of the interface between the political dynamics of global capitalism, on the one hand, and local processes of value formation, personhood, histories and relationships to resources, on the other" (Logan and McNeish 2012:30). Taking cue from these insights, this book is guided by a curiosity to explore the effects of oil in a place that was first marginalized from, and then brought into the center of the Venezuelan petrostate, that is, the barrios. Concurrently, I locate this ethnography within a broader analysis of how Venezuela was shaped as an oil state and oil society through the confluences of local and global processes. In doing so, I am also thinking through the continuities as well as transformations characterizing Venezuela's history with oil in both its structural and imaginative dimension.

\section{KNOWING OIL}

To that end, this book will take you through a critical reading of Venezuela's historical formation as a petro-state, followed by an analysis of how the lives and identities of the poor were shaped in the shadows of the oil-fuelled Venezuelan state in the latter part of the twentieth century. I will show how this particular dimension of Venezuela's socio-political history was constitutive of how class identities and political imaginaries were formed, and ultimately a catalyst for enabling Chávez's rise to power and shaping the Bolivarian process' imaginary horizon. Concurrently, I will turn my attention to how the Venezuelan poor came "to know oil" (Rogers 2015:374) through social policies and participatory politics, making poor people feel that they were finally granted "their drop of oil."

At a material level, poverty alleviation and increased welfare during the Chávez era was boosted by the government's decision to spend large chunks of the country's oil wealth on pro-poor policies. In that sense, the ethnographic analysis provides for an exploration of participative models for redistribution and collective consumption in the context of particular political-economic conjuncture in an oil-rich state. But this mode of government spending also gained a deeper meaning. On the backdrop of people's historical memories of being negated a share in the nation's riches, social spending also became a symbolic vector for the reformulation and enactment of ideas of popular power, community, nationhood, citizenship, social justice and political subjectivities.

However, I will also show how oil resources, transformed into money, became a key social signifier for the inherent difficulties in concretizing 
the ideals embodied in the Bolivarian revolution. Through focusing on imageries of consumption, individualism, corruption and greed, and the ways in which these were mediated through everyday political practices, I aim to tease out an underlying script of the ills and immoralities associated with Venezuela's history of extractive capitalism. Seen as a whole, this analysis illustrates how both the materiality and the imagery of oil have historically been ingrained into Venezuela's social, cultural and political body, and how this legacy informed, in very concrete ways, the everyday unfolding of grassroots politics and social policy in the Venezuelan barrios.

Ultimately, I argue, it is paramount to understanding this legacy, in its various dimensions, if we want to get a proper grasp of the challenges of concretizing the Bolivarian process' goal of deep political transformation through bottom-up participatory politics. Indeed, the key intervention in this book is that the confluence between Bolivarian ideals and politics on the one hand, and the social practices, cultural ideas and political dynamics inherited from the pre-Bolivarian era on the other hand, created deep tensions and hindrances for the unfolding of the goals of the Bolivarian process. Such a historicized bottom-up perspective on the "thick" processes shaping day-to-day dynamics within and outside formal political arenas are indispensable correctives to simplistic interpretations and characterizations of the Bolivarian process frequently circulating both in the global press and in the academic community.

\section{Everyday STATE-MAKING}

Scholars have increasingly turned their attention to how political struggles are grounded in everyday actions-lo cotidiano - in people's face-to-face interactions in their local spaces: markets, workplaces, neighborhoods and local social movements, and in their everyday encounters with state bureaucracy and political representatives (Nuijten 2003; Lazar 2008; Fernandes 2010). One of the anthropological novelties in studies of the state has exactly been to treat everyday practices as state-making in practice. Through numerous and seemingly mundane encounters, the state both manifests itself and naturalizes its presence and power, while the population simultaneously comes to learn, feel, comprehend and imagine what the state is. Because it is given for granted and removed from the political realm, everyday bureaucratic proceedings that every citizen must engage in - in one way or the other-are powerful windows into the naturalized and almost inescapable presence and effect of the state-and 
thus its power-in people's lives (see Foucault 1991; Gupta 1995; Blom Hansen and Stepputat 2001).

However, in this book, I will argue that community activists in Caracas to a large degree conceived of everyday encounters with the state as "state making in practice." Community politics constituted a series of negotiated encounters between popular sectors and state actors where people pushed and tested the resilience of a historically adversary state power, trying to shape a new state form responding to the ethos of poder popular (popular power) as articulated within the Bolivarian discourse. Often state bureaucracy was unresponsive and occasionally hostile, effectively opposing the creation of a state at the service of its citizens and subordinate to popular sovereignty. As I will show, las instituciones (the institutions) and la burocracia (the bureaucracy) constituted multi-layered templates embodying not only a historicized notion of the "degeneration of the state" during the political era prior to Chávez-often referred to as Puntofijismo or the Fourth Republic ${ }^{6}$ - but also a complex understanding of the internal incoherence and personalized rules of power permeating state bureaucracy. This emic perception of the state apparatus reflects the historical sociopolitical formation of the Venezuelan state and its various language of stateness (Blom Hansen and Stepputat 2001), providing both an obstacle and an opportunity for the popular sectors to carve out a space for themselves. In order to tease out these dimensions of both state transformation and state stasis, I will focus on the everyday encounters between popular sector activists and public officials, as well as the mundane activities in the barrios and the ways in which these were constituted as ways of assuming popular power. Drawing on Scott (1999), I will explore how the knowledges of the state and the knowledges of the grassroots were negotiated in everyday encounters, constituting a focal site for carving out a space for popular power within the languages of the state (Blom Hansen and Stepputat 2001) - and in extension of transforming the state itself.

However, I will suggest that just as much as local struggles were concretely grounded in claims to material vindication and political recognition, they can also be interpreted as attempts to find a new sense of moral community - a locally grounded form of ethical life (Lambek 2011). In his analysis of the Chávez government, Escobar suggests that:

Besides the policy level, it would be important to investigate the extent to which the processes under way have changed those imaginaries, representations, and desires of the population that became more deeply ingrained 
than ever during the neo-liberal decades-e.g. ideologies of individualism, consumerism, the "marketization" of citizenship and so forth. (Escobar 2010:9)

As I will demonstrate, the contradictory tensions that Escobar refers to played out on the arenas for social and political mobilization as an ethos toward re-founding the "collective" through community activism and participatory politics; an ethos that often clashed with social inclinations privileging individual gains and ambitions.

These locally enacted struggles formed part of a broader calling for creating a new Bolivarian society, drawing on a repertoire of contested imageries of the Venezuelan state at different historical conjunctures. People conceptualized both individual and collective action within the realm of the Bolivarian space as part of a deeper process of social transformation. Thus, people "lived" state-making through their everyday actions, which is, I will argue, part of the explanation of why the Bolivarian revolution attained such enormous affective and political appeal among the poor.

\section{Capturing Realities}

The scholarly community is deeply divided over how to characterize Chávez's time in government. While some argue that he presided over an authoritarian and undemocratic regime, others argue that he democratized Venezuelan society through expanding democratic participation and incorporating new social groups into the political domain. Roughly speaking, these divisions reflect disagreements between those who deploy a formal procedural model for liberal democracy as their yardstick (e.g., see McCoy and Myers 2004; Corrales and Penfold 2011), and those who argue that Chávez inspired a form of radical democracy that has to be assessed sui generis (see Ellner 2010; Smilde and Hellinger 2011; Azzelini 2013; Ciccariello-Maher 2016). Though this book is not concerned with judging how the Chávez government fared with regards to either of these models per se, my analytical approach concurs with the latter position. Overall, it will be clear that I do not find it analytically meaningful for the purpose of my ethnographic focus to apply pre-defined and frequently Euro-centric and elitist models and concepts onto complex realities defying simplistic assessments. Rather, I offer an historicized and contextualized analysis of the Bolivarian process through unpacking how political dynamics, state-society relations and social life in the Chávez era was 
shaped in the intersection between the country's historical legacy and emerging and evolving social, political and cultural formations.

Moreover, my long-term ethnographic experience in the field allows me to ground my analysis in a view on Venezuelan society "from below." As Lindisfarne notes: "Because anthropology pays attention to the lives of ordinary people, they see society from below. From there, power and privilege stand out in sharp relief" (Lindisfarne 2008:23, cited in Armbruster and Lærke 2008). In alignment with this assertion, this book is concerned with tracing the various ways in which different forms of power-be it epistemological, political, crude or structural-have shaped life in the Venezuelan barrios both in the past and in the present, and the creative and multi-faceted ways of resistance and contestation this has engendered. Concurrently, I seek to carve out a broad and complex understanding of processes of change and political struggle under the Chávez government, as experienced and conceptualized by the urban popular sectors in Caracas.

\section{LIFE IN THE BARRIO}

By now, the reader should have a fair idea about the analytical scope and ambition of this book. Hence, it is time to properly introduce the ethnographic field in which these analytical explorations are located in. Allow me to present a snapshot of a random but representative barrio in western Caracas:

You get off the crowded camioneta (small bus), decorated with plastic saints, plastic flowers and painted stencils, filled with school children, mothers holding their babies, housewives carrying grocery bags, whitecollar workers dressed in neatly ironed shirts, youngsters listening to music from their telephone, the rest of us forced to listen to whatever salsa, reggaeton or hip-hop tune the driver prefers. The camioneta has taken us from the main street, where we lined up waiting for the buses to fill and take off, up through the winding, potholed main road passing through various barrio neighborhoods, interspersed with some lower middle-class residential buildings.

Here in the Venezuelan barrios you find all the people who keep the wheels in Venezuelan society going; the brick-layers, the hairdressers, the 
waiters, the electricians, the cooks, the cleaners, the gardeners, the bus drivers, the taxi drivers, the construction workers, the shop attendants, the secretaries, the nannies, the informal vendors; indeed, the entire proletariat as well as precariat. You also find many lower-level government employees, bank clerks, teachers, nurses, police, soldiers, and not in the least, housewives who shoulder much of society's high costs for social and household reproduction.

On both sides of the road there are sprawling barrio houses built on top of each other, packed so closely together that it is almost impossible to distinguish one construction from the other. Some of them are half-built or abandoned-perhaps those who built them ran out of money or found luck somewhere else. ${ }^{7}$ Some of them have home-painted signs hanging on the wall announcing se vende (for sale). Others have a poster of Chávez hanging in the window facing the road. Here and there, some provisionally built stairways or passages lead into the barrio, continuing up the hill. It is impossible to see how far up the community goes, as the buildings along the road, often reaching three or four stories, block the view. All you see is an impressive organic mass defying gravity. Most of the houses have grids in front of their open window frames, where laundry is left to dry.

Along the road, on the ground floor, various bodegas (small shops) are selling everyday basics—candy, sodas and juice, mobile telephone refill cards, canned tuna, single rolls of toilet paper. The bodegas mostly have a grid between the customer and the vendor, and most shops have a sign outside saying something like no se fia (no credit). Often, friends and neighbors hang out outside gossiping with the shop owner.

The roadside is dotted by outdoor garages, where greasy men with bare chests are repairing crumbling cars that have been repaired hundred times before. These men are more likely than others to whistle at girls passing by or to make indecent comments. On weekends, they often have a beer while working, and younger boys hang around getting introduced to the men's world. The sidewalks along the streets are often falling apart, suffering from a lack of maintenance and frequent remakings because pipe systems need to be repaired or extended, or new families try to tap into them. Plastic tables frequently line the sidewalks, offering mobile phones for rent, charging by the minute. These stalls also sell chewing gum, candy and single cigarettes, and sometimes home-baked cakes wrapped in plastic. Or, alternatively, pirated DVDs or lottery tickets.

It is often young girls working at these stalls, text-messaging friends, boyfriends and potential boyfriends, picking at their neatly painted acrylic nails, chatting and gossiping with friends and neighbors. Their hair, 
clothes and makeup are immaculate. Venezuela is renowned for its women, though the women who win Miss Universe and Miss World are upper-class women of European descent who have spent years in beauty schools and a fortune on plastic surgery. The girls in the barrios are shorter, darker and with more curves, radiating a street-smart air and awareness of their body - a result of having grown up in a society where little girls are socialized into becoming sexual objects before they have even started primary school. ${ }^{8}$ Many of the barrio girls become pregnant while still in their adolescence. They carry their "adorned" babies on the bus, on the metro, and through barrio streets looking like what they are: a child carrying a child. The father may be the skinny local teenage boy who hangs out at the corner, mobile phone in hand, expensive sporting clothes, watching the girls from a distance, a true "street corner society" with complex social rules and crushing demands for upholding masculine pride. In the evenings, weekends or holidays, the boys might be drinking beer, or collectively repairing an old car or a motorbike.

The neighborhood's skinny alcoholics, crack addicts and near-crazy people hang out on the corner as well, or perhaps sit on the ground next to an electricity pole. They greet passersby and are as much a part of street life as anyone else, feeding their habits and otherwise surviving by taking small jobs in the neighborhood, like carrying bags of sand for cement, gas tanks, or bricks, or basically any small job that can be found.

Housewives and the elderly also walk along the narrow sidewalk, quickly picking up something from the bodega and stopping for a chat, sometimes dressed in nightgowns or comfortable clothes. There may be children accompanying them or they might have a child in their arms. In general, there are children everywhere, quickly passing by in their black-and-blue school uniform, or hanging out in the street with a parent who has a business close by, or on their own, socialized to the adults' world all too early. The way they talk, how they move, how they carry their body, their eyesit all reveals that their innocence is long gone, if it ever was there.

Street dogs, also part of the urban landscape, roam through the garbage, sad-looking mixed breeds, often with a limp, a cut, or half an ear torn off after surviving a dog-eats-dog fight. Pieces of garbage and litter are everywhere-paper, plastic cans, empty soda bottles, empty bags of fries and candy, half-eaten food. Once in a while a community brigade cleans the open sewers, the pavements, the sidewalks, the hillside, which invariably become littered again soon. The smell of garbage mixes with the smell of sewage, urine, gasoline, dust and food, creating a greasy air that covers your skin with a thin, black film. 
Along the road is a basketball field, set up by the communal council, where the local boys shout, listen to music and play basketball while looking at girls walking by or gossiping with some of them. Girls often hang around the basketball field in groups, alternating between posing for and quarreling with the boys in teenager's way. These girls will often be talked about by their neighbors. Their reputation can easily be tarnished even before they appear with a growing belly. There is probably a Barrio Adentro module along the main street - the characteristic octagonal Cuban medical station, with an office on the first floor and the doctor's apartment on the second. A hand-written note announces its opening hours. A lot of hand-written notes are also pegged to the walls of private homes, selling cakes, yogurt, vegetables, cigarettes, gelatin, or offering nail, hair or makeup services, repair of domestic items or whatever other entrepreneurial activities its residents have come up with to make some extra money.

By eight or nine o'clock at the latest, most barrio streets start becoming more and more deserted. Violence and insecurity have caused most "ordinary people" to stay inside their homes late in the evening and at night, unless they have to come home late from work. This has led to less "ordinary people" mingling in the street, and turning public and common spaces into areas considered even more unsafe. Imagined or not, the streets are considered the unruly and hazardous realm of el hampa (the street delinquents) at night. Fenced off by locks and metal grids, people gather in their small ranchos (barrio homes) and apartments, eating a late evening dinner or snack, talking, and watching TV. Except for the occasional barking dog, gunshot, noisy muffler or muffled music, the barrios are surprisingly silent at night during weekdays. Its inhabitants have a long and exhausting day of work, studies and household chores waiting for them the next day.

\section{UNBOUNDED BARRIOS}

This snapshot serves as an introduction to the barrios of Caracas, my site of ethnographic research during the past 12 years. Since 2005, I have gone back and forth to Venezuela eight times, spending altogether almost two years in the country. For the most part I have been living in either the parish of 23 de Enero or in the hilltop barrio of Casalta 3 above the com- 
mercial- and residential hub known as Propatria. In many ways Venezuela has become my second homeland: in the course of these years, I married a Venezuelan, got an extended family-in-law spread across Caracas and indeed Venezuela, and gave birth to a daughter that is half-Venezuelan.

During the field visits when I lived in 23 de Enero, I rented a small room in an apartment close to the metro station known as Agua Salud. Here, I shared a flat with Ernesto, a journalist and revolutionary native of 23 de Enero in his early 60s, his blind poodle Beethoven, and his cat Amarilla (and later her four, non-toilet-trained kittens). Later, I moved to Casalta 3, where I lived with my extended family-in-law in a large, typical barrio dwelling that had been constructed and gradually expanded over the last 40 years as the family grew.

These different living arrangements provided me with a broad platform for getting to know Venezuela's barrios from the inside. Living with Ernesto was an invaluable inroad into getting to know people in 23 de Enero, and I learned a lot from his stories about the community's

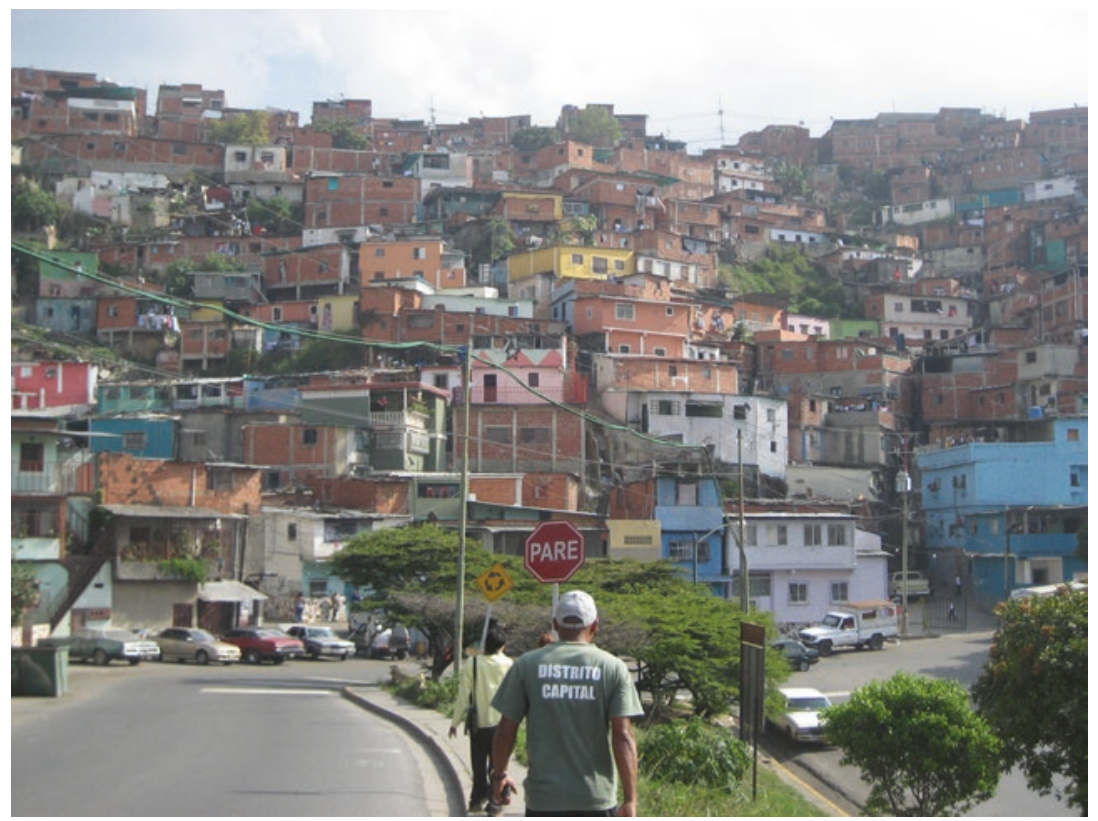

Photo 1.1 The parish of 23 de Enero. Photo by the author 
history-and his engagement with it-for the past 60 years. Moving to Casalta 3, however, gave me a contrasting experience to that from 23 de Enero, which is a very emblematic barrio with a set of very particular characteristics. The area surrounding Propatria had a different social and demographic profile and a different social and political history, and gave me new insights into the heterogeneity-yet also similarities-that exists between different barrios. Second, living with an extended family also provided a space for me to get to know Venezuela much more from "the inside," providing me with detailed knowledge of social life, family dynamics, and the nitty-gritty details of everyday practicalities.

However, throughout all my field visits, I have been regularly visiting and traveling to other barrios in western Caracas. The purpose of this methodology was that I didn't want to confine myself to one barrio com-

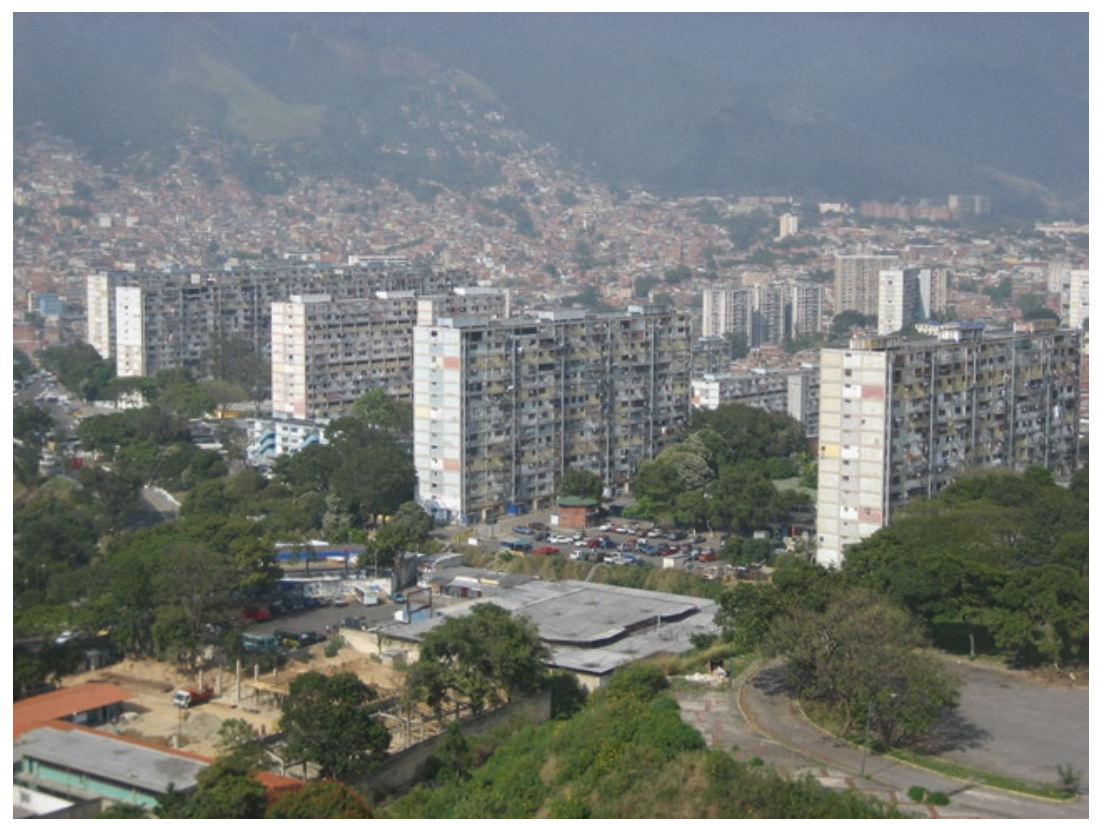

Photo 1.2 Some of the famous superbloques (apartment buildings) of $23 \mathrm{de}$ Enero with the barrio la Pastora and the mountain ridge Ávila in the background. Photo by the author 
munity. As you settle in a barrio community, you become acquainted with people who want to bring you to their area and to attend events or meetings in other parts of the city. Community activism fomented new and very fluid social networks and meeting arenas both within and among barrios. Thus, drawing an analytical circle around "my community" would have been both limiting and reifying. As Fernandes also notes in her study of social movements in western Caracas: "As I moved among the barrios of Caracas, I realized that these worlds within the shantytowns were an interconnected whole, and selecting one research site would be an artificial enterprise" (Fernandes 2010:30).

Moreover, my quest for understanding the Bolivarian process as a dynamic interaction between shantytown communities and the state in a broader perspective also required that I explored political change and social transformations beyond the socio-territorial confines of the barrios. To that end, I went to all sorts of public and political events and venues. I participated in mass gatherings with Chávez and military parades, sat in on committee meetings of the National Assembly, visited PDVSA headquarters, was in doubt about who is interviewing whom in the intelligence unit of the vice-presidency, lingered in the waiting area of the mayor's office and in lunch box queues waiting for ministers and other high-level officials. I chatted with state bureaucrats, studied public documents, was accidentally locked up in the national assembly office building after closing hours (a guard eventually came to my rescue) and visited public shelters for the homeless after the 2011 torrential rains. I have also twice roadtripped across Venezuela, visiting 20 of the country's 23 states and meeting up with community activists in other parts of the country. And finally, on the back of a moped I traveled from Caracas to the remote rural village known as Llora Llora ("Cry Cry") in the state of Guarico (allegedly constituting the center point of the country), making me intimately acquainted with the country's many potholed roads in a manner that my buttocks will never forget.

But most of all I delved into the barrios of western Caracas, spending liters of sweat climbing the arduous barrio hills, and fared up and down its main roads in camionetas. I participated in numerous community assemblies and community groups meetings, "hung around" talking to people, and inspected a variety of community projects accompanied by both local activists and public officials. 


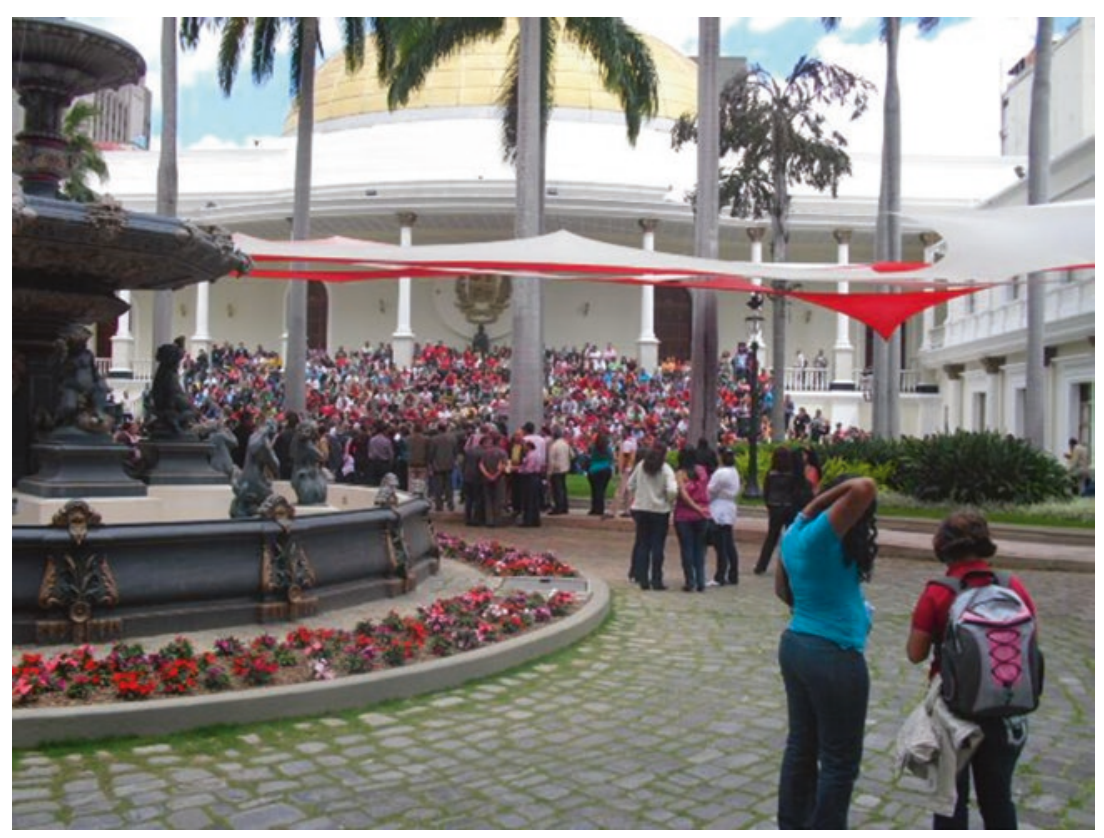

Photo 1.3 Public meeting about the communal councils in the National Assembly. Photo by the author

\section{EVERYDAY BARRIO LIFE}

Living in a barrio was an indispensable tool for understanding local life worlds and the deeper meaning of political struggle from below. Though naturally shielded by having more money at my disposal than local residents, I physically felt the inherent challenges of living in a barrio. That was not only related to the unstable and interrupted supplies of water, the strenuous task of buying food and household items and the problems with garbage collection and public transport, but I also witnessed the social problems generated by decades of accumulated poverty up close. The threat of crime and violence was a factor that structured my everyday life, and the (often related) hidden and visible consequences of alcohol and drug ( $\mathrm{ab}$ )use evidenced the deeply rooted social problems that the processes of social struggle were seeking to reverse. Twice, I ducked because shooting broke out nearby, and on several occasions people were killed in the street in places where I used to spend my time or pass by. 


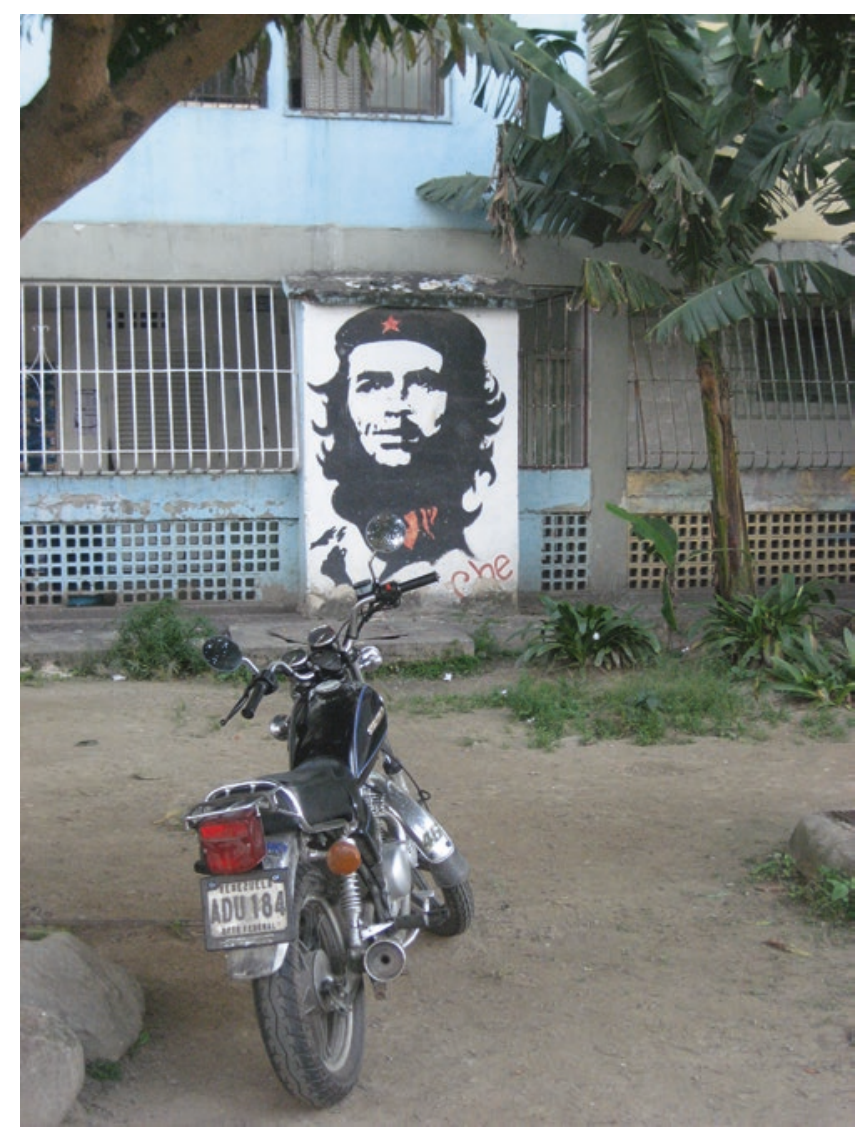

Photo 1.4 Mural of Che Guevara, 23 de Enero. Photo by the author

At the same time, living in a barrio was also a powerful antidote to the tendency of scholars, media commentators and middle- and upperclass Venezuelans to portray the barrios as "no-go" areas; as a social anomaly in a constant state of emergency. Life in the barrio has many characteristics that I deeply appreciate. It is filled with energy, informality, friendliness, humor and generosity, and everyday life goes on as it does anywhere else. As I explore in Chap. 3, the barrios are composed by social micro-landscapes, where people's engagement with their surroundings is structured by social relationships, local histories and spatially embodied 


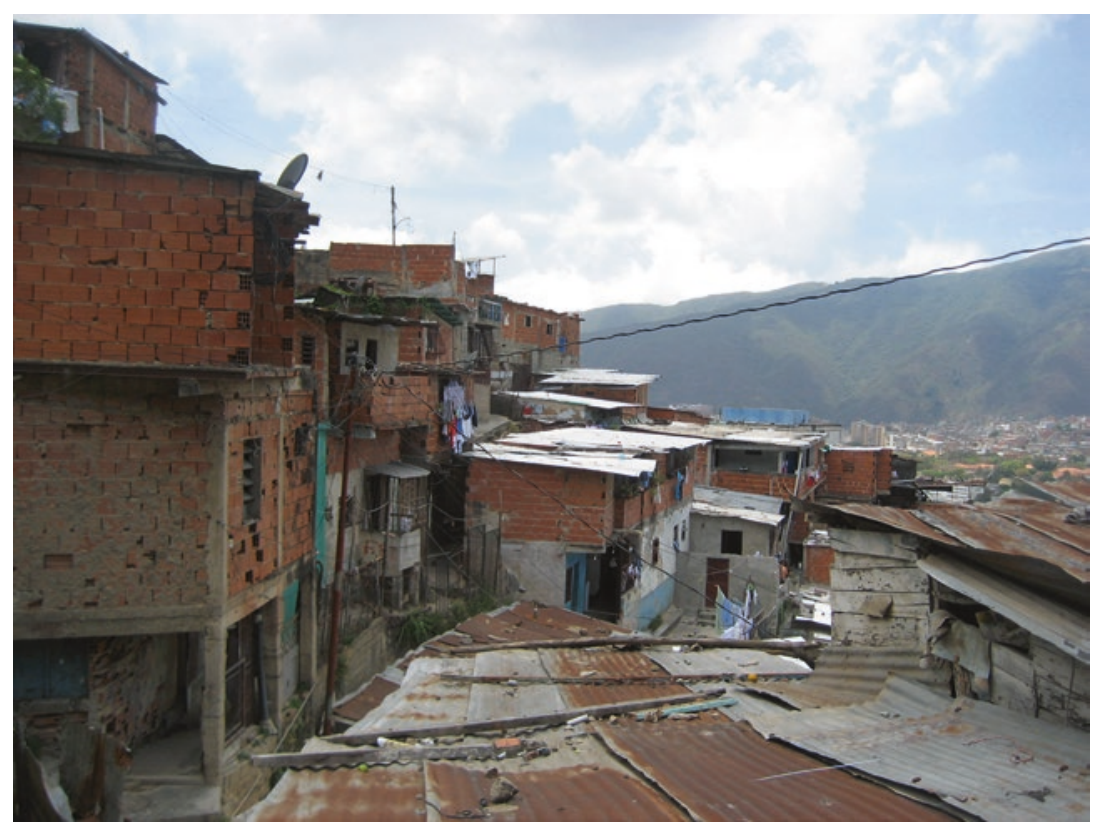

Photo 1.5 Barrio houses, 23 de Enero. Photo by the author

knowledge. As my research field also became my temporary home, I too found "my" place in the social landscape. Joining the local boxing club, drinking beer in the local backyard bar, attending popular religious celebrations, chatting with my working-from-home manicurist, eating at local food joints and participating in women's gossiping around the kitchen table over a bottle of sweet liquor constituted a central part of my ethnographic engagement with Caracas.

\section{STRUCTURE OF THE BOOK}

This remaining part of this book is divided into nine chapters, followed by a conclusion. In Chap. 2, I offer a reading of Venezuelan history that frames the analysis and arguments pursued in the rest of the book. In this chapter, I will pay particular attention to Venezuela's development trajectory as an oil state, and how this shaped key political dynamics in the 
Puntofijo era. Chapter 3 seeks to shed light on the history of grassroots organization and popular sector struggle that preceded and paved the way for Chávez's electoral success, followed by an exploration of people's experiences and memories from the Puntofijo era in the form of poverty, marginalization and state violence. Chapter 4 draws linkages between different forms of spatial, economic and social segregation that have shaped Venezuelan society, and shows how these divisions played out in the context of political polarization in the Chávez era. Toward the end of the chapter, I focus on people's own explanations for their support for Chávez and the Bolivarian process. Chapter 5 begins the exploration of community politics through focusing on how popular sector communities established themselves as political actors vis-à-vis the state through the idiom of poder popular. At the same time, it sheds light on the heterogeneity of popular sector communities, and how this is played out in local power struggles. These dynamics are teased out through a close examination of a case study depicting the mobilization around the building of a new hospital in 23 de Enero. Chapter 6 brings us on the inside of the Venezuelan state, as I critically discuss how the internal dynamics, institutionalized structures and heterogeneous actors within the Venezuelan state apparatus shaped the unfolding of the Bolivarian process. This discussion prepares the ground for Chap. 7, where I examine the interface between the Venezuelan state and popular sector communities through focusing on the so-called promotores integrales-lower-level public employees who assist community organizations that receive funds from the state. In this chapter, I also discuss how different forms of knowledges - that of the state and that of the popular communities-are negotiated in the context of community politics, and how social and political hierarchies between state officials and popular sector activists are challenged and mediated in Bolivarian discourse. In Chap. 8, I will explore how the social dimensions of Venezuela's historical legacy as an extractive state is articulated through discourses and practices within the Bolivarian space. In particular, we will tease out how templates revolving around oil wealth, money and consumption emerge as social critique of capitalism's and neoliberalism's harmful effect upon society. I will also show how these templates gain salience as potent social signifiers in the ideological and political polarization between supporters and opponents of the Bolivarian process, and how these can be linked to global templates associated with modernity and development. In Chap. 9, I turn to the issue of collective consumption in 
the form of social spending during the Chávez era. I will examine how the historical political culture of state paternalism and strategic clientelism was both contested and reproduced, and how social spending produced at times ambivalent notions of "deserving" and "undeserving" recipient of oil wealth. In Chap. 10, I will turn to the issue of corruption. I will seek to illuminate corruption's historical meaning and origin in the light of Venezuela's historical trajectories as a post-colonial extractive state, and its role as a dense social signifier and as a social practice in the context of community politics. In the final chapter, I offer a synthesized analysis of the different foci and lines of investigation pursued throughout the book, before I reflect upon what the Venezuelan case can tell us about the promises and perils of oil wealth, as well as political, ecological and social challenges characterizing the contemporary state of the world more broadly.

\section{Notes}

1. Note that voting patterns in favor of the Chávez government were not consistently class-based as he also drew significant support from the middle class (see Lupu 2010). However, this book is solely focusing on the relationship between popular sector citizens and the Chávez government.

2. By the term "popular sectors," I am, in the context of this book, referring to the part of the urban population living in lower-income housing areas, or informal shantytown settlements. It is important to note that this term does not only refer to a socio-economic stratum but also refer to an imagined community (Anderson 1983), "the poor," depending on context. Similarly, el pueblo constitutes a multi-faceted and multi-layered term in Spanish, meaning village/rural town or people/popular classes, or a combination of both, depending on the context (Nugent 1993:34). In political Bolivarian discourse it commonly refers to "the poor" or the popular sectors, having an implicit historical reference to oppression and marginalization.

3. In 2005, at the fifth annual gathering of the World Social Forum in Porto Alegre, Brazil, in front of a crowd of 15,000 people, Chávez declared himself a socialist. He also made it clear that in his view the way forward was not the dogmatic socialism of the past, but a gradual search for what he called "Socialism for the twenty-first century."

4. "Populist" is one of the milder characteristics. The US media in particular used a strong language to describe him. Adjectives used include "would-be dictator," "authoritarian ruler," "autocrat," "petro-dictator," "indomitable strongman," "brutal neo-authoritarian," "warmonger," and "caudillo" (see Bhatt 2014). 
5. Theoretically, he weaves together "theories of underdevelopment, neoclassical views of natural resources, the Marxist theory of value and an analysis of the evolution of oil prices in this century" (Coronil 1997:6) as well as modernization and subalternity theories, seeking to "unsettle the illusion that [Venezuela's] history can be contained within fixed theoretical, temporal, or cultural boundaries" (Coronil 1997:xi).

6. The term "Puntofijo" refers to a political pact (the pact of Punto Fijo, from the place where it was signed) between the two dominant parties, Accion Democrática (Social Democrats) and COPEI (Christian Democrats). It was signed in 1959, and lasted until 1998 when Chávez came to power. The Puntofijo era or puntofijismo is interchangeably referred to as the Fourth Republic and its powerholders are referred to as cuartarepublicanos (fourth republicans).

7. Over time, most barrio dwellers manage to gradually build up a house made of brick and zinc, but a total of 13,610 homes in Caracas and Greater Caracas were classified as ranchos in the 2011 national census, defined as a construction built with waste materials, such as wooden boards, cartons and so on (Universidad de los Andes n.d.).

8. A five-year-old girl I know dressed in a mini-skirt looks at her behind in the mirror and says: "I have to continue with my swimming lessons; it gives me nice thighs and lifts my buttocks."

\section{BIBLIOGRAPHY}

Anderson, Benedict. 1983. Imagined Communities: Reflections on the Origin and Spread of Nationalism. London: Verso.

Azzelini, Dario. 2013. The Communal State: Communal Councis, Communes and Workplace Democracy. NACLA 46 (2): 25-30.

Bhatt, Keane. 2014 [2013]. The New York Times on Venezuela and Honduras: A Case of Journalistic Misconduct. NACLA, May 8. https://nacla.org/article/ new-york-times-venezuela-and-honduras-case-journalistic-misconduct. Accessed February 20, 2017.

Ciccariello-Maher, George. 2013. We Created Chávez: A People's History of the Venezuelan Revolution. Durham and London: Duke University Press.

. 2016. Building the Commune. Radical Democracy in Venezuela. London and New York: Verso.

Collier, Paul, and Anke Hoeffler. 1998. On Economic Causes of Civil War. Oxford Economic Papers 50 (4): 563-573.

- 2000. Greed and Grievances in Civil War. Washington, DC: World Bank, Development Research Group. 
2005. Resource Rents, Governance, and Conflict. The Journal of Conflict Resolution 49 (4): 625-633.

Coronil, Fernando. 1997. The Magical State: Nature, Money, and Modernity in Venezuela. Chicago: University of Chicago Press.

Corrales, Javier, and Michael Penfold. 2011. Dragon in the Tropics. Hugo Chávez and the Political Economy of Revolution in Venezuela. Washington, DC: Brookings Institution Press.

Ellner, Steve. 2010. Rethinking Venezuelan Politics. Class, Conflict, and the Chávez Phenomenon. Boulder and London: Lynne Rienner Publishers.

Escobar, Arturo. 2010. Latin America at a Crossroad. Cultural Studies 24 (1): $1-65$.

Fernandes, Sujatha. 2010. Who Can Stop the Drums? Urban Social Movements in Chávez' Venezuela. Durham and London: Duke University Press.

Foucault, Michel. 1991. Governmentality. In The Anthropology of the State. A Reader, ed. A. Sharma and A. Gupta. Oxford: Blackwell Publishing.

Fukuyama, Francis. 1992. The End of History and the Last Man. New York, London, Toronto, Sydney: Free Press.

Gledhill, John. 2000. Getting New Bearings in the Labyrinth: The Transformation of the Mexican State and the Real Chiapas. Lecture manuscript, Department of Social Anthropology, University of Manchester.

Gupta, Akhil. 1995. Blurred Boundaries: The Discourse of Corruption, the Culture of Politics, and the Imagined State. In The Anthropology of the State. A Reader, ed. A. Sharma and A. Gupta. Oxford: Blackwell Publishing.

Hansen, Thomas Blom, and Finn Stepputat. 2001. Introduction: States of Imagination. In States of Imagination. Ethnographic Explorations of the Postcolonial State, ed. T.B. Hansen and F. Stepputat. Durham and London: Duke University Press.

Karl, Terry Lynn. 1997. The Paradox of Plenty. Oil Booms and Petro-States. Berkeley: University of California Press.

Lambek, Michael. 2011. Catching the Local. Anthropological Theory 11 (2): 197-221.

Lazar, Sian. 2008. El Alto, Rebel City. Self and Citizenship in Andean Bolivia. Durham and London: Duke University Press.

Lindisfarne, Nancy. 2008. Starting from Below. Fieldwork, Gender and Imperialism Now. In Taking Sides. Ethics, Politics and Fieldwork in Anthropology, ed. H. Armbruster and A. Lærke. New York and Oxford: Berghahn Books.

Logan, Owen, and John-Andrew McNeish. 2012. Rethinking Responsibility and Governance in Resource Extraction. In Flammable Societies. Studies on the Socio-economics of Oil and Gas, ed. J.-A. McNeish and O. Logan. London: Pluto Press.

Lupu, Noam. 2010. Who Votes for "Chavismo"? Class Voting in Hugo Chávez's Venezuela. Latin American Research Review 45 (1): 7-32. 
McCoy, Jennifer L., and David J. Myers. 2004. The Unraveling of Representative Democracy in Venezuela. Baltimore and London: The Johns Hopkins University Press.

Mommer, Bernhard. 1996. Integrating the Oil: A Structural Analysis of Petroleum in the Venezuelan Economy. Latin American Perspectives 23 (3): 132-158.

- 2004. Subversive Oil. In Venezuelan Politics in the Chávez Era: Class, Polarization, and Conflict, ed. S. Ellner and D. Hellinger. Boulder and London: Lynne Rienner Publishers.

Nugent, Daniel. 1993. Spent Cartridges of Revolution. An Anthropological History of Namiquipa, Chibuahua. Chicago and London: The University of Chicago Press.

Nuijten, Monique. 2003. Power, Community, and the State. The Political Anthropology of Organization in Mexico. London and Sterling, VA: Pluto Press.

Pérez Alfonzo, Juan Pablo. 2011 [1976]. Hundiéndonos en el excremento del diablo. Caracas: Banco Central de Venezuela.

Rogers, Douglas. 2015. Oil and Anthropology. Annual Review of Anthropology 44: 365-380.

Rosser, Andrew. 2006. Escaping the Resource Curse. New Political Economy 11 (4): 557-570.

Sachs, Jeffrey D., and Andrew Warner. 1995. Natural Resource Abundance and Economic Growth. Working Paper 5398, National Bureau of Economic Research and Harvard University, Cambridge, MA.

- 2001. The Curse of Natural Resources. European Economic Review 45 (4-6): 827-838.

Salas, Miguel Tinker. 2009. The Enduring Legacy. Oil, Culture, and Society in Venezuela. Durham and London: Duke University Press.

Scott, James. 1999. Seeing Like a State: How Certain Schemes to Improve the Human Condition Have Failed. New Haven and London: Yale University Press.

Smilde, David, and Daniel Hellinger. 2011. Venezuela's Bolivarian Democracy. Participation, Politics, and Culture under Chávez. Durham and London: Duke University Press.

Universidad de los Andes, Venezuela. n.d. Conceptos y definiciones de población y vivienda. http://iies.faces.ula.ve/censo90/Conceptos_definiciones_de_poblaci\% C3\%B3n_vivienda.html. Accessed February 20, 2017.

Valencia, Cristobal. 2015. We Are the State! Barrio Activism in Venezuela's Bolivarian Revolution. Tucson: The University of Arizona Press. 
Open Access This chapter is distributed under the terms of the Creative Commons Attribution 4.0 International License (http://creativecommons.org/ licenses/by/4.0/), which permits use, duplication, adaptation, distribution and reproduction in any medium or format, as long as you give appropriate credit to the original author(s) and the source, provide a link to the Creative Commons license and indicate if changes were made.

The images or other third party material in this chapter are included in the chapter's Creative Commons license, unless indicated otherwise in a credit line to the material. If material is not included in the chapter's Creative Commons license and your intended use is not permitted by statutory regulation or exceeds the permitted use, you will need to obtain permission directly from the copyright holder. 


\section{A History Written with Oil}

In the words of the Venezuelan intellectual and politician Domingo Alberto Rangel, "no event in Venezuela can be separated from oil ... It is the fundamental force that shapes national life. All aspects of the Venezuelan economy are the legitimate or bastard children of that substance that irrevocably stained our history" (cited in Tinker Salas 2009:2). In July 1914, Zumaque 1, Venezuela's first oil well, was put in production in Mene Grande in the state of Zulia. By 1928, Venezuela was the largest oil exporter in the world (Grisanti n.d.). These first decades of the twentieth century constituted an important period of transition in Venezuelan history. In Hillman's words, Venezuela went from a state of "caudillistic anarchy to a status of peripheral dependency" (Hillman 1994:34). Oil was a key component in this process. It attracted foreign oil companies to the country and shaped the formation of a nominally "modern" state and its economic base. It shaped Venezuela's relation to foreign, primarily North American business interests, and the country's relation to the global economy. It shaped the formation of different social groups and political alliances within Venezuela, as well as, with time, patterns of migration and the abandonment of the countryside, of rapid and uncontrolled urbanization, and of underdeveloped labor markets. It also shaped patterns of class formation, and the country's exposure to North American cultural models and values (Tinker Salas 2009). Indeed, oil was a transformative agent in Venezuelan society. In a relatively short time it metamorphosed the country from being a coffee-exporting and geopolitically quite insignificant 
country, still caught up in its post-colonial internal power struggles and correspondingly weak state structures, into becoming a putative petrostate (Karl 1997) and a hub for international extractive industries and global commodity flows.

These patterns and processes are of deep contextual significance for our subsequent analysis of twenty-first-century Venezuela. In particular, I want to highlight three important aspects. One is the ways in which the transition from dictatorship to electoral democracy was premised upon the consolidation of a political system that centralized access to political power and the benefits of the country's oil revenues in the middle- and upper classes, creating a deeply socially segregated society. As we follow the unfolding of this story in the period 1960-1998, some events and trajectories that would later become of potent political, social and cultural significance in the Chávez era are highlighted.

The other aspect that I will bring attention to is the United States' strong presence in the country through the oil industry, and how this influenced the ways in which consumer culture and class identities were shaped among the Venezuelan middle- and upper classes. As we will discuss more in depth later on, this dimension of Venezuelan society is important for understanding how political ideologies, social identities and national(ist) sentiments were shaped in the Chávez era.

The third aspect that I want to bring attention to is of a subtle nature, namely how Venezuela's formation as a state and a society is intertwined with the country's uneven amalgamation into global geopolitics and global capitalist markets. Amalgamation, because as an oil-exporting country it was central to the flow of black gold so vital to global capitalist development. And uneven, because as a post-colonial, semi-peripheral, oil-exporting country, its political and economic processes have been intrinsically connected to political and economic forces beyond its control. These processes have brought cycles and patterns of social and political conflict and full-blown crisis.

As the country now is passing through a phase of great difficulties, I believe there is a lesson to be learned here, as well as a question to be asked: why has it been so difficult for Venezuela to find a solid economic, political and social platform for its societal development? What are the underlying causes for the country's continuous conflictive and contradictive search for a political future? The rest of the book will seek to provide some answers to those questions, but first we need a solid understanding of where the Venezuela of today is coming from. 


\section{Gomez's Rule}

Venezuela gained independence from Spain in 1811 under the leadership of the national hero and icon Simón Bolívar. The ensuing decades were characterized by violent clashes between the Republicans and the Royalists, which escalated into the bloody three-years Federal Wars in 1858. After the war ended, the country continued to be characterized by caudillo rivalries and caudillo rule, a weak economy, abysmal living conditions for the common man and woman (Ewell 1984:19), and nascent attempts of nation building.

The first drop of oil was extracted from Venezuelan soil during the reign of Juan Vicente Gómez, who ruled the country in various periods between 1908 and 1935. Under Gomez's rule, Venezuela stepped into the era of industrialization and increased political centralization. Gomez personally negotiated concessions and terms with foreign oil companies (Ewell 1984:57). By 1922, he had built a national administration that was stronger and more unified than anything that had existed in Venezuela since the colonial period (Ewell 1984:59). Thus, to put it simply, the Venezuelan state took form through the establishment of the oil industry, and as Tinker Salas notes, "during the Gómez era the foreign oil industry and the Venezuelan state became inextricable" (Tinker Salas 2009:2).

Gomez's rule created significant opposition, conflicts and discontent in Venezuelan society outside of the limited circles that benefited from his regime - the army, the landed oligarchy, emerging economic elites, the church, foreign oil companies, and his loyal family and friends (Ewell 1984:59). Power struggles between old and emerging power factors carved out new political and economic faultlines. New political, ideological and artistic ideas inspired by European intellectual currents started to gain foothold, at the same time as Gomez's regime drove many intellectuals and artists into exile (Ewell 1984:48-50). Significant social unrest, including a series of anti-government protests at the Universidad Central de Venezuela (UCV) in 1928, was violently clamped down on and spurred the formation of a new generation of political leaders. Among them were Rómulo Betancourt, Raúl Leoni and Jóvito Villalba (Hillman 1994:35); two of them would later become presidents.

\section{EL TRIEnIO: 1945-1948}

Several factions and transitory parties were formed in the years that followed, but it was eventually Acción Democrática that stood out as the victorious party. Not only did it boast important national intellectuals 
and politicians on its side, such as Rómulo Gallegos and Andrés Eloy Blanco, but it also successfully managed to tap into the campesino population and gain the upper hand with the worker movements, weakening the Communists (Ewell 1984:91-92). Many middle-class professionals also gathered behind the party, carefully distancing themselves from communism as well as fiercely opposing the gomecistas (Ewell 1984:91-92). The seeds for a multi-class, but not a class-based party, were sown.

Gómez died in 1935 and was succeeded by General Eleazar López (1936-1941) and General Isaías Medina Angarita (1941-1945). Growing discontent and rigged elections in 1940 led to a coup against Medina in 1945, organized by Acción Democrática and young army officers.

Rómulo Betancourt, from Acción Democrática, headed the new governing junta. During the three years that they stayed in power-called el trienio - the junta wrote a new constitution, implemented a new petroleum law (Hillman 1994:36) and extended suffrage to all citizens above 18 years of age, including women and illiterates (Ewell 1984:97). Moreover, collective bargaining was introduced for the first time. Adeco cadres (members of Acción Democrática) tirelessly visited neighborhoods and municipalities, facilitating party organization and reaching half a million party members in 1948 (Ewell 1984:99).

However, the junta failed to be considered as legitimate mitigators between diverse claims and interests emerging from the church, the military, militant political party activities as well as the Christian-conservative COPEI, the other dominant party (Hillman 1994:36). In 1947, Rómulo Gallegos was elected president for Acción Democrática. Shortly thereafter, the military carried out a coup.

\section{The Rule of Marcos Pérez Jiménez}

The rule of General Marcos Pérez Jiménez lasted until 1958. Pérez Jiménez was accused of widespread corruption and of favoring himself and his allies. He banned opposition parties, closed the UCV and jailed and tortured opponents. But he also presided over a significant leap in industrialization, infrastructural developments and the promotion of sports and culture (Ewell 1984:108; see Derham 2010 for a re-reading of Pérez Jiménez's rule). As a consequence of the increased economic activity in the country, the non-petroleum share of GDP increased significantly, as did commerce and services (Ewell 1984:111). In 1955-1956, Pérez Jiménez's government negotiated a new set of petroleum concessions, 
seeking a way to ensure fresh revenues for its ambitious projects (Ewell 1984:110).

During his regime, urbanization processes accelerated, the immigration rate expanded, birth rates went up and life expectancy increased, and a media market of film, TV, press and radio took shape. These years also transformed the social life and values of the Venezuelan population. Many of the movies, TV-shows and magazines consumed in Venezuela were North American productions (Ewell 1984:113-114). A growing and prosperous middle class looked to Europe and North America in search of new identities. Christian Dior and Yves Saint-Laurent opened shops in Venezuela in the 1950s. The number of cars in the streets skyrocketed, so did the consumption of Scotch whiskey and champagne (Ewell 1984:117). Bars and nightclubs, not to mention brothels, rocked the Caracas night life (Ewell 1984:115-117). In short, Venezuela, at least urban Venezuela, was a booming country with political censorship.

Public conflict levels were low during large parts of the Pérez Jiménez regime. The clandestine parties kept a low profile, and the relative prosperity maintained popular discontent under control, even among the peasants and the working class (Ewell 1984:118). However, from 1957, tensions started to intensify. Commerce and business sectors, the working class and even the military started to feel excluded by different aspects of Pérez Jiménez's style of governance (Ewell 1984:119). An announced plebiscite over Pérez Jiménez's rule, designed to make him win, provoked the anger of the public. A failed military conspiracy against him on January 1,1958 , alerted civilian leaders of the high levels of dissatisfaction in military circles. Civilian political leaders had been clandestinely organizing and mobilizing for a long time, and now the time for action had come. Under the banner Junta Patriótica, they called for a general strike on January 21, and a popular uprising followed. On January 23, 1958, Pérez Jiménez fled the country.

\section{8-1998: A Pacted Democracy}

When Rómulo Betancourt once again assumed the presidency in 1959 , this time through democratic elections, the political game had largely already been determined. Prior to the elections in 1958, all presidential candidates has signed the interparty agreements Pacto de Punto Fijo (Pact of Punto Fijo) and the Declaración de Principios y Programa Minimo de Gobierno (Declaration of Principles and Basic Program for Government) 
(Karl 1997:82). In these documents, all the signatories committed themselves to pursue the same political and economic policies, regardless of the electoral outcome. Moreover, the Pact of Punto Fijo ensured that in future elections, each party would be guaranteed a piece of the pie, regardless of the electoral outcome, in the form of state jobs and contracts, control over ministries, as well as political positions granted through a complicated spoils system (Karl 1997:83).

The Programa Mínimo established that development would be pursued through the accumulation of foreign and private capital, and the private sector would receive subsidies and protection in order for it to prosper. Expropriation and socialization of property were ruled out, and land reforms were to be accompanied by compensation. Nationalization of the oil sector was also ruled out and the continued presence of multinational companies was guaranteed (Karl 1997:84). This implied a radical shift from Acción Democrática's previous nationalistic and anti-imperialist stance (Herrera Campins 1978, cited in Karl 1997:84).

\section{Locking the Political Game}

In the new constitution approved in 1961, presidential powers were greatly expanded. This granted Betancourt the authority over all significant public bodies, along with the power to name cabinet ministers, state governors and state enterprise officials (Karl 1997:83). A non-reelection clause was included, that in time would contribute to the lack of accountability of those installed in office (Karl 1997:84). The powers of congress were reduced by containing political competition, creating a system that left little room for challenging the executive (Karl 1997:84).

Karl defines the design of these arrangements as "the right to rule for the right to make money" (Karl 1997:85). In essence, Acción Democrática carved out a political model design to lock the political game to their benefit and secure control over the state apparatus, in exchange for guarantees to the business sector. The model also guaranteed that the interests of foreign business sectors, the church, the military and the ascending middle class were secured. Those who didn't have access to the party machine via client organizations, such as unorganized peasants or unskilled urban workers, were effectively shut out from the clientelist system. Labor and peasant groups were incorporated in the party-dominated Confederación de Trabajadores Venezolanos (CTVConfederation of Venezuelan Workers) as well as in the Federación 
Campesina Venezolana (Venezuelan Peasant Confederation). Labor negotiations, especially tied to the oil industry, were carefully controlled through state-mediated collective bargaining, so as not to stir tensions with foreign oil companies. Acción Democrática's manipulation of workers' unions and the formation of parallel unionism undermined the influence of leftist currents and weakened organized labors' bargaining power (Derham 2010:185). The growth of the oil economy undermined agricultural production, and the continuation of migration from the countryside to the cities, which had intensified under Pérez Jiménez (Derham 2010:176), quickly weakened the peasant class. Land reforms were enacted on a very limited scale, mainly applied to public land, or the land of perezjimenistas (Ewell 1984:139).

In order to contain forces within the party that wanted to push the limits of the pre-signed agreements of the Punto Fijo pact, Betancourt purged the party of radical elements from peasant and labor organizations, and stopped trying to mobilize new groups (Karl 1997:85). Both the Communists and the radical wing of Acción Democrática, whose members had risked their lives in the struggle against Pérez Jiménez, grew increasingly frustrated. In 1960, the youth branch of Acción Democrática left the party in protest. Later, they would re-emerge in the form of a guerilla movement allied with the Communists (Karl 1997:85).

\section{BETANCOURT's LiNE}

The initial phase of Puntofijismo coincided with a shift in the North American approach to Latin America. While Washington had previously supported Pérez Jiménez as a bulwark against communism and because of his openness to foreign capital (Ellner 2008:51), they soon embraced the new democratic dawn in Venezuela. Betancourt appeased the neighbor in the north by signing favorable oil contracts with foreign companies, pursuing a staunch anti-communist line domestically and aiding Washington in politically isolating Cuba (Ellner 2008:62). Indeed, Rómulo Betancourt would become a close friend of both Nelson Rockefeller and John F. Kennedy. Internal struggles with the far left were dealt with through a divide-and-conquer political maneuvering, as well as through raw power, as expressed by the maxim attributed to the interior minister Carlos Andrés Pérez, who would later become president: "Shoot first and ask questions afterwards" (Ellner 2008:60). 


\section{Carlos Andrés Pérez: First Term}

Betancourt was followed by Acción Democrática's Raul Leoni, who largely continued along the political line of the Betancourt years. In 1969, the presidential elections were won by COPEI for the first time, and Rafael Caldera, who founded the party in 1946, took the presidential seat. In 1974, Carlos Andrés Pérez, or CAP as he was also called, was elected president of Acción Democrática at a moment in which Venezuela overflowed with oil revenues - a result of the 1973 OPEC oil bonanza caused by the Arab oil embargo. These were years of lavish spending, and Venezuela was nicknamed "Venezuela Saudita." The country was awash in petro-dollars, social programs were launched in order to mitigate social conflict, and even the labor movement stopped calling for redistributive policies (Ellner 1989:118). According to Karl, the charismatic Carlos Andrés Pérez, or $\mathrm{CAP}$ as he was also called, had an immense ego and desire to leave his mark on Venezuelan history (Hellinger 2000:107). In an address to congress in 1974, he announced far-reaching social and political reforms, as well as a development plan called the Fifth National Plan, designed to put the country on track toward becoming a developed nation. Ambitious industrialization programs were drawn up to change the country's economic structures overnight, and massive infrastructure projects were put in motion (Hellinger 2000:107). Modernity and development were thought to be just around the corner, symbolized by the potent skyscrapers that dominate Caracas's cityscape to this day. As Judith Ewell (1984) put it:

The new wealth and the perceptions of it affected all aspects of national life ... Money abounded to subsidize more publishing and artistic ventures and a reorganization of the state cultural bureaucracy. Middle-class Venezuelans luxuriated in consumption and display of status symbols from imported food and clothing to the acquisition of condominiums in Miami, Florida. Neglected regions received more national investment to create poles of development in the interior. It is doubtful that much of the new wealth reached the poorest and least skilled of the population, but massive development projects encouraged the eternal expectation that soon the wealth would indeed trickle down to the poor. (Ewell 1984:193)

During these years, middle-class Venezuelans went to Miami on weekends for shopping trips, generating the famous expression "está barato, dame dos" [it is cheap, give me two]. Corruption reached unprecedented levels during Pérez's rule (see Karl 1997). The sheer amount of money in 
circulation, a re-organization of the state administration, the massive development projects, and the close linkages between Pérez's office and his close circles of technocrats, business and political allies, gave ample space to corrupt practices. ${ }^{1}$

\section{The Beginning of THe End}

However, the boom didn't last long. Elected in 1979, Luis Herrera Campins, from COPEI, "inherited" a massive foreign debt that had been accumulated during the Pérez years (Ellner 2008:79). In 1983, the combination of reduced oil prices and declining confidence in the economy triggered speculative pressure on the Venezuelan bolivar, leading to the adoption of price controls. ${ }^{2}$ Having borrowed on the basis of anticipated future oil prices, the country now found itself in an economic quagmire as oil prices fell. However, in spite of criticizing Pérez for his borrowing practice, Herrera Campins went ahead and doubled the foreign debt. This placed Venezuela in a state of dependency vis-à-vis foreign creditors that would later lead to a deal with the Bretton Wood institutions. Debt payments absorbed between one-fifth and one-third of the country's annual foreign exchange earnings over the following years. And as Pérez's grandiose development plans were abandoned, highly indebted state companies were left with a bloated bureaucracy and an underutilized work force (Ellner 2008:80).

\section{The Crisis Continues}

The disasters of the previous years had already spurred off voices arguing for privatization and neoliberal reforms. The economic and political deterioration that continued under the presidency of Jaime Lusinchi (Acción Democrática) strengthened these positions. By 1985, foreign-exchange reserves were at a mere USD 1.8 billion, state companies were heavily indebted and corruption was endemic. Many claimed that in the subsequent years, state companies were deliberately bankrupted in order to prepare the ground for privatization (Ellner 2008:81). Lusinchi cashed out on the foreign debt, including parts of it that were allegedly illegal, having been borrowed in contravention of Venezuelan law. The exchange mechanisms applied to foreign debt payment were opaque at best, and even Lusinchi's own planning minister claimed that the currency conversion process implemented in 1983 represented the "greatest state transfer to speculators in world history" (Ellner 2008:82). 


\section{PÉrez's Last Round}

In 1989, Carlos Andrés Pérez was elected president for the second time. Fashioning himself as a nationalist and a defender of el pueblo, he capitalized on popular sentiments resisting privatization, neoliberal policies and economic tutelage under the Bretton Woods institutions. However, in the backroom he had brokered a deal with the International Monetary Fund (IMF), which ensured that significant structural adjustment programs would be implemented once he took office. On February 28, 1989, the government of Carlos Andrés Pérez and the IMF signed a letter of intent that would align Venezuelan petroleum products - which had been heavily subsidized-with prices closer to the international market. On average the prices were to rise 94 percent, and it was scheduled for prices to rise an additional 70 percent in January 1990 (Mommer 1996:147). The IMF deal also included a severe readjustment of interest rates and the deregulation of certain basic commodities in addition to a sharp price increase of others (Ellner 1989:105).

Pérez had called the neoliberal package el Gran Viaje (the great turnabout), portraying it as a necessary measure to safeguard the nation's future. But he underestimated the extent to which the poor part of the population, which throughout the past years had seen living conditions radically worsen, had been brought to their brink. The first phase of Pérez's structural adjustment reform led to the "the largest and most violently repressed revolt against austerity measures in Latin American history" (Coronil 1997:376). The uprising, called el Caracazo or el Sacudón, is described in the next chapter and will not be examined in detail here. Suffice to say that the government's violent response to the massive protest left somewhere between 300 and perhaps as much as 3000 dead. These numbers are still disputed.

Social unrest continued and increased in the aftermath of el Caracazo, leading to violent confrontations between protesters and state forces frequently resulting in injuries and deaths (López et al. 1999). The legitimacy of not only the political parties, but also of the whole political system was free falling. There was also unrest within military ranks. The lower ranks were primarily staffed by young men from poor backgrounds. Dismayed by having been sent out to "kill their own" during el Caracazo, many of them started to question the legitimacy of the Pérez government. One of them was Hugo Chávez, who was already a central figure in clandestine left-wing milieus. He led a secret dissident group within the army, called Revolutionary 
Bolivarian Movement-200 (MBR). In 1992, the group, which had attracted more supporters after el Caracazo (Ellner 2008:96; Trinkunas 2002), led out a failed civil-military uprising against the Pérez government. The justification for the uprising was that the government had lost its constitutional legitimacy after massacring its own people during el Caracazo. The uprising failed and Chávez was jailed, but the cause, and Hugo Chávez himself, gained enormous popular support (see Strønen 2016).

\section{IMPEACHMENT}

At this point there was a sense of chaos in Venezuelan society (see López et al. 1999; Trinkunas 2002). The following year, Carlos Andrés Pérez was impeached on corruption charges, partly becoming a scapegoat for the de-legitimization of the political system at large. Before leaving office, Carlos Andrés Pérez left his mark in the Venezuelan economy. In spite of el Caracazo, the IMF-prescribed shock treatment was implemented. A 1992 privatization law facilitated widespread privatization of strategic sectors. Organized labor was weakened and the informal economy expanded. Except for a few basic commodities, price controls were lifted, tariffs were sharply reduced, and restrictions to foreign investments were removed. This resulted in a massive multinational penetration of sectors such as finance, gasoline retail and fast-food outlets (Ellner 2008:92). Cost of living increased and new sectors of the population descended into poverty. Decentralization laws reduced the powers and responsibilities of the state in a number of strategic areas, while new municipalities were established in affluent areas, diminishing the tax base that befell the poor neighborhoods (Ellner 2008:93).

\section{Paving the Way for Chávez}

Caldera won the presidency in 1994 through embracing an anti-neoliberal discourse and showing sympathies for the cause of Hugo Chávez and his fellow rebels, attributing the coup attempt to the unacceptable social conditions among large parts of the citizenry. In the first phase of his presidency, Caldera took some steps to curb the effects of Pérez's reforms (Ellner 2008:100). However, soon after, the consequences of Pérez's deregulation of the financial sectors started to set in. In the wake of deregulation policies, the banks had gained control over companies in sectors such as telecommunications, agriculture, tourism and broadcasting 
(Ellner 2008:100). However, this expansion soon turned into collapse as a number of banks went bankrupt. Caldera's response to the banking crisis was to take over and administer 18 of the country's 41 banks, representing 70 percent of all deposits (Ellner 2008:100). Moreover, the government permitted foreign takeover in the banking sector, greatly weakening domestic capital. The former bankers fled the country, heading for the United States and elsewhere. With them they brought both the money they had embezzled from the banks as well as the funds the government had injected into the system in order to keep the banks floating. A total of 322 bankers were issued arrest warrants-none were brought to justice (Ellner 2008:100). It was an economic fraud of epic proportions. In the meantime, real wages continued to fall, and inflation reached 71 percent in 1994 and 57 percent in 1995 (Ellner 2008:100).

\section{“The Opening"}

In 1996, Caldera entered into a new deal with the IMF, which he called "Agenda Venezuela." The IMF granted Venezuela a 1.4 billion loan, while also giving its stamp of approval to government policies in order to reassure foreign investors of the country's solidity. In 1997, the national steel company SIDOR was privatized, and the government sold out its last shares in the communication company CANTV. (Both of these companies were later re-nationalized by Chávez.) Health and retirement branches in the social security system were privatized, and severance payment systems reformed in a manner that reduced payouts to workers (Ellner 2008:100-105). Caldera also continued the process of privatization of the oil industry that had begun under Pérez, a maneuver euphemistically termed la apertura (the opening).

As we will explore further in the subsequent chapter, social protests and political unrest was abundant during these years. People in the barrios still spoke of Chávez, and many sympathizers and leftist activists visited him in prison. In 1994, Chávez was granted pardon from Caldera and released from prison. Caldera was an old political hawk, and sensed the popular sentiments that were simmering in favor of Chávez. In 1997, Chávez formed a political party, Movimiento Quinta República or MVR (the Fifth Republic Movement). Chávez toured the country with an anti-establishment message promising to restore justice and dignity to the country, to call for a constituent assembly, and to break with the old Puntofijismo system. In the 1998 elections, Chávez's main electoral 
contender was Irene Sáenz, a former Miss Universe and the mayor of the wealthy municipality of Baruta, in Caracas. Sáenz was faring well on the polls, until she was endorsed by COPEI just before the elections: a move that proved fatal. Chávez won the presidential elections with 56 percent of votes, ending 40 years of Acción Democrática/COPEI hegemony backed by the Punto Fijo pact of 1958.

\section{The Exceptionalism Myth}

It should be noted that the reading of Venezuelan history has in many ways been greatly re-interpreted during the past few decades. Contemporary writers from the Punto Fijo period tended to overlook the underlying internal conflicts and the power struggles simmering below the surface of an apparently functioning democracy. For long, Venezuela was hailed as an exceptional case in Latin America, a designation also referred to as "the Venezuelan exceptionalism." Surrounded by countries marred by military coups and authoritarian dictatorships, Venezuela showcased an uninterrupted line of democratically elected governments since 1958. The Punto Fijo pact sustaining this model has led researchers to term the Venezuelan model "partidocracia" (Rey 1989:266, cited in Hillman 1994:17), "pacted democracy" (Hellinger 1991:94) and "pactocracy" (Cockcroft 1989:340, cited in Hillman 1994:17). Elsewhere, Hellinger defined it as "elections without participation" (Hellinger 1996:4). Few analysts foresaw the breakdown of the Venezuelan political system that started to gain pace since the early 1980s. One exception is Hellinger, who in 1984 wrote: "The Venezuelan state is likely to find itself increasingly caught up in reviving class struggle as the decade proceeds" (Hellinger 1984:56).

Especially in the aftermath of the social and political disintegration starting in the 1980s, as well as after Chávez's electoral victory in 1998, critical research shed light on the cracks in Venezuela's "exceptional" political model. Indeed, Derham has argued that "the myth of a popular, fully representative Venezuelan democracy has been created by an alliance between self-interested democratic politicians and foreign (mainly US) scholars and 'mentors"' (Derham 2010:271). In a similar vein, Ellner indicates that

For many years, political analysts, along with those close to the circles of power in Washington, presented the exceptionalism view by labeling Venezuela as a model democracy due to its stability, marginalization of the left, and avoidance of militant independent trade unionism. (Ellner 2008:2) ${ }^{3}$ 
Moreover, Buxton has argued that the "failure of the state to competently administer elections debased any claim that the country was a 'democracy" (Buxton 2001:103). She argues that not only was the right to vote or have your vote counted often flaunted in practice, but that "the electoral system was rife with gerrymandering and characterized by a lack of regulatory clarity and an absence of institutionalized norms" (see Buxton 2001:82-103 for details).

\section{Oil, Puntofijismo and Foreign Oil}

The abundance of oil revenues is a central factor for explaining the long durée of the Punto Fijo system. As Hawkins notes:

The oil revenues allowed the hegemonic parties to develop an extensive network of clientelist networks, creating mechanisms whereby new political actors were either co-opted or excluded. (Hawkins 2010:89)

A central element of this consolidation of power was to make sure that potentially radical elements were kept at bay (either with carrot or stick), while at the same time ensuring that powerful interest groups and the dominant ascending political base-the middle classes-were satisfied. Acción Democrática, presumably the most radical party as opposed to the conservative COPEI, had radically changed its social and political orientation from the first ruling experience in 1945-1948 to the consolidation of power in 1959 . While el trienio was relatively socially radical, anti-imperialist and nationalist, post-1958 Acción Democrática was staunchly anti-Communist, pro-North America and politically shrewd.

However, intimately interlinked with $\mathrm{AD}$ and COPEI's co-optation over access to oil revenues and positioning in the political game, another process was taking place, shaping Venezuela's economic and political architecture, as well as the country's relation to the global economy. Foreign petroleum companies carved out an extensive space for political and economic maneuvering and revenue extraction, while domestic elites, who were intimately connected to and identified with the global world of extractive business and cosmopolitan ideals, controlled the national oil industry. At the same time, middle-class identities and material interests gradually became, in part through social engineering by the foreign oil companies themselves (Tinker Salas 2009:4), intimately tied to the continuous presence of foreign oil companies. In order to understand how this happened, we need another quick detour back in Venezuelan history. 


\section{Shaping the Petro-State}

The appearance of foreign oil companies under Juan Vicente Gómez's rule took place at a time with surprisingly weak state structure, or in Karl's words: "A legacy of extreme administrative weakness that is remarkable even in the context of Latin America" (Karl 1997:74). Part of the reason was that Venezuela was marginal to the Spanish empire because it had few resources that were attractive to the European emerging markets. The country had been ruled by shifting caudillos, and few administrative structures were developed. The limited scope of the state and the lack of a strong state identity gave the foreign oil companies, backed by the United States, an easy pass once they entered the country. As Karl writes:

Together, they were able to effectively limit Venezuela's sovereignty by fashioning the international oil market and the conditions for domestic business in their favor, redesigning the country's property laws, keeping social forces weak, decisively influencing leaders, and, when necessary, helping to change actual rulers. (Karl 1997:89)

The development of the country in the aftermath of the emergence of the oil industry was conditioned by the encounter between the weak domestic political economy and the most powerful forces of the international economy (Karl 1997:73). The establishment of a petroleum regime subsequently led to what Karl terms "petrolization," or the formation and empowerment of oil-related interest groups to the expense of non-oil-related interest. Oil-related sectors became pegged to the state, discouraging political diversification. The gravitating power of the oil economy also prevented the development of other economic sectors, and undermined the agricultural economy that had been the backbone of the country prior to the oil industry's emergence. Venezuela had become a net importer of food already during Gómez era (Tinker Salas 2009:207), a condition that strongly contributes to its fundamental problems today. Already in 1958, 71 percent of the state's revenues came from oil (Tinker Salas 2009:211).

The oil economy also created a class pattern different from other Latin American countries. Since growth was fueled by oil rents more than by real productive activities, the middle class grew proportionally larger than the working class - an inverted class pyramid propped up on petro-dollars (Karl 1997:82-83). 


\section{The Formation of Petróleos de Venezuela S.A (PDVSA)}

Venezuelan oil production was in its first decades almost entirely dominated by foreign companies. In 1928, there were 107 companies working on Venezuelan soil, but the big three-Dutch Shell, Gulf, and Standard Oil controlled 98 percent of the market (Ewell 1984:63). Most of the exports consisted of heavy crude, and most of it was refined in the Dutch Antilles before it was shipped to the eastern coast of the United States (Ewell 1984:63). Less than 3 percent was consumed domestically (Ewell 1984:63). The "big three" cultivated close relationships with shifting governments, while the US state department carefully monitored the relationship between the foreign companies and the Venezuelan government (Tinker Salas 2009:205).

The first state oil company, Corporación Venezolana de Petróleo, was not created until 1960 (Mommer 1996). On September 10, that same year, delegates from Venezuela, Saudi Arabia, Kuwait, Iran and Iraq gathered in a meeting in Baghdad. Few days later, OPEC was formed (Grisanti n.d.). The Venezuelan delegate, Juan Pablo Pérez Alfonso, played a crucial role in this process.

After having gradually built a national knowledge- and capacity base, and reflecting nationalist currents in and beyond the country, the Venezuelan oil industry was nationalized in 1976 under the first government of Carlos Andrés Pérez. The foreign companies put up resistance, but they had also carefully monitored nationalist sentiments in the country and positioned themselves for a shift in policies. And in effect, international oil companies continued profiting from the Venezuelan oil industry through lucrative service contracts, indemnification, expensive loans, foreign investment diverted to other economic sectors and other mechanisms (Bye 1979:73; see also Hellinger 1984, 2016; Tinker Salas 2009:228-229).

However, the nationalization of PDVSA served another purpose. The popular and working-class agitation platforms of class struggle and nationalist advocacy were neutralized, and replaced by a national consensus ideology (Bye 1979:63). As Tinker Salas notes, political parties and leftist intellectuals for the most part lost interest in oil after the nationalization, while the managers of the oil industry increasingly viewed both politicians and the populace as "a potentially disruptive force" (Tinker Salas 2009:229). Indeed, in spite of the nationalization, PDVSA's Venezuelan 
oil executives continued to share the perspective of the international oil companies that had trained them (Mommer 2004:131). Over time, PDVSA developed into a "state within the state" (Mommer 2004:131), viewing itself as a player on the global scene steeped in corporate neoliberal logic rather than a national state company that had to respond to its owners, that is, the Venezuelan state and the Venezuelan populace. The country's subsequent political leaders failed to put in place efficient fiscal and regulatory systems (Mommer 2004) and the oil giant effectively escaped political oversight.

\section{OIL AND LABOR}

The oil industry was a generous employer to the lucky few who were able to secure work there. In 1958, the 40-50 thousand workers employed by the oil and iron industries, comprising less than 3 percent of the country's total workforce, earned more than half of the country's wages. In addition, their housing, education and health services were provided by their employers (Lieuwen 1961:14). In contrast, the common city wage earner employed in industry and commerce on the other hand, spent 48 percent of his income on food. Less than one-third of dwellings were reported to have running water in the 1957 national census (Lieuwen 1961:13-14). Thus, even if Venezuela reportedly had the continent's highest per capita income at the time-USD 743 in 1962-this wealth was concentrated in the hands of those who benefited (Lieuwen 1961:14) from the oil industry. The labor movement tied to the oil industry emerged as the most powerful part of the Venezuelan labor movement (Tinker Salas 2009:11), prompting some to call them a labor aristocracy (ibid.). As we will discuss more in detail below, the oil industry also became the center of gravity for the ascending managerial and professional classes, allowing them to enjoy an elevated standard of life that resembled that of their middle-class peers in the United States - far beyond reach for the common Venezuelan worker.

The development of the oil industry also intensified the migration from rural to urban areas, as peasants flocked to the oil fields and to the cities in order to find work (Ewell 1984:64). The oil production itself wasn't labor-intensive, but the infrastructures and services (including prostitution) spread and provided job opportunities around the oil areas (Ewell 1984:64). 


\section{Re-ORDERING VeNEZUelan SOCIETy}

The development of the oil industry spurred the construction of large oil camps surrounding the oil fields. As Tinker Salas (2009) has analyzed in detail, the oil camps became an epicenter for the social, spatial and cultural re-ordering of Venezuelan society. Of key importance in these processes were the construction of new divisions between public and private space, the fostering of new ideas of work ethics and personal development, the consumption of new commodities and foods, the promotion of new models for family life, gender relations, citizenship and racial hierarchies, and the promulgation of new forms for social interaction and social rituals (Tinker Salas 2009). Over time, the norms, values and standards of living in the oil camps evolved "into a set of social assumptions and class expectations that defined those employed in the industry and against which other elements of society could measure their own status" (Tinker Salas 2009:171).

The Venezuelans who managed to get a foot inside or in the ambits of the oil industry eagerly absorbed these new political, social and cultural models. Ever since the 1940s, the companies also pursued a strategy termed "venezolanization," seeking to employ Venezuelans in all but the top-level managerial positions. The explicitly stated aim was to ensure that the Venezuelans had a personal stake in the company's presence and that their employees would circulate between oil and the state in a revolving-door manner, safeguarding that the companies' long-term interests would be upheld (Tinker Salas 2009:186). And rightly so, many of them became important actors on other political, commercial and social arenas in Venezuelan society (Tinker Salas 2009:5). Consequently, their views, reflecting "a series of self-sustaining myths about the oil industry and its importance to the nation and society" (Tinker Salas 2009:5) were diffused throughout society.

\section{Oil, Nationalism and Modernity}

At the core of these beliefs was the idea that the foreign oil industry was of paramount importance if the country were to enter into the era of modernity (Tinker Salas 2009:5). The trope of modernity and its association with foreign oil was multi-faceted and forged over time. For one, the foreign oil companies conjured an imagery of themselves as the anti-thesis and solution to the backwardness and thirdworldism of the country prior 
to their establishment in the country. This aligned the companies with the potentiality for progress and modernity, interlocking their presence with middle-class ambitions and the post-1958 developmentalist political leadership. They even embraced and propagated the famous slogan "sowing the oil," first coined by Arturo Uslar Pietri in 1936. Referring to the need to diversify the economy through investing ("sow") oil into other economic arenas, in particular agriculture, the slogan was appropriated by the oil companies who portrayed themselves as key agents in the modernization of the Venezuelan economy (Tinker Salas 2009:190).

The oil companies also carefully monitored communist and nationalist currents in society, working in close relationship with the government and security services (Tinker Salas 2009:213-216). At the same time, they maneuvered diligently to associate themselves with cultural nationalist sentiments in a manner that hedged against the surge of political nationalism that could threaten their interests. The companies engaged extensively in philanthropy as well as making content for media outlets, ranging from radio programs to sponsoring and publishing magazines featuring famous national writers and articles promoting popular and traditional cultural heritage (Tinker Salas 2009:193-199).

\section{The TRIAD}

Seen as a whole, what took place in Venezuela during these decades was the construction of a political and social triad among the dominant political classes, the oil industry and the main beneficiaries from the oil economy: the labor aristocracy, the middle classes and the elites. Their views became hegemonic in the Venezuelan public, and together, like in an echo chamber, they crafted the idea of the oil industry as the exclusive enclave through which modern Venezuela was emerging. As the notion of meritocracy had been cultivated throughout the industry's development (in spite of the central importance of nepotism and networks in hiring practices), people nursed by the oil industry were comfortably reassured of them being deserving of their status and priveleges. This evolved into a sense of privilege as a birthright: they were the pillars upon which modern Venezuela was standing. Concurrently, the middle classes had an intrinsic interest in maintaining status quo, making them essentially conservative and reactionary vis-a-vis political radicalism and the country's underprivileged citizens. 


\section{Oil and Struggle in the Chávez Era}

A picture now slowly emerges of a nation whose social identities and political interests were segregated between those who benefited from the circulation of oil wealth, and those who were cut off from the benefits from not only the oil industry per se, but also the whole array of social, cultural and political arrangements conjured up in its orbit. As Tinker Salas notes: "the portrayal of a prosperous oil economy transforming the nation obscured the fact that a significant portion of the Venezuelan population existed on the margins of the oil economy" (Tinker Salas 2009:6). This picture, when extended into also encompassing an understanding of the extensive corporate and political interests tied to the control over the oil industry, enables us to better understand the enormous shake-up that Chávez' arrival to power, and his gradual attempt take control over the oil industry, represented. Tinker Salas summarizes it succinctly:

At one level, the dispute between Chávez's government, the oil company hierarchy, and the oil workers' unions regarding the future of the oil industry was a struggle for the economic purse string of the nation, a battle between the new PDVSA, aligned with the social priorities of the government, and the old mode. At another level, the dispute was a symbolic contest over the nation's identity, its model of citizenship, and a definition of modernity and progress previously defined by élite and upper-middle-class concerns. (Tinker Salas 2009:207)

The first thing Chávez did in terms of oil policy was to (successfully) reach out to other OPEC countries in order to strengthen cooperation and reach an agreement for limiting production and rising prices (Hellinger 2016:64).

Politically, the Chávez government would not get control over PDVSA until after the oil strike/sabotage in 2003. By then, a struggle had for long been unfolding between the national executive and the PDVSA management. Traditionally, PDVSA executives had controlled the ministry of petroleum by appointing "their people" to ministerial posts, and the ideological position of the PDVSA leadership was essentially neoliberal and pro-privatization. They had for long advocated for the final privatization of the company, putting them in direct confrontation with Chávez's government, who were well aware that they would be politically and economically castrated if they didn't gain control over PDVSA. Tellingly, middle-class employees in the oil industry also formed 
a group called Gente de Petroleo (Oil People) who were actively opposing Chávez.

In November 2001, having been granted special powers by the congress, Chávez passed 49 laws by decree-one of them securing the state full control over the oil sector (Tinker Salas 2015:150). The following months, tensions escalated across Venezuela and rumors of a coup-inthe making were simmering. In early April 2002, Chávez fired several of PDVSA's top executives on live TV. On April 11, 2002, a large opposition march, symbolically convoked to gather outside the PDVSA headquarters in Chacaito, marched toward the presidential palace Miraflores. I will not go into the details of the coup here. ${ }^{4}$ Suffice to say that the coup was well planned and included the use of massive media manipulation, snipers to make it look as if the government had fired on protesters and preorganized dissent among a group of military generals. Chávez, threatened with having the presidential palace bombed, was eventually taken into custody by the military coup plotters. He was later flown to a military base on the island La Orchila off the Venezuelan coast. Eventually, the coup fell apart as a result of internal disagreements among the coup plotters, massive popular mobilization in favor of Chávez, and a series of maneuverings by Chávez's supporters within the military. On April 14, he was brought back to Miraflores.

The coup had been orchestrated by the labor union CTV (historically tied to Acción Democrática), the national business confederation FEDECAMERAS, opposition parties, the private media and dissident military generals. By now, there is also considerable evidence that the United States was involved in the coup at some level (Golinger 2005; Al Jazeera 2009; Villegas 2009; Beeton et al. 2015). When the coup was defeated, Chávez took a reconciliatory tone, setting up the Presidential Commission for National Dialogue. He also re-hired some of the people on PDVSA's top executive board, who had been fired on live TV. However, in December 2002, the PDVSA management, as well as CTV, FEDECAMERAS and the opposition parties called for an indefinite general strike. The purpose was to force Chávez out of power by creating a situation of in ungovernability and popular discontent.

PDVSA was subsequently shut down by upper-management against the will of the petroleum worker union FEDEPETROL and other smaller unions (Ellner 2008:119). Other opposition-led businesses also orchestrated lockouts, while the majority of businesses in non-affluent areas remained open (Ellner 2008:119). As gasoline reserves dried up, 
the country came to a halt. Citizens were forced to queue for up to two days to fill a tank of gasoline, and people died as ambulances ran out of gasoline and could not attend to emergency calls. Supermarkets ran out of basic goods as the supply system broke down. In the barrio households, which cannot afford to store large quantities of food, people scraped together whatever they could find to eat, sharing among family, friends and neighbors. Many had to burn their furniture for cooking and sterilizing baby bottles. ${ }^{5}$ The strike lasted eight weeks, although it was never formally called off. The government managed to take over the oil establishments that had been closed, with the help of the military, retired personnel and loyal workers, and production slowly regained pace (see Tinker Salas 2015:163-168 for a detailed account of these events). The sabotage affected the popular sector the most, but the popular uprising that the sabotage-plotters had hoped for never materialized. Rather, people rather stoically endured the hardships in a spirit of collective struggle, turning their anger toward the conservative sectors that was strangling the country for political purposes.

\section{The People’s Oil}

The effects of the strike were devastating; GNP declined 24 percent that year (Weisbrot and Sandoval 2007) and poverty rates spiked drastically. Nevertheless, the government came out as the winner after the strike. It removed 16,000 (mostly white-collar) PDVSA workers who had participated in the strike, and took political control over the company. As Tinker Salas notes, "many Venezuelans applauded Chávez's efforts to rein in the oil conglomerate” (Tinker Salas 2009:233).

Following this takeover, PDVSA was ideologically re-fashioned as a guarantor of social development and national sovereignty. Not only was a large portion of oil revenues channeled into the government's so-called social missions that were rolled out during the following years (see Chap. 4 ), but the company also had an active role in many of them. Contracts with foreign companies were reviewed and re-negotiated giving PDVSA a majority stake in all joint ventures, and taxes and royalties were raised. In 2005, Petro-Caribe was established, through which several economically vulnerable Latin American nations were provided with Venezuelan oil through long-term credit arrangements (Tinker Salas 2015:151; see Hellinger 2016 for a review of Chávez's oil policy). Through an oil-fordoctors exchange with Cuba, the government's flagship social program, 


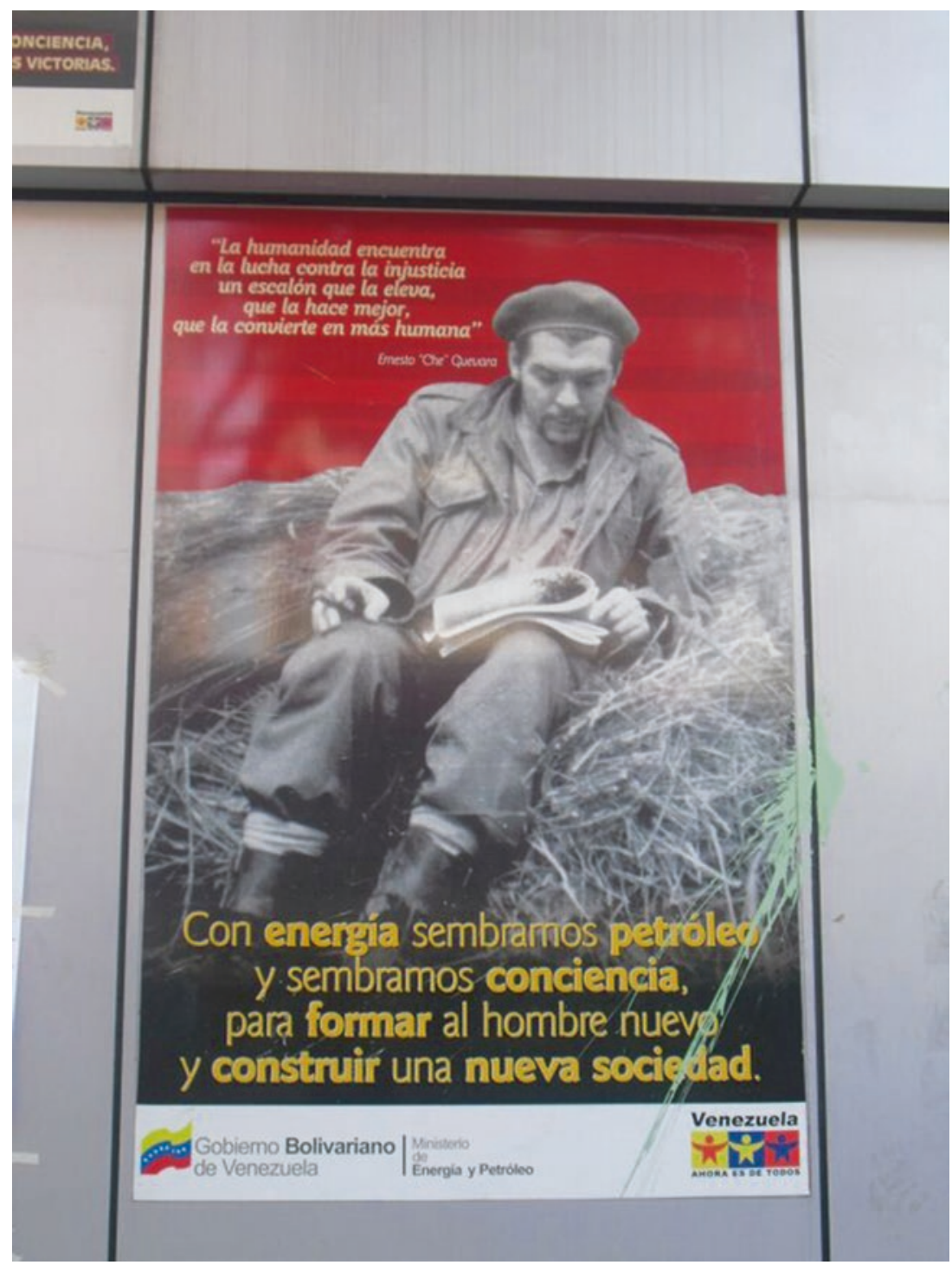

Photo 2.1 Poster of Che Guevara made by the Ministry for Energy and Petroleum. It reads: "with energy we sow oil and we sow consciousness in order to form the new man and construct a new society." Photo by the author 
Barrio Adentro (Into the barrio), was established, setting up health clinics across Venezuela staffed with Cuban doctors.

Ideologically, these moves were fashioned as a break with corporate, neoliberal logic, and PDVSA became a potent symbol for national sovereignty, social justice, international solidarity and integration between developing countries. To Chávez's supporters, the symbolic remaking of PDVSA as well as the government's policies of steering oil revenues into social welfare became a very tangible evidence of the government's commitment to comply with radical demands from below.

This chapter has chronicled a broad-and far from exhaustive-trajectory of Venezuela's political and social history in the twentieth century. The narrative shows that oil is an indispensable key for understanding the most significant features of Venezuela: its economic strengths, weaknesses and inherent vulnerability, the solidity and durability of the Punto Fijo system, the Punto Fijo system's eventual demise, the country's development efforts and failures, the formation of different classes with diverging social ideologies and world views, and eventually, the rise of Hugo Chávez and the dense significance of oil in his rule.

As a social anthropologist, I am interested in the ways in which a passive agent (oil) becomes formative for molding social and political dynamics and structures (see Mitchell 2011). As previously stated, this is the argument that I am trying to puzzle together in this book; we need to understand oil as property that works through political structures, economic processes, and social relations in a multiplicity of ways. The rest of this book is an attempt to trace the "secondary effects of oil," that is, how the political and structural legacy of oil, its cultural representations and social expectations gained salience in the Bolivarian process as lived in the barrios of Caracas. To start that journey, we will now turn our attention to the relationship between Chávez and his supporters.

\section{Notes}

1. Ellner (2008:72) identifies Pérez with a leftist, pro-Third World current in opposition to the more moderate and conservative currents within Acción Democrática. That being said, Pérez was originally associated with the Betancuristas, having been Betancourt's personal secretary in the 1940s and minister of the interior in the 1960s when he was accused of orchestrating 
massive human rights abuses (Ellner 2008:71). However, during his presidency, Pérez re-established relationships with Cuba, supported the Sandinistas in Nicaragua and advocated for a strong interventionist role of the state as a means to achieve greater independence vis-à-vis the developed countries (Ellner 2008:72). In 1976, the oil industry was formally nationalized, though, as we will discuss more in depth below, the nationalization did not lead to a real process of independence from foreign oil companies operating in Venezuela. However, in spite of conflicts with the more conservative Betancourtista currents in the party, Pérez never engaged in a real confrontation with established interests, and he didn't mobilize broad popular support. His outreach to the labor movement was rather lukewarm (Ellner 2008:73).

2. The new exchange regime established a three-tier system, which according to Ellner could have worked hadn't it been for the excessive irregularities and corruption associated with it (Ellner 2008:79).

3. It can be argued that there were some aspects about Venezuelan politics that were exceptional. Venezuela had less visible manifestation of class conflict than other countries, the working class was less violently and systematically repressed than in countries like Bolivia and Argentina, and the vast oil resources channeled through clientelist mechanisms discouraged collective struggle (Ellner 2008:2). Moreover, the internal mechanisms developed within the dominant multi-class parties allowed for the negotiation of class disputes, and social mobility, especially within the military, contributed at times to easing social tensions (Ellner 2008:2-3).

4. Detailed accounts of the coup can be found in Bartley and Ó Briain (movie) 2003, Golinger 2005, Palacios (movie) 2004, Villegas 2009, Gott 2005. For an analysis angled from the oppositions' point of view, see Nelson 2009.

5. Most people in the barrios cook on gas stoves.

\section{BIBLIOGRAPHY}

Al Jazeera. 2009. US 'Likely Behind' Chavez Coup. Al Jazeera, September 21. http:// www.aljazeera.com/news/americas/2009/09/200992116049879437.html. Accessed February 20, 2017.

Beeton, Dan, Jake Johnston, and Alexander Main. 2015. Venezuela. In The Wikileaks Files: The World According to the US Empire, ed. Wikileaks. London and New York: Verso.

Buxton, Julia. 2001. The Failure of Political Reform in Venezuela. Aldershot, Burlington, USA, Singapore and Sydney: Ashgate.

Bye, Vegard. 1979. Nationalization of Oil in Venezuela: Re-Defined Dependence and Legitimization of Imperialism. Journal of Peace Research 16 (1): 57-78. 
Coronil, Fernando. 1997. The Magical State: Nature, Money, and Modernity in Venezuela. Chicago: University of Chicago Press.

Derham, Michael. 2010. Politics in Venezuela. Explaining Hugo Chávez. Oxford, Bern, Berlin, Bruxelles, Frankfurt am Main, New York, Wien: Peter Lang.

Ellner, Steve. 1989. Organized Labor's Political Influence and Party Ties in Venezuela: Accion Democratica and Its Labor Leadership. Journal of Interamerican Studies and World Affairs 31 (4): 91-129.

- 2008. Rethinking Venezuelan Politics. Class, Conflict, and the Chávez Phenomenon. Boulder and London: Lynne Rienner Publishers.

Ewell, Judith. 1984. Venezuela. A Century of Change. London: C. Hurst \& Company.

Golinger, Eva. 2005. El Código Chávez. Descifrando la intervención de los EE.UU en Venezuela. Caracas: Fondo Editorial Question.

Gott, Richard. 2005. Hugo Chávez and the Bolivarian Revolution. London and New York: Verso.

Grisanti, Luis Xavier. n.d. ¿Sembrar el petroleo o sembrar ciudadanos? Petroleo $\Upsilon V$. http://www.petroleoyv.com/website/uploads/grisanti_5.pdf. Accessed February $20,2017$.

Hawkins, Kirk. 2010. Venezuela's Chavismo and Populism in Comparative Perspective. Cambridge: Cambridge University Press.

Hellinger, Daniel. 1984. Populism and Nationalism in Venezuela: New Perspectives on Acción Democrática. Latin American Perspectives 11 (4): 33-59.

- 1991. Venezuela: Tarnished Democracy. Boulder, San Francisco and Oxford: Westview Press.

- 1996. Introduction. Latin American Perspectives 23 (3): 3-9.

- 2000. Review: Understanding Venezuela’s Crisis: Dutch Disease, Money Doctors, and Magicians. Latin American Perspectives 27 (1): 105-119.

- 2016. Oil and the Chávez Legacy. Latin American Perspectives 44 (1): 54-77.

Hillman, Richard. 1994. Democracy for the Privileged. Crisis and Transition in Venezuela. Boulder and London: Lynne Rienner Publishers.

Lieuwen, Edwin. 1961. Venezuela. Oxford: Oxford University Press.

Lopez, Margarita M., David Smilde, and Keta Stephany. [1999] 2002. Protesta y culturaen Venezuela. Los Marcos de Acción Colectiva en 1999. Caracas: FACESUCV, CENDES, FONACIT.

Karl, Terry Lynn. 1997. The Paradox of Plenty. Oil Booms and Petro-States. Berkeley: University of California Press.

Mitchell, Timothy. 2011. Carbon Democracy: Political Power in the Age of Oil. London: Verso.

Mommer, Bernhard. 1996. Integrating the Oil: A Structural Analysis of Petroleum in the Venezuelan Economy. Latin American Perspectives 23 (3): 132-158. 
2004. Subversive Oil. In Venezuelan Politics in the Chávez Era: Class, Polarization, and Conflict, ed. S. Ellner and D. Hellinger. Boulder and London: Lynne Rienner Publishers.

Nelson, Brian. 2009. The Silence and the Scorpion: The Coup against Chavez and the Making of Modern Venezuela. New York: Nation Books.

Strønen, Iselin Åsedotter. 2016. "A Civil-Military Alliance": The Venezuelan Armed Forces before and during the Chavez-Era. CMI Working Paper Series 2016:4, Chr. Michelsen Institute, Bergen.

Tinker, Miguel S. 2009. The Enduring Legacy. Oil, Culture, and Society in Venezuela. Durham and London: Duke University Press.

- 2015. Venezuela. What Everyone Needs to Know. New York: Oxford University Press.

Trinkunas, Harold. 2002. The Crisis in Venezuelan Civil-Military Relations: From Punto Fijo to the Fifth Republic. Latin American Research Review 37 (1): $41-76$.

Villegas, Ernesto P. 2009. Abril, Golpe Adentro. Caracas: FUNDARTE.

Weisbrot, Mark, and Luis Sandoval. 2007. The Venezuelan Economy in the Chávez Years. Washington, DC: Center for Economic and Policy Research.

\section{Audiovisuals}

2003. The Revolution Will Not Be Televised. Dir. Kim Bartley and Donnacha O'Briain. Galway, Ireland: Power Pictures.

2004. Puente Llaguno: Claves de una Masacre [Llaguno Bridge: Keys to a Massacre]. Dir. Ángel Palacios. Caracas: Producciones Panafilms.

Open Access This chapter is distributed under the terms of the Creative Commons Attribution 4.0 International License (http://creativecommons.org/ licenses/by/4.0/), which permits use, duplication, adaptation, distribution and reproduction in any medium or format, as long as you give appropriate credit to the original author(s) and the source, provide a link to the Creative Commons license and indicate if changes were made.

The images or other third party material in this chapter are included in the chapter's Creative Commons license, unless indicated otherwise in a credit line to the material. If material is not included in the chapter's Creative Commons license and your intended use is not permitted by statutory regulation or exceeds the permitted use, you will need to obtain permission directly from the copyright holder.

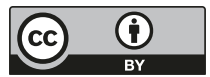




\section{Understanding the Bolivarian Revolution from Below}

"We were sitting at home watching Chávez on TV when he gave the famous por ahora speech," Rosa, a staunch Chávez's supporter from Catia, recalled. "Afterwards, I said: 'there is our future president." " As we learned in the previous chapter, Chávez had led an unsuccessful military uprising against the government of Carlos Andrés Pérez (Acción Democrática) in February 1992. After the arrest, he was allowed to speak on national TV. Wearing his red signature beret, he was cast into the spotlight of Venezuelan public life, becoming a popular hero for large parts of the population. The words por ahora (for now) signaled that the fight against the then loathed political status quo was not over, and that Chávez could be the man leading that fight. Moreover, having for long been accustomed to politicians that lied and deceived, ${ }^{1}$ the population finally saw a man who was willing to take responsibility for his actions. A poem, handed to him in jail by an anonymous supporter, illustrates the sentiments that he incited in people at the time:

Our Chávez who is in jail

holy be thy coup

come (to revenge) to us, your people

make your will come through

that of Venezuela

that of your army

give us today the confidence already lost

and don't forgive the traitors

as we will neither forgive

(C) The Author(s) 2017 
those who apprehended you.

Save us from all the corruption, and liberate us from Carlos Andrés Pérez.

Amen.

(Elizalde and Baez 2004:9, author's translation from Spanish)

Six years later after his imprisonment, Chávez would move into the presidential palace Miraflores, sustained by a wave of popular support.

\section{SHIFTING THE LENS}

Many scholarly analysis and media accounts focus on the "gravitational power" that Chávez's figure exercised, some of them with an explicit undertone that portrays his supporters as passive and ignorant recipients of a seductive political message (e.g., see Corrales 2001; Canache 2002). However, in this and the following chapter, I will explore Chávez's appeal by turning my attention away from his public persona for a while. That does not imply that I want to remove Chávez from my analysis; rather I posit that we have to slightly shift our perspective. If we focus too much on Chávez as a charismatic figure and ideologue, we miss the opportunity to appreciate the "thick background," to paraphrase Geertz (1973), which preceded and prepared the ground for people's support of the successive Chávez governments. In my analysis I will therefore focus on the shared historical experiences of marginalization and collective struggle that people from the popular sectors perceived as the background for embracing Chávez's political project. We will then be better equipped, I believe, to turn our attention back to Chávez's persona and understand how he was able to incite such popular support.

However, before we proceed, it is necessary to dwell a bit on the recurring classification of Chávez as a populist. Populism as a concept has been closely associated with Latin American politics though it has, in recent years, also been used to explain new political movements in Europe, the former Soviet Union and even contemporary US politics. Populism as a political style is generally understood to have surged in Latin America from the 1930s to the 1950s, supporting import-substitution industrialization (Weyland 1999:379) and gaining support from the working class. Examples of politicians embracing this approach are Juan Perón in Argentina, Lázaro Cárdenas in Mexico and Jorge Eliécer Gaitán (who was murdered) in Colombia. In more recent times, political leaders combining 
popular mass appeal with neoliberal policies have frequently been described as neopopulists (Ellner 2003). Examples are Alberto Fujimori in Peru, Fernando Collor in Brazil and Carlos Menem in Argentina.

However, the term "populism" itself remains highly contentious among researchers. As Jansen (2011) states, even academic discussions about the concept rely on folk theories (Jansen 2011:76). Indeed, "every usage of the term is overly general, applying to any person, movement, or regime that makes claims by appealing to ordinary (i.e., non-elite) people" (Jansen 2011:76). Several scholars have questioned the usefulness of the concept, though there have been a number of attempts to define and operationalize it for comparative analysis (Knight 1998; Weyland 2001; Roberts 2006; Jansen 2011).

\section{The Faceless Masses}

The purpose here is not to assess whether Chávez was a populist or not. In the descriptive and reductionist sense, or what we can summarize as "the political mobilization of mass constituencies by personalistic leaders who challenge established elites" (Roberts 2006:127), he certainly was, and it is beyond the scope of this book to engage in a discussion about populism as a concept. ${ }^{2}$ However, I do want to dwell a bit on what the labeling of Hugo Chávez as a populist entails in qualitative terms. There frequently is an inherent normativity in the use of the term "populist" which tends to lean toward describing a pathological trait of political culture, "to imply that the accused is corrupt, undemocratic, or cynically opportunistic" (Jansen 2011:77). This implicitly converts populism, as a concept, into a powerful weapon for discrediting political movements that appeal to the disadvantaged classes rather than to middle- and upper-class sectors. ${ }^{3}$ Populism becomes a catch-all phrase for a political form of advocacy for the rights and identity politics of certain sectors of the population. Obscuring the class politics in it, such an approach conveniently isolate and limit a political movement to a form or a relationship, without taking into account the historical context, or broader relations of power and domination circumscribing the political and social domain at large.

This use of the term is exacerbated by the fact that the concept belongs more to the realm of comparative politics and political sciences than to that of anthropology and ethnographically oriented sociology. This disciplinary dominance tends to produce an analysis that portrays "the masses" as a "faceless mass," responding in an instrumental way to the strategic 
maneuvers of a charismatic leader. Thus, the political agency of the electorate responding to this "populist call" and the relational and interpretative space between leaders and their supporters tend to be left as an explanatory open void.

It is precisely this void that I want to explore in this chapter, by focusing on people's own agency for engaging with the Bolivarian process, and their own historical experiences that sustain the world view and political alternatives that Chávez sketched out. Arditi (2007) has argued that populism is liberal democracy's "awkward guest": one which we seek to ignore, but which is nevertheless intrinsic to liberal democracies' entrenched shortcomings (Arditi 2007:78). "[Populism] is a symptom of democratic politics; it grants visibility to the founding negativity of the political by summoning the disruptive 'noise' of the people" (2007:78). In this view, populism is therefore a mirror to liberal democracy; it makes visible the claims and voices of those who are disenfranchised or muted within liberal democracy's architecture of power and privilege. This also explains why populism is so uncomfortable for the mainstream polity; it reminds us of how liberal democracy's idea of equal rights co-exists with the de facto unequal consummation of those rights.

If we adhere to the view that Chávez was a populist in the conventional, descriptive usage of the term, we may also read the evolvement of the Bolivarian popular process as a historical, context-specific reaction to how the particular architecture of liberal democracy in Venezuela marginalized large parts of the populace, both materially and identity-wise. This view frames the Bolivarian process as a political populist alternative where the "disruptive noise" of the people was finally forcefully heard and given a political space. It is impossible to properly understand the Bolivarian process without understanding its supporters' previous experiences with Venezuela's elite-controlled liberal democracy, and how they juxtaposed this epoch with Chávez's political message and project. The disruptive noise of the people had been present for a long time in Venezuelan society, only to be met with violence and censorship.

\section{A History of Popular Organization}

"Are you a Chavista as well?" I asked the feisty retired school teacher from 23 de Enero. She looked at me over the glasses in a typical teacher manner. "I have always been a revolutionary, and now I am a Chavista. And we will defend him to wherever, sick or not." This was said when 
Chávez had undergone his third cancer surgery in Havana in December 2012. "We will stand by him through whatever, unless he turns against el pueblo. Then..." she said, indicating that people's loyalty was dependent on Chávez's loyalty to the people who brought him to power. "But he would never do that," she said, convinced.

Social struggle in Venezuela didn't begin with the figure of Chávez. The popular sectors in Venezuela come from a long process of political and social resistance that multiplied, expanded and took on a new form when Chávez emerged on the national political scene. The variety of movements and networks supporting the Bolivarian project were highly heterogeneous in form as well as in focus. They were composed of a variety of activists, old and new, and a wide range of organizations, networks and groups with different genesis and organizational characteristics.

Contemporary urban movements trace their genealogy through four decades starting in the 1950s (Fernandes 2010:40). The 1950s were characterized by clandestine resistance to the authoritarian regimes, culminating with the overthrow of Marcos Pérez Jiménez in 1958. The following decade was dominated by guerrilla struggles brought about by the political exclusion of the left following the Pact of Punto Fijo. The 1970s were characterized by a surge of cultural activism, merging political activism with a wealth of cultural expressions among the popular sectors. The escalating socio-economic crisis of the 1980s generated a new wave of popularized resistance and public protest which, as we will see below, became increasingly violently repressed.

\section{0s: The Guerrilla Strategy}

Radicals from the Partido Comunista de Venezuela (PCV) as well as from Acción Democrática played a crucial role in bringing the dictator Marcos Pérez Jiménez down in 1958. From the 1940s onward, both parties built their support base on the popular sectors (Fernandes 2010:44). However, both PCV and the new radical party Movimiento de Izquierda Revolucionaria $(\mathrm{MIR})^{4}$ became excluded from formal political participation under the government of Rómulo Betancourt (1959-1964). Inspired by the Cuban revolution and deprived of other democratic channels, this political exclusion gave birth to a guerrilla movement that organized itself in small rural guerrilla units known as focos (Ciccariello-Maher 2013:32). The rural guerrilla units were also linked to networks in the popular urban neighborhoods, where they found food, shelter and storage for their 
weapons. This also made the popular neighborhoods and members of the excluded political parties a target of state repression.

The guerrilla movement was violently repressed by the state. Clashes happened all over the country, and most of the first guerrilla members were killed at an early stage (Ciccariello-Maher 2013:32). The political protest of students, peasants and workers was also met with state violence during the early Betancourt years. Ciccariello-Maher quotes a senior citizen who moved to Caracas in 1956: "The Betancourt years were the worst! It was lead, lead and more lead! His policy was to shoot first and ask questions later" (Ciccariello-Maher 2013:27).

The guerrilla conflicts waned down toward the end of the 1960s due to the progressive liquidation of combatants by state forces, tactical errors and internal rivalries (Ciccariello-Maher 2013). The decline of the guerrilla movement was also partly related to the so-called pacification strategy put in motion by Rafael Caldera (COPEI) when he gained the presidency in 1969 (Fernandes 2010:49).

Moreover, the guerrilla members increasingly found themselves without popular mass support (Ciccariello-Maher 2013). In the following decade, radical political parties growing out of the guerrilla struggle such as PRV (Party of the Venezuelan Revolution) and MAS (Movement for Socialism) would become important arenas for developing a "Venezuelan political radicalism," uniting "reformed guerrilla members" and new nascent political radicals. Urban struggle developed on various fronts (Ciccariello-Maher 2013:47), creating a radical current of leftist intellectuals, workers, students, cultural activist and other popular sector leftist networks and organizations. What remained of the guerrilla groups operated on both an open electoral and a clandestine front (Ciccariello-Maher 2013:65). Facing a "zealously repressive state apparatus" (CiccarielloMaher 2013:64), the legal fronts focused on organizing students and workers in mass protests, while also publishing radical newspapers. However, these "backroom" guerrilla groups lost legitimacy and failed to garner mass support, in particular after the high-profile kidnapping of an American businessman, referred to as the Niehous case (Ciccariello-Maher 2013:59-64). This kidnapping case also led to the arrest of some 400 revolutionary leaders. Many of the militants were also killed, further eroding the support base of what was left of the post-guerrilla organizations (Ciccariello-Maher 2013:61).

State-sponsored political mobilization was channeled through the clientelist apparatus of Acción Democrática at the time, which tapped into 
the popular sectors through a vast network of local neighborhood committees, including comités de barrio (barrio committees) and comités de base (base committees) (Fernandes 2010:46). Edgardo Lander describes this system as having a "populist-paternalist-clientelist character" (Fernandes 2010:46), creating a strong dependency on the state and weakening horizontal bonds in the community (Fernandes 2010:46). Constituting a threat to this mode of social control, the police would raid the popular neighborhood, looking for those considered insurgent and subversive.

Even though the guerrilla strategy never obtained mass support, these early forms of popular urban resistance played a central role in fomenting counter-hegemonic currents of resistance. Many of the activists I spoke to recall that their parents or relatives were politically active at the time. Thus, in spite of the evident guerrilla failure in terms of accomplishing revolutionary goals, this political epoch had a formative effect in shaping social and political consciousness in the barrios, providing a narrative of struggle that strongly informed political agency and ideology from below in the Chávez era.

\section{0s: The Cultural Turn}

While some continued to organize political parties and fronts, others turned to cultural politics during the 1970s (Fernandes 2010:49). This shift partly reflected a de-politization of the left, while cultural politics were incorporated into wider social and political struggle against the marginalization of popular sector neighborhoods (Fernandes 2010:49). Simultaneously, worker priests, formed by liberation theology, played an important role in mobilizing local communities against deficiencies in the health, education and infrastructure systems. The most important figure was the Belgian priest, Francisco Wuytack, based in the community of La Vega in western Caracas. He was deported by President Rafael Caldera in the 1970s, accused of interfering with internal politics and fomenting illegal street demonstrations (Fernandes 2010:51). However, Wuytack left an important legacy of mobilization and political consciousness that to this day makes La Vega one of the most politically vocal neighborhoods in Caracas (see Strønen 2006; Fernandes 2010).

In 23 de Enero, a new form of community activism also took shape, focusing on sports, cultural and social work. That is however not to say that that these activities were void of political content, or that the former political networks of the 1960s had disappeared. Rather, the new 
community organizations represented a new strategy for popularizing political ideas. This intertwining of culture and politics was highlighted by Ernesto, my host while I lived in 23 de Enero. He is now in his 60 s but has lived in 23 de Enero and participated in popular struggles since his youth:

[During other events] or the Holy Week we carried out activities that were related to religion, but also connected to another element, that of protest, the struggle. And of course all these things, as we now perfectly know, were monitored by the Venezuelan state and by its security organs. In the case of cultural and sports activities, these were a possibility we can say, a valve, that one could use for capturing people, in this case youths ... and be able to communicate a message as well, try to bring forward what one thought was best.

Moreover, protests and confrontation with state forces continued, and the focal point for struggle was the deficiency in basic infrastructures and services in the community. The 1970s were also marked by the ascendance of several significant popular folk singers who combined their artistic expressions with political activism, such as Grupo Madera and Ali Primera. Several of the members of Grupo Madera died in a boat accident in 1980, in what many believed was a "deliberate act of negligence on the part of the government" (Fernandes 2010:56). Ali Primera died in 1985, in what many people still today think was a rigged car accident.

\section{0s: The Battle Is in the Streets}

The 1980s saw the intensification of a direct and open conflict between the popular sectors and the state. The social control exercised by Accion Democrática through its paternalistic-clientelistic maneuvers waned as a result of multiple causes: a general economic decline and rise in poverty and unemployment rates, as well as the de-legitimization of the political parties and entities attached to it, such as the worker's union and neighborhood committees. Acción Democrática's growing inability to contain social activism through the continuation of clientelism and patronage meant that a new and broader field of social protest was opened up. Several and interrelated fronts of activism emerged.

Of central importance are the neighborhood or community movements, which have a long history in Venezuela (Rivero Santos 1995). Roughly speaking, neighborhood movements can be divided into two 
different organizational categories (López et al. 2002:63). As we just learned, popular sector demands were channeled through the clientelistic apparatus of Acción Democrática in exchange for electoral support. In the upscale neighborhoods on the other hand, community organizations exercised pressure on municipal authorities in order to tackle existing challenges in their urbanizations ${ }^{5}$ (Lopez et al. 2002:63). However, as the political ties between the popular sectors and the traditional political parties became weaker, neighborhood associations in the popular sectors increasingly started to stage street protests targeted at local authorities. This shift was also related to de-centralization reforms carried out in the 1980s, which transferred decision-making power and resources to local governments, while also reinforcing the segregation of neighborhoods with a strong or weak tax base (Fernandes 2010:58-59). The combination of impetus from the cultural politics of the previous decade and focus on local challenges consolidated a new form of activist identity and political thinking rooted in local communities (Fernandes 2010:59-60).

Street protests, where students played a central role, became a frequent form of protest from the 1980s onward, starting with the government of Jaime Lusinchi (1984-1989) (Lopez et al. 2002:13). The student movement has a long and vibrant history dating back to the nineteenth century (Lopez et al. 2002:148). Student protests frequently took the form of socalled encapuchados- masked protestors carrying out violent actions such as burning tires, barricading streets and throwing stones and Molotov cocktails. The students not only protested against the increasing deterioration of the quality of education, educational facilities, and student support, but they also became of central importance in organizing protests against the deterioration of living conditions in the popular sectors. During the 1980s, the student movement became the main target of state repression and many students were killed (Amnesty International 1980).

The 1980s also gave birth to the so-called colectivos, mainly located in 23 de Enero (see Chap. 5). These radical, often armed, groups emerged not only as a response to the increasing incursion of drug trafficking and crime in popular sector communities, but also as a response to the violent practices of state forces. Indeed, many people viewed drug trafficking and police abuse as two sides of the same coin, as the police was allegedly central in masterminding drug trafficking in popular sector neighborhoods, seeking to undermine social cohesion and popular organization.

"Street politics" is the term that López et al. (2002) use to describe the increasing practice of street demonstrations taking place in Caracas during 
the 1980s and 1990s. These represented a "peculiar form of relation and negotiation between diverse social sectors and power" (López et al. 2002:9). Protests not only became more commonplace, but their nature was also more confrontational and aggressive. Moreover, new members of the society that hitherto had not participated in social protests, such as retirees, also went to the streets. These new modalities of social protest evidenced a shift in the relations between society and the agents of power (Lopez et al. 2002:10). The apparent social pact between Acción Democrática and sectors of the working class was shattered. In the absence of any other arena for articulating political demands, people increasingly took to the streets to voice their demands. The state responded with violent repression of a social sector that was increasingly vilified among the dominant sectors of society.

Finally, it is important to remark that the emergence of these forms of street protest and tentative organization around rights-based demands in Venezuela from the late 1980s coincided with similar trends across Latin America, coupled with a global tendency to frame citizenship around the notion of "rights." The increasing deprivation of conditions for social reproduction constituted a key mobilizational platform for these demands, as did the struggles for broadening "sociopolitical citizenship" (Escobar and Alvarez 1992:4), making identity struggles and claims for alternative spaces for political deliberation key foci for activism. Thus, in tracing the genealogy of popular mobilization in Venezuela, we can find a pattern of similar trends across the continent. In broad term, the foci of struggle shifted from the targeted criminalization and persecution of the left under the banner of the war against communism during the Cold War, to the increasingly broadening struggle between the state and a variety of social forces demanding basic rights and recognition (see Escobar and Alvarez 1992; Alvarez et al. 1998).

\section{The Hostile State: Memories from the Fourth REPUBLIC}

In his song "Alberto Lovera hermano," the popular folk singer Ali Primera commemorates Alberto Lovera, a teacher, leftist activist and secretary general of the Venezuelan Communist Party (PCV) who was kidnapped, tortured and killed by Venezuelan security forces in Caracas on October 17, 1965. 
You came out of the water in chains

Accusing, those who killed you

Your clamour is always heard

Revolutionary clamor

Your clamour is always heard

Alberto Lovera brother

They wanted, they wanted to hide your body

They tried, they tried to drown your clamour

Your clamour is always heard

Accusing, accusing

Your clamour is always heard

Alberto Lovera brother

And it is the clamour of your people

The clamour of your beloved fatherland

Alberto Lovera brother

Your death will be revenged

Alberto Lovera brother

Your death will be revenged

$(\ldots)^{6}$

Lovera's body, wrapped in metal chains, got caught in a fisherman's net in the coastal state of Anzoátegui ten days later. Lovera's face, fingers and teeth had been crushed to complicate the identification process.

Albero Lovera was far from being the only prominent political activist who died by the hands of the police and security forces during the Punto Fijo period. Other high-profile victims include Fabricio Ojeda, the leader of the Patriotic Junta that overthrew the dictator Marcos Pérez Jiménez, and Jorge Rodriguez, the founder and secretary general of the political movement and party, Liga Socialista. Other particularly notorious episodes from the Puntofijo period include the Massacre of El Amparo in the state of Apure in 1988, where 14 fishermen were shot from behind and later presented as Colombian rebels killed in combat by Venezuelan security forces. Six years earlier, 23 members of a guerrilla cell from the radical underground movement of Bandera Roja (a political party as of 1994) had been ambushed and assassinated in what is called the Massacre of Cantaura, in the state of Anzoátegui. In May 1986, in what is called the Massacre of Yumare in the state of Yaracuy, nine political activists were captured and killed, and many of them tortured. The initial official version in all cases was that these individuals were guerrilla members killed in combat by security forces. 
Venezuela received relatively little international attention for its human rights situation at the time. As reports of the gross human rights violations taking place elsewhere at the continent slowly became known, the world's attention was focused on the brutal dictatorships in Chile, Argentina, Brazil and Uruguay in the southern cone, and Nicaragua, Guatemala and El Salvador further north. Approximately 30,000 people were killed during Argentina's “dirty war." In Chile, approximately 3000 were killed and 40,000 tortured under General Augusto Pinochet's dictatorship. In Guatemala, it is estimated that 200,000 people were killed, the majority from the indigenous population.

And indeed, the persecutions taking place in Venezuela were not as systematic, or on the same scale of the aforementioned countries. Besides, Venezuela was a formally elected democracy. Nevertheless, political persecution and human rights violations took place in an extensive manner, targeting mainly leftist leaders and activists, those associated with the communist party, the guerrilla, the student movement and community activism. Amnesty International's report from 1980 opens with the following statement:

During the year Amnesty International has been mainly concerned about allegations of arbitrary imprisonment and short-term detention, "disappearances", killings and torture by security forces. (Amnesty International 1980:170)

The state's persecution of political dissenters implied that leftist political activists had to operate clandestinely. Yet, they ran the risk of being identified and targeted. This is how Alfredo, an activist in 23 de Enero, recalls an event of his childhood, some 40 years back:

ALFREDO: I remember once when we were kids ... we had a communist flag hidden beyond the refrigerator ... this was after they banned the communist party, we had to hide such things ... outside our house, we were living over at Monte Piedad then, a group of adecos and copeyanos were gathered together with some police ... my little brother found the communist flag behind the refrigerator and ran out and past them waving the flag, split naked!! My mother yelled that I had to go after him, I ran after him and got him back home in the house ... but the police came to 
our house and beat up my father .... But then they let him go to the toilet ... he climbed out of the a small window and ran away as fast as he could and hid over there in the barrio ... the day after we were at school, down there in la Cañanda, and someone told us that the police was on its way ... you know they had been looking in the registers in the Ministry for Education, ta, ta, ta our names, the sons of [name removed], my father ... when we heard that we took off and ran as fast as we could up to el Mirador, we ran the whole hill...

ISELIN: Did they really come for you, you were just kids?

ALFREDO: They were looking for my father! It was a dictatorship; they came after communist and the radicals. They didn't want any leftist movement to surge.

The persecution of Alfredo's father was nothing unusual at the time (except that one must admire his little brother's boldness). We were sitting in his living room in his worn-down apartment in 23 de Enero when he told me this story. As he talked, he was scrambling through all his books and magazines trying to find a poster of the most well-know "martyrs" of that time-leftist radicals that had been killed by the police and army. Many of them came from 23 de Enero. It was Alfredo that showed me the Spanish version of the Amnesty International report that is referred to above: its cover brown and its pages yellow, worn by time. "I don't know how I managed not to get killed," he said. We had talked the whole afternoon about how the police and army treated people in the barrios, and leftist activist in particular, during the Fourth Republic. Kill first and ask afterwards. Torture. House raids. Violent repressions of manifestations. Illegal detention. As a member of MAS and inhabitant of the political hotbed 23 de Enero, Alfredo knew many of those who had felt the mano duro (hard hand) of the state. A cousin of his was beaten and hung by the arms in a shower at the police station for 24 hours. Alfredo himself was only gravely beaten once, with a metal stick when the police rounded up some people by the bloques in Monte Piedad. "The guys hit me three times over my behind," he said, pointing to his bottom.

But as I always carried my wallet and a notebook in my back pockets, it didn't hurt. Then they commanded us to run. I didn't want to run a coño, so they guy started to hit me on my back. People were watching and booing 
and throwing bottles from the bloques. The guy hit and hit until another officer yelled that he had to stop, that he would kill me. He stopped and I walked away and ran home. Some neighbors came running and yelled to my mum "Señora Alvarez, Señora Alvarez, they are killing your son over by the bloques." "No, no, he is here," my mum responded. I must have been 16,17 years old.

Many times, the victims were not even involved in politics; they were only in the wrong place at the wrong time. One young kid in the neighborhood was shot and killed because he ran down the stairs with a stapler in his hands, and a police officer who saw him thought that it was a gun and shot him dead. Another time, the police yelled to a man passing by that he should stop. But he was deaf-mute and didn't hear them so he continued walking. They killed him on the spot. I asked what the families could do in such cases. Alfredo shrugged as if saying "nothing."

One boy over there in the bloques had a goodbye party with his family and friends before he was going to enroll in the military cuartel—you know that they hung up lists sending the boys to there and there. They ran out of caña (liquor) and he ran down to the shop to buy some more. There he met some police officers who tried to rob him of the caña. They started to fight and the police dragged him down here to the local police station.

Alfredo pointed to the building down by the metro station that used to be a feared police station, but which now operated as the headquarter for the colectivo Coordinadora Simón Bolívar.

There he was beaten up. His relatives started to alert people and many came running to the police station gathering outside yelling that the boy should be set free. This often happened when someone was arrested. The police called for back-up forces. Somehow the boy managed to escape and they ran after him. The caught up with him in the stairs leading up to his house. $\mathrm{He}$ was shot in the back. They put a hood on him and carried him down to the jefatura. The next day, the newspaper reported that a hooded man had been shot dead while participating in an attack on the police station.

It was common that the police or security forces planted arms or drugs or dressed victims up as guerrillas or encapuchados (with hoods) in order to justify their killings. This way, it was difficult for the families to push their case, and the officers got to add a notch to their belt. "Like the false 
positives now recently in Colombia," Alfredo said. He was referring to the revelations about members of Colombian security forces who murdered campesinos and dressed them up as guerrilla members in order to cash the reward that the army had promised for "dead terrorists." "People hated the police here," Alfredo said. "It was above the Policía Metropolitana who did these things, they were like a mafia."

\section{EVERYDAY REPRESSION}

Everyday repression of the popular sectors was also commonplace. Here is a story as recounted by Juan Alberto, now a political activist and Chávez's supporter in his early 30s from Catia Parish:

This must have been in the early nineties because I remember that I was wearing the school uniform from the liceo (secondary school). I was on my way home when the bus was stopped by the police on the way up the hill. The police entered the bus and ordered all males to line up and show their ID card. I had forgotten my ID card at home, and the police said that I was arrested. I protested and said that they must see that I was wearing a school uniform, that I was just a school boy, but they just pushed me in the back of the van with the others, I think they rounded up 10 or 12 men there. First we were sent to the police station down in Catia, where they left us in the backyard. I remember that I had to take a piss so desperately that I couldn't think of anything else, I asked the police officer if I could take a piss, but he told me to shut up, otherwise I would be sent to a cell.

After a while came a van from the National Police, they were driving from station to station picking up detainees, and we were taken to the main police station in 23 de Enero. There we were put in a cell. We were ordered to line up and take off all belts and shoelaces and stuff like that, so we wouldn't hang ourselves. Then they gave all of us three beatings on the back with a flat baton. I had to take a piss so desperately that I didn't even feel the beatings. Then a police officer came in, he was drunk, and said that someone had said that we had a gift for him, and if he liked the gift, he would let us go. People scrambled to collect the money that they had, I had nothing of course, and handed it over to him. But he just tossed it to the floor, screaming that it was not enough. We were all poor so it wasn't much. I remember how the other men threw themselves over the money on the floor, fighting over how much each of them had put in.

We stayed in the cell that night; we must have been around 20 men in one cell. I had to sleep on the floor next to the toilet, I remember that I put 
on the hood in my sweater and tied it as tight as I could around my head, there were cockroaches everywhere running over me.

The next morning everyone in the cell put together some money and one of the good cops went out to buy us some bread and mortadela (cheap sandwich ham). The other men gave me some food as well, even though I had no money. Later that day they allowed us to take a phone call. I called my aunt Christina because she was the only one in the family that had a phone then. But she wasn't at home, I think I spoke with my little cousin Julio and told him to find my mum and tell him where I was. So I just waited and waited, thinking coño de su madre (shit), since there was no phone at home they would have to find a car and go up the hill to find my mum. It would take forever. Finally, late in the evening, I heard that my mum and my brother came. The police officer said that they would have to give him a bottle of whiskey if they wanted to have me freed. My brother got furious saying that he wasn't going to give him shit, I heard my mother yelling that I was underage and that it was illegal to have me there. Then another police officer came and intervened, he said that the other police officer who wanted whiskey was drunk and had been up drinking since last night. So eventually they let me go and we went home.

Arbitrary arrest of men was a quite common occurrence. Often the purpose was merely, as in the story above, to get bribes from detainees in exchange for their release. Sometimes, police officers rounded up all the young men that they could find. Those who couldn't prove that they were studying or working were sent off to the army, backed by a law against vagrancy. At other times, the police entered the barrios with the purpose of finding and eliminating personal foes or criminal elements. As Juan Alberto recalls it, police incursions in the poor neighborhood constituted a constant potential threat of violence:

When I was a kid it wasn't the fear of the malandros (street gangs/criminals) that stopped us from hanging out in the street, it was the risk that the police would come. Sometimes they came and just rounded up all the men who were there, or sometimes they came to look for someone specific and then it was shooting and shooting and no one was safe. I remember once they were looking for my neighbor Johnny who was living in front of me, we were friends when we were younger, but then he became a malandro .... I was standing on the roof of our house watching it ... the police came banging on his door, yelling "where is he, where is he," his girlfriend was standing on the floor in the patio (backyard) screaming and screaming ... the police stormed in and searched all the rooms, they found him in his bed, and they shot him dead right there in his bed. 
Both of these stories, as recalled by Juan Alberto, took place in the early 1990s. Stories like that of Juan Alberto and Alfredo are often recounted by popular sector inhabitants and activists as a manner of illustrating how everyday state violence during the Fourth Republic was carried out, creating a sense of being under permanent siege by a hostile state apparatus.

Simultaneously, the escalating political protests were increasingly met with violence during the 1990s. According to López and Parker, "one out of three nonviolent protests was repressed, with an elevated cost in human lives" during the government of Carlos Andrés Pérez (López et al. 2005:97). Repression of protests diminished during the subsequent Caldera presidency (1994-1999), when approximately one out of six protests was violently repressed. However, the state's antagonism toward the poor had already left a deep and collective open wound due to an event that took place a few years earlier, namely the Caracazo in 1989.

\section{El Caracazo}

People came down from the cerros (shantytown hills) and started to loot the shopping mall Propatria. ${ }^{7}$ The police came in masses and started to shoot. They gathered on the roof of the mall and shot indiscriminately up towards the cerro (shantytown hill). Many people were looting a department store some stories up in the mall. The police gathered in front of the door and shot people as they came running out. They shot them down like rabbits. I saw a lot of people lying around here dead. Afterwards they took the bodies and dumped them over at el Cementerio del Sur in the mass grave. That is why we still don't know how many people died.

Juan Alberto, 33 years old from Propatria. A young school boy at the time, he escaped his mom's house during el Caracazo in order to loot notebooks.

No event in Venezuela, perhaps with the exception of the 2002 coup against Chávez, is etched in people's minds as deeply as the Caracazo uprising. ${ }^{8}$ The riot started on February 27, 1989, and lasted several days. Probably the first IMF riot in the world, tens of thousands of people reacted spontaneously to the consequences of a new round of structural adjustment reforms (see Chap. 2). However, the reforms were just the last straw, as social misery and unrest had been growing for years. The distance between the governing elites and the impoverished masses had 
become so wide that the authorities never saw it coming. In the narratives of el Caracazo there is a strong sense of betrayal-not only because Carlos Andrés Pérez lied during his electoral campaign and imposed new IMF reforms once in office, but also because the use of indiscriminate violence against the poor population was so massive. El Caracazo made it clear that the illusion of a social contract between the poor and the rest of society was irrevocably compromised. From that moment on, the popular sectors become increasingly radicalized, which explains the massive support for the attempted coup led by Chávez in 1992. This, in turn, paved the way for the election of Chávez in 1998.

The slogan "el pueblo tiene hambre" [the people are hungry] was frequently scribbled on walls during el Caracazo (Coronil and Skurski 2006:110). Preceding the riots, the poor part of the population had seen their living conditions worsened over a period of several years. This was not only related to a general condition of unemployment and a deterioration of working conditions, education, health and other public services, but also to a situation of widespread hunger and malnutrition, where people were struggling to feed themselves and their children. Rosa illustrated the desperate situation that many people were facing like this:

Look, there was a time when people ate dog food here, a dog food called Perraina. They gave dog food to their children because it was cheap. And when the producers of the dog food realized that people bought it as food, they increased the prices! Imagine that! If you tell this to people, many will say that it was a lie. But I remember. Not everyone, but many people ate dog food.

In 1989, only 30 percent of Venezuelan households were economically capable of meeting their basic needs, that is, to purchase the stipulated basic food basket and additional necessities (Pedrazzini and Sanchez 1992:16). Research carried out at the time concluded that the calorie consumption in the barrios in Caracas dropped from $2327 \mathrm{kcal}$ per day in 1983 , to $1869 \mathrm{kcal}$ per day in 1989-far below an adult's estimated daily minimum intake. ${ }^{9}$ The consumption of proteins dropped in particular (Cavendes 1990:41, cited in Pedrazzini and Sanchez 1992:17). This is also consistent with what people have told me about their diet at the time. They basically survived on rice, some beans and arepa (cornflour bread). Meat was an uncommon luxury. This is how Juan Alberto recalls his childhood diet: 
ISELIN: JUAN ALBERTO:
So what did you eat?

Well, in the morning we normally just had a coffee. And for school we sometimes had a cold arepa or nothing. I remember how it felt like sitting on the school desk being so hungry that I couldn't think. I remember once that one of my class mates who had more money than us looked at my arepa and asked if I wanted to switch, he had one of those Yoko juices and a sweet bun filled with vanilla cream. I just threw him the arepa and grabbed his lunch pack and ran before he could change his mind.

When we got home from school, it was rice and beans for lunch. My grandma made food for all of us, all the siblings and my cousins who she was also taking care of at day time. She covered the floor with newspapers and put all of us there, we were sometimes as much as 12 kids, and then she gave all of us a plate of rice and some beans. I think she must have cooked like a kilo of rice each day. I didn't really eat meat until I was a teenager. If we sometimes had a piece of meat, it was the cheap ham, the mortadela. ${ }^{10}$ Or we killed one of our hens that we kept in the backyard and shared it among all of us. Or sometimes a can of sardines or tuna fish. But we usually ate rice and arepa, rice and arepa, and beans. I used to move the few black beans around at the plate as I ate, so that it would seem like there was more of them. In the evening it was arepa with margarine. I used to fill the arepa with rice if there was some left from the lunch, so it was more filling. Or sometimes there was nothing to eat in the evening.

ISELIN: And what did you do then?

JUAN ALBERTO: Then I went to bed hungry.

The Pérez government enacted some social policies in the form of direct monetary subsidies or assistance programs targeted toward the poorest in an attempt to mitigate the social crisis that was unfolding. However, 
according to my informants, these programs were poorly developed at best. One girl recalled that the relief provided through one of the government's food relief programs took the form of her school teacher sitting at his desk with a piece of ham, distributing small pieces of the meat among the students.

Moreover, the government's social policies only partially compensated for the abrupt deterioration of living conditions, as the traditional programs (health, education, and housing) also deteriorated (Lander and Fierro 1996:65). The government's social expenditure per capita in the 1989-1991 period was the lowest since 1968 (Lander and Fierro 1996:66). Diseases, thought to have been eliminated, reappeared, infant malnutrition increased, as did mortality and infant mortality (Lander and Fierro 1996:66). These worsening living conditions, coupled with an increasing rage against the political system and widespread state violence, help us understand the repressed rage that was unleashed with el Caracazo. The uprising was a perfect storm that had been brewing for a long time, and a rejection of the system that for a long time had increasingly proved itself to be corrupt, violent and hostile toward the poor majority which was paying the price for political decisions taken away from its spheres of participation. Rosa, after having described the years and months leading up to the Caracazo, said:

it was something ... something horrible, horrible, horrible all this that was taking place ... it is almost indescribable, I cannot say to you "look, this happened, this is what it felt like," it was like a torment of many things, of many emotions, of many things that had been repressed and people took to the streets to protest.

According to the late Fernando Coronil, el Caracazo was "the largest and most violently repressed revolt against austerity measures in Latin American history" (1997:376). The popular sector neighborhoods were swarmed with police and armed forces that shot and killed indiscriminately, riddled residential complexes with holes of machine gun fire, rolled into the communities with military tanks, and dragged activists out of their homes for execution (Ciccariello-Maher 2013:96). A report by the Relatives of Victims Committee (Comité de Familiares de Victimas) estimates that 97 percent of the victims were killed in their own homes (Ciccariello-Maher 2013:97). The number of people that were killed is 
still disputed - at the time, official estimates placed it at 300, while popular estimates put the number as high as 3000 casualties. The newspaper quickly stopped reporting on the number of causalities (Coronil and Skurski 2006:118) and the Pérez government sought to obstruct investigations in the aftermath of the massacre (Ciccariello-Maher 2013:96). People searched frantically for their loved ones in overfilled jails, hospitals and morgues. Decomposing bodies were piling up in the morgues, and the city ran out of coffins (Coronil and Skurski 2006:118). Soon thereafter, morgue workers told desperate family members that unidentified bodies had been driven away by trucks—in garbage bags. In 1990, a mass grave was opened in El Cementerio de Sur in Caracas, and 68 bodies wrapped in plastic bags were unearthed (Ciccariello-Maher 2013:97). This secluded spot in the cemetery is still vivid in people's mind and is known as El Nuevo Peste (the new plague).

While the riots in the rest of the country were quelled after three days, Caracas was in an upheaval for five days (Ciccariello-Maher 2013:97). Famed for its radical stance, 23 de Enero was particularly targeted by state forces. The bloques are, up to this day, riddled with bullet holes. The lack of concern in distinguishing between looters and non-looters, as well as women, children and the elderly, illustrates to what extent "the poor" had become a single adversary-one group identified as an enemy of the state. Ernesto, a long-time revolutionary who has lived in 23 de Enero all his life, recalls it like this:

ISELIN:

I remember that you told me once about the military tanks coming up to the square outside your house [in 23 de Enero].

ERNESTO: $\quad$ Yes, exactly, at the square.

ISELIN: When was this?

ERNESTO: This was like the 27, 28 [of February 1989], or I think March 1, because it was difficult for them at first to get into 23 de Enero. And of course, they were busy elsewhere, with other disturbances ... but as they quelled those disturbances, 23 de Enero was what was left ... so they paraded towards 23 de Enero in their tanks, the National Guard in particular, and of course some units from the army ... they came to bloque 26 , bloque 24 and 25 , to 
the central zone of 23 de Enero, like bloque 1 ... to the area of Monte Piedad, bloque 5 , bloque 7 , bloque 6 , they were ... floor 12 and upwards were virtually bullet-holed indiscriminately, including the roof and everything ... people were terrified, the children, the elderly .... and of course afterwards no one apologized or anything...

I'd say that the psychological damage that they did to those people, well ... no one can imagine what could have happened ... some people died from a heart attack ... of course, imagine a situation like that?

And of course, afterwards reports were made, human rights and all that, but at the time these things didn't work very well here, and it wasn't even possible to put forward a serious denouncement, because if you were detected, you were converted into a target for any of these [state] bodies and any of these functionaries could carry out reprisals against you or anyone in your family or your friends ... so it was necessary to be very careful.

Even after el Caracazo, the government didn't make any concessions to the demands of the poor sectors (Lopez et al. 2002:17). Public popular protests continued and increased. According to the Venezuelan NGO Provea, a total of 7092 public protests took place between 1989 and 1999, constituting an average of two protests per day (Lopez et al. 2002:9). The number of protests peaked between 1992 and 1994, which correspond to the years of Chávez's failed coup (1992) and of Carlos Andrés Pérez's conviction for corruption (1993) (Lopez et al. 2002:9, Table 1).

\section{Oil in the Fourth Republic}

What took place during the 1980s and 1990s was not only the breakdown of a political and economic model; it was also the breakdown of an idea about a nation. As Derham (2010) terms it, the Venezuelan state increasingly revealed itself to be an "antagonistic state" for large sectors of the population. A central part of this antagonism consisted of state violence 
combined with a sense of being forced to shoulder the price for the elite's mismanagement and usurpation of national wealth.

During my field interviews, I often asked middle-aged or elderly people what they thought about oil during the Puntofijo era. To my surprise at first, almost everyone responded that they didn't think about it, or that they didn't know much about it. However, it soon dawned on me that this professed lack of consciousness about oil to a large extent was a reflection of the schism between "the two Venezuelas": that of the middle and upper classes imagining themselves in the core of and benefiting from the oil state, and that of the popular sectors who had no means to partake in the symbolic and material manifestations of its riches. As one elderly woman said: "oil didn't concern us, oil was for the oil people."

If we remember Coronil's words about the little that we know about how subaltern lives were lived in the shadows of the Magical State, it is my belief, through numerous conversations, that people were above all concerned with mitigating life's innumerable challenges in their immediate life worlds. However, that does not mean that the grandiose imagery of the Magical State that he describes was not present though the everpresent promises and political spectacles that the poor were also exposed to. Indeed, as Ewell indicates (Ewell 1984:193) and as we will address more in depth later on, Carlos Andrés Pérez's golden period in the 1970s in particular conjured an imagery of prosperity being just around the corner, also for the poor. However, in spite of these expectations and the Venezuelan state's dazzling spectacles, people's tangible experiences with the state were above all characterized by marginalization and oppression. While some experienced a growing frustration leading to an enormous anger with the whole system (as evidenced by the frequent protests during the 1980s and 1990s), others again described themselves as apathic during these years. They had no interest in or concern for politics. It belonged to the realm of "the others."

However, historical memory is a malleable imaginative horizon. As Schwartz notes, "the way ordinary people conceive the past, reflects the concerns of the present" (Schwartz 1997:470, cited in Auyero 2001:183). And I believe that we can safely assume that knowledge about oil was present at some level for most people, even if they felt that it didn't concern them. However, if we do contend that our focus in the present shapes our memories of the past, it follows that Chávez's promise to redistribute oil gave new meaning to their memories of the Fourth Republic. It was through Chávez's political message that many people internalized that 
they actually, as citizens of the oil-rich nation-state Venezuela, were coproprietors in the nation's wealth. Through this new sense of collective entitlement, collective memory-making of the "absence of oil" gained a strong imaginative and emotional power. Following Tilly's notion of collective memories having structuring capabilities (Tilly 1994a:244, cited in Auyero 2001:184), Chávez's call for popular involvement in the state's effort to pay its historical debt to the poor through redistributing the nation's oil wealth provided them with a deep sense of historical revindication.

This sense of continuity between their collective deprivation in the past and their collective struggle in the present was a strong impetus for exploring and shaping new venues for grassroots activism. We will return to this theme in Chap. 5.

In this chapter, I have addressed how popular sector support for the Chávez government built on historical trajectories of popular mobilization dating decades back, and how people recall their experiences of being marginalized and oppressed during the Puntofijo-era. In the following chapter, I will explore the structural and spatial dimension of Venezuela's class division, and how Chávez's rise to power, and the political empowerment of previously marginalized groups, produced a deep confrontation in Venezuelan society. I want to start by inviting the reader on a journey where the oil money that never reached the barrios did flow; to the wealthy districts of Eastern Caracas.

\section{Notes}

1. Unwillingness on the part of Venezuelan politicians to assume responsibility for their actions has translated into the colloquial expression "yonofui" [yo-no-fui, it wasn't me].

2. Elsewhere, the differences between the neopopulism of Hugo Chávez and Alberto Fujimore, often referred to as prime examples of the resurgence of Latin American populism, have been analyzed in depth (Ellner 2003; Roberts 2006).

3. Here I must be quick to note that I am mainly thinking of left-wing populism in Latin America, as right-wing populism as we are seeing in contemporary Europe and the US should be treated separately and as a contextually different phenomenon. 
4. MIR was founded in April 1960 (Fernandes 2010:48) by members of Acción Democrática who left the party in protest against its lack of radicalism.

5. Urbanizaciones is the Venezuelan term for middle- and upper-class neighborhoods dominated by gated condominiums.

6. Ali Primera's music was declared national patrimony by the Venezuelan government in 2005. This is the author's translation from Spanish of the original lyrics which can be found on http://www.musica.com/letras. asp?letra $=1389248$.

7. A huge shopping mall in Catia called Centro Comercial Propatria, which is still operating.

8. El Caracazo is also sometimes called El Sacudón (from saqueo which translates into looting).

9. The daily estimated consumption need in Norway is about $2150 \mathrm{kcal} /$ day for an adult inactive woman and about $2600 \mathrm{kcal} /$ day for an adult inactive man (Smith Sørhøy and Heir n.d.). It is reasonable to assume that the great majority of adults in the popular sectors in Caracas at the time were carrying out hard physical labor or otherwise had a significant level of physical activity, such as manual household labor, carrying water or walking long distances in the absence of adequate and affordable public transport.

10. Mortadela is a cheap ham sandwich, similar to a bologna sandwich.

\section{BiBLIOGRAPHY}

Alvarez, Sonia E., Evelyn Dagnino, and Arturo Escobar. 1998. Cultures of Politics, Politics of Cultures: Re-Visioning Latin American Social Movements. Boulder: Westview Press.

Amnesty International. 1980. Amnesty International Annual Report 1980. London: Amnesty International Publications. https://www.amnesty.org/en/ documents/poll0/0003/1980/en/. Accessed February 20, 2017.

Arditi, Benjamin. 2007. Politics on the Edges of Liberalism. Difference, Populism, Revolution, Agitation. Edinburgh: Edinburgh University Press.

Auyero, Javier. 2001. Poor People's Politics. Peronist Survival Networks and the Legacy of Evita. Durham and London: Duke University Press.

Canache, Damarys. 2002. From Bullets to Ballots: The Emergence of Popular Support for Hugo Chavez. Latin American Politics and Society 44 (1): 69-90.

Ciccariello-Maher, George. 2013. We Created Chávez: A People's History of the Venezuelan Revolution. Durham and London: Duke University Press.

Coronil, Fernando. 1997. The Magical State: Nature, Money, and Modernity in Venezuela. Chicago: University of Chicago Press. 
Coronil, Fernando, and Julie Skurski. 2006. States of Violence. Ann Arbor: University of Michigan Press.

Corrales, Javier. 2001. Strong Societies, Weak Parties: Regime Change in Cuba and Venezuela in the 1950s and Today. Latin American Politics and Society 43 (2): $81-113$.

Derham, Michael. 2010. Politics in Venezuela. Explaining Hugo Chávez. Oxford, Bern, Berlin, Bruxelles, Frankfurt am Main, New York, Wien: Peter Lang.

Elizalde, Rosa Miriam, and Luis Báez. 2004. Chávez Nuestro. Havana: Casa Editora Abril.

Ellner, Steve. 2003. The Contrasting Variants of the Populism of Hugo Chávez and Alberto Fujimori. Journal of Latin American Studies 35 (1): 139-162.

Escobar, Arturo, and Sonia Álvarez. 1992. The Making of Social Movements in Latin America. Identity, Strategy and Democracy. Boulder, San Francisco and Oxford: Westview Press.

Ewell, Judith. 1984. Venezuela. A Century of Change. London: C. Hurst \& Company.

Fernandes, Sujatha. 2010. Who Can Stop the Drums? Urban Social Movements in Chávez' Venezuela. Durham and London: Duke University Press.

Geertz, Clifford. 1973. The Interpretation of Cultures. New York: Basic Books, Inc.

Jansen, Robert. 2011. Populist Mobilization: A New Theoretical Approach to Populism. Sociological Theory 29 (75): 75-96.

Knight, Alan. 1998. Populism and Neo-populism in Latin America, Especially Mexico. Journal of Latin American Studies 30 (2):223-248.

Lander, Edgardo, and Luis A. Fierro. 1996. The Impact of Neoliberal Adjustment in Venezuela, 1989-1993. Latin American Perspectives 23 (3): 50-73.

López, Margarita M., David Smilde, and Keta Stephany. 2002 [1999]. Protesta y culturaen Venezuela. Los Marcos de Acción Colectiva en 1999. Caracas: FACESUCV, CENDES, FONACIT.

López, Margarita M., Luis Lander, and Dick Parker. 2005. Popular Protest in Venezuela: Novelties and Continuities. Latin American Perspectives 32 (2): 92-108.

Pedrazzini, Yves, and Sanchez R. Magaly. 1992. Malandros, Bandas y Niños de la Calle. Cultura de Urgencia en la Metropoli Latinoamericana. Valencia and Caracas: Vadell Hermanos Editorial.

Rivero Santos, Angelo. 1995. Neighborhood Organizations in Venezuela: "Los Vecinos" Voice Their Dissent. Yearbook: Conference of Latin American Geographers 21: 1-12.

Roberts, Kenneth. 2006. Populism, Political Conflict, and Grass-Roots Organization in Latin America. Comparative Politics 38 (2): 127-148.

Sørhøy, Marit Smith, and Wenche Heir. n.d. Energi og energibehov. Digitale læremidler for videregående opplæring. NDLA. http://ndla.no/nb/ node/61375. Accessed February 20, 2017. 
Strønen, Iselin Åsedotter. 2006. "For Us This Is Utopia Coming True.” Venezuela's Bolivarian Revolution and Popular Movements in a Caracas Barrio. MA thesis, Department for Social Anthropology, University of Bergen.

Weyland, Kurt. 1999. Neoliberal Populism in Latin America and Eastern Europe. Comparative Politics 31 (4): 379-401. 2001. Clarifying a Contested Concept: Populism in the Study of Latin American Politics. Comparative Politics 34 (1): 1-22.

Open Access This chapter is distributed under the terms of the Creative Commons Attribution 4.0 International License (http://creativecommons.org/ licenses $/$ by $/ 4.0 /$ ), which permits use, duplication, adaptation, distribution and reproduction in any medium or format, as long as you give appropriate credit to the original author(s) and the source, provide a link to the Creative Commons license and indicate if changes were made.

The images or other third party material in this chapter are included in the chapter's Creative Commons license, unless indicated otherwise in a credit line to the material. If material is not included in the chapter's Creative Commons license and your intended use is not permitted by statutory regulation or exceeds the permitted use, you will need to obtain permission directly from the copyright holder.

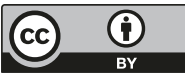




\section{The Politics of Space, Race and Class}

April 2011: Finally I had a Saturday off and I decided to go to the wealthy eastern part of Caracas together with a friend. I had planned on doing this for a long time, but I never found the time. During all my stays in Venezuela I probably spent 95 percent of my time in the western part, the poor part, in Municipio Libertador. My axis of movement, my comfort zone, went from the middle of Sabana Grande crossing over to Plaza Venezuela and moving on toward Parque Central, to Plaza Bolívar and continuing to the presidential palace of Miraflores on the outskirts of the city center, and from there on to the barrios stretching out to the west. The west is a place of both great pains and great pleasures, of overcrowded streets and overcrowded houses, of yelling street vendors and deathdefying motorizados (motorcycle drivers), of aggressive traffic jams and honking camionetas (small buses), of shouting and music and car horns during the day and the occasional gun shot at night, of cheap restaurants and street stalls surrounded by the odor of frying oil, of the sweet smell of garbage rotting in the street, of murales (stencils and artistic graffiti) and political slogans on the walls, of pro-government politics and people dressed in red T-shirts, of the pains of poverty and the resilience that accompanies it. This was what I knew. On this motorcycle trip I was finally about to see another side of Caracas.

The city of Caracas is squeezed into a narrow valley and can be crossed from one end to the other quite quickly (at least hypothetically, if one ignores the congested traffic). We rapidly crossed the city on 
our motorbike via the highway going through Municipio Chacao and Municipio Baruta. As we raced between the cars, the city became notably more spacious, cleaner and more orderly. In the east, we reached the entrance to El Hatillo. This municipality of about 70,000 inhabitants is conformed both by high-class residential areas and by low-class neighborhoods in the valleys to the north. A large Welcome to El Hatillo sign greeted us in both English and Spanish. The road climbing up to the sector called Los Naranjos was steep and windy with upscale residential apartment buildings hovering over the sides of the hills. The motorbike was working hard to get us up the hill. On the way up I only saw one graffiti on a wall. It read: "Hugo, me cago en tus leyes" [Hugo, I shit on your laws].

As we finally made it to the top, we stopped for a drink at a roadside kiosk. Outside the kiosk was a giant stack of opposition newspapers, El Nacional and El Universal, while two copies of the pro-government newspaper Diario Vea were half-hidden on the news stand. There was almost no one to be seen, just a few nice-looking cars driving by. The apartment buildings were surrounded by gates and protected by a uniformed guard at the entrance. On the other side of the valley we could see some giant mansions, scattered around the lush landscape. The abundance of green bushes and vegetation around us gave the area an airy, fresh feeling - a stark contrast to the east, where almost no green space can be seen.

We got back on the motorbike and continued upward, until we reached the Centro Commercial Los Naranjos, a mid-size exclusivelooking shopping mall hovering over the valley. As we continued up the road, we reached the entrance to a gated community on the right-hand side. Behind the gates we got a glimpse of a white mansion built as a copy of the White House in Washington. I wanted to go closer to get a picture, but we were well aware that two people on a motorbike taking photos would probably raise fear here, and I was worried that if we got any closer the guard at the entrance would call the police before our roadtrip had even begun. So we continued upward and east, toward La Lagunita, one of the really posh neighborhoods. Along the road continued the nice-looking, well-maintained apartment buildings and the gated mansions. Still, curiously, almost no people could be seen. We finally reached La Lagunita Country Club, one of the private leisure clubs for the really rich, complete with a golf course that could be barely seen behind the gates. Reaching the end of the golf course we passed through a small roundabout and continued into another really upscale 


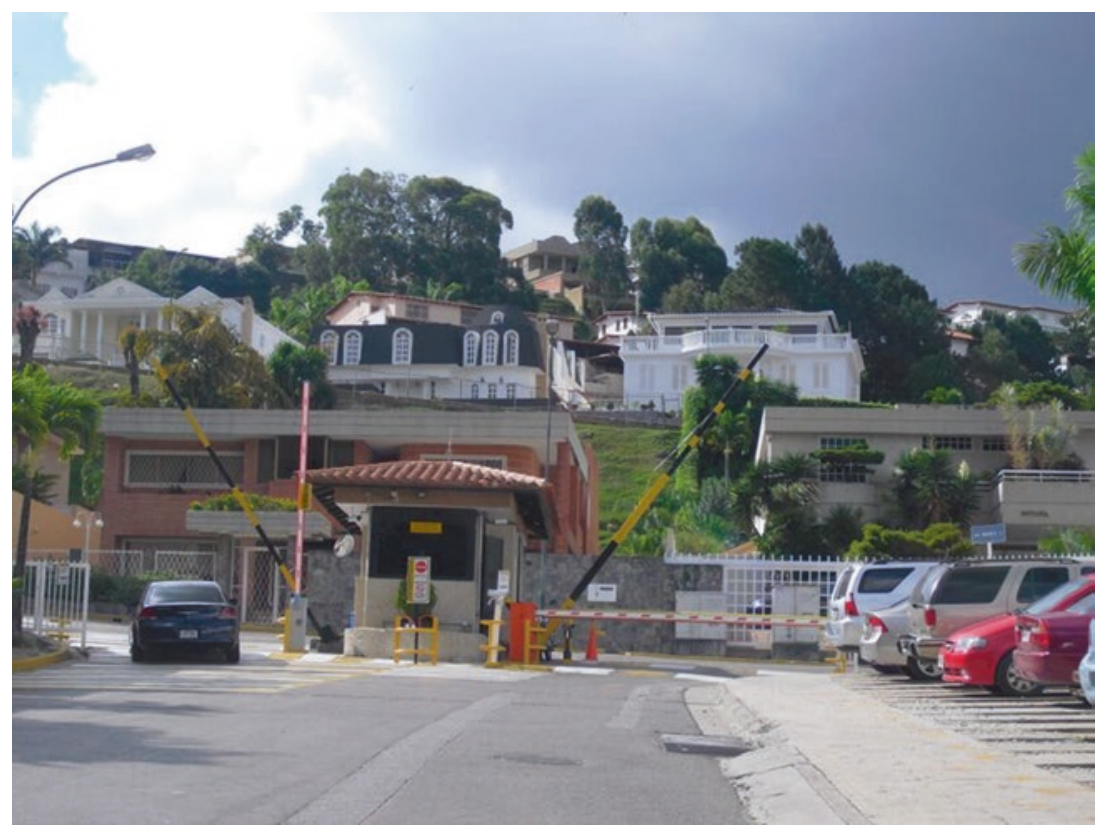

Photo 4.1 Private homes in Eastern Caracas. Photo by the author

neighborhood. Huge mansions were scattered along the road, many with garages that could fit five to six cars, and most of them surrounded by high gates and barbed wire. Many had security cameras, making us feel like intruders even though we had nothing bad in mind. The mansions had broad frontyard patios in marble and ceramic, well-kept gardens and lush vegetation. Swimming pools were hidden in the backyards. The cars that were parked in the front of these houses were all shiny and polished, most of them $4 \times 4-$ a necessary status symbol for anyone who can afford it. And there it was again; another replica of the White House. I just had to take a photo. So we passed the house on our motorbike one more time while I tried to take the picture as fast as I could, still worried that someone would see us and call the police.

For the next hour we cruised around the area. Up and down the hill, the gated mansions continued, one more luxurious than the next. At the end of the valley we encountered another huge private gated club, complete with several tennis courts and large green areas stretching up the hillagain there was no one in sight. And there was another shopping mall, 
with another "White House" on the other side of the road, and another exclusive-looking gated community that we didn't dare to approach. The cars that passed us were all shiny, new and expensive. Only a few times did we pass a camioneta, and those we saw had a sign announcing that they went all the way to Casalta 3-at the far end of the other side of town, where I lived. But the camioneta was not for the people who lived in El Hatillo, it was for their domestic servants, mostly women, but also a few men who were probably guards and gardeners. They were looking tiredly out of the window, all of them notably darker than the few locals we saw. My friend commented that a friend of his who worked as a delivery boy once had the door opened in this neighborhood by a woman that was dressed in a black-and-white domestic servant uniform as in the television soap operas, complete with the hair cap and everything. I didn't even want to think of how early you had to get up in the morning if you were to cross Caracas from a western barrio up to El Hatillo by bus.

In the afternoon, we went back to the shopping mall Los Naranjos. On the way up to the food court we passed two TV personalities. We sat down at an Asian restaurant, starving after the long trip. Next to us were two women and a teenage girl eating sushi. One of the women, probably in her thirties, was talking in a loud voice about her recent return trip from Miami and how the plane had been delayed from a stop-over in Panama and how her father had called the airline company to demand to know where she was. Three teenage boys were sitting at another table with a "fuck the world" expression on their faces, all dressed in trendy, expensive sporting clothes, fiddling with their Blackberries (another status symbol) and eating sushi. On the other side of the room a group of people had occupied two tables. They were all fair-skinned, well-dressed and self-confidently gesticulating - with the exception of one person around the table, the darker-skinned nanny that they had brought with them to occasionally hold one of the toddlers. So as to make it clear that she was not one of them, she was dressed in the kind of shirt that the women who work in kindergartens use - a blue overall with prints of dancing bears on. Her hair was up in a bun. The hair of the other women looked shiny and perfect as if it had just been done by the hairdresser. In the west of Caracas, the nanny could have been my next-door neighbor, or any woman in the street; here she stood out, the only one in the group with mixed-race features marked by a hard life, sitting quietly and with a bent back.

It was getting late. We got back on the motorbike again and slowly descended the long and winding road down to the middle-class area of El Cafetal. If I turned my head to the right, I could see Petare, perhaps 
some two kilometers away in air distance. Petare is said to be the largest shantytown in Latin America, located in Municipio Sucre, on the border between Distrito Capital and Estado Miranda. As a displaced pincushion it lay there, thousands of red brick ranchos and spiderweb-like telephone and electricity cables sprawling up the mountain right next to the otherwise wealthy sectors in the east. From Petare comes a steady stream of news reports of murders and robberies and houses that are falling apart when it rains, but it is also conveniently close to its richer neighborhoods and a source of labor for bars and restaurants, shops and services, domestic servants and private guards.

As we reach the highway and the border of the El Hatillo Municipality, there is a sign welcoming us back, in both Spanish and English. There is also a blue sign-apparently set up by the municipality-asking: "Is your vehicle insured?" It was probably a reminder for the good people of El Hatillo that they were now leaving the safe haven of their gates and guards, and entering the dangerous jungle that is the rest of Caracas.

The contrast between wealth and poverty in Caracas is glaring for any visitor. The physical features of Caracas, cramped into a narrow valley, make it even more evident. Paradoxically, when traveling on the highway from the international airport of Maiquetia, along the coast and then into the city of Caracas, one inevitably has to pass the enormous, sprawling shantytown hills of, among others, Gramoven, Carretera Vieja, El Limón and 23 de Enero. A friend of mine once said that rich people, rushing by in their SUVs on their way home to eastern Caracas, probably just close their eyes when they pass these communities, pretending they are not there. Maybe that is true. Or perhaps they do see them, but what they see is "the space of the others": something that doesn't concern them or is part of their life world.

But the two extremes of Venezuelan society, the opulent mansions in the east and the ramshackle ranchos (shacks) in the west, are like two sides of the same coin. People's lives on either side of town are bound together by a common past, shaped by the twists and turns of politics, history and life. As discussed in previous chapters, Venezuela was shaped by oil flowing into a society structured by its colonial past. If we can grasp the consequences this had on creating different social groups inhabiting completely different life worlds, we are one step closer to understanding the underlying conflict shaping political processes in the Chávez era. 


\section{Manifestations of Social Inequality}

Viewing the physical habitat as a surface expression of much deeper social histories and historical-political developments, the city-valley of Caracas is, more than anything else, a testament to the unequal distribution of riches and radical differences in life quality that characterize not only Venezuela, but also the entire continent. Deep poverty and overwhelming luxury are found side by side, as in most Latin American cities. This is nothing new, but rather a basic feature of the continent since colonial times. Latin America and the Caribbean is the region of the world with the highest levels of inequality, characterized by three main features: "[inequality] is high, it is persistent, and it reproduces itself within a context of low socioeconomic mobility" (UNDP 2010:19).

The continental shift to neoliberal policies in the 1980s dramatically exacerbated social inequalities. Contracted economies, a downscaling of the productive sectors of the economy with the subsequent contraction of job markets, de-regulation and privatization of basic services and the reduction of social spending all led to increasing poverty rates and more social inequalities. As part of this process of social disruptions and economic changes, a redrawing of spatial and social maps has been taking place in urban centers in recent decades. The essence of these recent urbanization processes are new forms of spatial segregation and social discrimination, whereby those who can afford it, that is, the middle and upper classes, increasingly withdraw from public spaces in favor of building "exclusive, fortified enclaves for their residence, work, leisure, and consumption" (Caldeira 2000:1).

Caracas is no different in this respect. Those who can afford it live in mansions, gated communities and closed-off condominiums, pass their leisure time in expensive private clubs, use private transportation, send their children to expensive private schools and use private medical facilities. Vacations are spent in the USA, preferably Miami, and in Europe, Aruba, the Dominican Republic, or other high-class destinations. These are possibilities and places that are inaccessible for the poor. As a consequence, there are few or no spaces left for public interaction between those at the bottom and those at the top of the class hierarchy. The predominant types of cross-class encounters are those between employer and employee, and service buyer and service provider. "The rich" know "the poor" only as their employees, security guards, maids, bartenders, 
waitresses and shop keepers. There are few or no arenas in which different social classes mingle and few or no spaces that are non-hierarchical or have the potential to transgress class boundaries. The only spaces where different social classes can potentially mingle are the shopping malls. Thus, paradoxically, the consumer capitalism following the de-industrialization that drove social classes even more apart is also the force uniting themon the surface at least.

\section{Stratified Media Spaces}

The increasing monopolization and privatization of media and communication further reduced spaces available for public debate and deliberation (Fernandes 2010:2), strengthening the domination of the worldview and the interests of the powerful. This is also the case in Venezuela, where the media, contrary to what the opposition and national and international media commonly claim, was overwhelmingly dominated by private actors also under Chávez's rule (Weissbrot and Ruttenberg 2010; BBC 2012; Sapiezynska 2017:207).

Mixing media ownership and political and economic interests in a manner that would in no way be acceptable in Europe, media moguls in Latin America, including Venezuela, hold an enormous power-not only in furthering their own interests, but also in defining perceptions of citizenship and society. It was only after Chávez came to power that dark-skinned, poor people became legitimate protagonists in Venezuelan media, through governmental and grassroots media (Schiller 2011). The private channels are still displaying predominantly white people, and if colored and poor people are portrayed, it is more often than not as fools, villains or victims in news reports or soap operas.

\section{Cleavages Revealed}

"Chávez destroyed the harmonious society that we once had," was one of the truisms repeatedly stated by Chávez's opponents. This statement can be taken as a testament to the affluent minority's lack of knowledge about the lives of the poor. As one female Chávez's supporter worded it:

They [the opposition/middle- and upper class] never knew anything about the living conditions in the rest of the society. They didn't have to use public transport because they had their own cars. They didn't need to use public 
hospitals because they were insured at private clinics. They didn't have to care about pensions or social security because they had money. They didn't have to worry about crime because they had their private security firms. They knew nothing about all this and they don't understand what is happening here because they don't understand the background for it. It is like Chávez once said: even if we placed the opposition on a pedestal covered with diamonds, they would still hate us.

Chávez's coming to power laid bare the existing cleavages in Venezuelan society, at the same time as these cleavages were exacerbated by the ensuing political struggle between different social groups and classes. As the Chávez government provided the poor and colored with a renewed status, self-confidence and visibility in Venezuelan society, deep-seated and racialized stereotypes and prejudices against "the poor" became highly accentuated among the whiter and wealthier. At the same time, government supporters framed their antagonism against the elites in politically charged terms, criticizing the middle classes for being "bourgeois" parasites as well as traitors of national interests. Underlying these conflicts were deep racialized tensions harking back to the country's colonial formation.

\section{The Salience of Race}

The issue of race is an under-communicated, yet omnipresent feature of Venezuelan society. "Here in Venezuela there is no racism," people sometimes told me. "Here we all mingle." Nothing could be further from the truth. From the blonde European-looking women in skimpy bikinis figuring on the ever-present propaganda posters for the beer brand Polar, to people's vernacular conception of beauty; from the overwhelming whiteness of private media celebrities, to the differences in skin color between people in pro-opposition marches and people in pro-government marches: skin color is a vehicle through which racial hierarchy and prejudices speak.

The hierarchicalization of people based on color and race in Latin America has deep historical roots dating back to the Spanish invasion of indigenous land, the import of African slaves and the political conquest and domination of the continent constituting the Europeans as the superior victors. The white Spaniards constituted themselves as a race superior to those of black and indigenous people: a belief that found support 
in religion, politics and scientific beliefs at the time (see Harrison 1995; Hoffman and Centeno 2003; Mullings 2005).

In the post-emancipation period, Venezuelan elites regarded blacks as inferiors because they were associated with their status as slaves, perceived of as a separate cast designed to work for the whites (Wright 1990:5). Hence, the elites did not consider themselves racist, but rather attributed their contempt for blacks to the fact that they were poor-a just socio-economic classification in the elites' eyes, rather than a racial categorization (Wright 1990:5). However, black and colored people held important positions among regional and national elites after Venezuela's independence in 1830. The lack of a strong central state allowed black and colored individuals to establish themselves as regional caudillos through using military might, and pardos (the term used to describe the racial amalgam of Europeans, blacks and Indians) were found in the federal agencies and military organizations (Wright 1990:10).

\section{The Myth of Racial Democracy}

In the 1890s, leading Venezuelan intellectuals talked about the need to "whiten the race" by encouraging the immigration of white Europeans, while blocking the immigration of non-whites (Wright 1990:2; Tinker 2009:133; Derham 2010:69). Attributing racial dispositions to genetic deficiencies (Derham 2010:69) they didn't perceive blacks and pardos as compatible with democratic self-rule, and advocated for a strong centralist government that they eventually found in Juan Vicente Gómez's regime (Wright 1990:10). Following Gómez's death in 1935, the subsequent heads of state took a more "open-minded" stance on the correlations between race and democratic inclinations, allowing Acción Democrática to form its party with a leadership drawing from mixed-race and middle-class groups. Moreover, Acción Democrática soon found alliances with pardos and blacks (Wright 1990:10), turning the notion of racial democracy into their official party ideology (Wright 1990:11). These changes were seen as threatening by the white elites, not necessarily because of the threat of color, but rather because of the threat of the mobilization and rise of the lower classes (Wright 1990:11). Immigration processes driven by the bourgeoning oil industry also raised a lot of controversy. Leading intellectuals were overtly concerned with the dangers 
of colored immigration, as the oil industry attracted workers both of North American, European, Asian and Afro-West Indian origins (Wright 1990:132-133).

\section{Disposable SaVages}

However, as Acción Democrática and COPEI consolidated their governance following 1959, racial democracy gradually became the dominant official ideology, sustained by a populist-nationalist hegemony. This provided the Venezuelan lower and predominantly colored classes with a legitimate position in the lower end of the social hierarchy during the Fourth Republic until the social breakdown in the 1980s. They were portrayed as el pueblo; "as virtuous, albeit ignorant, and therefore in need of guidance" (Coronil and Skurski 2006:199). This perception changed notably as social conflict increased in the 1980s and 1990s. The escalating tensions between the elites and the poor transformed el pueblo from a noble mass to an unruly mass that threatened the civilizatory harmony of the nation (Coronil and Skurski 2006). This shift brought out in the open the underlying colonial racial templates associating color with primitivism and inherent inferiority. As Coronil and Skurski demonstrate through a minute analysis of the public reactions to the Amparo massacre in 1988 and el Caracazo in 1989, both instances "made salient suppressed conceptions of the poor as disposable savages" (Coronil and Skurski 2006:123).

\section{The Poor in Velvet Seats}

When Chávez emerged on the political scene during the attempted coup in 1992, Venezuela's self-imagery as a racial democracy with a pacted class-compromise had been thoroughly shattered. When he a few years later ran as a presidential candidate, the poor saw in him the possibility to finally be represented by someone who didn't only understand them, but who also looked like them. With his mixed-race physical features and poor background, Chávez turned himself into the first statesman to not only speak for the poor, but also with them. As his presidency evolved, the poor and colored became increasingly visible in those public spaces that had been previously controlled and defined by the middle- and upper classes. Suddenly, they had access to media, to politicians, and to other arenas that were previously forbidden territory. Many times, people told me of how 
the pompous concert hall, Teresa Careño, in downtown Caracas, with its soft, red velvet seats, had suddenly become accessible to the poor classes. Not only was it being used for political meetings, but discount tickets were also sold for cultural events such as concerts, plays and operas. Previously, this concert hall was the exclusive space of the elites.

And never before had the poor classes been able to enter the offices of government ministries or of the National Assembly to directly talk to the decision-makers. Suddenly, the poor were at the center of the political agenda, and they could meet with politicians and even solicit their presence in meetings organized by the popular sector. No longer did they have to bow to power and privilege. The stigma of poverty had been removed and converted into a symbol of pride, strength and virtuousness. Gerardo, a young man in his late 20 s once told me of when he used to work as a delivery boy. Equipped with a motorbike, he ran errands for a company around town-a common occupation where mail services are highly deficient. He always felt so ashamed and intimidated when he walked into the nice office buildings. The employees would disapprovingly look at him and his grimy face covered with traffic dust. "Things had changed," he said. Poor people no longer felt ashamed.

For the middle and upper classes, who were used to having monopoly over defining social and political hegemony, this immense social and political change came as a shock. Not only was the country suddenly ruled by colored people that, in their eyes, were not capable or entitled to rule a country (Fernandes 2010:118), but all of a sudden poor people were imposing themselves across social and political spaces and claiming power and privileges. The wealthy homeowners in eastern Caracas complained that their maids and gardeners had become too demanding and assertive. As political tensions rose, the class and race cards were increasingly played by the wealthy to demonstrate their disgust with the government and its followers.

\section{Monkeys, Marginals and Mobs}

The racial dimension of their political disdain was evidenced in the frequent portrayal of Hugo Chávez, and other colored political leaders, as a monkey in cartoons. Moreover, government opponents frequently referred to Hugo Chávez as mico mandante. The expression is derived from mi comandante (my commander) - an expression Chávez's followers often used when referring to him, while mico is a small monkey. The 
expression thus translates to "monkey in charge." Some years back, the US embassy in Caracas hosted a party where the guests were entertained with a puppet show portraying Chávez as a gorilla. Colin Powell, the US foreign minister at the time, was not amused-perhaps for obvious reasons-and publicly reprimanded the embassy (Ali 2013). Monos (monkeys), hordas (hordes), chusma (lowlife, scum), turba (mob), marginales (marginals), ordinarios (simple) and lumpen (poor, vulgar, brute) were other expressions frequently used by government opponents when referring to supporters of the Chávez government. Another expression was that the government's supporters have a bozal de arepa (muzzle of arepa). The muzzle full of arepas is in this case used to suggest that the poor were silenced and fooled by government handouts. Another derogatory expression used to refer to poor people in general is tierruos, which comes from tierra (soil). The expression harks back to when the streets in the barrios weren't asphalted and a barrio inhabitant could be recognized because of his or her soil-covered feet upon entering the city center. Another term is pata en el suelo, simply meaning "hoofs on the ground," referring to a person who cannot afford to buy shoes and thus walks barefoot.

\section{Civil Society And Mobs}

Scholars have drawn attention to how both oppositional groups and affiliated private media consistently portray themselves as "civil society groups," whereas government supporters are described as hordes, mobs and scum (Fernandes 2010:118; Duno-Gottberg 2011). As Duno-Gottberg writes about how the private Venezuelan media portrayed the popular mobilization during the 2002 coup: "As a mob, they were undifferentiated, faceless" (Duno-Gottberg 2009:160). They were cast as barbaric, irrational and violent, and deprived of political rationale (Duno-Gottberg 2009:160). The "civil society" of the middle and upper classes in contrast, represented order, reason, modernity and prudence, exercising their political agency in manners consistent with legitimate middle-class citizenship in modern capitalist societies.

The imagery of the poor as a mob can also be found in a more recent story. This was experienced first-hand by a middle-class friend of mine. During the 2014 demonstrations and guarimbas (violent riots) carried out by oppositional middle-class youth and students, there were fears 
among middle-class citizens that government supporters would come to their neighborhoods to retaliate. At a meeting in one of the gated condominiums close to the city center, they were discussing how to defend themselves if their gates were attacked by furious barrio dwellers. The suggestion that many of the residents found the most attractive was that they would gather at the roof of the building and throw boiling cooking oil down at the invaders. The hordes never came.

\section{The Ideology of the Resentful}

Another recurrent middle-class template of Chávez's supporters is that they were resentidos (resentful) toward the rich, wanting what was not rightfully theirs at the expense of "hardworking" people. It is a common perception among the middle and upper classes that the poor are poor because they are lazy and incapable of "superarse y salir adelante" [improve themselves and move forward]. In contrast, the rich have what they have because of their hard work, and not because of inherited privileges, their birthed social position, or structural inequalities. Chavismo appealed to the poor, according to this perception, because it gave them handouts and fed upon the hatred toward the rich. For example, an op-ed in the Venezuelan daily newspaper El Universal, titled "La ideología del resentido" [the ideology of the resentful], read: "As a central strategy, the Señor President [Chávez] appeals to the abandonment of the marginal, making him feel valued and to a great extent feeding their hatred towards the richest" (Guerra 2009, author's translation from Spanish). Guerra's initial opinion of Chavista activists was that they were:

individuals without any style whatsoever ... lacking of any apparent education, and with a threatening and ragged expressions. In their slogans they emulate curses against opponents, defending a revolution they don't know, with hatred as a banner, vengeance as a motor and as principles and values .... They use weapons of all kinds against any march or convocation of the existing "oligarchy" and destruction is left in their wake, without any remorse whatsoever, nor basically any belief at all. (Guerra 2009, author's translation from Spanish)

The author then modified her view of Chávez's supporters, recognizing that among them are both educated and even intelligent people-though lacking "emotional intelligence." Now she has come to believe that being 
a Chavista is not a matter of education or money, but rather a matter of people who cuddle for some kind of traumatic experience of poverty or abandonment in life.

The views expressed in this op-ed eloquently sums up the different perceptions circulating among the middle and upper class about Chávez's supporters and poor people in general. Structural explanations of poverty have little resonance in this scheme. In line with conventional neoliberal individualistic ideology-not least social ideologies prevalent in the USA-it is believed that people have to accomplish themselves by their own efforts, and that poverty comes from inherent traits-laziness, passivity, sloth, resentment and envy. In this perspective, the Chávez government's redistribute efforts simply amounted to a strategy to win votes through cuddling up to a culture of poverty (Lewis 1966).

\section{Institutionalized Prejudices}

Nancy, a young and ambitious woman in her early 30s working as a teacher in a private school in the middle-class neighborhood of Altamira, frequently told me of how her mainly white middle-class colleagues and the children's mothers talked about government supporters and poor people in general. Nancy's school catered mainly to wealthier children, and Nancy had to be careful to disguise her political sympathy toward the government. In the stories of her work environment, everyday racism and class prejudices were abundant, evidencing that in spite of the political removal of the stigma attached to being poor and colored within the socio-political sphere of the government and its supporters, social spaces dominated by the middle and upper classes remained unchanged. One of the episodes that she recalled was a conversation she had with the former principal at her school, who nodding toward a colored pupil, said with barely hidden contempt: "Before, we didn't use to have negros here ... it's not like I am a racist, but you know...."

The Chávez government obliged private schools to admit pupils from the disadvantaged sectors of society. However, according to Nancy, schools did what they could to avoid it, or at least her school did. Nancy recounted that the school psychologists responsible for admissions had told her that they singled out those applicants whose parents didn't have a professional degree because "surely they cannot pay." They also singled out those children whose parents were likely to be Chavista (education, 
color and address being what gave them away) "because they would only create trouble." Nancy herself had never revealed that she was a Chavista. "They would kick me out, without a doubt. They would find any excuse to sack me," she said. "I think there are other teachers there who are Chavistas as well, but we never talk about it. We just find a way not to say anything if the other teachers (supporting the opposition) say something," she added. Nancy herself grew up in dire poverty in a shantytown in western Caracas, but through her mother's and her own enormous efforts and sacrifices, she managed to graduate as a geography and history teacher. She has a fairly light complexion and takes great care of, and spends a large portion of her income on, her appearance (hair, skin and clothing) so as to not evoke the scorn of her pupils. That was why she managed to get the job in the first place and also managed to keep it. She recalled that a substitute teacher with darker skin, curly hair revealing her African ancestry and clothing that revealed her less affluent background had been bullied so much by her pupils that she had resigned after a week.

\section{Class Resentments Reversed}

Derogatory labeling of the middle and upper classes also seeped into the political vocabulary of the government and of the popular classes. The commonly used term esqualido as a substantive for opposition supporters emerged in the midst of the political polarization after Chávez's election. Esqualido derives from the word squalid, or to be without morals, values and social conscience. Sifrino is a common term for middle-class opponents, referring to a person that is materialistic, snobbish, superficial and preposterous, and has questionable values and a lack of social conscience. It is worth noting that sifrino is not only used as a class attribute, but can also be used of a person that has a snobby appearance and certain consumption preferences. People from a humble background can also be called sifrinos if they try to be snobbish in their behavior or consumption (see Chap. 8). Oligarchia (oligarchy) and burgués (bourgeois) are commonly used class ascriptions within the leftistMarxist vocabulary.

Burgués is similar to sifrino while oligarchia is used to describe economic interest groups that are using covert and/or violent strategies to maintain their power and privileges. Similarly, golpistas (coup-mongers) 
and facistas (fascists) refer to the opposition's attempts to undermine the Chávez government with any means necessary, in particularly referring to the 2002 coup. Vendepatria (sellers of the fatherland) refers to the perceived attachment that the opposition/oligarchy has to external interests and their lack of loyalty to the interests of their homeland, both economically and spiritually. It is often said that the Venezuelan upper classes have their spiritual home in Miami. Not only was Miami the favored destination (and to a large extent still is) for middle- and upper-class shopping sprees during the Venezuela Saudita period of the 1970s, but it is also home to a large expat community that resembles the Cuban one in its virulent hostility toward Chávez and his supporters.

The degree of hostility between opposition and government supporters has changed with shifting political junctures. In the years following the coup in 2002 , levels of hostility ran particularly high, and families and friends reportedly became bitter enemies over political differences. The conflict levels have also hardened in the aftermath of Chávez's death and the election of Nicholas Maduro in 2013.

\section{Chávez, El Presidente and El Pana ${ }^{1}$}

Chávez's weekly Sunday shows, Aló Presidente, were undoubtedly crucial in shaping Chávez's relationship with his supporters. The live transmissions were filmed from across the country, as Chávez was touring the nation, visiting communities and inspecting government projects. There, he combined political analysis with historical lectures, anecdotes, jokes, songs, popular education and on-the-spot interaction with the audience. His ability to talk without a script was only comparable to that of Fidel Castro, and his pedagogical skills allowed him to present relatively dry policy topics in a way that captured even the most politically illiterate audience. Through these programs and other public appearances, people felt that they got to know Chávez the person. He became a man in the flesh, who was open about his feelings, apologized for his mistakes and shared generously from his personal life.

While it is tempting to characterize this form of communication as a merely populist strategy, Chávez's mass appeal cannot be reduced to a question of charisma, manipulation and demagoguery (Hellinger 2001:5). According to Alejandro Moreno, a Salesian priest and social psychologist who has lived in one of the barrios of Caracas for a long time: "What is important is not what he speaks but what speaks inside 
him. In him speaks the convivial relations of popular Venezuela, of convivial man ... an elderly woman expressed it very well: 'for me, it's like my own son is president" (Hellinger 2001:5). The intimacy that this elderly woman felt toward Chávez is telling of the general sentiments that he incited among his followers. Chávez appeared as a friend, a son or a neighbor. He was what Venezuelans colloquially call a jodedor, a person that doesn't take himself too seriously, who loves a good banter and knows how to tell a good story - the ideal person to have a beer with on your door step on a Friday afternoon. He was the anti-thesis to the kind of slick politicians that staged photo-shoots with the poor, kissing babies and squeezing the hands of old ladies trying to appear sympathetic to the plight of the disenfranchised. Chávez had been poor himself, and he was, as he once said describing his relationship with el pueblo, like a "fish in the water" (Ellner 2003:146).

\section{SONS AND DAughters OF Bolívar}

Yet, while Chávez was recognized as the "maximum leader" in that historical moment, his followers were not merely passive recipients of his political directives. When Chávez announced a new political vision or a significant new strategy, it would be subjected to analysis among activists. By highlighting people's power and emphasizing el pueblo as the sovereign, the poor felt enabled to appreciate and claim their own past, giving strength to a process of social organization from below. Like a housewife and activist from Catia in her 40s said to me as I was interviewing her in La Casa de Poder Popular (the house of people's power) in Propatria:

We, the Venezuelans, since this revolutionary process that El Comandante Hugo Chávez Frias is leading, is submerged in a profound knowledge and recognition of our history. For years, the social movements were treated as hordes, as unruly negros, as ignorant ... as uneducated, as uneducated without a fatherland ... when el pueblo has gathered and poured out in the streets, to do revolution, to break the chains ... it has taken place because that has been moments when el pueblo have been conscious of why they are taking to the streets...

This statement is representative of how "common people" articulated their newfound political subjectivities. "Bolivarian discourse," shared 
by housewives new to politics, long-term activists, and politicians alike, underscored that Chávez's greatest achievement was to enable the poor to appropriate a cultural, social and political space that was rightfully theirs for the first time in Venezuelan history.

What was seen as rightfully theirs in this context was also a quest for restoring "true" Venezuelanness and national dignity. As Rosa, an ardent Chávez's supporter in her 60s, worded it:

I have always rebelled against everything that goes against my country, not only now, but all my life, and like I say to people ... many people say to me in a condescending way, ah, you are a Chavista. And I say to them, hold on a minute, I am not a Chavista, I am venezolana, Bolivariana and revolucionaria (Venezuelan, Bolivarian and revolutionary), that is my way of thinking. And do I love Chávez? Yes, I do, because that man has done for this country what no one else has done.

To understand the meaning of Rosa's words, it is important to capture the national mythology surrounding Simón Bolívar, and the way that he has become both mythologized and reinterpreted into a Bolivarian narrative. In simple terms, Simón Bolívar embodies the historical quest for national sovereignty and social justice. The struggle that he was fighting against the Spanish colonizers equals the contemporary struggle against foreign domination and exploitation. One of Bolívar's most famous quotes is: "The United States seems destined by providence to plague Latin America in the name of liberty." 2 Accordingly, his master thought was the creation of a confederation of neighbouring countries called Gran Colombia which could constitute a counter-hegemonic force against North American dominance. Within the Bolivarian narrative, the Bolivarian process, leaded by Hugo Chávez, was the continuation of Bolívar's quest for independence. Bolívar was born into oligarchy, but turned against his own as he joined forces with freed slaves and peasants against the Spanish conquistadores. Per the Bolivarian narrative, his fight for the liberty of el pueblo was paralleled to the fight against the contemporary oligarchy in the name of the liberty and dignity of the popular sectors. Within this interpretative scheme, both the oligarchs of Bolívar's time and today's oligarchs are betraying Venezuela because they have since long been allied with, and benefited from the alliance with foreign exploiters at the nation's expense.

Often, prose is better equipped than academic analysis to communicate deep-seated national sentiments. I will therefore quote the lyrics of the folk singer, Alí Primera, that express the emotions associated with Bolívar. 


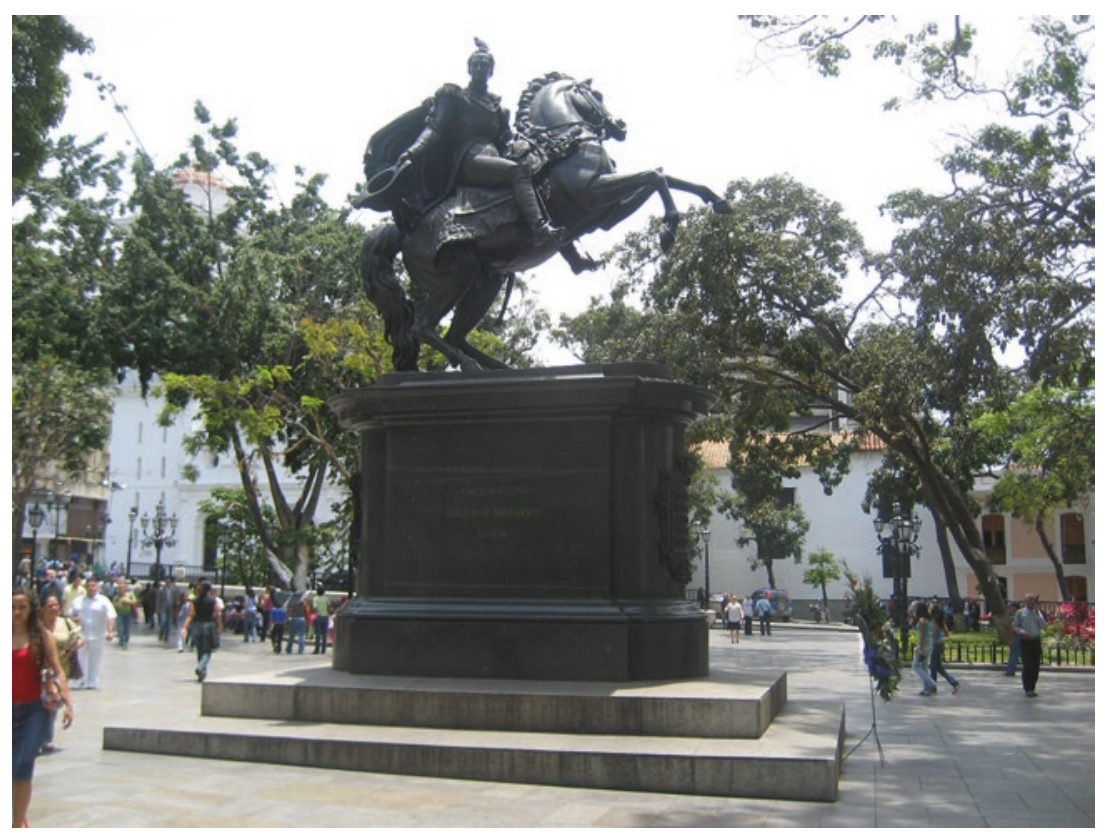

Photo 4.2 The statue of Simón Bolívar at Plaza Bolívar, downtown Caracas. Photo by the author

This is one of Primera's most famous songs, titled Sangueo para el Regreso (drumbeat for the return) ${ }^{3}$ :

El pueblo is wise and patient the elders are saying that when the guacharaca is singing ${ }^{4}$ they know how to calculate time

They say that the time is coming be alert, for when we will be happy Bolívar left yesterday but he is about to return

$$
\text { Let's go there }
$$
let's go meet him

They say that Bolívar is coming filled with rage and courage inside 


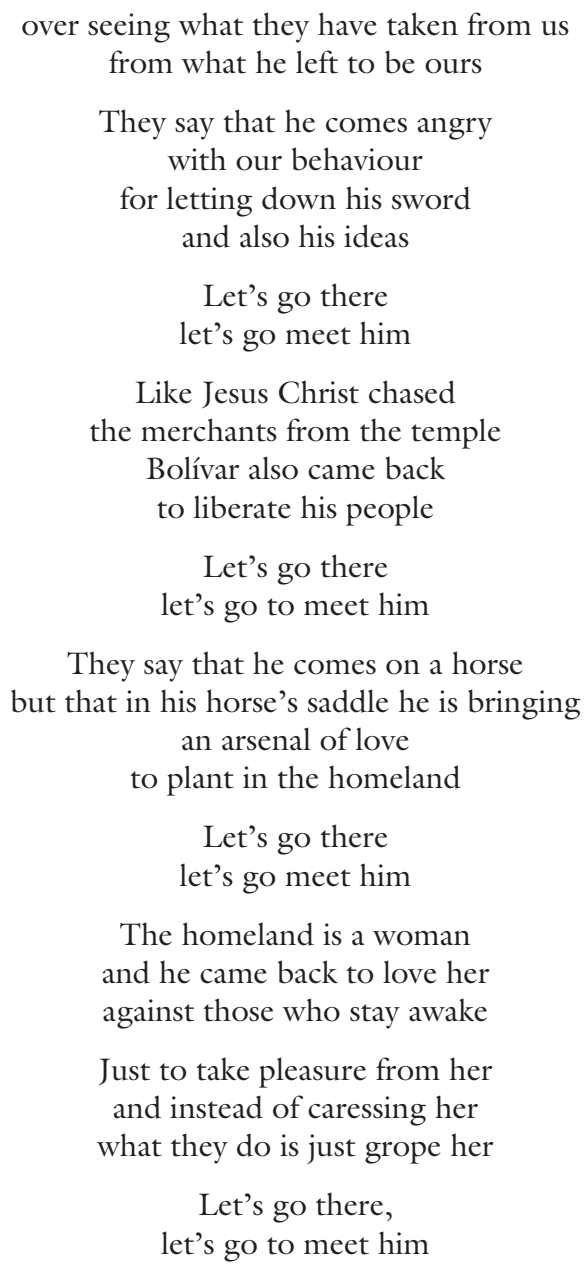

In this poem, Venezuela is referred to as a woman that has been exploited and pillaged by greedy "merchants," and el pueblo is portrayed as having betrayed the struggle and the legacy that Bolivar left them with. However, the poem also indicates that he will return to embrace them and continue the struggle. As an associated digression, it is worth recalling Pablo Neruda's poem "A Song for Bolívar," in which Bolívar says: "I wake up every hundred years when the people awake." The imagery of Bolívar looms large in Latin American leftist political consciousness, because per 
their political-ideological historical timeframe, the struggle for independence and liberty that Bolívar started has never been completed. When we now revisit Rosa's pledge to be venezolana, Bolivariana and revolucionaria we can better appreciate the multi-layered meaning of that statement, whereby she aligns her support for Chávez with an ongoing struggle for reconquering the nation's sovereignty and integrity.

Often, Latin American political symbolism is misunderstood by foreign observers. Drawing on more pathos and more mystique than what is usually allowed in Western political discourse, it is often interpreted as anti-modern and detrimental to political rationality. Chávez's evoking of Bolívar in his political discourse has occasionally been chided as a cultlike manipulation of national symbols. However, while these symbols and associations are central to the Bolivarian ideology, they can also be read as interpretative vehicles for articulating historical trajectories, political ideologies and social identities rather than as archaic narratives steeped in magical realism (but see Michelutti 2017).

\section{Caudillismo and Chávez's Charisma}

While, throughout this and in Chap. 3, I have sought to describe popular mobilization through the political and historical experiences of the popular sectors, it is also important to recognize the legacy of caudillo leadership in Latin America's political culture and the ways in which Chávez has been associated with this historical interpretation of leadership and rule.

The imagery of the caudillo originated from Latin America's tumultuous political history after colonialism, which revolved around regionalist and centralist struggles whereby military strongmen were "rising from power and falling from it, to be replaced by new seekers after power who rose and fell in turn" (Wolf and Hansen 1972:205). The caudillo is often envisioned as a brave, fearless, strong and armed man "on horseback," gaining power through his personal ability to muster followers through coercion, charisma or political visions, or a combination of the three. As Wolf and Hansen show, caudillismo has to be understood as a product of colonialism and post-colonial rule, forming certain configurations of political institutions, economic relations, territorial divisions, social stratifications and military power (Wolf and Hansen 1972:216-223). The historical role of the caudillo in political life rests on a particular form of Latin American personhood molded through machismo: independent, brave and 
with a dose of cruelty, dominant (both toward women and other men), shrewd and savvy (Wolf and Hansen 1972:224).

The imagery of caudillismo as a "one-man/strong-man rule" is often invoked in Latin American politics as proof of the fallback to "primitive" politics of the past. A Google search for Chávez + caudillo generates around 426,000 hits, evidencing the extent to which Chávez became associated with this political style. Certainly, Chávez's personal style resonated with the historical strong-man image-not least because of his military background. Both in charismatic terms and political terms, his government was very much centralized in the imagery of Chávez as the one man that had the strength to command the political change that the Bolivarian process entailed. Moreover, by invoking the figure of Bolívar, a larger-than-life icon of the "benevolent" caudillo in Venezuelan national mythology, the imagery of national salvation by the hands of one single man became even more bolstered.

However, as the discussions above have shown, people's relationship (real and imagined) with Chávez was both complex and nuanced. His public persona and relationship with "the masses" certainly had certain messianic and "caudillistic" qualities, but if we give that too much explanatory weigh, we lose out of sight people's own life histories, social identities and political agencies both prior to and after the arrival of Chávez. Just like the concept of "populism," "caudillismo" provides for a thin explanation when confronted with the complex reality of how people themselves related to Chávez and the Bolivarian process.

In this and the foregoing chapter, I have sought for a thick description (Geertz 1973) of people's relationship to Chávez and the Bolivarian process, while at the same time addressing the deeper origins of the political polarization that flared up in Venezuela after Chávez's arrival to power. In the chapters that follow, I will turn my attention toward the way in which people's emerging political identities and agencies were enacted in the context of everyday popular politics. Commentators frequently grouped all of Chávez's supporters into one and labeled them Chavistas. From an emic point of view, this is a mistake. While some people self-identified as Chavistas-meaning that their political loyalty and beliefs were founded in the figure of Chávez (also in the aftermath of his death)-others were careful to emphasize that they were 
not Chavistas. Rather they underscored that their support for Chávez's political project rested on the basis of a shared conviction of the necessity of social change and political struggle. The majority of Chávez's supporters looked at state politics with a critical eye, and their support for the government was not unconditional. Most activists were careful to underscore that it was not "Chávez's revolution," but rather a popular revolution whose success was dependent on people's capacity to appropriate the political space that had been opened up through the Chávez government. At the heart of this struggle was the articulation of popular power through grassroots activism and community organization. Chapter 5 starts with a reflection on how we may best understand community politics in the context of the Bolivarian process, followed by a minute examination of a case of long-term community mobilization in the Parish of 23 de Enero.

\section{Notes}

1. Pana is an informal Venezuelan word for "buddy" or "pal."

2. In Spanish: Los Estados Unidos parecen destinados por la Providencia a plagar la América de miserias en nombre de la libertad.

3. Author's translation from Spanish. Sangueo is a verb referring to the sound of tambores, African drums, and it is therefore not easily translated. Original lyrics can be found at http://www.musica.com/letras.asp?letra= 1093256.

4. The guacharaca is a small parrot that only sings at certain hours of the day.

\section{BiBLIOGRAPHY}

Ali, Tariq. 2013. Tariq Ali: Hugo Chávez and Me. The Guardian, March 16. http://www.theguardian.com/world/2013/mar/06/hugo-chavez-andme-tariq-ali. Accessed February 20, 2017.

BBC. 2012. In Depth: Media in Venezuela. www.bbc.co.uk, October 3. http:// www.bbc.co.uk/news/world-latin-america-19368807. Accessed February 20, 2017.

Caldeira, Teresa. 2000. City of Walls. Crime, Segregation, and Citizenship in São Paulo. Berkeley: University of California Press.

Coronil, Fernando, and Julie Skurski. 2006. States of Violence. Ann Arbor: University of Michigan Press.

Derham, Michael. 2010. Politics in Venezuela. Explaining Hugo Chávez. Oxford, Bern, Berlin, Bruxelles, Frankfurt am Main, New York, Wien: Peter Lang. 
Duno-Gottberg, Luis. 2009. Social Images of Anti-Apocalypse: Bikers and the Representation of Popular Politics in Venezuela. Contracorriente 6 (2): $144-172$.

- 2011. The Colour of Mobs. Racial Politics, Ethnopopulism, and Representation of the Chávez Era. In Venezuela's Bolivarian Democracy. Participation, Politics and Culture under Chávez, ed. D. Smilde and D. Hellinger. Durham and London: Duke University Press.

Ellner, Steve. 2003. The Contrasting Variants of the Populism of Hugo Chávez and Alberto Fujimori. Journal of Latin American Studies 35 (1): 139-162.

Fernandes, Sujatha. 2010. Who Can Stop the Drums? Urban Social Movements in Chávez' Venezuela. Durham and London: Duke University Press.

Geertz, Clifford. 1973. The Interpretation of Cultures. New York: Basic Books, Inc.

Guerra, Natacha. 2009. La ideología del resentido. El Universal, February 13. http://www.eluniversal.com/opinion/090213/la-ideologia-del-resentido. Accessed February 20, 2017.

Harrison, Faye. 1995. The Persistent Power of "Race" in the Cultural and Political Economy of Racism. Annual Review of Anthropology 24: 47-74.

Hellinger, Daniel. 2001. Tercermundismo and Chavismo. Revised version of paper delivered at Meeting of the Latin American Studies Association, Washington, DC, September 2-8.

Hoffman, Kelly, and Miguel Angel Centeno. 2003. The Lopsided Continent: Inequality in Latin America. Annual Review of Sociology 29: 363-390.

Lewis, Oscar. 1966. La Vida: A Puerto Rican Family in the Culture of Poverty. San Juan and New York. New York: Random House.

Michelutti, Lucia. 2017. "We Are All Chávez": Charisma as an Embodied Experience. Latin American Perspectives 44 (1): 232-250.

Mullings, Leith. 2005. Interrogating Racism: Toward an Antiracist Anthropology. Annual Review of Anthropology 34: 667-693.

Sapiezynska, Ewa. 2017. The Media and Power in Postliberal Venezuela: The Legacy of Hugo Chávez for the Debate on Freedom of Expression. Latin American Perspectives 44 (1): 199-214.

Schiller, Naomi. 2011. Catia Sees You: Community Television, Clientelism, and the State in the Chávez Era. In Venezuela's Bolivarian Democracy. Participation, Politics and Culture under Chávez, ed. D. Smilde and D. Hellinger. Durham and London: Duke University Press.

Tinker, Miguel S. 2009. The Enduring Legacy. Oil, Culture, and Society in Venezuela. Durham and London: Duke University Press.

UNDP. 2010. Acting on the Future. Breaking the Intergenerational Transmission of Inequality. The Regional Human Development Report for Latin America and the Caribbean 2010, UNDP, United Nations. http://hdr.undp.org/en/content/acting-future. Accessed February 20, 2017. 
Weissbrot, Mark, and Tara Ruttenberg. 2010. Television in Venezuela: Who Dominates the Media? Center of Economic and Policy Research. http://cepr. net/documents/publications/2010_12_venezuela_media.pdf. Accessed June 11, 2017.

Wolf, Eric, and Edward Hansen. 1972. The Human Condition in Latin America. New York, London and Toronto: Oxford University Press.

Wright, Winthrop. 1990. Café con Leche. Race, Class and National Image in Venezuela. Austin: University of Texas Press.

Open Access This chapter is distributed under the terms of the Creative Commons Attribution 4.0 International License (http://creativecommons.org/licenses/ by $/ 4.0 /$ ), which permits use, duplication, adaptation, distribution and reproduction in any medium or format, as long as you give appropriate credit to the original author(s) and the source, provide a link to the Creative Commons license and indicate if changes were made.

The images or other third party material in this chapter are included in the chapter's Creative Commons license, unless indicated otherwise in a credit line to the material. If material is not included in the chapter's Creative Commons license and your intended use is not permitted by statutory regulation or exceeds the permitted use, you will need to obtain permission directly from the copyright holder.

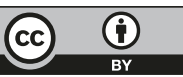




\section{Contested Community Politics}

Every night throughout the week, community meetings are taking place across Venezuela: at plazas, in the street, in a basketball court, at the neighborhood corner, at the local school or in whatever space available. Mostly they meet at 7 or 7:30, between dinner time and bed time, but due to people's notorious habit of showing up too late the meeting seldom starts on time. Often they are sitting on plastic chairs, or they are standing in a disorderly circle. More often than not, the majority of the participants at the meeting are women. Sometimes they have a child or a toddler with them. The spokesperson for the executive unit of the communal council will, if present, most often lead the meeting. If not, it will be led by one of the other spokespersons, or the person with the most informal authority.

What the meeting is about varies widely. Sometimes it is a citizen assembly, where the whole community is urged to show up because some important information has to be discussed, elections have to be invoked or binding decisions have to be made. The meeting is normally announced with hand-written posters around the neighborhood a few days ahead. The poster usually lists the time, place and agenda for the meeting, and ends with the word asiste! (attend!) followed by various exclamation points.

Sometimes it is just a meeting for the spokespersons in the communal council. The topics of the meetings depend on what stage of the work they are on. It can be that they are recently elected and have to register with the 
state institution Fundacomunal in order to be legally constituted. Perhaps they are having trouble opening a new bank account. Perhaps they have just received the message from a state institution that their project for fixing the pavement or for repairing houses has been approved. Or perhaps they are having problems with the state institution in getting their project approved.

Sometimes the voceros will have some kind of conflict with other members of the community, and fights will erupt. Sometimes practically no one shows up and the voceros that are present will be frustrated with the apathy that their fellow neighbors demonstrate. Sometimes there will be political discussions, but more often than not, the practical challenges are the most important. Often one or more of the voceros have spoken with someone in a state institution or assisted a seminar, forum or workshop, passing on whatever information they got. Sometimes there will be a representative from the state institution present to give them some information and answer questions. Sometimes the atmosphere will be tense and quarrels will erupt, or there will be optimism and hope. During the meeting, people will play with their mobile phones, smoke a cigarette and smaller discussions will frequently start within a smaller group until someone yells "one discussion, one discussion!" Sometimes it seems as if the meeting will never end and that the discussions will just go on and on. And then, suddenly the meeting is over, time and place for next meeting is agreed upon and most people rush home, while some stay behind and talk in small groups.

Seen from a bird's-eye view, "social change" or "political struggle" or "social policy reform" often remain abstract concepts, because we are unable to fathom the actual real-life dynamics that shape the unfolding of events. In the case of Venezuela, radical social policy reform took place in parallel with the formation of new modes of grassroots organization and grassroots involvement in state politics. These multiple processes of change threw up a host of unexpected social and political dynamics that can only properly be understood through a keen ethnographic attention to detail. To that end, I will focus on one particular case in this chapter, which concerns grassroots mobilization for the building of a state hospital in the parish of 23 de Enero. Through this case, I hope to reveal two important dimensions of popular politics and state-grassroots interaction during the Bolivarian process. Firstly, I will show the complexities 
and nuances that circumscribe ideas and practices constitutive of "community," or "grassroots mobilization." Indeed, it will become clear that barrio communities are heterogeneous social landscapes composed by a diversity of differently positioned social actors, different social identities, networks and organizational formations. If we get a proper grasp on these complexities, we are better equipped to understand not only the richness of grassroots mobilization that evolved during the Bolivarian process, but also the inherent challenges of rolling out social policy reforms through bottom-up participation. Moreover, as a second point, the case illustrates the opaque dynamics characterizing the Venezuelan state and bureaucracy, and the multiple strategies deployed by people in popular sector communities to make it more responsive. Seen together, this case provides a solid platform for our continuous explorations in subsequent chapters into how the Venezuelan state was sought transformed both from the inside and from below, and the numerous challenges and contradictions that this process implied.

\section{UNDERSTANDING “COMMUNITY”}

Within the Bolivarian political discourse, la communidad (the community) became a key idiom through which popular sector neighborhoods and social movements constituted themselves as collective political subjects, as well as the idiom through which local conflicts and differences were negotiated. Vested with particular rights and responsibilities as well as certain social attributes, the concept of la communidad became a potent signifier in both political and everyday discourse reflecting the legitimization of "the local" as a sovereign space and of el pueblo as a political community. Simultaneously, "the community" was constituted as the legitimate recipient for the redistribution of oil wealth through collective consumption. Rather than individual "drops of oil," social welfare, and hence social justice, had to come about through "collective solutions to collective problems," as one activist worded it.

"The community," in its various forms of organization, was also ideologically defined as the legitimate representation of popular interests and agencies in the eyes of the state. This view was constantly reinforced in political discourse, and supported by a range of legislations, resource allocations, policies and reforms aimed at increasing popular sector welfare through state-community co-operation. The role of the state was to support community initiatives based on the notions of soberania popular (popular sovereignty) and el poder constituyente (constitutive power) as 
provided for in the constitution (see Valencia 2015:56-63 for a thorough analysis of the institutionalization of popular power).

The struggle for a new political model of inclusive citizenship is, in Bolivarian discourse, coined as una democracia participativa and protagónica. While the first part of the expression is easily translated to "participatory democracy," the word protagónica (henceforth, protagonic) needs some clarification. It refers to a citizen's right not only to participate in pre-established frameworks designed from above, but also to be a real actor taking the initiative and lead in public affairs. This signalizes a qualitative difference from "only" participatory politics.

A participatory and protagonic democracy was often contraposed to a representative democracy, which was cast as a limited form of democracy reducing participation to the act of voting. For example, in a 1999 speech, addressing a constitutional referendum, Chávez said: "[ la democracia participativa and protagonica] is the restoration of democracy, but a real democracy, the participatory democracy, the democracy which consults" (Aponte Moreno 2008:19, author's translation from Spanish).

Participatory and protagonic are terms which were embraced by people, being a source of pride and evidence of the process of democratic deepening that Venezuela was undertaking. However, participation was not only conceptualized as inclusion in the spheres of formal politics. Rather, it was conceived of as a new mode of citizenship that implied taking an active and conscious role in all ambits of society. This is for example how Vanessa, a housewife and member of a communal council in Propatria, explained it:

Our constitution, approved by referendum, I think it is one of the first ones in the world which is made by the people and for the people, it indicates that this is a protagonic process ... participatory and protagonic. So we the Venezuelans have understood that participation and being a protagonist is part of each of us, I protagonize when I study and can bring this knowledge with me to my community, when I can change my way of being and be a different person. I am a protagonist when I change my family, because I am raising new men and women for society...

Protagonism within the Bolivarian space is thus conceptualized as a way of enacting citizenship through "a bundle of practices" (Lazar 2008:259) that cross-cut both the personal and the political as well as the individual and the collective. 


\section{The Missions}

Popular participation in the context of the Bolivarian process has gone through various stages. As we learned in Chap. 3, Venezuela has a rich history of autonomous grassroots movements that also played a crucial role in the Chávez era. But the Chávez government also fomented new forms of organizations that were situated, to various degrees, in the interface between the state and the grassroots through focusing on social welfare and political empowerment. The coup against Chávez in 2002 and the oil sabotage in $2002 / 2003$ proved to be watershed moment in this respect. After the sabotage was defeated in early 2003 , the economy was in ruins, poverty rates had risen drastically as a result of the strike and Chávez was dropping in the polls. Shortly thereafter, the so-called misiones sociales (social missions) were launched-a series of poverty alleviation and social welfare programs that would be financed by PDVSA and government funds (see D'Elia and Cabezas 2008; Hawkins et al. 2011). In many ways this marked a new era in Chávez's government. Both the government and its grassroots supporters had become radicalized following the coup and now viewed the way forward as moving toward two objectives: advancing the Bolivarian project, and forging a union against the sectors that had sought to remove the government.

In order to bypass the notoriously corrupt and inefficient bureaucratic state structures, the social missions were implemented with the direct collaboration of popular sector groups, PDVSA, local governments, military personnel, special administrators linked to the presidency, and a host of Cuban advisors and technicians. In 2003, Chávez and Fidel Castro struck a deal guaranteeing Cuba cheap oil in exchange for the support of Cuban doctors and advisors in setting up the missions in Venezuela (see Brouwer 2011 for a detailed account of this program). Thousands of Cuban doctors traveled to slums and remote countryside areas in Venezuela as part of what was called Misión Barrio Adentro: without doubt the most popular government social program. During phase 1 of the program, the Cuban doctors lived in private homes where they attended to patients and collaborated with local health groups in making home visits and in setting up outreach programs to bring preventive medicine and vaccines to local communities.

Later, the characteristic two-story octagonal health stations were built, with doctors living on the second floor, and patients' visits taking place in the first floor. Under phases 2 and 3 of Mission Barrio Adentro, clinics, 


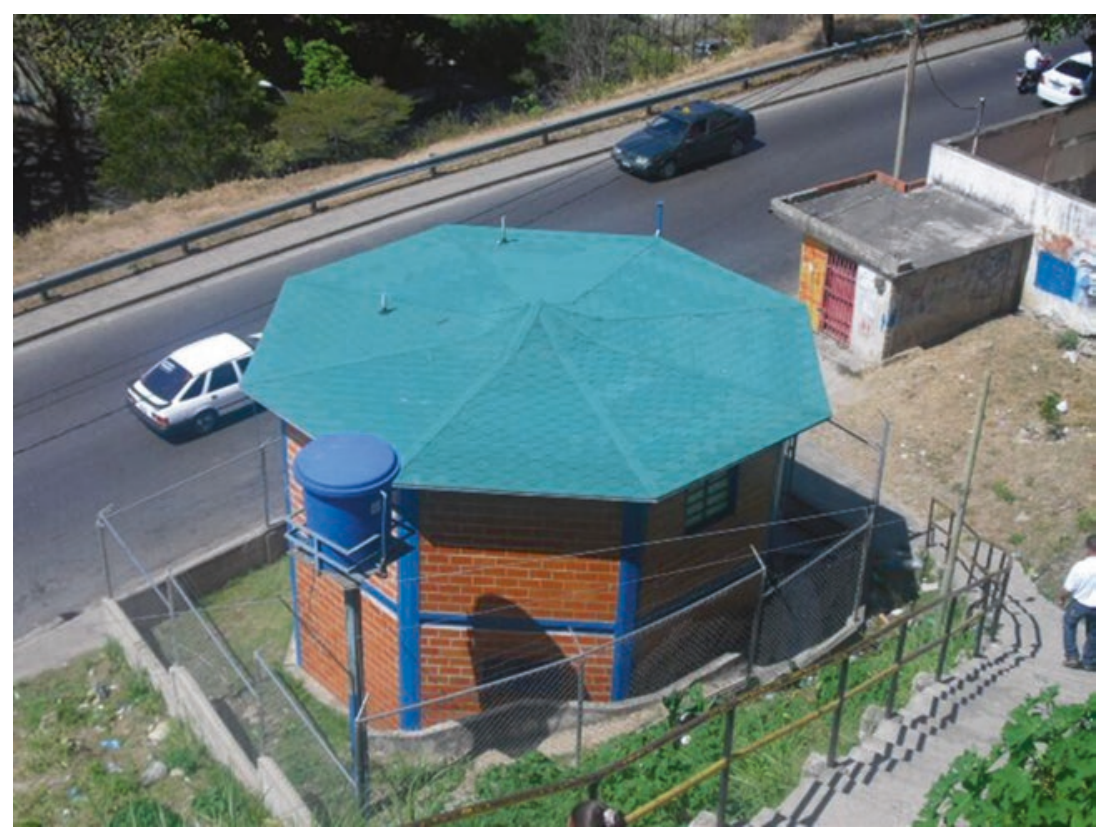

Photo 5.1 A typical module of Barrio Adentro in 23 de Enero. Photo by the author

rehabilitation centers and advanced medical hospitals were built. The health outreach also included dental services (Misión Sonrisa) as well as Misión Milagro, which treated people with eye diseases such as cataract. This was a widespread condition among the poor and elderly who could not afford even routine operations.

The government also set up, with the support of Cuban educators, what are known as the educational missions: Robinson 1 and 2, Ribas and Sucre. Robinson 1 was aimed at teaching illiterates basic reading, writing and math skills, while Robinson 2, Ribas and Sucre were aimed at primary and secondary education, and university-level education. Additionally, community programs for culture and sports were also implemented, as well as Misión Vuelvan Caras - a practical skills training program promoting the formation of co-operatives. Community programs for sports and culture were also organized, notably Misión Cultura. In 2005, Venezuela declared itself to have become a territory free of illiteracy. UNICEF described Misión Barrio Adentro as a "model of comprehensive primary 
health care with active community involvement" (Nichols and Morse 2010:211).

Another highly cherished mission was Misión Mercal, which put in place a government system for the distribution and sale of subsidized food. The political impetus for setting up such a system stemmed from the 2002 to 2003 strike, which showed how food supplies could be used as a political weapon. Small shops and bodegas were set up in rural areas and shantytowns, where basic goods were sold with discounts up to 40 percent. The program also included "soup kitchens" called Casas de Alimentación, staffed by local volunteers who served a full, healthy meal each day to the community's most vulnerable individuals-children, the elderly, the homeless, poor, pregnant women and others who were singled out as particularly vulnerable by the health census carried out by the local Barrio Adentro health committee (see Strønen 2006).

In February 2002, Chávez issued Presidential Decree 1666, which provided the initial legal framework for land titling in barrio settlements. ${ }^{2}$ Through local committees called Comites de Tierra Urbana (Urban Land Committees-CTU), consisting of 100 to 200 families, barrio residents who could prove that they had built their homes themselves could obtain titles for the land they occupied. In some cases, this was state land, and ownership was directly transferred. In other cases, it was private land and the state had to buy it first. This work was co-ordinated by the Oficina Técnica Nacional de la Regulación de Tenencia de Tierra Urbana (National Technical Office for the Regulation of Urban Land Tenure-OTN), an institution that was part of the vice-presidency (García-Guadilla 2007:48). According to government reports, by 2006, there were 6000 CTUs organized across the country, covering about one million families (García-Guadilla 2007:48). Given that about 90 percent of the Venezuelan population was living in urban areas, and around half of it in informal settlements, this was a crucial issue. At the same time, local communities organized themselves in Mesas Tecnicas (technical roundtables), mapping deficiencies and improving local infrastructure related to water, electricity and gas distribution, in co-ordination with relevant state bodies such as Hidrocapital (water utility) and Electricidad de Caracas (electricity). Other forms of organization were the Centros de Participación para la Transformación del Habitat or CPTH (Participation Centers for the Transformation of the Habitat)comprising several CTUs and addressing issues under more than one CTU's responsibility. 


\section{Steep Learning Curve}

These numerous experiences constituted a steep learning curve within popular sector communities. New local leadership figures emerged, and social interaction and cohesion in the barrios increased (see Strønen 2006, 2012). Moreover, it also increasingly socialized the popular sectors into the laws, language and procedures of the state, and created networks between the popular sectors and political figures. Local grassroots networks and electoral committees, organized around election time in support of the government, also added to the proximity between the government and popular sector activists. This became an important reference for the next phase of state-supported popular organization: the communal councils.

The communal councils were institutionalized in 2006 through the Organic Law for the Communal Councils. ${ }^{3}$ The law was revised, also through an extensive popular consultation, and reapproved by the National Assembly in November of 2009. Communal councils are local neighborhood groups, organized around 200 to 400 families in urban areas (significantly less in rural and indigenous areas). They are granted the legal right to plan and implement local social and socio-economic projects as well as projects related to community housing and infrastructure. These projects are funded by the government through various agencies.

A communal council is composed by three administrative committees $^{4}$ and various thematic work committees. The citizen assembly is the maxima instancia de autoridad (highest authority) in the communal councils and composed by all members of the community. All members of the community above the age of 15 have the right to vote, and the elected members of the other committees have to abide by the citizen assembly's decisions. Thus, the community as a whole does not cede power to the elected members of the community councils. In order to highlight this aspect, elected members are not called representatives, but voceros and voceras (spokespeople). The members of the communal council are elected for an electoral cycle of two years. There is also a permanent electoral committee responsible for elections and revocation of mandates.

It is up to the community to decide exactly which working committees they want to form; those suggested by the law are health, education, 


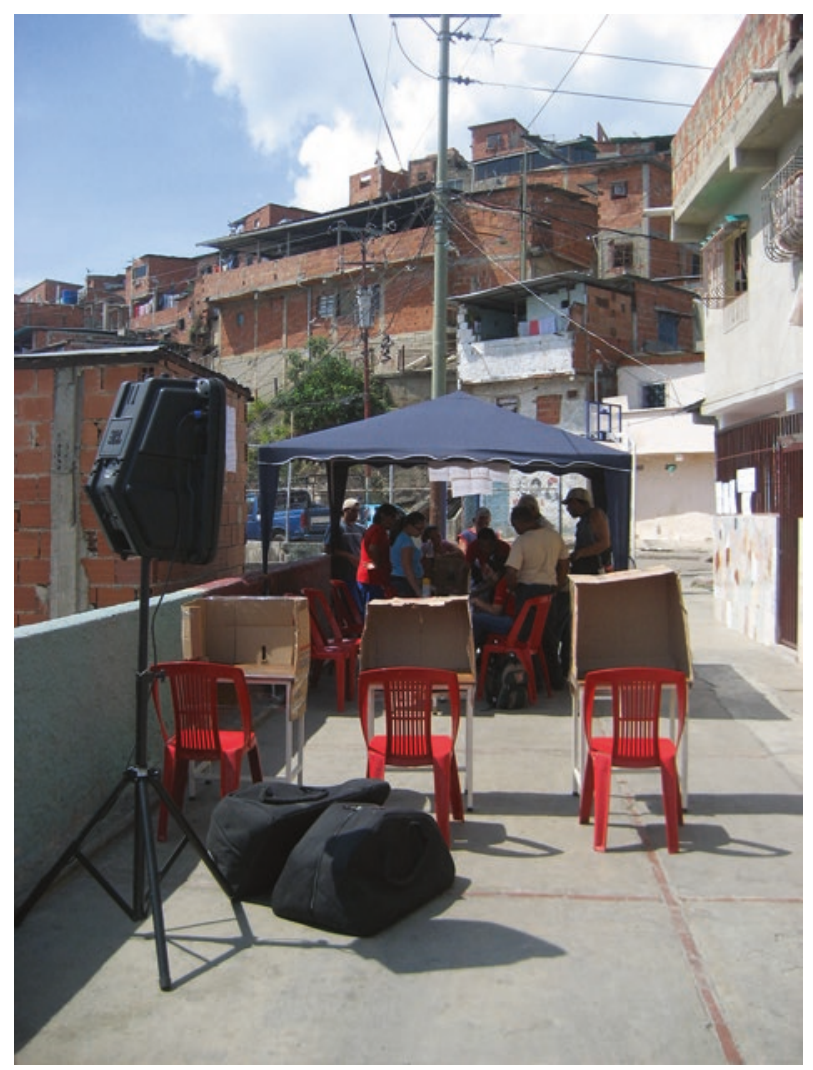

Photo 5.2 Elections in a communal council in 23 de Enero. Photo by the author

housing and habitat, communal economy, security and integrated defense, communitarian alternative media, recreation and sports, alimentation and defense of the consumer, water, energy and gas, social protection of children and adolescents, physical disabilities, education, culture and citizen formation, and finally family and gender equality. The law spells out in detail the electoral procedures, organizational steps and legal requirements that a community has to go through in order to formally constitute itself as a communal council. 


\section{Communal Power}

The communal councils were considered as part of the "Fifth Motor of the Revolution"-communal power-defined as one of the five paths toward the construction of Socialism for the twenty-first century. The contours of the five motors of the revolution were outlined in the Simón Bolívar National Project 2007-2013 (República Bolivariana de Venezuela 2007). ${ }^{5}$ The overarching idea for the five motors was to create political mechanisms superseding and supplanting existing political, legal and territorial structures:

We have to march towards the conformation of a communal state, and the old bourgeois state that is still alive, that is alive and kicking, we have to progressively dismantle it while we go on constructing the communal state, the socialist state, the Bolivarian state. (Hugo Chávez 2007, cited in Aguiar 2007, author's translation from Spanish)

The gradual process of creating the framework for the communal councils in the 2006 law can be read as a radicalization on the government's part of the expansion of popular power as well as a pragmatic assimilation of past experiences. In 2002, the government had passed the Law for Local Councils for Public Planning (Consejos Locales de Planificación Publica or CLPP). The law promoted popular participation in the planning, allocation and execution of public local budgets at the municipality and parish level. In 2005, the government passed the Organic Law for Municipal Public Power (Ley Orgánica del Poder Público Municipal). None of these reforms proved successful in promoting popular participation and mobilization at the grassroots level (Wilpert 2011). People recall that participatory attempts were co-opted or stalled by political figures and brokers at the municipal- and parish level, at the same time as people were getting more experienced in organizing and identifying needs in their immediate communities. This required a new political and legal mechanism that channeled resources directly into what people themselves considered a socio-spatial organizational forum.

\section{The Communal Councils}

Thus, the 2006 Law of the Communal Councils grew out of a gradual process toward searching for organizational and legal frameworks for public participation at the community level. The 1999 constitution has a 
range of references to popular participation, though it does not explicitly mention poder communal (communal power) in its pages (García-Guadilla 2008:8). ${ }^{6}$ However, the constitution explicitly states that citizens have the right to participate in a "direct, semi-direct and indirect manner," including in the "formation, execution and control of public management (gestión pública)" (López Maya 2011:224-225).

The bulk of the resources destined to the communal councils comes from the Intergovernmental Fund for Decentralization (Fondo Intergubernmental para la Decentralización or FIDES) and the Law for Special Economic Allocations derived from Mines and Hydrocarbons (Ley de Asignaciones Económicas Especiales derivadas de Minas e Hidrocarburos or LAEE). Additionally, the communal councils can seek funding from a range of other public bodies, such as parishes, municipalities, ministries and state banks. They can also receive gifts, donations or generate their own income. In 2010, the communal councils received 2.3 billion bolivares for executing community projects. As a term of comparison, municipalities received 2.1 billion for performing their functions (Jaua 2010, cited in Álvarez and GarcíaGuadilla 2011).

Communal councils initially registered with and gained legal status through the Local Presidential Commission for Popular Power (Comisión Local Presidencial del Poder Popular), which was directly appointed by the president. This arrangement received much criticism (López Maya 2011) because it linked the communal councils and the state directly to the executive. Later, this role was passed on to the Ministry of Popular Power for the Commune and Social Protection (Ministerio del Poder Popular para la Comuna y Protección Social). ${ }^{7}$ Fundacomunal, a state institution with sub-offices across the country, is responsible for supervising the organization of the elections, supporting electoral processes and developing projects, as well as distributing resources to the communal councils.

In 2009, the government also introduced the communes"confederations" of several communal councils covering a larger geographical area and with broader legal, financial and administrative rights and responsibilities. In December 2010, the Ley Orgánica de las Comunas (Organic Law for the Communes) was passed by the National Assembly. The communes were presented as the cornerstone of the project to gradually institutionalize popular participation as a new socio-politicaleconomic model. Gradually, they multiplied in numbers and became more 
organizationally consolidated and integrated across the national territory (Ciccariello-Maher 2016), though, just as the communal councils, they are also highly heterogeneous in scope, form and function (see ibid. for details).

\section{SPATIAL AND Social LANDSCAPES}

Ever since I first arrived to Venezuela in 2005 and started to get to know the barrios, it always fascinated me how people seemed to carve out an intimate relationship with their immediate surroundings. Also, I gradually realized how the unfolding of community activism was essentially shaped by spatial and social formations constitutive of popular sector communities. Seen from a distance, the sprawling barrio hillsides look like an impenetrable and homogenous mass. However, from the inside they appear as "a finely differentiated congeries of "micro-locales" (Auyero 2001:93). The barrio contains numerous, sometimes clearly delineated and sometimes partially overlapping, social micro-worlds. Territorialities-both spatially and socially-are inscribed through local histories, limitations in topography and geography, the design of streets, stairways, passages, squares and recreational areas. Each area or zone is imbued with a social identity, forged by the mutual identification between the people living there and their relation to that space. As one man said at a public meeting, describing communal councils: "Territory is not only geographical; it is the territory that we feel."

Barrio sociality and everyday life is radically different from middle- and upper-class lives. Barrios are crowded and over-populated, but also social and informal. Often large chunks of the day are spent in the street, and private space is a luxury, both inside and outside the house. Other people's lives are thrown at you, whether you want it or not. Music, babies screaming and family fights blast out through open windows and doors. Barrio social interaction and street codes are characterized by informality: the ability to crack jokes, to tell stories, to know the fine line between insult and banter, to manage the local slang and to have a generally playful way of speaking, often with a sarcastic undertone. The social code of the barrio is very much characterized by knowing how to manage one's "front stage personality" (Goffman 1956). Stories and information, be it gossip or news, are shared in an almost competitive manner: it is important to show that one "knows," that one is well informed and well connected.

People often have a strong sense of belonging to their barrio and sector. Each barrio and each sector has its own characteristics reflecting 
the history of the barrio and the people who inhabit it. The feeling of belonging is also connected to the sense of personal security and insecurity. Without the option of hiding behind high gates, security guards and cars with tinted windows, personal security is governed through knowing where, when and how to move in the street, and having personal connections to people. Social territorialism is inscribed in the landscape in a number of ways: through "knowing" one's space and place, through a barrio's or a sector's history, through neighborhood associations, through local control exercised by criminal gangs or others popular groups and networks, through sharing certain forms of infrastructure, through natural demarcations such as streets, buildings, hills and so on.

To varying degrees, barrio communities are characterized by tight social networks-for better or worse. The Spanish saying "pueblo chico, infierno grande" [small village, big hell], captures the barrio reality with the constant gossip, conflicts and quarrels. But day-to-day living also allows for developing relationships of reciprocal help and solidarity. Throughout the years, community infrastructures have been developed through collective work. Often-on weekends and holidays in particular-people bring their chairs out in the street or talk with their neighbors in the street corner. Sometimes neighbors look after each other's children, or borrow gas tanks, food or other items. During the 2002-2003 oil strike, when many popular sector neighborhoods experienced food scarcity, many communities started cooking collectively, everyone bringing what they had at home.

\section{Patterns And Processes}

Thus, communities are dense social landscapes shaped over time, and its inhabitants may have friends or foes that go a long way back. On a deeper level, the precariousness of social trust (Ystanes 2011) may often make it difficult for people to forge alliances with the people they do not know, or those that are perceived as different from "my" social micro-world (from the other side of the street, from the buildings "over there," from the barrio "up there"). The difficulties of forging social bonds that can facilitate community cohesion are also important factors for fueling disputes and multiple claims over what the community is and who can rightfully represent it.

At the same time, new strategic alliances and friendships were continuously formed or dissolved within a community. Political and ideological differences, intensified in the polarized political climate, shaped alliances, but did not determine them. People often had radically different 
motivations for taking part in community activism. Whereas some were primarily motivated by hopes of material gains, or by individual aspirations, others viewed activism as a larger political and ideological struggle that should be guided by altruism and work for the common good. As Gledhill notes:

Social action is structured by the pursuit of "interests" by human agents, although the content of those interests is always determined culturally, and may not be "material" or "economic" in the narrow sense. (Gledhill 1994:134)

These diverging perceptions of what community politics were and should be, and the different motivations for participation, were important factors in sharpening the conflictive edges of community politics.

At the same time, local contentious issues were also a part of a larger picture of social and political processes of change. People had differentiated access to wider networks outside the community, to politicians, bureaucrats and public officials, shaping the unfolding of events of internal struggles. Laws, political priorities and institutional processes had direct impact on the life in the communities. Political conjunctures and events could cause community mobilization to stop, to change its focus or to come to a momentary halt.

Thus, community politics are shaped by the intimate and the social, by the intersection of macro-politics coming from above and micro-politics coming from below reshaping local, social and political relations. It is the fluidity of these processes, and the underlying social patterns that sustain and shape them that we need to understand if we want to get a grasp of the real-life dynamics of the unfolding of popular politics during the Chávez era. As Nuijten cites Fredrik Barth on stating: "I am in no way arguing that formal organisation is irrelevant to what is happening-only that formal organization is not what is happening" (Nuijten 2003:157).

\section{The Particularities of 23 de Enero}

The community where the case study that we now will turn to is taking place, 23 de Enero, is quite distinctive from other communities in Caracas (Ciccariello-Maher 2013 for detailed accounts of its history; see also Velasco 2015). As we have previously learned, this parish is histori- 
cally famous for being a hotbed for leftist radicalism. In particular, it is famed for the so-called colectivos (literally, "a collective") whose presence gives the parish a set of particular social, political and spatial dynamics. It is important to note that grassroots organizations calling themselves colectivos are found in a range of popular sector neighborhoods, dedicated to various social, political and cultural activities. However, the particularity of the colectivos in 23 de Enero rests not only in their fame, visibility and organizational strength, but also in their spatial control. Within 23 de Enero, different colectivos are claiming different territories, and the police has not had a formal headquarter in the community for decades. (During Puntifijismo, as we learned in Chap. 4, the local police headquarters was notorious for being a center of police violence.)

The colectivos' presence is highly visible in the community. Their names and slogans appear on murales, wall paintings, often of impressive artistic quality, decorate walls and fences all over 23 de Enero. The murales also feature political slogans, images of deceased revolutionary martyrs or international leftist icons, and political symbols. The most famous colectivos are arguably La Coordinadora Alexis Vive, La Coordinadora Cultural Simón Bolívar, Los Tupamaros and La Piedrita, but there are numerous others with less power and public visibility.

As a rule of thumb, the more powerful and well-established a colectivo's claim over an area is, the safer it is, as "competing claims" for territorial control emerging from criminal gangs and drug vendors are not allowed to escalate. More generally, the 23 de Enero parish is considered one of the safest barrios-if not the safest-in Caracas. Personally, it was within the confines of the territorial areas of the strongest colectivos that I felt the most at ease in Caracas. That being said, their territorial control also comes with a price, and there have at times been a lot of blood spilled in disputes with "enemies" such as drug vendors and delinquents, as well as in rivalries with other colectivos in the area. It is no secret that they are armed, and some of them also cultivate a public image in which arms are very present. This is also part of the reason why the colectivos have a very ambivalent status in the community.

The colectivos are also extensively engaged in social and cultural activities, both on their own accounts and collaborating with the communal councils and other social groups. However, as we will see in the following case study, many residents are wary of their claims to local power, in particular as the communal councils surged as an additional source of formal local authority. 


\section{UNDER SIEGE}

Radical political organization in 23 de Enero dates back to the Pérez Jiménez era and his fall in 1959. The colectivos' later evolution into relatively organized and armed groups came as a response to excessive state violence in the Puntofijo era (see Ciccariello-Maher 2013). In the beginning of the 1980s, 23 de Enero started overflowing with drugs. Several of my interlocutors alleged that this was planned by the government as a means to de-stabilize popular organization in the community. Similar statements have been documented elsewhere (Martinez et al. 2010:274; Ciccariello-Maher 2013:77). To what extent it was a government strategy, is difficult to prove, but what is certain is that lower-level police officers were heavily involved in drug trafficking, cutting deals with, and supplying, local criminals and drug dealers. In any case, the community found itself under siege by both the police and criminal networks. It was the need to respond to these threats that led to the creation of colectivos as distinct, territorially rooted, social organizations. Armed and masked, they would give local delinquents an ultimatum: "Disappear or we will eradicate you." Simultaneously, the police (the Policia Metropolitana in particular who played a crucial part in the 2002 coup and was later dissolved by the Chávez government), famous for its corrupt and violent practices, was a declared enemy.

\section{Ambivalent ReLATIONSHiP}

Among the opposition, as well as in national and international media accounts critical of the Chávez government, the colectivos have frequently been portrayed as armed, violent and dangerous vigilante groups, some also referring to them as the government's paramilitary branch. It is beyond the scope of this book to discuss the "true" nature and correct label of these groups, but many of these accounts have often drawn on hearsay and the invocation of politically charged imageries of the savage mobs and hordes (Duno-Gottberg 2009) discussed in Chap. 3, rather than documented analysis of their actual form and function. However, the colectivos have on various occasions resorted to violent tactics, something which also brought them on collision course with the Chávez government. For example, in February of 2009, a group from the colectivo La Piedrita attacked the headquarters of the opposition TV station Globovision at night with teargas and pamphlets. Their motivation was the perception 
that Globovision had been attempting to incite a coup. The attack provoked a strong response from Chávez who publicly stated that this behavior was no better than the behavior of the far right and that the leader of the group, Valentino Santana, should be arrested.

As Ciccariello-Maher (2013) has shown, the relationship between the government, the colectivos and the Bolivarian process cannot be understood without taking into account their popular genealogy and ideological orientation. For the colectivos, and many popular sector activists more generally, the Bolivarian process in Venezuela is perceived of as the fruit of a long popular struggle. From this perspective, Chávez was by the colectivos perceived of as a catalyst for a broader political struggle, as well as their "maximum leader" (Ciccariello-Maher 2013:5, 84-85). However, they were above all profoundly identified with la lucha popular (the popular struggle)—a struggle that goes far beyond the figure of Chávez.

There is also another important dimension to add, namely that 23 de Enero in general and the colectivos in particular have always been a thorn in the side for the Venezuelan right. Both the colectivos and the so-called Bolivarian Circles were singled out for persecution during the 2002 coup. Allegedly, a list over political activists and community leaders that would be hunted down had been elaborated by the coup mongers, and political persecution of Chavista leadership figures was already well under way when the coup was aborted. As was said at a community meeting in 23 de Enero that I attended: "If Chávez falls, the first place they are going to crush is 23 de Enero." For that reason, the colectivos do see themselves as the armed vanguard for the Bolivarian process should the Venezuelan right try to take over power again with illegitimate means. But so do many other people, whatever name they give themselves or their networks. The colectivos can therefore not be seen in isolation, but as part of the broad heterogenous landscape of popular sector organization and in the context of a long history of struggle from below-including the coup in 2002.

\section{From the General to the Specific}

James Scott has stated that "Any carefully detailed empirical case is always far richer than the generalizations that can be extracted from it" (Nuijten 2003:21). Taking cue from his insight, the rest of the chapter will explore in detail a long process of community mobilization in 23 de Enero that involved colectivos, communal councils and other local community members and activists. The mobilization's aim was to force the government to 
complete the construction of a local hospital, a Centro de Diagnostico Integral (CDI), which is part of the Barrio Adentro mission. The hospital had been abandoned two years prior, just before it was finished, and had been since taken over by rats and drug addicts. In 2009, some people in the community decided to mobilize in order to pressure the government to complete it. Both adjacent colectivos and communal councils got involved, generating a long-term field of interaction (Nuijten 2003) in the form of work groups, activities and meetings between the community and a host of state representatives.

These forms of negotiation revealed how claims of legitimacy, popular sovereignty and power played out vis-à-vis the state. At the same time, an intense mobilization over the politics of local socio-political space was generated: Who would "control" the mobilization? Which interests were at stake? Who had connections to people in high-ranking positions? Who could successfully claim to represent the community? How would "the community" be used as a strategic concept for negotiating internal differences? In short, the case study constitutes the ideal "condensed case" allowing me to capture both the specificities of 23 de Enero and the broader processes characterizing community-led mobilization and the interaction between community and state.

\section{The Story About the Centro de Diagnostico InTegral (CDI)}

The first time I heard about the CDI was at a community meeting in the Christo Rey zone in the spring of 2009. I was invited to attend the meeting by Oscar, a man in his early 50 s who was a member of an "old boys" colectivo in 23 de Enero. They were primarily organizing cultural, social and political activities and differed in that sense from the more publicly visible colectivos which were also concerned with cultivating their image and had a more militant style. However, both Oscar and the other members of the colectivo had lived in 23 de Enero pretty much all their lives and knew a lot of people in the parish.

At the time, I had just arrived in 23 de Enero and had been introduced to Oscar by a friend of a friend. He was a good-tempered man with an internationalist outlook, and was happy to bring me into the parish. The meeting that he brought me to that evening, held in the local primary school, was about the communal councils, and representatives from several state institutions were present. Toward the end of the meeting Oscar 
asked if he could address the crowd with a pressing issue. He spoke passionately about the abandoned CDI, and stressed that the completion of the project would benefit the whole community. The first opportunity to get involved would present itself on the same night of the meeting, he said, in a community assembly by the abandoned building. Oscar and I left by foot for the assembly shortly thereafter. When we arrived a group of 40 to 50 people were gathered outside the locked gate leading into the construction site. No one had the key to the gates, or was able to locate someone who could have provided them. As it was getting late, the meeting was dismissed, and a new one was scheduled for the following weekend.

\section{A Tale of a Stranded Project}

The initials "CDI" stand for Centro de Diagnostic Integral (Center for Integrated Diagnosis). CDIs are part of the Barrio Adentro health system, which was created in 2003 by the Chávez government. The system covered both Barrio Adentro 1, with its octagonal primary health care station, and Barrio Adentro 2, which houses both hospitals (complete with emergency and surgical units) and rehabilitation centers. As previously stated, the Barrio Adentro health system relied on human capital and material supplies from Cuba, based on the oil-for-doctors exchange between Venezuela and Cuba, which was initiated in 2003.

When I started my fieldwork in 23 de Enero in the early spring of 2009, there was only one CDI, located in the F-zone. In addition, there was a rehabilitation center (CDR) in front of the Christo Rey barrio. Behind the rehabilitation center, located between a football and a basketball field, stood what was left of the abandoned CDI building. The only other hospital in the immediate vicinity was Clinica Popular de Catia, located two blocks from Plaza Catia. However, it was a private hospital, which meant that patients either needed health insurance or had to pay for their treatment directly.

Out of all the missiones (social programs) that the Chávez government had launched, the Barrio Adentro system was probably what people appreciated the most. The public healthcare system before Chávez was highly inadequate. Privatization and reduced public spending had relegated the poor sectors of the population to an overcrowded and decaying public health system. Many people died from the lack of access to health care. As there weren't any health stations in the barrios, people had to go to the city center to get treated: an expensive and difficult journey for someone 
living high up on a barrio hillside and perhaps couldn't even afford a bus ticket. If someone needed emergency treatment, they had no guarantee of reaching a hospital or being attended to in time. People told me of family members who had died or nearly died in the waiting room because of inadequate and irreverent treatment. Hospital supplies were often nonexistent or not accessible; one had to have his or her own supplies or buy them from hospital personnel who had stolen them in the first place.

In Venezuela, private health insurances are paid by employers, which mean that the majority of citizens, making a living through the informal or semi-formal sector, were effectively left out of the private health system known as clinicas privadas (private clinics). After Chávez's arrival to power, a larger share of the lower-sector population got health insurance because the possibility to access public sector jobs increased-or because people had a relative that was insured. (It is sometimes possible to extend coverage to the family members of an insured individual.) Yet, many people still depended on the public health system. Having a private health insurance is not necessarily a guarantee of receiving sufficient or adequate treatment. Health insurance plans have coverage limits, and if the insured exhausts that limit, for example, in the case of chronic or longterm illnesses, they are left with no option but to pay out of pocket or to resort to the public system. An important and highly cherished part of the Barrio Adentro health system was thus the Cuba-Venezuelan agreement, whereby people were sent to Cuba for free treatment of complicated, longterm or chronic illnesses. ${ }^{8}$ In terms of primary care, the Barrio Adentro 1 installations have been vital in attending patients in the community that would not have been otherwise able to reach, or afford to go to, a private primary care doctor. The Barrio Adentro 1 system was fundamental in its implementation of vaccinations programs, maternal health outreach, old age and disability outreach, as well as in dispensing medicines that would otherwise be very expensive in private pharmacies. In short, in spite of its shortcomings, the Barrio Adentro system was widely considered the most cherished logro de la revolución (achievement of the revolution).

\section{The Building of The CDI}

CDIs respond to the Ministry of Popular Power for Health (Ministerio del Poder Popular para la Salud), supported by Cuban health professionals working under the vice-ministry (located opposite the presidential palace Miraflores). 
The construction of the CDI in 23 de Enero had started in 2005, through the co-operation of various health committees with the different Barrio Adentro 1 health stations. At the time, the Chávez government was in the process of starting up the Barrio Adentro II phase. The CDIs were the cornerstones of expansion. When this was announced, the local health committees seized the opportunity and made contacts with the Ministry of Popular Power for Health in order to locate a CDI in their area. After long discussions among the co-ordinators of the various health committees in the parish, and in spite of disagreement within the community, it was decided that the only suitable location for the construction of a hospital would be the field where it stands today. It was also decided that the hospital would take over part of the adjacent football and basketball fields.

The building was to be financed by the Instituto Nacional de la Vivienda or INAVI (the National Institute for Housing). The ente ejecutor (building contractor) was Fundación Caracas, or Fundacaracas, which is the property development branch of the Libertador Municipality. Construction work was contracted out to a private company.

The construction process got off to a quick start. However, as Felipe, one of the key community activists involved in the process, later told me, various neighborhood groups soon noticed that things weren't going smoothly.

When the problems started the neighbors over there in the Sierra Maestra sector alerted us, the social groups in the area, that there were problems with the construction of the CDI ... and well, we go over there, we present ourselves, we identify ourselves as the contraloría social (social comptrollership), we talked to the company, we talked to the on-site responsible for the work, and we alerted him to some of the observations that we were making, because there were cracks in the walls, in the roof, the waterproof cover on the floors was deteriorated.

We could see that the job was not done the way it should be, and we started to fight with the head of the company ... we also started to fight with the inspector chief of the work, who we made responsible for the level of deterioration that was taking place. Why? Because he had the obligation to make his observations and report to Fundacaracas so that the work was paralyzed or they sent another company to finish it. So that they could end the contract and we could start up again with another company that was doing the work well ... we had a lot of problems because parts of the population that were living nearby, who had some interests in the CDI, started to attack us. 
Among other serious problems with the construction, I was told at a later meeting when we entered into the building, was the joint compound between the ceramic tiles on the walls, which had a rough, untreated surface. This was illegal for a medical facility, as germs and bacteria could stick to the porous joint compound mass and make it impossible to adequately sterilize an operating room. Felipe told me that, when they later got the project up and running again, they discovered there never was a proper project plan in place. However, at the time, they were simply trying to identify who was responsible and attempting to fully understand what was happening.

We made a number of denouncements, we have copies of a quantity of communication that was sent to people, to Fundacaracas, to INAVI, to many organisms where we are alerting them that the health center is constructed in an erroneous manner ... additionally, it was only two workers for a twostory building, that was insufficient, it would be impossible to inaugurate it in 2007. So we were asking ourselves how is it possible that a center that was supposed to be opened in 2007 had only two people working there.

And well, in the end, within all this pugnacity, there were a lot of problems with those that we think had particular and peculiar interests in this centre. In this case it was the consejal (parish council woman), who was always benefiting from (montada) the health committees, and there was another woman, you met her, who is the señora Yurelia, every time we went there she was confronting us.

On one occasion, we asked her to identify herself, to clarify if o era empresa o era communidad (she was company or community) because she couldn't be both things at the same time ... every time we went to ask the company to show us the accounts, she was confronting us, saying that they were doing a good job, that they were constructing it well, that they had been there that day and just left. We never understood what the interests of that lady were, we really don't understand it still ... to us the important thing is the benefit of the community....

In the end, Fundacaracas and the company made a number of promises, that they were going to finish at the stipulated time. The building was almost 90 percent completed, what was missing were some details and that people from the Cuban mission came and installed the equipment in order to make the center operational. So we retired and thought that we had completed the mission, this was in the beginning of 2008. Our surprise now is that the center is abandoned, we didn't know...

The official explanation, now that the community had taken over the project, was that the project had been abandoned because the construc- 
tion company had run out of money and had to rescind the contract. From Felipe's account, it was clear that there were a lot of "particular interests" surrounding the project, within the community, within the local political office, within Fundacomunal and the construction company. It is quite common in Venezuela for construction projects to stop because of budget limitations, which in reality means that all different interested parties have taken their cut of funds. In this case, the construction company just packed up and left once the community activists were convinced the project would be completed. When the company left the building site, construction was approximately 90 percent completed. But once they left, both the site and the building turned into a dump: stripped of everything of value, its windows smashed, teenagers looking for a place to drink alcohol and do drugs. No one had approached that building until now.

\section{Finding Common Ground with the State}

When I showed up at the following meeting, which took place on a Saturday afternoon, a dozen people were outside the building. Some people from the community had already tidied the area, but rubbish and construction material were still scattered around the site. The CDI was a large, rectangular two-story building of a yellow-orange color, clearly in a state of abandonment. Just behind the building, behind its fence, was a large barrio community. There was a baseball field next to the building, and on the other side a large football field in dire need of maintenance. The octagonal Barrio Adentro health building and the Sala de Rehabilitación Integral or SRI (Center for Integrated Rehabilitation) were located in front of it, next to the street. On the other side of the road, and north of the football field, were two additional large barrio communities.

As I had just started my fieldwork in 23 de Enero, I didn't have a clear idea of "who is who" in the community. However, it was evident that several of those present at the site that day were from the famous colectivos in 23 de Enero. Their militant-like posture and green T-shirts made those belonging to the colectivo La Piedrita particularly easily discernible. As I would soon learn, the presence of the colectivos generated a lot of uneasiness among many community members.

Oscar and Felipe were running around slightly stressed, trying to set up the sound system and microphone that they had brought with them. More and more people were coming, standing in small groups talking, 
and eventually Oscar grabbed the microphone and welcomed everyone. He explained that it had come to their attention, a couple of weeks earlier, that the center was abandoned and dysfunctional, and said that they had contacted other compañeros in order to get the construction process started again. The colectivos had tomado los espacios (taken over the site) two weeks earlier. They had convoked the meeting with the purpose of rescuing this site and converting the abandoned building into a functioning hospital attending the whole of Caracas, he explained. "This is a part of paying the social debt to the poor." Knowing very well that not everyone in the community was happy about the presence of the colectivos, he nipped the criticism in the bud by saying that: "Many have asked themselves what the compañeros from the colectivos are doing there." Some people were nodding. "But," he added rhetorically, "we are all compañeros, and we have all known these sites since we were children, though then we were running across these fields with the police behind us."

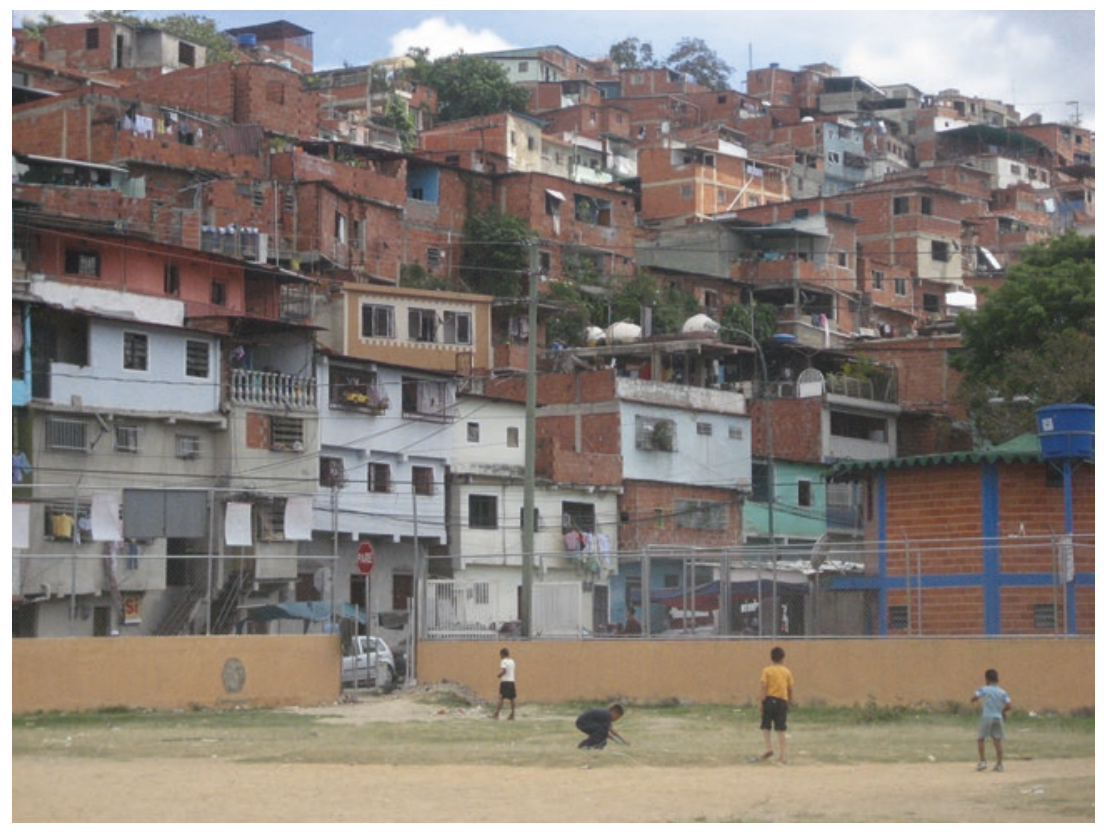

Photo 5.3 A deteriorated football field, a Barrio Adentro module and informal housing constructions in 23 de Enero. Photo by the author 
Oscar had a fascinating personality, never afraid to speak his mind, but always doing it in such a refined manner that he seldom came off as confrontational (even though he clearly was). Like most Venezuelans, he was a gifted speaker. He rhetorically went on to ask who had given the permits to privatize the fields that "some people" were exploiting for their own benefit. By "some people" he meant Señora Yurelia, the woman who had control over the baseball field, and who had come running to the site every time they came to talk to the construction company. I soon learned that she was a key person in the matter of the CDI. She seemed to be a local community "patron," with considerable power for controlling the baseball field. She made money charging baseball teams for using the site for practices and events, as well as selling beer. Additionally, she allegedly had two grown-up sons who could be quite intimidating.

The next speaker was Felipe, who summed up the community's demands: that the project be completed, that the hospital start functioning, that an investigation be launched and that those responsible be prosecuted for corruption "the same way Manuel Rosales should be." With a friendly gesture Felipe waved one of the "officially" invited representatives over-a man from the technical division of Fundacaracas. He was a slender man in his forties, speaking with a soft voice. He made no definite promises, but indicated that Fundacaracas might be able to begin the rehabilitation of the site, while they waited for the new fideicomiso (project commission) to be constituted, led by the Ministry of Popular Power for Health.

The problem was not only the CDI itself, but also the adjacent baseball and football fields. The football field had been used as a parking lot during construction. The weight of the parked trucks had damaged the drainage system beneath the field, and the area was overgrown with weed and grass. Repair and maintenance of the football and baseball fields were part of another project that had also been abandoned. The original budget for repairing the two fields had been modified twice, and the company in charge of the repairs had left before the work was completed. The repairs of the baseball field were about 90 percent complete, while the football field was in worse conditions and only about 70 percent of it had been repaired. The repair company was being fined daily for not completing the work, the public official from Fundacaracas informed. His proposal was that they sit down together (Fundacaracas, the repair company and the community) and form a mesa technica (technical working group) to 
figure out what could be achieved with the remaining project budget. It later transpired that the company had left the project because it had not been paid in time. A change in administrative procedures, involving the merging of two public offices, had caused payments to stop not only for this project but also for other similar projects in Caracas.

The floor was then taken by a representative from the vice-presidency, a chubby man in his late 30 s. His tense body language and uneasy way of speaking suggested that he was not used to being in a barrio or in a community meeting of this kind. After the customary greetings, and after congratulating the community for gathering, he said that the vice-presidency had first been notified about the unfortunate situation with the CDI on Tuesday that week. Once alerted, they had immediately contacted the necessary institutions, ${ }^{10}$ summoning people from the Ministry of Popular Power for Health, Fundacaracas and people from Barrio Adentro. He didn't understand why representatives from the health ministry were not present that day, but hoped

...that the outcome from today is that you elaborate your proposals, everything that you deem necessary, all the necessary complaints, and that a report is elaborated and handed to the minister in charge of the president's office and I will see if it is possible that the report can reach the president ... I cannot promise anything, this is not in my hands, but this is what will be done with today's events.

He concluded his speech by saying that he hoped Fundacaracas would resolve the matter as soon as possible because he was well aware of the importance of the CDI for the community.

The community applauded. Oscar then took the floor again, announcing that it was time for comments and questions from the community. He kindly asked that each speaker limit any comments to two minutes to keep the meeting from going on too long. For the next hour, a number of people took the microphone, some from the colectivos and others from the communal councils.

A man from a nearby communal council expressed his concerns about the safety of the site, and proposed that they arrange a 24-hour surveillance of the area. He was worried about the project being sabotaged, adding that "there are people who do not agree with this, they have personal interests, they have friends that have interests, economic interests, and their families have interests, so this is a problem that affects all of us." $\mathrm{He}$ also urged that the community needed to participate in the supervision and contraloría social of the project once it was up and running again. 
The lack of supervision was what ended the project in the first place, he stated, and it was their responsibility to safeguard it since they knew better than anyone what the problems in the community were.

An elderly woman from another communal council was also asked to speak. She was fumbling at first, but once she got started, she delivered a quite passionate speech, demanding to know the name of the company involved in the project and where it was: "Aha, the CDI was started, what was done, where is the money, it is necessary to look for them, to investigate, who are these people who were given money to do this work and then left it?" she said, visibly upset.

I hadn't noticed, I was sure that this CDI was working, I swore that this CDI was working, how is it possible that the CDI is in such conditions? So much money that the president hands over in order to get things done ... one thing is that it is really necessary, it is for health, it is for us, the community and those who are not from the community as well, because they can come from other parts of Caracas, from Antimano, from Carapita, from Los Frailes, from wherever they come they will be attended to ... we are the ones benefiting from this and how is it possible?

We have to find them, we have to make sure that this is constructed immediately, because that is why the president ... I hear the president talking all the time, I am a true revolutionary, in my heart, if I get nothing from the president I don't care, if they give something to me, fine, and if I don't get anything, fine ... I am 60 years old but I have a lot of grandchildren who are attending school and I have children who are studying, so I want this benefit for them and for those who will come ... so ... we have to fight, as communal councils we have to work on this, it is excellent what is being done here today, and the enterprise has to show up, those who started up all this has to show up, to show their face, to come and say, "look, it was because of this, there wasn't sufficient money, we could not do it, for this reason."

The woman ended her outburst by saying: "I wish that things were done as the president says, but that's difficult, we don't ... I don't know what happens with el pueblo who doesn't want to learn, we have to learn." These words were met with applause from the community and Oscar thanked her for being so passionate about the cause.

One woman, from the communal council located directly behind the building, was upset over the damage suffered by her community since the project had started. Her community had voted against the project when it was first initiated, three years prior, she said. "Well, the project started," she continued, and all of a sudden their houses were invaded by rats "of 
all sizes" and mosquitoes. "Our children are getting sick," she added, and demanded that the authorities fumigate the area.

I want you representatives to tell me a date or that you come and do it immediately ... because we are those who are directly affected, and there are children living there, elderly people, sick people, and we really don't deserve this, because we were those who said that we didn't want this and they did it anyway, so now you have to step up to your responsibilities ... so now I ask the community; in the same way that you supported this, now support us as well ... we are the people who live close to this, you talk about the planned surgical unit, but can you tell me what they will do with all the "things" that they take out from there?

By things, she referred to human waste and used medical material accumulating in a hospital. No other hospital in Caracas was located that close to a residential area, exactly for that reason, she exclaimed. Oscar spoke again, saying that he wanted to respond to the compañera. In a slightly polemic tone, he pointed out that the CDI was a project created to address the lack of access to healthcare that the whole community experienced. As the woman flagged that Oscar was ignoring the infestation problem she had raised, he said, "Well, let's fumigate; this is one of the problems that one has to find solutions to." He then tried to end the session, but a man, who lived nearby, intervened and said that he had lived in front of that field for 34 years and that he remembered that there had been a mosquito problem in the past as well because of a pit in the area. He hoped that the possibility of fumigation would be considered.

A man from one of the colectivos said that he had already heard that "people" were going to hablar paja (talk shit) about the initiative. "There are a lot of interests involved," he warned. "And that is why the project was stopped in the first place. People will talk shit about it to damage the revolutionary process, to damage the health committees, maybe for the purpose of obtaining political privileges," he stated and encouraged everyone present to become spokespeople for their communities, to talk to their neighbors, their friends, their boyfriends, their girlfriends, their children, about the importance of the project.

\section{Contesting the Colectivos}

Another man presented himself as being from the communal council in front of the football stadium, which is the sector that had suffered the leakages caused by the construction work. He said that, two years prior, when 
work on the CDI was about to start and Fundacaracas got involved, he was the only one to oppose the project, along with another man from his sector

because we knew what would happen here, el compañero Jaime and myself, because when Fundacaracas got involved, we knew that the project wouldn't finish, that it was demagogy ... because we were present when they promised that they would not take land from the markings of the football field, and then they took more than two meters. In this football field it isn't possible to make legal tournaments anymore, and there the problem started, because Fundacaracas ... aha, there are the skeletons (of the building), for more than two years it's been like that, and the kids living here cannot play football anymore, they have to go over to the fields in bloque 6 or bloque 37 , and besides, this is a historical site in 23 de Enero.

And the other thing I want to say is that if we are supposed to form work groups, it is necessary to have representatives from the Contraloría General de la República (General Comptroller's office) and from the municipal comptroller because the problem here is the embezzlement of the money from these constructions and in the field ... the problem isn't that these projects have to be finished, we know that they have to, and we will support that, but those who embezzled the money and those responsible within the institutions, like the municipal administration, have to go to jail, and the president of Fundacaracas, the directors, those who gave the orders. They have to go to jail because they misappropriated the money destined to the construction of these projects.

This intervention didn't get the response that one might think that it would, although some nodded. It was quite obvious that everyone knew that the money disappeared was water under the bridge, and that it would be impossible to find out who had taken it. The most pressing issue was now to move the process forward.

It soon became clear that the presence of the colectivos was problematic. A representative from one of the colectivos in the F-zone proposed that they take over the surveillance of the construction site as of the following Monday. The representative mentioned that they had a CDI in their area and that his colectivo had been in charge of security in the area since the CDI was constructed. Another man from a different colectivo intervened. He had a few things to say about the role of the colectivos in safeguarding CDIs. He said:

Look, the satanization of the colectivos has gone so far that many people think that they aren't necessary ... but if the colectivo (name removed) hadn't guarded the other CDI [in zona F], that one might also have been 
in these very conditions ... that is why this is so important and that is why I hope that you appreciate the proposal that the compañero just made, because not everyone offers to be present day and night to guard over a place like this, and we want to say to the community, be on their side, [bring them] a cup of coffee, a glass of water, whatever, so that this work is carried out...

A young girl from the barrio below the hospital then encouraged all communal councils to form an asamblea de seguridad (security assembly) so that the colectivos would not be the only ones in charge of the security issue. Another man, a representative from one of the better-known colectivos in the area, introduced himself and remarked:

Well, good evening to the whole community that is present, to the communal councils, to the colectivos. Well, I am a member of the colectivo (name removed), we have known about the problem here for a long time because we came here to do some meetings with the compañeros living here, but I think selfishness prevails here, we call for unity among all the communal councils, all people who live in this area.

The communal councils and the colectivos are about to start forming the Communes but yet we see that this CDI is in ruins and that the people living nearby have not displayed sufficient will to assume responsibility for addressing the problem. But this situation cannot be allowed to deprive the whole community of 23 de Enero and the whole of Venezuela, because as the compañero was saying previously, this belongs to el pueblo and we are all pueblo. Thus, I, as a representative for my organization, want to underscore for all the compañeros that are present here today that the revolutionary state, together with the colectivos, the communal councils and the whole pueblo of 23 de Enero, should be united in rescuing this CDI. It can't be possible that a collective service is abandoned because of the particular interests of two or three people, we all need our health.

Another thing is that the communal councils and the colectivos, through the commune, should take control over the spaces outside of here, the problems of drug trafficking and alcohol, which are creating the situation we are presented with here. Thus, we, as integrated revolutionaries (revolucionarios integrales), because we have to be integrated, have to assume this responsibility together with the revolutionary state which needs to make itself present here with all the colectivos and the whole of the parish of 23 de Enero. That was all for now. Good night.

The meeting continued for a while longer, with various people chiming in to defend the presence of the colectivos. There were also some discussions 
over whether the football field was actually being used or not. Eventually it was decided that a new meeting would be held the following Monday, and that mesas de trabajo (work groups) would be created to develop a plan with Fundacaracas. The representative from Fundacaracas promised to be present and to co-operate with the community as the process evolved, and assured the involvement of every one present in the institution in the project. The meeting ended with applause and Oscar's parting words:

Well, compañeros, this is the way to walk, hand in hand like Christ says, the revolutionaries are Christians and if we don't share like brothers this will fall apart. We have to move forward, move forward with the diversity and with the unity, if we don't unite we will continue to be poor, if we manage to unite we will achieve satisfaction for all of us. Good night on behalf of all the colectivos, all the communal councils and el pueblo in general that have been present here tonight.

\section{Forging COMmunity}

When I arrived on foot the following Monday, 70 to 80 people were gathered outside the locked gates leading to the hospital site. It turned out that those who had the keys, who seemed to be connected to Señora Yurelia, "the lady with the interests" in the nearby community, had not brought them along. People were upset and Oscar was saying that "we must condemn this; this site belongs to the community." The representative from Fundacomunal was present, and informed everyone that he believed work could start within the following two to three weeks. The groups engaged in a lengthy discussion about when the next meeting would be held, and when they could sit down in work groups. Eventually, they decided that the meeting would take place the following Sunday at $10 \mathrm{am}$. A man then asked if he could read a written statement signed by the spokespeople of various communal councils out loud.

The statement read:

We, the signatories of this letter, spokespersons of the Communal Councils, will let it be known that we do not accept the proposal made on Friday, March 20,2009, by the colectivos to take over the spaces of the CDI, and the spaces for culture and sports. The reasons for this refusal are that 1 ) the actions taken to enter the premises weren't acceptable, as the adjacent communities should have been involved and informed of the steps they were planning on taking; 2) their proposal to guard over the CDI is not agreeable for us as we are against the use of violence and guns. 
The community seems to ignore that 1 ) señora Yurelia is in charge of the baseball stadium area and it was the community that endorsed her role with their signatures; 2) we will also bring to your attention that in this stadium a junior school for baseball has been set up. Apart from what has already been said, the señora Yurelia was elected spokesperson for the sports and recreation committee in (barrio name removed) and it is she who carried out the necessary procedures with the state institutions in order to make these installations work; 3 ) in the football stadium there was a functioning football school, which was coordinated by the señores (name removed) and (name removed) and where children from the communities of (listing up the name of seven different adjacent barrios) were participating; 4) in the Theatre of (name removed), in spite of its deterioration, there are schools of theater, dancing, aerobic and an evangelical church.

Because of what has been said above, we will let it be known that we will accept the collaboration of the governmental institutions, municipality, Ministry of Health, (the presidential office) Miraflores, so that the necessary procedures are put in place to repair the CDI of (name removed) and get it up and running with the help of the community. We rectify that we do not want any colectivo to appropriate the structures that are for the use of the members of the community, in full accordance with the provisions in the article 3 of the Constitution of the Bolivarian Republic of Venezuela. In the city of Caracas, on the twenty-third day of the month of March 2009, representatives of the communities, the following signatures...

Applause followed, and then a lengthy discussion erupted. Various representatives from the colectivos spoke passionately about their disinterested and altruistic engagement in the CDI project, which in their opinion had been abandoned because none of the communities around it had showed any interest. A polemic developed between the colectivos and those who had written the statement referred to above. Tensions continued to rise until a young woman asked to speak. She said she was from the colectivo that was running a radio station from the theater that was mentioned in the letter.

We have been there for around a year, and we can assure and affirm and substantiate to everyone present that before we got there the insecurity in this zone was total, there it was only vandalism reigning, the crime, the delinquency ... and for the community living behind the theater they have to walk between there and Mercal, in fact, people were attacked in Mercal I don't know how many times, and we can affirm and substantiate that since we started to be there no one has been attacked in Mercal again, and we 
have taken care of the security in this space and around it, because many people in the community, when they have problems with the delinquency, who do they go to? To us, and we make sure that they don't consume drugs in the stairways, that they don't rob the school children, their cell phones and backpacks, that they don't attack an old lady who is passing by there, that they don't park stolen cars there or burn cars...

Another man then interjected: “And that people don't amanecen muertos (wake up dead)." The young woman continued:

That they don't ... exactly. Nothing of this has happened since we started to be there and yes, we are a colectivo ... of course we need to maintain security and we defend ourselves like one has to defend oneself against the delinquency, do you understand what I mean? Because you cannot just throw flowers to the delinquents, and we are doing it assuming the risks...

A small conversation erupted in a corner and Oscar asked everyone to keep quiet. The girl then continued:

We are doing it knowing that it may cost us, that we might lose cameradas in the intent but we are doing it anyway and we are not asking the community to confront this, but rather we are doing it ourselves ... and we are not asking for your gratitude, but you should recognize it, I mean, you cannot all the time say that they colectivos are delinquents, that they have arms ... what are we going to do if the communities aren't assuming the responsibility, if they don't have neither the balls nor the ovary to confront the delinquents...

An enthusiastic applause erupted. A man shouted, "That is the way to speak, amiga, that is the way to speak!" The young woman signaled that she hadn't finished:

Another thing: just to clarify that before these meetings here, in January and February 2008, we were in meetings here behind the CDI, with the people from the community here, including the señora Yurelia, and there we prepared some tasks for ourselves, and the community here said that they would be responsible for finding out which company did this and left it like this, that they will make social comptrollership and come back to us and inform us. We let the things pass and, look, it has been a year and we still don't know what the community actually did. 
A man said: "Nothing!" and the woman continued:

So here we are, waiting. So if the community wasn't able to take any responsibility, I am community too, I want to take responsibility for the problems, and well, I am colectivo but I am also community, and as community I am going to assume the responsibility of doing social comptrollership and involve myself in this ... well, finished, that was all I wanted to say...

After this intervention the mood changed notably. One man, from the community that the young woman had criticized, explained what they had actually done, that they had sought answers from the institutions, constantly pestered Fundacaracas to send over their inspectors, but that, at the end of the day, they didn't get proper answers. The crowd acknowledged that they had indeed done something. No more arguments broke out about whether the colectivos were to be involved or not. The meeting ended with an agreement to meet up again for roundtable work on the following Sunday, and Fundacaracas promised to bring tables and chairs.

\section{ROUNDTABLES}

The following Sunday a crowd of around 150 people showed up. Fundacaracas had brought chairs, tables and a large tent, like they promised. Mesas de trabajo (work tables) have become widely used in community work in Venezuela, as well as in public-political meetings where people discuss a new law or other political proposals. This is often called parlamentarismo de la calle (parliamentalism of the street), a term harking back to the pre-Chávez era when people gathered to discuss urgent community issues. On that Sunday, the crowd quickly split into four groups, based on their area of interest: sports, security, social comptrollership and health. Each group elected one person to write down the main points on a large white sheet and one to present the results to the crowd. I joined the group working on social comptrollership. After an hour of group work (Oscar was working hard to stick to the time schedule), the chairs were reorganized so that everyone would be facing the side of the CDI where the presenters would hang the large white paper sheet up and share the conclusions reached by each group. The main findings for each group were the following (Table 5.1): 
Table 5.1 Results from roundtable discussion in the Parish of 23 de Enero, March 2009

The health roundtable

- Develop an overview of the status of the CDI structures

- Evaluate how much time is needed in order to complete the work

- The members of the roundtable are obliged to take measures if they do not get satisfactory answers from the institutions. The measures may be: levantar una acta (make formal written complaints), go to the relevant institutions, organize a street protest, or take any other adequate measure

- Form a working group composed by everyone involved in social health work in 23 de Enero through the health committees, as well as the communal councils

- The leadership of the health group should rotate among members

The security roundtable

- Maintain security over the area

- Co-ordinate the security issue with the colectivos and the social groups in the area

- Make sure that the keys are handed over to the security group

- Improve the illumination in the area around the CDI

- Make a daily diary over occurrences around the CDI structure

- Prohibit the sale of liquor in the surrounding area

- Promote the sale of fast food instead of liquor

- Prohibit cars stationing in front of the area leading into the CDI

- Exercise territorial control together with the communal councils

- Make an inventory of everything that is inside and around the CDI building

- Make a telephone directory of everyone who will be involved in the security issue

- Improve the fence around the CDI building

The sports roundtable

- Make sure that both the football and the baseball fields are restored according to a detailed list of repairs

The social comptrollership roundtable

- Constitute a social comptrollership named Network of Social Comptrollerships Simón Bolívar (Red the Contraloría Social Simón Bolivar) composed by the four communal councils that directly border the area, by other nearby communities, by the metropolitan council representative for the parish and the local contact person (enlace parroquial) in 23 de Enero for the Libertador Municipality

- Divide the work between different work brigades

- Make an archive of all documents and document everything that has to do with institutional logistics as well as logistics in the neighborhood

- Demand immediate results from the institutions involved

- Work with everyone in a unified manner (forma mancomunada)

When all the roundtables had presented their findings, the community voted for the suggestions of each group-all of them were approved. This was then duly noted in the acta (minutes) of the event. All participants signed, thereby giving the decisions made in the assembly an appearance 
of public legitimacy. Overall, the meeting proceeded in a rather harmonious manner, and the problematic involvement of the colectivos seemed to have been forgotten. It was Felipe who ended the meeting this time. He gave a lengthy speech during which he promised to contact Electricidad de Caracas and invite them to join the initiative and put up more light posts in the area. Moreover, he wanted everyone to notice how much could be achieved if the community and the institutions moved in the same direction:

In August 2009 we will have been struggling for this CDI for three years, for it to be finished. First we observed that the construction was done wrongly, then we denounced that those who were carrying out the work weren't qualified for the job, we denounced the work inspector because he never appeared and when he did appear he just met with a little group and didn't give any answers to the community.

So we were denouncing all this, and today we see the result. What is it that we want to say with this? That through the interaction between the institutions and the communities we can recuperate our spaces; I don't have to go to Globovisión nor to Radio Caracas Televisión and complain in order to make things happen, because el camerada Oscar, el camerada Walter, my own person because I am a public functionary elected by popular vote, ${ }^{11}$ we have the obligation to support the communities, and there is another example, Gerardo that got involved today, and the other compañera as well, this is our mission and our function, we are here in order to give the communities all the necessary tools to solve their problems. And why? Because we have a leader, a leader who is giving us lineas (directions) every day, a leader that every day tells us what we need to do, and I believe....

Which is our obligation? Comply with this mandate. Why mandates? Because it is the welfare of our communities that we are fighting for. And who will bring you welfare? People from other sectors? No, it has to be us, what has happened here with this CDI really should not happen here again in 23 de Enero, it is really shameful that it happened here ... but it happened and it has given us the opportunities to have here with us the compañeros from (the Ministry) of Health, Fundacaracas, Parlamento Latino and all the other entities that have come here and that have been preoccupied with these problems ... but we will certainly move forward shortly, in accordance with the procedures that will be outlined by INAVI, I will make a promise on behalf of camerada Walter, that he will accompany me in this, Walter is a deputy in the Parlamento Latinoamericano, a neighbor from Catia, friends for all our lives, and I will publicly make this promise on behalf of him that he will accompany me doing all these procedures so that this has a happy ending. 
The meeting ended in general enthusiasm, after all had agreed that, those who could, would assist in doing the inventory of what was left of the CDI the next day.

Over the next few weeks, several meetings took place. A jornada de trabajo communitario (community work day) was arranged for a Sunday morning in order to clean up sand and dirt from the inside of the CDI. The colectivo La Piedrita had mobilized their youth group, a group of boys around 15 or 16 years old, whose members were giggling and whispering at the sight of the gringa ethnographer that was moving sand and dirty water out of the building. A group of people from the nearby communal councils also participated and, as frequently happens, they were mostly women. A Cuban team of doctors was expected later that week to inspect the site, but they had to travel to the city of Maracay, two hours from Caracas, because of a hospital building that had suffered damage during an earthquake. (Several minor earthquakes were recorded in the coastal region that spring.) The meeting was postponed to a few days later when Felipe, Oscar, a few other people from the community and I gathered. There were also two representatives from the Cuban commission in Miraflores, one engineer and the female doctor at the head of all the Cuban doctors stationed in Caracas, a representative from the company that had been contracted to repair the CDI, and a representative from the municipality. They had brought detailed drawings of the building with them, and were discussing the next steps with Oscar and Felipe, who were both extremely happy with the involvement of high-level figures. The CDI module had apparently been put on a high-priority development list by Fundacaracas. Oscar and Felipe were both duly filming the whole meeting and made everyone present sign the minutes of the meeting.

After the meeting, I spoke with Oscar and Felipe for a while. They told me that the real issue now lay with the health committee. The health committee would have considerable influence over who would be employed at the hospital (nurses, assistants, janitors and so on), once it was up and running. According to the philosophy of community development, the community was supposed to have control over these matters. In the case of construction projects, this was also a way to stop labor unions from exercising their mafia-like influence over employment decisions, or from paralyzing work, if they so wished. Thus, the employment issue stirred the community and generated quite a bit of maneuvering by those who wanted control over any hiring process. The person running the show, I soon understood, was 
once again Señora Yurelia, the lady with the baseball field and "interests," who had quite a lot of influence on the committee connected to the Barrio Adentro I health module, in front of the CDI.

\section{TOWARD THE END}

Suddenly, activities waned down. Easter was coming, and Venezuelans cherish that holiday for traveling. Many people "add on" an extra few days to the vacation, which means that everything stops both in the communities and in public institutions during the holidays, and it takes a long time before things go back to normal. Felipe and Oscar were busy organizing the traditional Easter event in their community - a march simulating the suffering of Christ on the Via Dolorosa and his death on the cross. An actor draped in white, portraying Jesus, carried a cross through the community, and people followed him in his long march. When we reached one of the chapels in 23 de Enero, a group of "soldiers" was bashing and beating him before the march resumed, up to the football stadium and outside the bloque where Felipe and Oscar lived. There he was "hung" on a large wooden cross.

Because of sudden health issues, Oscar had very little time on his hands after the Easter holiday. Thus, despite being the motor of the project, he pulled out. When I asked him, he said that the initiative had to be taken over by the community living near the CDI. He was tired of trying to move the project along. Now people in the community had to take over. Not too long after that, I returned to Norway.

\section{The End of The STORY}

When I returned, half a year later, work around the CDI was once again paralyzed. I asked Sergio, a friend from the community next to the football field, why, and he answered that they had just reconvened to get the work started once more. I tried to inquire into why the project had stopped, but he said that he didn't know. "When these things happen, it is often sabotage," he said. Perhaps the money had dried up because of the fall in oil prices that autumn, he speculated. Or perhaps it had been postponed because there had been a change in the municipal government. "The real reason for why it stopped is not known; a lot of things are being said" (se dice muchas cosas).

When I went back the following year, the CDI was finished and up and running. Sergio told me that it had been completed with money 
coming from the presidency. Someone else told me that it had been finished with money from the Ministry of Popular Power for Health. Then I asked Oscar, who had practically retired from community politics for the time being because of his personal health problems. He puffed a bit and said that the woman who controlled the baseball field had basically taken over and had been running the show. "She is a malandra (thug/bully)," he said. Besides, she had two sons who were bullying and intimidating people who dared to challenge her influence on the community. Thus, at the end of the day, she had placed her people to work in the hospital. The doctors were a mix of Cubans and Venezuelans who were "more or less attending people," according to Oscar. He had just pulled out of the process altogether: "We didn't want to exhaust ourselves there, people didn't participate. And it is difficult when you don't live exactly there in the area. It is not enough to be there every 15-20 days; you have to be there all the time to accompany people." He also said that the colectivos had stopped being involved after the first phase when they were safeguarding the security situation in the building area. "She is there with her people," Oscar repeated. "She has a lot of influence in that community."

It was difficult for me to tell whether Oscar was critical of how the hospital was working because he was still hurt for losing control over the process or there were real issues at the CDI. A woman, who had been involved in the project from the very start, told me that everything was going fine over there, that the colectivos had "pulled out" after the construction phase and that the health committees were working closely with the hospital. "Everything was going fine," she said, and people were being attended.

In October 2013, while back in Norway, I read in the online version of the daily Caracas newspaper, Correo del Orinoco, that the football field had just been finished by Fundacaracas. The field, which was now at the disposal of local children and youths, featured artificial grass and met the standards for regulation fields. It had wardrobes, toilets, and illumination for late-night use. The mayor of the Libertador Municipality, Jorge Rodriguez; the head of the capital district (Distrito Capital), Jacqueline Farías; and parish authorities were invited to inspect the football field together with the local communities. In his speech, Jorge Rodriguez said that "this is not about finally finishing the building of the field, this is just the beginning, the beginning for the football players for the future that will be formed here, the golden generation that Chávez granted us" (Correo del Orinoco 2013). 


\section{Community Action and the Politics of Space}

This chapter has illustrated the inherent challenges that popular neighborhood groups face when trying to constitute themselves as collective political subjects (Lazar 2008:58) in the context of community politics. The experiences of popular mobilization since Chávez was first elected served to create different, and sometimes competing, bases of power in the community, which in many cases clashed with one another. This was particularly the case in the parish of 23 de Enero, where the previous territorial dominance of the colectivos was partly displaced by the establishment of the communal councils. This feature was however not unique to 23 de Enero. The process of "forging a community" was an issue present in all arenas of struggle. In order to make their claims toward the state, communities were trying to present themselves as a unified political body (either as one single communal council, or as an association of several community groups, as in the case described), while, at the same time, facing internal conflicts.

As we saw in the CDI case study, the ideal of a unified, collective body of citizens, constituting itself as a community vis-á-vis the state, was clearly shaken by the de facto heterogeneity between different interests and priorities as well as positions of power and influence. Both the people with rat problems and the people with drainage problems, referenced "their community" when speaking of their damages they had all suffered, and of the right they all had to see their problems resolved. Colectivos of various kinds were constantly trying to portray themselves as "community"-in this context as safeguarders of the common interests of the whole community, and under-communicating their special and controversial status in the parish. At the same time, they tried to portray themselves as special groups selflessly attending the interests of the community in matters of public security. Oscar and Felipe on the other hand (who had little personal interests in the project besides local prestige and a desire to improve local health facilities ${ }^{12}$ ) were constantly trying to frame everything in a wider context of collective social struggle and poder popular.

Señora Yurelia, "the lady with the interests" appeared to be the winner in the end. She was tied to the Barrio Adentro health module and led the sports committee in her communal council, controlling the local baseball field: positions that gave her significant leverage in her community. Moreover, she had the advantage of spatial proximity to the site and appeared to be connected to other power bases in the community, like the local council woman.

Oscar and Felipe on the other hand, who were the ones who had initiated the process and managed to engage public and political entities, 
might have seemed like the individuals who could have gained the most recognition and influence over the process. However, the fact that they lived elsewhere (approximately $1 \mathrm{~km}$ away) provided them with a weaker claim to represent local interests and less chances of ganarse los espacios (gain the spaces) through close interaction with local residents. This illustrates the symbolic importance given to space, as well as how community politics and the politics of local recognition are closely tied to a personal relationship with the space-confirmed by the need to be present, visible and ganarse los espacios.

What this case showed is thus the multi-faceted notion of community as it is used in Bolivarian political discourse. Community is a context-specific self-explanatory concept as well as an ambivalent concept that can be used strategically in order to substantiate claims to legitimacy both within the community and toward the state. In spite of the local conflicts simmering below the surface, people were capable of calling upon the notion of community in order to make their claims toward the state representatives. Their claim to represent the health interests of 23 de Enero (and other parishes as well, indeed the whole pueblo, as Felipe said) alluded to the government policies of paying up a social debt to poor communities. They could therefore draw on a broader conundrum of political discourses and symbolism when they staked out a position for themselves as the legitimate protagonists of bringing this process forward. All along, in the conversation with public representatives, they underscored their prerogative not only to participate in the planning process, but also to have a final say in how it would proceed. Similarly, the state representatives explicitly recognized the crowd and its inherent collective political qualities, attributing them not only with the right to make claims toward the state in the name of "the community" as a whole, but also with the right to participate in the process itself.

However, as this example and subsequent discussions will show, "the community" had few chances of actually enforcing its legally sanctioned right to influence and shape public policy. The CDI project was probably delayed for reasons far beyond the community's reach. There was a change in municipal administration at the time, which implies that the majority of institutional personnel are changed (see Chap. 10) as well as an overhaul of municipal budget. This illustrates the fragility of community-initiated politics, an issue that will be further discussed in the following chapter where we will explore the insides of the Venezuelan state. 


\section{Notes}

1. "The community" is a contentious concept in scholarly writing (e.g., see Cohen 1985), and some scholars have suggested that the concept should be abandoned altogether (Young 1986 in Creed 2004:57). However, in spite of its ambiguity, "community" will inevitably be used in this discussion. Not only is it a concept that is frequently used in local discourse, but it is also the concept that best encompasses the social setting that we are trying to get a grasp on. However, I am not presupposing that it is possible to understand a "community" a priori, or that the emic usage of the word presupposes a coherent or stable idea of what a "community" is.

2. This was passed as a law in 2006, with the title Ley Especial de Regularización Integral de la Tenencia de la Tierra en los Asentamientos Urbanos Populares (Special Law for Integral Regulation and Land Tenure in Urban Popular Settlements).

3. According to Article 2 of the Law for the Communal Councils: "The Communal Councils, within the constitutional framework of a participative and protagonistic democracy, are instances of participation, articulation and integration between the citizens and the various community organizations, social and popular movements, which allow the organized people to exercise [as a] communitarian government and [the direct exercise of] public policy and projects oriented towards responding to the communities' necessities, potentials and aspirations in the construction of the new model of a socialist society of equality, equity and social justice." Author's translation from Spanish. The full law text can be found at http://www.minci.gob.ve/2012/09/ley-organica-de-los-consejoscomunales/.

4. These are the executive committee (unidad ejecutiva), the communitarian financial and administrative unit (unidad administrativa y financiera comunitaria), and the unit for social comptrollership (unidad de contraloría social).

5. The five motors are la Ley Habilitante (the enabling law), to grant the president the power to enact radical reforms; la Reforma Constitucional Socialista (the Socialist constitutional reform), which Chávez lost narrowly in 2007; la Educación Popular (popular education), an educational program that teaches Socialist, anti-imperialist and anti-colonialist values; la Nueva Geometría del Poder (the new geometry of power), which radically changes territorial and administrative structures in order to facilitate social and political development in an endogenous manner; and el Poder Comunal (the communal power), making popular power a backbone of the affairs of the state, through communal councils, communes and so on. 
6. However, the constitutional base is legitimized in paragraph 70 (GarcíaGuadilla 2008:8), which states that "Participation and involvement of people in the exercise of their sovereignty in political affairs can be manifested by: voting to fill public offices, referendum, consultation of public opinion, mandate revocation, legislative, constitutional and constituent initiative, open forums and meetings of citizens whose decisions shall be binding among others; and in social and economic affairs: citizen service organs, selfmanagement, co-management, cooperatives in all forms, including those of a financial nature, savings funds, community enterprises, and other forms of association guided by the values of mutual cooperation and solidarity. The law shall establish conditions for the effective, functioning of the means of participation provided for under the present article." See Constitution of the Bolivarian Republic of Venezuela (1999).

7. Now called Ministerio del Poder Popular para la Comuna y los Movimientos Sociales.

8. All costs associated with the stay at Cuba are paid by the agreement, including for a relative to accompany the patient.

9. Manuel Rosales was the former governor of Zulia who lost the presidential elections in 2007, and who fled to Peru seeking political asylum after he was charged for extensive corruption during his time as a governor.

10. Here clarification is needed. Chávez set up a special unit linked directly to the president's office where people could come and complain about problems they may have with the public institutions. The president's office then called up the relevant institutions and commanded them to resolve the problem. The office was located in the White House, an impressive palace building guarded by the presidential army vis-à-vis the presidential palace Miraflores. Anyone could line up in the queue and have their complaint registered, and people came from all over the country to do so.

11. Felipe held an elected position in the local circuit of PSUV.

12. I can say this because I came to know both of them very well over time.

\section{BiBLIOGRAPHY}

Aguiar, Asdrúbal. 2007. Los cinco motores de la Revolución en Venezuela. Analitica. http://www.analitica.com/opinion/opinion-nacional/los-cincomotores-de-la-revolucion-en-venezuela/. Accessed February 20, 2017.

Alvarez, Rosángel, and María Pilar García-Guadilla. 2011. Controlaría social y clientelismo: La praxis de los consejos comunales en Venezuela. Politeia 34 (46): 175-207.

Auyero, Javier. 2001. Poor People's Politics. Peronist Survival Networks and the Legacy of Evita. Durham and London: Duke University Press. 
Brouwer, Steve. 2011. Revolutionary Doctors. How Venezuela and Cuba Are Changing the World's Conception of Health Care. New York: Monthly Review Press.

Ciccariello-Maher, George. 2013. We Created Chávez: A People's History of the Venezuelan Revolution. Durham and London: Duke University Press.

- 2016. Building the Commune. Radical Democracy in Venezuela. London and New York: Verso.

Cohen, Anthony. 1985. The Symbolic Construction of Community. London and New York: Routledge.

Constitution of the Bolivarian Republic of Venezuela. 1999. Article 70. http:// www.venezuelaemb.or.kr/english/ConstitutionoftheBolivarianingles.pdf. Accessed February 20, 2017.

Correo del Orinoco. 2013. Sierra Maestra tiene su estadio de fútbol. Correo del Orinoco, October 21. http://www.ciudadccs.info/?p=491568. Accessed December 20, 2013.

Creed, Gerald. 2004. Constituted through Conflict: Images of Community (and Nation) in Bulgarian Rural Ritual. American Anthropologist 106 (1):56-70.

D'Elia, Yolanda, and Luis Francisco Cabezas. 2008. Las Misiones Sociales en Venezuela. Caracas: Instituto Latinoamericano de Investigaciones Sociales (ILDIS).

Duno-Gottberg, Luis. 2009. Social Images of Anti-Apocalypse: Bikers and the Representation of Popular Politics in Venezuela. Contracorriente 6 (2): 144-172.

García-Guadilla, María Pilar. 2007. Ciudadanía y autonomía en las organizaciones sociales bolivarianas: Los Comités de Tierra Urbana como movimientos sociales. Cuadernos de Cendes 24 (66): 47-73.

- 2008. Poder popular y límites de democracia participativa en Venezuela: la experiencia de los Consejos Comunales. Paper delivered at the II Conferencia of the Venezuela Section of Latin American Studies Association (LASA), Caracas, May 2008.

Gledhill, John. 1994. Power and Its Disguises. Anthropological Perspectives on Politics. London: Pluto Press.

Goffman, Erving. 1956. The Presentation of Self in Everyday Life. New York: Doubleday.

Hawkins, Kirk, Guillermo Rosas, and Michel E. Johnson. 2011. The Misiones of the Chávez Government. In Venezuela's Bolivarian Democracy. Participation, Politics and Culture under Chávez, ed. D. Smilde and D. Hellinger. Durham and London: Duke University Press.

Lazar, Sian. 2008. El Alto, Rebel City. Self and Citizenship in Andean Bolivia. Durham and London: Duke University Press.

Martinez, Carlos, Michael Fox, and Jojo Farell. 2010. Venezuela Speaks! Voices from the Grassroots. Oakland: PM Press.

Maya, Margarita López. 2011. Hacia el socialismo del siglo XXI: Los consejos comunales, sus cambios conceptuales y las percepciones de los participantes en Caracas. In Ciudadania y Legitimidad Democrática en América Latina, ed. I. Cheresky. Buenos Aires: Prometeo. 
Moreno, Marco Aponte. 2008. Metaphors in Hugo Chávez Political Discourse: Conceptualizing Nation, Revolution, and Opposition. PhD dissertation, Graduate Faculty in Hispanic and Luso-Brazilian, City University of New York.

Nichols, Elizabeth Gackstetter, and Kimberley J. Morse. 2010. Venezuela. Santa Barbara, California, Denver, Colorado and Oxford, England: ABC-CLIO.

Nuijten, Monique. 2003. Power, Community, and the State. The Political Anthropology of Organization in Mexico. London and Sterling, VA: Pluto Press.

Républica Bolivariana de Venezuela. 2007. Proyecto Nacional Simón Bolivar 2007-2013. http://www.psuv.org.ve/wp-content/uploads/2011/03/ProyectoNacionalSim\%C3\%B3n-Bol\%C3\%ADvar.pdf. Accessed February 20, 2017.

Strønen, Iselin Åsedotter. 2006. "For Us This Is Utopia Coming True.” Venezuela's Bolivarian Revolution and Popular Movements in a Caracas Barrio. MA thesis, Department for Social Anthropology, University of Bergen.

- 2012. Development from Below and Oil Money from Above: Popular Organization in Contemporary Venezuela. In Flammable Society. Studies on the Socio-economics of Oil and Gas, ed. J.-A. McNeish and O. Logan. London: Pluto Press.

Valencia, Cristobal. 2015. We Are the State! Barrio Activism in Venezuela's Bolivarian Revolution. Tucson: The University of Arizona Press.

Velasco, Alejandro. 2015. Urban Popular Politics and the Making of Modern Venezuela. Oakland: University of California Press.

Wilpert, Gregory. 2011. Venezuela's Experiment in Participatory Democracy. In The Revolution in Venezuela. Social and Political Change under Chávez, ed. T. Ponniah and J. Eastwood. Cambridge, MA: David Rockefeller Center for Latin American Studies, Harvard University.

Ystanes, Margit. 2011. Precarious Trust. Problems of Managing Self and Sociality in Guatemala. PhD dissertation, Department of Anthropology, University of Bergen.

Open Access This chapter is distributed under the terms of the Creative Commons Attribution 4.0 International License (http://creativecommons.org/ licenses/by/4.0/), which permits use, duplication, adaptation, distribution and reproduction in any medium or format, as long as you give appropriate credit to the original author(s) and the source, provide a link to the Creative Commons license and indicate if changes were made.

The images or other third party material in this chapter are included in the chapter's Creative Commons license, unless indicated otherwise in a credit line to the material. If material is not included in the chapter's Creative Commons license and your intended use is not permitted by statutory regulation or exceeds the permitted use, you will need to obtain permission directly from the copyright holder.

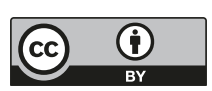




\section{The State as a Battlefield}

It was Saturday afternoon. I was sitting outside one of the cafés in Zona $\mathrm{F}$ in 23 de Enero with Miche and Adrian, having a beer. Both were experienced revolucionarios, having been trained as cuadros (cadres) in the revolutionary youth organization Frente Francisco de Miranda. For several years, they had worked in different government institutions echandole bolas (lit: throwing in balls, fig: working hard). For them, working with the state was a political and ideological task. Both believed in the necessity of profound changes and in the paramount importance of changing the state from the inside in order to create a new Bolivarian state and society.

Both Miche and Adrian had grown up in a barrio and were high-school dropouts, living with their single mothers and extended family, forced to start working at an early age. Even if they had always had an ideological affinity with anti-imperialist and popular sector struggles, they had not become really politicized until Chávez arrived on the scene after the 1998 election. At the time, they were part of the first wave of new political organizations: Miche was part of the Bolivarian Circles, and Adrian of a cultural group in his community. He made magic happen with his African drums, and the group he was a part of was occasionally hired as "musical entertainment" for those who wanted a "folkloric touch" at high-class parties in the eastern part of the city.

Both Miche and Adrian had become radicalized after the 2002 coup. They were part of the popular resistance during those chaotic days, driving around on motorbikes and mobilizing people to demand Chávez's return. Afterward, both of them went to Cuba with Frente Francisco de Miranda. 
Frente Francisco de Miranda is a youth organization that was established by a joint agreement between Fidel Castro and Hugo Chávez in 2003 in order to educate a new generation of Venezuelan civil servants. The students-mostly young people-were flown to Cuba where they lived on campuses while following an intense educational program in history, political science, public administration, economics, political ideology as well as personal development. The organization describes itself as:

A political organization-disciplined, anti-imperialist, dynamic and organized: fundamental in the struggle for eradicating poverty in all its manifestations and for achieving social equality in Venezuela. It is an instrument that supports the missions and contributes to the successful development of the programs incited by the Revolutionary Government, to benefit the most humble classes, in correspondence with the Bolivarian ideal and the thinking of Comandante Chávez. We are in every corner of the country day by day, giving our lives for achieving a more just society, filled with solidarity, fraternity and dedicated to disinterested humanitarian aid without expecting nor receiving anything in return apart from the prosperity of our country. (Frente Francisco de Miranda n.d., author's translation from Spanish)

The educational program was free of charge, and the students received a minor scholarship for personal costs. For many poor youth, this was their first trip outside Venezuela, and for rural students, sometimes their first trip to central Venezuela. The classes in Cuba were called avanzadas, and the intense period of close-quarter living in dormitories and around-the-clock studying-often over several months-generated strong sentiments of collectivity and friendships as well as a close identification with "their" avanzada class, which were maintained in the years even as Frente Francisco de Miranda as a mass movement as such fell more or less apart (see below).

Miche and Adrian were part of one of the first avanzadas, and because they displayed talent, both of them returned to Cuba for shorter and more selective classes in administration and leadership. Back in Venezuela they were involved in building the Frente's headquarter in Gato Negro, Catia, as well as working with several government ministries.

When I met them, they were both working in Fundacomunal. Miche was planning on quitting: he had had enough. "I feel like an accomplice. I can no longer justify that I have to answer, 'I don't know' to my community," he said. "His community" was the area where he worked with the communal councils. He had long been frustrated because those higher up in the system in Fundacomunal helped neither him nor the community, 
and he was the one who had to face the members in the communal council every week with an "I don't know what is happening."

Adrian agreed that it was difficult to defend the status quo. They witnessed revolutionary fervor being replaced by struggles for power, inefficiency and opportunism, which represented a serious threat to the political future of the Bolivarian revolution. The old vices of the state inherited from the Fourth Republic had not only remained, but they had also contaminated the revolutionary process from within.

They were both critical of their workplace, as a proper critical revolutionary in their opinion should have been, but they both knew that if they voiced their frustrations too loudly, they would get in trouble. It had happened to them both before. Miche had denounced corruption in another organization and had been pushed out, though very subtly. Adrian had quit a former job because he was treated badly by a superior with friends in high places and had suddenly found himself in a situation where he had great difficulty in getting a new job. Because of their attitudes, they had not been allowed to advance despite their having been chosen as "selected potential leaders" when they first started.

Both Adrian and Miche were tired of all the shortcomings within the political administration and state bureaucracy. It also filled them with profound sadness. They both described the early years after 2003 as the best moment of their lives. They had been part of the wave of revolutionary spirit and new policies in the wake of the 2002 coup and had participated in making wonderful things happen. Both of them had traveled across the country to remote countryside villages and backward middle-of-nowhere sites, day and night, and had helped setting up the missions and issuing identity cards through Misión Identidad. ${ }^{1}$ They had sacrificed romantic relationships and family, a decent salary and a good night's sleep for years. And they weren't the only ones. Thousands of youths had become mobilized. There had really been a mass movement, a mass enthusiasm, a sense of family. And now they felt that this enthusiasm to a large extent had withered away.

Much of this was due to the bureaucracy, which they viewed as the tranca de piedra (sand in the machinery) of the revolution. Adrian was waiving his beer as he was presenting his favorite metaphor to describe what was happening: the hamburger bread and the meat. The community was the bottom piece of bread, and the president was the top piece of bread, where the policies benefiting the communities were emerging from. In the middle you had a huge hamburger which was the bureaucracy, filled with vicios (vices). Because of this dysfunctional bureaucratic hamburger, 
the policies that were meant to benefit the communities didn't filter down the way they were supposed to. And that was the biggest threat to the revolution, Miche and Adrian agreed on that.

In the foregoing chapter, I started my exploration of community politics in the barrios. I analyzed the ways in which popular struggle played out within what I have termed a Bolivarian space: a political space of interaction between state and grassroots movements, drawing on templates of popular sovereignty and the state's historical debt to the poor. In the following two chapters, I will continue my inquiry into the political and everyday encounters between popular sector communities and the Venezuelan state under Chávez. The broader analytical ambitions with these chapters are twofold: one is to understand state practices and state dynamics from the pre-Chávez era, and how these vestiges were contested, challenged and reproduced during the Chávez era. That is, I am interested in the political and temporal interface between the state of the Fourth Republic and the emerging state of the Fifth Republic. The second analytical ambition is to understand how the popular sectors pushed from below to transform the "old" state according to Bolivarian ideals, and to explore the strategies they used. At the heart of these processes were attempts to make "the state"we will come back to the theoretical implication of studying "the state" below-less opaque, less corrupt, less patronizing, less hierarchic, less clientelistic, and more open to popular demands, knowledges and socialities.

I do not claim that these negative dynamics and characteristics attributed to the Venezuelan state are unique to Venezuela. Rather, Latin American states-to various degrees - share a host of similar characteristics. This has its root in their genesis as colonial and later post-colonial states, and how processes of state formation were taking place in societies sharing many similar features. Thus, in many respects, this account says something about Latin American state formations in general, and many of the challenges encountered by Bolivarian activists are parallel to those of their fellow comrades in other countries (e.g., see Lazar 2008). However, the ethnographic moment and context studied here is unique in the sense that it represents a particular historical constellation of political ideas and social forces: that is, the Bolivarian process. Through exploring the frictions, contradictions and struggles emerging as the ideals of the Bolivarian process rubbed against ingrained social practices and heterogeneous interest 
and ideologies, we are better equipped to understand both the Bolivarian process' particularities and the inherent complexities in processes of political and social change.

\section{TheOrizing THE StaTe}

Adrian and Miche's story tells a tale of a short-term political trajectory within the early years of the Bolivarian revolution. It also conveys a deeper script about the quest to transform not only state praxis, that is, how the state functions, but also to change the meaning of the relationships between society and the state.

Scholarly inquiries into the state throw up a host of theoretical implications. Of particular relevance to our context is, how can we understand the relationship between the state and society, and how do we understand power and resistance both inside and outside the state? Anthropological theory-production about the state has problematized and criticized Foucauldian and Weberian approaches to the state that pose state and society in a dichotomist relationship. For Foucauldian-inspired scholars, the state derives its power and its appearance as a bounded totality through the aggregated diffusion of impersonalized rule, institutions and procedures - that is, governmentality (e.g., see Foucault 1991; Mitchell 2006). To Weberian scholars, "the state appears monolithic to society because its work follows certain impersonal, rational and standardized routines which give it a sui generis quality" (Neuman 2005:195). In both cases, the state appears as a bounded locus of power, set apart from society.

Anthropological scholars on the other hand, have argued that how the state appears, and how people view the state and position themselves in relation to it, is essentially a case of empirical inquiry. Gupta (1995), for example, asks whether the Western legacy of universalizing a dual cultural construction of state-society relations stands up to scrutiny in the face of "incommensurable cultural and historical contexts" (Gupta 1995:214). Drawing on ethnography from India, he argues that "we should leave open the analytical question as to the conditions under which the state does operate as a cohesive and unitary whole" (Gupta 1995:229). Nuijten (2003) makes a similar argument when she teases out a duality in the way Mexican peasants both engage with and imagine the state. Power is not an abstract formalized rule, but rather a myriad of changing strategies that are personalized and continuously reinvented (Nuijten 2003:120). At the same time, she argues that governmental techniques such as stamps, maps 
and official terminology contribute to the preservation of the myth of bureaucratic rule and the appearance of a coherent system (Nuijten 2003).

\section{Hegemony and Practice}

Anthropologists perceive of the state as a set of institutions, strategies and practices as well as an idea and ideological construct (see also Abrams 1988 [1977]; Blom Hansen and Stepputat 2001; Krohn-Hansen and Nustad 2005; Sharma and Gupta 2006). This is important for our ethnographic explorations, because it allows us to understand the Venezuelan state from various angles. "The Magical State" as a megamonolithic representation of power as sketched out by Coronil as well as the highly personalized inroads and dynamics within the Venezuelan state bureaucracy that we have already started to analyze are two valuable analytical inroads. However, the implicit conceptualization of the state and its relationship to society undercutting popular sector agency is also of crucial importance to our exploration. At times, people invoked an imagery of the Venezuelan state as a monolithic apparatus. This imagery was shaped by the state's projection of itself-its imaginary state-craft-as well as by subjective encounters through which the state had rendered visible its exclusionary boundaries. At the same time, through its lack of Weberian systems of governance, it was also perceived of as a domain with the potentiality to be penetrated through social relations and practices traversing state-society boundaries. Moreover, people understood the state as a condensed site of power stratifying and organizing the diffusion of power throughout the rest of society. And, vice versa, as an instrument of power that different groups in society tried to seize in order to consolidate their power on other social, economic and political arenas. That is, the state is an amorphous entity, appearing as a different beast in different contexts and from different viewpoints. This is reminiscent of what Gupta quotes Donna Haraway on stating, "there is obviously no Archimedean point from which to visualize 'the state,' only numerous situated knowledges" (Gupta 1995:229).

Valencia argues that in order to understand the slogan "We Are the State!" as often uttered by Chávez's grassroots supporters, we need to do a "critical rereading of Gramsci's notion of hegemony and its relationship to culture" (Valencia 2015:17). His contribution is important because it highlights that the state is a site for the construction of hegemony. The popular sectors' attempt to transform the state from below was derived from a keen understanding of the state's role in shaping how "various relationships 
of subordination work" (Crehan 2002:105). As Scott (1985) has showed, resistance can come in numerous forms, open and covert, creatively reinvented and transformed in the course of different contexts and changing contour of domination. In the context of the Bolivarian process, popular sector activists were faced on the one hand with a seemingly benevolent state that professed - at the level of government ideology-that the state was theirs to appropriate and transform. On the other hand, people were keenly aware that the de facto transformation of the state implied challenging both concrete practices and institutionalized networks of power-both sympathetic to and in opposition to the government-as well as the cultural hegemony ingrained in the state. This duality, of the personalization and porousness of state power at the level of everyday practices, as well as the imagery of the state as a site of domination, is central for understanding how the state became an epicenter for struggle during the Bolivarian process.

\section{TAKING OVER THE STATE (?)}

The picture becomes even more complicated when we try to understand how and to what extent the Chávez government was actually able to assert power over the state. As Hansen and Stepputat note:

Political power does not mean that a new government can change institutional routines overnight or that social practices within the bureaucracy can be easily modified. The state is an enormous and amorphous mechanism that functions along a whole range of discrete and often self-perpetuating logics, bereft of any unifying an encompassing rationale. (Blom Hansen and Stepputat 2001:28)

They suggest that in order for a new political regime to successfully reach its objectives, it needs to design and implement a fairly coherent state project that involves "thoroughgoing institutional reforms and a certain reinvention of the state" (Blom Hansen and Stepputat 2001:29). However, more often than not, this does not happen, implying that "most contemporary societies remain governed by yesterday's administrative systems and procedures" (Blom Hansen and Stepputat 2001:29). The consequences of multiple "incomplete overhauls" by new regimes are that state systems are shaped by multiple sets of sediments of governance:

Each new regime builds a number of new institutions and nurses particular areas with greater care and zeal, often reflecting the larger ideological for- 
mation and communities out of which they have emerged. (Blom Hansen and Stepputat 2001:30)

Moreover, different parties cultivate particular ties of loyalties and patronage to different parts of the state system, leading to an additional "zonification" and fragmentation of the bureaucratic apparatus (Blom Hansen and Stepputat 2001:30). These insights are crucial for our context. Popular politics and state reforms in the Chávez era were taking place within a highly conflictive terrain, with a variety of actors and interests both within and outside the realm of the state. In addition, the government built up a host of new institutions and structures, exactly in order to "by-pass" the pre-existing structures that they knew were extremely difficult to reform and gain control over. This produced an additional fragmentation and "zonification" of the state that made the enactment of government reforms a challenge.

Indeed, an inquiry into the Venezuelan bureaucracy to a certain extent debunks the popular myth that Chávez and his government wielded excessive power over the state bureaucracy. The Venezuelan state is historically imbued with "non-Weberian" dynamics in the sense of being a site of personalized and highly fallible bureaucratic practices. These practices became even more complicated as the Venezuelan state under Chávez became a conflictive site for new and old networks of power, some resisting and some reproducing entrenched state practices, and all of them intensely competing for power. These insights provide a clearer picture of why political reforms enacted from above were so difficult to enact. It also helps us understand why popular sector activists insisted on popular struggle as the key to the advancement of the Bolivarian process. The Venezuelan state would not transform itself on its own. It could only be transformed through sustained pressure and popular struggle from below in a prolonged Gramscian war of position as well as war of maneuver.

\section{Structure, Agency and Habitus}

Inquiries into human interaction with external structures will always bring up the eternal debate about the relationship between structure and agency. It will become clear from my ethnographic exploration that I attribute to the Venezuelan state a considerable power over reproducing habitus (Bourdieu 1979), even in the midst of radical change. In Bourdieu's own words: "the habitus, the product of history, produces individual and 
collective practices, and hence histories, in accordance with the schemes engendered by history" (Bourdieu 1979:82).

However, even as the schemes of the Venezuelan state as engendered by history, to paraphrase the quote above, appear to be resilient in many ways, I will illustrate the micro-processes of change taking place in different fields through the flow of new policies, reforms, discourses and configurations of new political and social actors. In Nuijten's interpretation of Bourdieu's concept of field

agents and institutions constantly struggle, according to the regularities and the rules constitutive of this space to appropriate the specific products at stake in the game. Those who dominate in a given field are in a position to make it function to their advantage, but they must always contend with the resistance, the claims, the contention, of the dominated. (Nuijten 2003:13)

Moreover, in different agents' quests for conquering that field, they deploy the forms of capital (Bourdieu 1986) that correspond to that field. The historical conjuncture and the processes at play that are analyzed in this book might be cast as a reorganization of fields, and forms of capital that correspond to them, as different social actors tried to appropriate new political spaces within the Bolivarian process. Concretely, the discursive and political potency of the ethos of "popular power" constituted a new form of political and symbolic capital that was used in various ways by different actors to gain leverage, prestige and influence.

\section{Organizing Power (s)}

Wolf argues that if we want to understand power, we need to start with history and processes of organization of power. Organization, he argues, "sets up relationships among people through allocation and control of resources and rewards" (Wolf 1990:590). At the same time he cautions that organization is always at risk; as power balances shift and change, power never reaches its final form of organization (Wolf 1990:590). As I outlined in Chap. 2, the history of the organization of the Venezuelan state through different power arrangements can be captured through different time frames, each of them showing processes of continuities as well as discontinuities. ${ }^{2}$ This is also the case with the Chávez epoch.

Changes under the Chávez government, in spite of being frequently referred to as a "Bolivarian revolution," were not a revolutionary process, 
but a reformist one. While a true political revolution implies "a rapid, basic transformation of a society's political structures" (Thomassen 2012:683), the Chávez government left political structures intact or sought to reform them from within while simultaneously building new, parallel structures. ${ }^{3}$ New legislation invested new forms of responsibilities, ends and means into existing institutions, while new institutions were being created in order to implement political reforms. At the same time, the Venezuelan state apparatus was in many respects left unchanged, permeated by old (in parallel with the new) power structures, personnel and institutional practices. While these inter- and intra-institutional struggles-intrinsic to any process of regime change-were evident at the level of day-to-day politics, they also gave way to a new understanding of the battle for hegemony over the political domain played out between the "old state" and the ideal vision of the reformed Bolivarian state.

At the heart of this process was the popular day-to-day struggle for appropriating the political space that was opened up by new legislation, policies and political discourse. It is to the day-to-day reality that I will now turn. However, I believe that it is appropriate to start "from the top," with a broad overview of core issues related to the Venezuelan state system and how it relates to the broader process of political struggle and reconfigurations of power.

\section{Venezuelan State Practices}

As is common in other Latin American countries, the political and administrative bureaucracy in Venezuela is highly personalized and revolves around personal networks and alliances. A number of middle- and highlevel executive positions in the state and government apparatus (the socalled cargos 9.9) come with the clause that the new person in charge is allowed to change the key personnel working directly under her. These positions are called los cargos de confianza (positions of trust). That means that every time a key managerial position changes, the team supporting it also changes. That is why you often hear employees saying: "Yo entré por..." [I entered through...], meaning that you were brought in by the new person in charge. Moreover, if a new political actor wins an election to the parish, the municipal administration or governorship, the staff and service providers corresponding to the office is also by and large changed.

These practices have a range of implications. For one, they open up ample space for shady decision-making processes, including "corruption" 
(see Chap. 10), as positions of power are built around networks of people with loyalty to one or a set of managers or leaders. Moreover, the constant change of personnel implies a lack of knowledge transfer, as the people who were formerly staffing the office all leave, and the new ones do not necessarily know the area they will be working in. During the Chávez era there was a high turnover of both ministerial positions, a series of reorganizations of ministries and institutions, and a high degree of turnover in executive positions at various levels. I repeatedly saw how projects in the communities fell apart because there had been a change in positions, either in a political or in an administrative office. Often grassroots activists had spent a lot of time cultivating relations with political figures and state officials. But when positions were changed, their contact person and leverage also disappeared, and they had to start pushing to find another opening within the office they were dealing with.

Such practices also have the consequence that many state jobs are highly unstable, and people cultivate a range of different connections and networks within the state bureaucracy in order to ensure their future (see also Nuijten 2003). This creates strong and crosscutting alliances within the state system, which people also can rely on in order to get their job done. At the same time it should be said that internal recruitment procedures are not solely based on personal and political connections. Job performance does also play a role, though you often need someone to give you an opportunity and open the door for you; you need a door opener.

\section{The Practice of the Palanca}

In Venezuela, a door opener is called a palanca (lever). Palanca is an expression that denotes the practice of "knowing" someone on the inside in order to obtain something. That something may be a service, an operation at the hospital, a studying coupon at the university, a job or a bank credit. The practice of using a palanca implies that those who don't have a palanca will end up at the bottom of any priority list (e.g., a list of job applicants or a list of patients that have to undergo surgery). The social activist Rafael Gustavo González describes the culture of la palanca as follows:

The palanca doesn't only move the world, loosens up bolts and opens padlocks, but it gets anything. The culture of the palanca has been elevated in every sense to the point that the use and abuse of it has become com- 
monplace. Let's look at these expressions: Quite a trunk of a palanca you have! You surely got this with a palanca! Don't worry mum, I already got into university because I got a palanca! This is my friend Pepe who I told you about who has a really good palanca in the ministry! Look, Mary, don't forget to call Rosita who has a godmother who is friend of a doorman who has contact with the manager who serves you as a palanca! The palanca that I have is really good, I am sure to get that job. (González 2013)

The "acquisition-by-palanca" is part of virtually all spheres of society. It is possible to obtain things without a palanca, but a lot more insistence and effort are required. From an anthropological point of view, we can posit that doing a favor as a palanca amounts to an exchange similar to Marcel Mauss's (1954) gift. One the one hand, a palanca can be a formal agreement, even implicating an economic compensation. But it is most commonly tied to core social obligations inherent in close relationships between kin, friends and networks. Serving as palancas for one another, constitutes a vital part of how social relationships are forged. Thus, the practice of the palanca is part of an expanding web of networks of exchange - amounting to a time-diffuse but persistent presence of expectations of reciprocity. If I draw on your nephew's uncle's contact within the university in order get admitted into a master's program, it establishes me in an undefined relationship of reciprocity, with you or someone in your friend's networks.

Of course, this ties nicely with the common perception of Latin American states as infused with practices of corruption, nepotism, patronage, clientelism and amiguismo. I will not embark in that discussion here, as it would require going back to the historical context surrounding Venezuelan, and Latin American in general, state formations. Moreover, "corruption" will be thoroughly discussed in Chap. 10 where we will also look more closely into state practices and political imaginaries associated with corruption at large.

What I want to highlight however, is that the practice of the palanca has generated a state bureaucracy that is filled with spiderweb-like networks of loyalties and connections. Thus, while key political positions are appointed from the top (from the ministry), political power is not total. Rather, power is also filtered and diverted through co-existing or competing fiefdoms within the bureaucracy.

The palanca also creates dynamics whereby the state bureaucracy is filled with "fictitious positions" — positions that are created because some- 
one (sometimes unqualified and unmotivated) managed to get a job by using the right connections. This, as anyone who has dealt with Latin American bureaucracies can testify to, sometimes provides for bureaucratic encounters that makes you reach for both Kafka and Dante in order to conceptualize your sentiments. On a more serious note, it also evidently taps the state bureaucracy for resources and hampers public service performance.

\section{Fiefdoms AND NeTWORKS}

The sindicatos (labor unions) are also powerful actors within the public institutions. They control hiring, and backed by strong Venezuelan labor laws, they also make it highly unlikely for people they protect to be fired. To be protected by the union is also a matter of cultivating networks and palancas. To have a job with the Venezuelan state is extremely desirable. According to labor laws, people with a permanent employment contract within the state are entitled to new employment, should their job become redundant. Public employment also provides good welfare benefits in the form of health insurance, bonuses and pension. In some cases, public positions can even be transmitted from parent to child.

It is a common claim of the opposition that the Chávez government purged state institutions from opposition members. In my experience that is far from the truth. I have come across non-sympathizers to the government in all kinds of government institutions as well as in political offices, including the vice-ministry. As people often obtain positions through family, friends or a palanca, political preferences may not be relevant. Many people have also been employed by the state for years or decades, and cannot be removed because of Venezuelan labor laws. The union power networks often pre-date the Chávez era, and are powerful blocs that may, or may not, be effectively in opposition to the government. "The old personnel" pre-dating Chávez may also cultivate personal ties and networks with new leaders and power networks where political preferences are irrelevant or under-communicated. Personal, political and strategic networks are not necessarily determined by partisanship, and political power is far from hegemonic. Rather, the political field, in the broad sense, is guided by highly complex dynamics between new and old power networks, institutional mechanisms and legislation, and ingrained social practices traversing state-society boundaries. 


\section{The Labor Conflict in Fundacomunal}

A couple of years ago a labor conflict emerged in Fundacomunal. ${ }^{4}$ A new director, appointed by the head of Frente Francisco de Miranda, was put in charge of its main Caracas office, located in Catia. The new director was bent on reforming the institution from within, well aware of both its political importance-as the institution works closely with the communal councils-and its internal problematics, in the form of inefficiency, internal conflicts and, in some cases, incompetent and unmotivated personnel.

The institution's long history, originally founded by Acción Democrática in the 1960s, implied that it was filled with "superfluous" personnel. Some of the newcomers, who had entered the institution after the Chávez government assumed power, had also adopted a "non-conscientious" approach to their work. In the words of one of their former co-workers: "The only thing they did was to raise their pay-check and smoke marijuana in La Guaira." Eventually the new director fired a group of four to five people, from both the old and new guard. The group hired a lawyer, pulled strings within the institution, and went to the Ministry of Popular Power for Labour (Ministerio de Poder Popular Para el Trabajo) to complain over the alleged unlawful dismissal.

However, since early 2003, during the oil strike/lock out, the Chávez government had repeatedly renewed the decree of immobilidad laboral (labor immobility). The decree implied the temporary suspension of the right to dismiss employees, both in the private and in the public sector, unless the termination was on the grounds of a breach of contract (failure to fulfill work duties, criminal activities and so on). The reason for these measures was that during the strike, merchants and business owners from the opposition started to fire Chavista sympathizers en masse. In order to put an end to this, the immobilidad laboral was announced, and later renewed.

The highest authority in disputed dismissals is the Ministry of Popular Power for Labor. In the Fundacomunal firing case, the ministry of labor voted in favor of the discharged workers because the director had allegedly not filed the case properly. Fundacomunal was forced to compensate them for the unlawful dismissal with a year's salary, and to reintegrate them into the work force. The case had received massive public attention because the discharged workers had gone to the opposition media and complained, claiming to have been fired for political reasons. Eventually, the director was forced to resign from her position, officially, because she had not consulted her superiors before making the decision to dismiss 
them, unofficially, because of the negative publicity the event had brought upon Fundacomunal, and which she was held responsible for.

Thus, as this case shows, "Chavista-power" in state institutions was far from hegemonic. Rather, political intrigues, personal connections, laws and institutions steered events in one direction or another. Many people (bitterly) complained that adecos and copeyanos were more protected in the state institutions than the Chavistas, as the latter were newcomers and often on temporary contracts. The "old guard" on the other hand was safely protected by labor laws and long-established networks of power. It was a source of anger that, in labor conflicts, opposition supporters used the opposition media to give the impression that they were being fired for political reasons-while it might have been because of incompetence or other justifiable reasons for dismissal. The main opposition channel, Globovision, was in particular notorious for making a media circus out of any case that could portray the government as authoritarian or discriminatory.

As the government was wary of such media campaigns, people started claiming that the public institutions avoided firing people who should be fired, keeping opposition supporters in state jobs, from which they could continue hampering and subverting the Bolivarian process from within. As one government worker formulated it:

We have this fear of confronting the Right ... but if we don't transform [the state], if we don't have people that are really capacitated, people with a compromise and conviction capable to transform [the institutions], then we keep on maintaining the old, we keep on feeding the old, strengthening the old, and the old keeps on existing.

Government supporters, on the other hand, could be more easily dismissed or mistreated, as they would not "run off" to Globovision and complain, out of loyalty to the public image of the government.

\section{The Endogenous Right}

During the Fourth Republic, access to jobs in the state apparatus was based on allegiance to the dominant parties, Acción Democrática and COPEI. Doors were shut for those who were not affiliated with these parties and, to a large extent, these jobs were unavailable for the popular classes. In the course of the Bolivarian process, a new generation of state employees was formed consisting of people with a leftist or lower-class 
background. To a certain extent, this changed the rules of the state game, at the same time as it created a conundrum of highly conflictive and multifarious dynamics within the state and the political sphere of the Bolivarian space.

The old layers of the state bureaucracy were often referred to as los adecos (sympathizers/loyalists to Acción Democrática), or los cuartarepublicanos (those from the Fourth Republic). These were perceived of as saboteurs of the Bolivarian processes, not only because they might deliberately sabotage the execution of government's policy, but also because they were accustomed to a state culture of corruption, inefficiency and sloth. However, popular sector activists and conscientious public officials also felt that they were struggling on another front, namely against what was referred to as la derecha endogena (the endogenous right). La derecha endogena were people who might pose as fervent revolutionaries, but who in effect were more concerned with attending to their own ambitions and desires. Through not implementing reforms, plans and projects, they were sabotaging the process from within. Acting as if they supported the Bolivarian process, they could opportunistically plot their own schemes and build up their own (equally opportunistic) networks, squeezing outthrough dirty maneuvering - those who conscientiously sought to implement and act in accordance with "Bolivarian" principles and ideals. The presence of the endogenous right and opportunists within state institutions was perceived of as one of the greatest threats to the Bolivarian process, because it defamed the government in the eyes of the public and effectively sabotaged the advancement of popular sector struggles to appropriate the political space made available through government policy.

Additionally, people were concerned with the emergence of a new bureaucratic and political cast called the Boliburgesia (a combination of the words "Bolivarian" and "bourgeois"). Gossips of lavish spending, generous benefits and accumulation of private fortunes among "revolutionary leaders" were widespread both in the communities and among lower-rank employees. This was taken as evidence of how the old vices of the Venezuelan state-that is, the tradition of using state positions for private rent seeking - had gotten hold of revolutionary hearts and minds.

\section{The Fragmented State Arm}

Through these accounts of the inner dynamics of the Venezuelan state bureaucracy, a picture of a highly fragmented "executive arm" of government power emerges. The hierarchical structures, social practices and 
cultural meaning historically inscribed in the state bureaucracy was both reproduced and challenged, giving way to intense struggles both from within and the outside of the formal corridors of bureaucratic and political power. Constant battle between new and old networks of power, conflictual loyalties, personal interests and ideological positions evolved in the midst of attempts to implement new political reforms that at any rate would have demanded a lot of cohesive bureaucratic co-ordination and effort.

As I quoted Blom Hansen and Stepputat on saying above: "The state is an enormous and amorphous mechanism that functions along a whole range of discrete and often self-perpetuating logics, bereft of any unifying an encompassing rationale" (Blom Hansen and Stepputat 2001:28). Historically, the Venezuelan state was constituted as a site for shoring up political power and amassing personal wealth. (This is further discussed in Chap. 10.) As a negative mirror image of the bureaucratic Weberian ideal type, the Venezuelan public servant was perceived of as being unresponsive and unaccountable to public service, and with an explicit class bias excluding the popular sectors. People intuitively attributed the state a strong ability to reproduce this kind of behavior (or habitus, one could say); once people got on the inside of the state system, they were caught up in the inner logics and behavioral expectations inscribed in the state system. To the popular sector, their struggle was thus a matter of challenging the cultural hegemony and accustomed practices inscribed in the state itself, at the same time as they battled against their own "fifth columnists"- the Boliburgesia and the endogenous right - and the old layers of the Venezuelan state from the Fourth Republic.

\section{Chávez’s Scolding}

The discrepancies between political ideals and realpolitik was far from lost on lawmakers, who were working on developing legislation in different arenas to facilitate popular participation in state politics. One member of the National Assembly, speaking on conditions of anonymity, expressed great concern over how the state institutions were managing their dayto-day contact with the communities, arguing that the institutions were still often circumscribing and manipulating popular power. He criticized the simplified vision of popular power that prevailed in state institutions (see Fernandes 2010 for an analysis of the neoliberal rationalities of the Venezuelan state), estimating success on the basis of the number of proj- 
ects developed and the money spent, rather than on the basis of an integrated vision of popular empowerment and increasing autonomy from the state:

My perception is that things are not going as they should, though we are ok if we measure the advancement of popular power through obras (projects), for the things that they do with the money that they solicit and are granted. Why ok? Because, for example, if they elaborate a project to construct 20 houses to improve the life quality of 20 families they may even stretch the money to constructing 23-34 houses, they are efficient in that way. But this is not the kit of the revolution, or in other words, the kit of the revolution is not that the pueblo administers the state's resources.

The revolution is about people governing in an integrated manner, do you understand? [The idea about the revolution] is developed from an endogenous point of view, to improve their life conditions, to establish a system of communal economy that makes them less dependent on minimas publicas (public grants) and which helps them to construct a socialist society of equity, justice and rights ... that is why I cannot measure the advancement of popular power [in money] ... and that seems like what they are doing now, they measure it in the amounts transferred, but the money is just a resource that is justified by the projects, but the real benefit is in the achievements, in that the projects are generating the happiness of people, and not the money for the money's sake. That is my preoccupation.

This was in 2010, when the communal councils were a key focus area for the government. The deputy attributed much of the problems related to the implementation of these to the internal politics and culture of el Frente Francisco de Miranda, who was put in charge of managing the ministry and corresponding institutions responsible for working with the poder popular. El Frente, as it was normally called, was led by Erika Farías, a woman originally from Catia, a popular neighborhood in the west, who slowly, but surely, had climbed the ranks within the Bolivarian revolution. Many complained that under her, el Frente had been streamlined into a highly hierarchical and politically partisan organization, which had also made it lose its original appeal to young people from different political backgrounds and with different political viewpoints. Moreover, Farías was said to be an astute politician with a talent for securing her own power base, which translated into a very hierarchically organized ministry with institutions run by people loyal to her.

People often pondered over whether Chávez was informed well enough of what was going on, and most concluded that he wasn't. People thought 
that he was too trusting of his government ministers and therefore failed to pick up on what was going on within governmental institutions and "on the ground." As one man commented: "Lo tienen engañado" [they have him fooled]. In November 2009, it seemed as if the news of popular discontent over how the institutions were working had also reached Chávez. In a live episode of Aló Presidente, he subtly, but firmly, interrogated Erika Farías about what was going on in her ministry, and lashed out on the "bureaucratism" that was creating obstacles to people's efforts in organizing themselves. Even if people were used to Chávez interrogating ministers in public, after the live show, it was obvious that he was well-informed and upset about the problems between the public institutions and the communal councils, and sending Farías a not-so-subtle message about putting her own house in order. After that, Farías wasn't seen publicly for some weeks, and the institutions started to frenetically engage with the communal councils and approve projects that had been lingering for a long time.

This episode presents, very clearly, the image people had of Chávez as the embodiment of government power, yet incapable of actually controlling the state itself. People often said they felt sorry for Chávez who wanted to do so much good, but was sabotaged by the people that should have been working for him. That also explains why people like Adrian and Miche were fighting as best they could. In spite of the difficulties within the institutions, they felt that if ideologically committed people gave up and resigned, the state would be left to demagogic, opportunist and selfserving people who would make the revolution wither away from within.

\section{The Opaqueness of the State}

Caracas, 2011: One Thursday evening, I show up at seven o'clock in order to attend the meeting in the communal council. I had just come back to Venezuela after a year in Norway. When I had first spent time with them a year ago, they were about to get the communal council up and going. At the same time, there was also a lot of buzz around the new municipality's flagship program, Plan Caracas Socialista. This was a plan for urban rehabilitation of barrio communities, which would be developed in close co-operation by the municipal government and popular sector organizations. La Cañada would be the pilot project for the plan. For that purpose a gabinete sectorial had been organized-a coordinating forum for the different community organizations in this area. The municipal- 
ity also designed an enlace parroquial (a person that would co-ordinate municipality and community organizations).

I find the group outside the headquarters of the local colectivo. Last time I saw them, when they were about to organize the communal council, they were holding meetings at the local school, located next to one of the bloques. Then, 15 to 20 people were attending. Now it's only 5 to 6 , most of them the same community activists that have been gathering since long back.

As we wait for Roberto, the undisputed leader of the group, to sit down so we can start the meeting, I ask Irene about how things have been and how the work is coming along. She sighs and shakes her shoulders: "There is a lot of apathy in the community," she says. I ask about Plan Caracas Socialista and she answers that they didn't fulfill their promises. They did a bad job, and continued in the Zona Central before they finished here. "Jorge Rodriguez didn't show his face again," she says, referring to the kick-off meeting that they had with Jorge Rodriguez last year, when he promised that Plan Caracas Socialista would be the Municipal flagship program and that he would personally see to it. At the time it was even said that the mayor was taking secret trips to the area at night in order to see how things were proceeding.

Irene says that they have been sending letters to the Alcaldia and have tried to talk to them, but to no avail. Now Fundacaracas has taken over. As always, money is the issue; she sighs and shakes her head as in, "what can you do?" "It ended up being a white elephant," she says dryly.

But this week she has been called up by Fundacomunal. Suddenly they got a plumbing project approved. Fundacomunal had demanded to have some papers about the communal council saying that "they should have had them yesterday." Irene sighs again over this, because this whole process means that she has to open a new bank account, as Fundacomunal made their deposits in a different bank from that of the municipality. That meant that the whole process of paper work would have to be done all over again. "Why can they not just use the same bank account?" she complains again. Marta, a short woman in her 60s with indigenous traits, also comments on how difficult it is and how little help they feel that they are getting. She does however feel that the barrios are getting more help than the blocks, and she wonders if this is because they are in more dire need of help. However, both of them agree that they are a bit worn out in general. It feels like they have to knock on doors and hunt down decision-makers and decisions and information all the time and they just don't have time for that. 
People knew from experience that their everyday interaction with the state was precarious. The state could suddenly "withdraw" and make itself unavailable, projects could stop, employees could say one thing and do another, meetings could be canceled, personnel could be changed, money could run dry and political processes could be sabotaged. Rumors and speculations abounded about what was going on within different government ministries and different institutions, who were on their way out and who were on their way in in executive and public positions, which decisions Chávez was pondering, and which funds were being released somewhere in the system.

The people I met with on that Thursday evening knew that they were subject to a series of abstract decision-making processes that went beyond their comprehension and reach. In an article from South Africa, Jensen (2001) describes how failed security reforms in the post-apartheid regime was attributed to remaining agencies of the apartheid's security apparatus, called the Third Force. Over time, Third Force became more a concept than a reference to a specific agency, or what Laclau calls "an empty signifier" (Jensen 2001:117). The "Third Force" functioned as a catch-all explanatory narrative of struggle "where everything working against "the people' is placed" (Jensen 2001:117). In a similar fashion, popular sector activists kept referring to "the bureaucracy" and "the institutions"-the key "catch-all explanatory narratives" which were constantly invoked as the reasons for everything that went wrong and their frustrating challenges with the state bureaucracy.

\section{The Penetrable State}

To a certain extent, these notions reflected an imagery of the state as a monolithic site of diffuse but palpable governmentality. By making people wait, by keeping people in the dark, and by suddenly making decisions taking people by surprise, state institutions demonstrate their power (Auyero 2011). However, to paraphrase Gupta (1995:229), it is an analytical question when and under which conditions the state does appear as a cohesive and unitary whole. Accordingly, I will suggest that "seeing the state" (Scott 1999) as an enclosed site of power did not preclude that they also saw it and knew it for what it was: an incoherent apparatus of uncoordinated institutions and organs, of personal fiefdoms and hierarchical networks, of fragmented and incomplete information. For that reason, people continued to push their case, make phone calls, draw on contacts, 
and write letters (while others got frustrated and worn out). Like in the case of the CDI in Chap. 5, suddenly a door could open, the right buttons could be sufficiently pushed, the right person could get interested, Chávez or a minister could say or do something decisive, or the insistence and continuous presence of those involved was enough for the state to be engaged once more. In her case study of peasant organizations and the state in Mexico, Monique Nuijten (2003) argues that the efforts to connect with the state seldom pay off. In Venezuela, the picture wasn't that gloomy. Often, efforts to connect with the state, via formal or informal channels, did pay off, even though it required a lot of efforts.

As Grindle and Nuijten's note for Mexico, the state apparatus is so vast that most people "know someone" within the bureaucracy who can be mobilized. Grindle reports that most middle-class people have held a position in a political or governmental office at some point in their life, or they have had a family member or compadre in one (Grindle 1977:56, cited in Nuijten 2003:154). In the case of Venezuela, an increasing number of popular sector families now also had family, friends or relatives holding a position in political or governmental offices. Furthermore, the political alignment between the government and popular sector activists implied that, over the years, strategic bonds and alliances had been forged between state officials and local communities. Often, state and political officials appeared in public meetings where they could be approached, and the ideological ethos of popular power provided community activists with a discursive and political leverage. All in all, these changes made the state potentially accessible - if they were able to get a foot in the door.

Carmen, a community activist in 23 de Enero, expressed these efforts "to find a way in" in a very matter-of-fact way one evening, when we were talking on a basketball field while we waited for a meeting in the community council to start. She and her friend Belkis had been the pioneers of community work in their area, and their first project had been to fix the basketball court, complete with a mosaic of Bolívar, that we were standing on. "But I was practically stalking (former mayor of Caracas) Barreto to get the money," she said. At every public meeting Barreto held, she tried to give him a letter or talk to him. She explained that they had just gotten word that the money was within reach, when there was a change of administration, and the other guy ${ }^{6}$ took office, "and you know," she sighed. Eventually, they managed to get money for the project from the Libertador Municipality, with the help of a local and well-connected resident. 


\section{DraWING ON NETWORKS}

It is not my intention to suggest that the political and state institutions did not initiate and carry out projects and policies in shantytown communities on their own account or that the communal councils did not have their project approved unless they were able to hunt down significant politicians or state bureaucrats. However, what I want to highlight is that the ability to push the right "state buttons" is a central factor for explaining why bottom-up initiated community politics unfolded in such a heterogeneous manner in different areas. As we will learn more in the following chapter, a community council's ability to push their project through depended to a certain extent on the capacity and conscientiousness of the public official that had been assigned to help them in the process. The community's own organizational strength and "social capital" was also shaping their ability to access state funds and strengthen their political momentum. Moreover, the state institutions also at times identified "priority areas" that were assigned particular attention.

To illustrate this point, I'll use the example of a meeting with a colectivo in 23 de Enero. The colectivo was having a meeting to organize a gran mega jornada integral. Jornada is a term describing a fair where different government services and products are present. For example, jornadas of large-scale sales of food, through the distribution chain Mercal, are occasionally organized in open public spaces, especially before Christmas. This gives people the opportunity to do their Christmas shopping (a major cost for lower-income families) at discounted prices. For this local mega jornada, they were planning on having military enrollment opportunities arranged, free vaccines, sale of the new government-produced mobile telephone, Vergatario, a stall where people could issue new cedulas (identity cards) and sale of food through Mercal. They also wanted to arrange a salsa concert in the evening, and had invited one of the musicians from Grupo Madera (a famous band that has also made "jingles" for the government) to join the meeting. The musician present from Grupo Madera said that the group would be happy to participate and that they were always in favor of working with the communities. Personally, he didn't work for the government, but he had friends that did and that could get a hold of the equipment for the event. "This is the political work that the government workers have to assume," the musician said. The group started to discuss whom they could use as a connection. "Deputy Chino Jose Khan is responsible for this area," the musician said. Giorgio, the 
leader of the local colectivo, answered that he had his telephone number. He had tried calling him, but the deputy had not answered. He had also tried to call Valentin, the influential leader for the colectivo La Piedrita, for two months, but he hadn't picked up either. The musician mentioned that he knew the deputy's assistant, Carmencita, to which Giorgio responded that they knew her as well, but that "she has forgotten one's face." They then mentioned Robert Serra (who was later brutally murdered), another of the deputies with close bonds to 23 de Enero, and Giorgio said that he would be responsible for making contact with him. They then agreed that they still needed to find a way to get a hold of Chino Khan.

As this ethnographic example shows, people draw from the mechanisms that have always characterized the informal dynamics of the Venezuelan state apparatus, using personal contacts and finding ways to engage central decision-makers. In many ways people take it for granted that "this is the way things work." At the same time, as we will discuss further below, people's expectations for state accessibility and accountability, or what in Venezuelan terms is dar respuestas (give answers), was increasing as community self-consciousness, and the political ethos of popular power, translated into a redefined vision of what the state, and its representatives, should act like. These changing expectations constituted one of the key levels of negotiation that shaped the interaction between communities and state and government bodies.

Some activists complained that 23 de Enero (where the example above is taken from) received an un-proportional amount of government attention and resources, not only because its fame and relative proximity to the city center gave it a status as a "showcase community," but also because its residents were well-connected through political networks dating long back. To a certain extent this is true; 23 de Enero was granted several large projects and did have its public services significantly expanded. On the other hand, this also happened because the grassroots networks and organizations were organizationally prepared to collaborate with the state institutions - though organizational capacities were distributed unevenly across the community. In spite of the state apparatus' frequently fallible and erratic maneuvers, there was also a keen understanding of the importance of nurturing popular power in an organic and gradual manner. If money and projects were assigned to communities that were organizationally unprepared, money would be squandered and the projects would fall apart. At the same time, the state also was organizationally and politically deficient in following their politics and policies through. As we will discuss 
further in Chap. 7, the implementation of new public policies and political directives was therefore guided by careful considerations of what was organizationally and politically feasible, as well as the messy and often contradictory realities of the political game and state action.

\section{INSTITUTIONAL INERTIA}

In an article from South Africa, Jensen poses the question of how a political party can bring about reforms at the level of the state (2001:97). As the African National Congress (ANC) swept to power in 1994, the party was determined to use the state as an instrument for a complete overhaul of society. The South African and Venezuelan cases have similarities. First, the ANC perceived the state as a tool to be deployed by a political party in order to promote the interests of the people. Second, the perception of the "old state" was one of an apparatus designed to protect the interests of a minority (the white in the South African case, the bourgeois and the elites in the Venezuelan case), providing the newcomers with the legitimate right to rule and reform the state. However, as Jensen demonstrates, political reforms were not enacted in the form that the ANC had envisioned. Rather, transformations came about "through very localized, not always heroic, power struggles" (Jensen 2001:97). He argues that "bureaucratic knowledge and experience inscribed in institutional practices produce inertia within institutions that are very difficult to change" (Jensen 2001:107).

This is an observation that can very easily be applied to the Venezuelan case. By looking at the state bureaucracy we realize that the state is not guided by a single coherent political line, but rather consists of a multitude of overlapping, contested and unbounded fields. There are often enormous contradictions and discrepancies between the government's political vision and its ability to implement it. While governments may aim at creating a new state order with institutions that respond to the citizens' needs and the implementation of new legislation, it may be hard to put such political ambitions and directives into practice. Transformation takes place in a number of arenas, through a multitude of everyday struggles, with conflicting interests and shifting alliances within, outside and between the realms of the state and the realms of the popular sector. It leads to the formation of new social relations and new configurations of power and alliances that aren't necessarily in accordance with the new political discourse, and where individual interests compete with visions of collective change. 
In Chap. 7, we will explore how people were actively contesting the hierarchical nature and cultural hegemony inscribed in the Venezuelan state. Drawing on the political, social and cultural knowledges and socialities of the popular sectors, people were trying to push state and political actors into complying with the Bolivarian ethos of a popular takeover of the state. I will start by exploring the role of the so-called promotores integrales-public officials assigned to work closely with popular sector communities through the communal council. I will argue that their role took place within a hybrid interface (Long 1999) ${ }^{7}$ where "state power" and "popular power" met on a day-to-day basis, carving out a negotiated and contested space for popular sector politics within the realm of the state.

\section{Notes}

1. Misión Identidad was a program designed to give identity documents to all citizens, including foreigners living undocumented in the country. The program was carried out by visiting remote areas with mobile units and setting up temporary offices throughout the country.

2. See also Joseph and Nugent (1994), Nugent (1997, 1998), Starn (1999) for explorations of Latin American state formations.

3. Chávez's bid for constitutional reforms in 2007 represented a quest for gaining popular approval for radical reforms-a proposal that the electorate turned down with a narrow margin.

4. Although this is a publicly known event, I have chosen not to go into details about the office and individuals involved. This account is the result of interviews and conversations with various people close to the center of events.

5. La Guaira is the coastal strip around the airport Maiquetia.

6. Juan Barreto was followed by Antonia Ledezma, who represents the opposition.

7. Long describes interfaces as "point where different, often conflicting, lifeworlds or social fields intersect, or more concretely, in social situations or arenas in which interactions become oriented around problems of bridging, accommodating, segregating or contesting social, evaluative and cognitive standpoints" (Long 1999:1).

\section{BIBLIOGRAPHY}

Abrams, Philip. 1988 [1977]. Notes on the Difficulties of Studying the State. In The Anthropology of the State. A Reader, ed. A. Sharma and A. Gupta. Oxford: Blackwell Publishing. 
Auyero, Javier. 2011. Patients of the State: An Ethnographic Account of Poor People's Waiting. Latin American Research Review 46 (1): 5-29.

Bourdieu, Pierre. 1979. Distinctions. A Social Critique of the Judgment of Taste. Cambridge, MA: Harvard University Press.

- 1986. The Forms of Capital. In Handbook of Theory and Research for the Sociology of Education, ed. J. Richardson. New York: Greenwood.

Crehan, Kate A.F. 2002. Gramsci, Culture and Anthropology. Berkeley: University of California Press.

Fernandes, Sujatha. 2010. Who Can Stop the Drums? Urban Social Movements in Chávez' Venezuela. Durham and London: Duke University Press.

Foucault, Michel. 1991. Governmentality. In The Anthropology of the State. A Reader, ed. A. Sharma and A. Gupta. Oxford: Blackwell Publishing.

Frente Francisco de Miranda. n.d. Que es el Frente. http://frentefranciscodemirandasocopo.blogspot.no/p/quienes-somos.html. Accessed February 20, 2017.

González, Rafael Gustavo. 2013. La palanca. Aporrea, June 20. http://www. aporrea.org/actualidad/al69067.html. Accessed February 20, 2017.

Gupta, Akhil. 1995. Blurred Boundaries: The Discourse of Corruption, the Culture of Politics, and the Imagined State. In The Anthropology of the State. A Reader, ed. A. Sharma and A. Gupta. Oxford: Blackwell Publishing.

Hansen, Thomas Blom, and Finn Stepputat. 2001. Introduction: States of Imagination. In States of Imagination. Ethnographic Explorations of the Postcolonial State, ed. T.B. Hansen and F. Stepputat. Durham and London: Duke University Press.

Jensen, Steffen. 2001. The Battlefield and the Prize: ANC's Bid to Reform the South African State. In States of Imagination. Ethnographic Explorations of the Postcolonial State, ed. T.B. Hansen and F. Stepputat. Durham and London: Duke University Press.

Joseph, Gilbert M., and Daniel Nugent. 1994. Everyday Forms of State Formation. Revolution and Negotiation of Rule in Modern Mexico. Durham and London: Duke University Press.

Krohn-Hansen, Christian, and Knut G. Nustad. 2005. Introduction. In State Formation. Anthropological Perspectives, ed. C. Krohn-Hansen and K.G. Nustad. London and Ann Arbor, MI: Pluto Press.

Lazar, Sian. 2008. El Alto, Rebel City. Self and Citizenship in Andean Bolivia. Durham and London: Duke University Press.

Long, Norman. 1999. The Multiple Optic of Interface Analysis (Working Title). UNESCO Background Paper on Interface Analysis, October. http://lanic. utexas.edu/project/etext/llilas/claspo/workingpapers/multipleoptic.pdf. Accessed February 20, 2017.

Mauss, Marcel. 1954. The Gift: Forms and Functions of Exchange in Archaic Societies. New York: W.W. Norton. 
Mitchell, Timothy. 2006 [1999]. Society, Economy and the State Effect. In The Anthropology of the State. A Reader, ed. A. Sharma and A. Gupta. Oxford: Blackwell Publishing.

Neuman, Iver. 2005. 'A Speech That the Entire Ministry May Stand For': On Generating State Voice. In State Formation. Anthropological Perspectives, ed. C. Krohn-Hansen and K.G. Nustad. London and Ann Arbor, MI: Pluto Press. Nugent, David. 1997. Modernity at the Edge of Empire. State, Individual and Nation in the Northern Peruvian Andes, 1885-1935. Stanford, CA: Stanford University Press.

Nugent, Daniel. 1998. Rural Revolt in Mexico, U.S. Intervention and the Domain of Subaltern Politics. Durham and London: Duke University Press.

Nuijten, Monique. 2003. Power, Community, and the State. The Political Anthropology of Organization in Mexico. London and Sterling, VA: Pluto Press. Scott, James. 1985. Weapons of the Weak. Everyday Forms of Peasant Resistance. New Haven and London: Yale University Press.

- 1999. Seeing Like a State: How Certain Schemes to Improve the Human Condition Have Failed. New Haven and London: Yale University Press.

Sharma, Aradhana, and Akhil Gupta. 2006. The Anthropology of the State: A Reader. Oxford: Blackwell Publishing.

Starn, Orin. 1999. Nightwatch. The Politics of Protest in the Andes. Durham and London: Duke University Press.

Thomassen, Bjørn. 2012. Notes towards an Anthropology of Political Revolutions. Comparative Studies in Society and History 54 (3): 679-706.

Valencia, Cristobal. 2015. We Are the State! Barrio Activism in Venezuela's Bolivarian Revolution. Tucson: The University of Arizona Press.

Wolf, Eric. 1990. Distinguished Lecture: Facing Power-Old Insights, New Questions. American Anthropologist 92 (3): 586-596.

Open Access This chapter is distributed under the terms of the Creative Commons Attribution 4.0 International License (http://creativecommons.org/ licenses/by/4.0/), which permits use, duplication, adaptation, distribution and reproduction in any medium or format, as long as you give appropriate credit to the original author(s) and the source, provide a link to the Creative Commons license and indicate if changes were made.

The images or other third party material in this chapter are included in the chapter's Creative Commons license, unless indicated otherwise in a credit line to the material. If material is not included in the chapter's Creative Commons license and your intended use is not permitted by statutory regulation or exceeds the permitted use, you will need to obtain permission directly from the copyright holder.

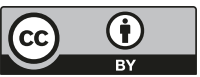




\section{Negotiating the Popular and the State}

Caracas, 2009: I could see that Miriam was about to work herself up. We had gone to the Military Museum in 23 de Enero for a large community meeting. The theme for the meeting was how the communal councils were to adapt to the new law for the communal councils that had just been passed. ${ }^{1}$ On the way out Miriam was stopped by a woman from a nearby communal council. The woman was already quite agitated, shouting that people in the communities were fed up, that they had handed in projects, but that nothing happened. "What does one have to do," she shouted. "Go to the offices and get naked? The bureaucracy is killing the revolution, the revolution is here, with Chávez," she said, touching (or rather beating) her chest. "But this is destroying the process." Miriam asked what they had done, where they had handed in projects, "because here I am, jalando bolas (dragging their balls) for the community to hand in projects." "We have handed them to the municipality," the woman answered. "But not to Fundacomunal?" Miriam inquired. "No," the woman said. "Why not, if you had handed the project to Fundacomunal, you would have gotten your pavement by now." "But that is the problem," the woman shouted, "they tell you to go to Fundacomunal, to the municipality, to the ministry, to the presidency, but what, this is the problem!"

The discussion continued, back and forth for a while; they spoke about a letter that had been handed in, about a project that had been handed in, about a temporary halt of the funding of housing projects in order to incite people to develop other projects as well. Miriam told her that rather than formandome peos a mi (scold me) at the community meeting,

(C) The Author(s) 2017

185

I.Å. Strønen, Grassroots Politics and Oil Culture in Venezuela, DOI 10.1007/978-3-319-59507-8_7 
she should rather go to Fundacomunal, to formar peos there, so that the complaints were made visible to the institutions. "The problem is a lack of response from the institutions," she said. "Look, like I am telling you, the other day we got a hold of la Corporación de Servicios, and they got their ass moving; don't you see that they are working? Why? Because in that meeting we had with them, all of us were all over them." She was referring to the service branch of the municipality in charge of garbage collection and cleaning. In a meeting the other day the community and Miriam herself had been telling them off, demanding better services.

Afterward Miriam and I walked home together; both of us living only ten minutes away. She was really upset. "I get angry really fast, I am the one that got shouted at," she says, maintaining that the real problem was that the institutions high up didn't dar respuestas (give answers). "And besides, now I have to organize yet another meeting because many of my communal councils didn't show up." Miriam was responsible for all the communal councils in the whole of 23 de Enero. I asked her if she had asked to get a co-worker to help her out. "Yes, but they just say that 'you can do it.' I have walked all day in the street, since 8 o'clock (12 hours), and now I get home and my husband is there with his cara de culo (literally: ass face) ... I am quitting, I will look for another job.”

In Chap. 6, we sketched up the conflictive and contradictory faultlines between the ideals of the Bolivarian process and the messy reality of how it actually unfolded within the domains of the state. Drawing on emic conceptualizations of the root causes of all the problems- "the endogenous right," "the boliburgesia," "los cuartarepublicanos," "the institutions," "the bureaucracy"-a quite gloomy picture emerged of a state that was caught up in its own power dynamics rather than executing state policy. Moreover, a picture was also painted of a political process and ideology that was incapable of superseding the exclusionary and hierarchical nature of the political domain that it so strongly criticized. However, while popular sector activists experienced many challenges, they also experienced many small and big victories. Concurrently, while the state in many respects was characterized by structural inertia and deep contradictions between ideal and practice, the Bolivarian process did also carve out a host of new practices, rationalities and cultural politics into the state body.

In order to get a better grasp on these complexities, this chapter is dedicated to delving deeper into state-society interaction within the Bolivarian 
space. I will explore the multiple struggles and strategies deployed by ideologically oriented grassroots activist and public officials in order to convert the ideals of the Bolivarian process into everyday political practice. Invoking the ethos of popular power, people were confronting and contesting the exclusionary and hierarchical practices of the Venezuelan state. At the same time, the rationalities of state governance was put up against popular knowledges in a process that was eclipsed by the Bolivarian government's political ideology of transferring state power to el pueblo soberano (the sovereign people). Concretely, this ideology was manifested in policies and directives that in its legal framework and in its ideological framing had the potential to empower popular power at the expense of state power. However, as Ferguson (1994) also shows from his influential account from Lesotho, policies tend to take on a life of their own when faced with complex material, political and social realities. In a similar fashion, the participatory politics promoted by the Chávez government generated new and contested dynamics both within the state institutions and in the communities when the policies were sought carried out in practice.

\section{Betwixt and Between: The Promotores Integrales}

We will start our exploration by continuing to focus on Miriam, who is introduced in the vignette above. She is an example of the many highly conscientious and ideologically oriented public sector workers that truly believed in the ideals of the Bolivarian process, and who became central for defending government policy inside the state institutions and in converting it into reality in popular sector communities. Her job was to be a promotor integral in Fundacomunal, the "front line" public employees that were working directly with the communal councils. Her task was to help them with whatever challenges they were facing: organizing and constituting themselves, developing and executing projects, or resolving internal problems and quarrels in the communities. In spite of her frustrations, Miriam didn't quit her job as she fretted over above, and over the years I often followed her throughout her workday, both in the communities, in public meetings and visiting public institutions. The demands put on her and her co-workers were not easy. The promotores were poorly paid, and it was an exhausting job, both mentally and physically. They had to subir cerro (climb shantytown hills) by foot, be in the baking sun, take buses and metros, use toilets and ask for water in private barrio homes. At the same time they had to fill out paperwork to prove that they were attending to the communities, and participate in political and public meetings and training sessions. 
I suggest that the promotores occupied an ambiguous betwixt-andbetween position in relation to the communities and the state. They came from poor communities, and many of them worked in their own communities, or in those nearby. At the same time, they were at the bottom of the institutional hierarchy and their experiences and field observations were often ignored by their superiors. This positioned them in a difficult situation in the communities. People viewed them as "agents of the state" who could help in getting projects approved, while many promotores actually had little influence over which projects were approved. These decisions were made elsewhere, higher up in the system, through a process that was often intransparent to the promotores themselves.

This ambiguous social and professional positioning implied that many of the promotores had a dual identity with regards to whom they felt that they were most closely identifying with or representing: the communities or the state. Like Miriam was saying above: "In the same way you are formandome peos a mi (scolding me) here, you have to go to Fundacomunal to formar peos there." What she meant was that castigating her at the meeting in the community did little good. Rather, the communities, or the woman in this case, would have to approach Fundacomunal's offices directly in order to make their complaint visible to the institutions. Through this statement, Miriam signalized that she felt she neither embodied, sympathized with, nor had control over the "institutions." Rather, state power was located elsewhere, and the communities had to make their anger visible where that power held seat, namely in the institutions; in "the realm of officialdom."

\section{Miriam's RoAd to Revolution}

Miriam was constantly frustrated over the way the institutions were working. For her, working with community organizations was deeply political and personal. Her motivation came from her love for Chávez and her belief in the revolution, and despite not being well versed in political theory, she had a keen intuitive understanding of the politics of class, of Latin America's colonial and imperial history, and of the transcendental role of the state in concretizing social transformation. But above all, she was an idealistic pragmatist, and she confronted her numerous daily challenges with a sarcastic attitude and a big heart.

Miriam was a middle-aged woman, married to a taxi driver and mother of two teenage daughters. In many ways, she was a representative of the female backbone supporting the Bolivarian revolution; she was one of 
those numerous popular sector women who had experienced a political awakening with Chávez's arrival on the political scene (Fernandes 2007; Rakowski and Espina 2011; Motta 2013; Strønen 2013).

Her journey toward becoming a "revolutionary" had been long. As a young woman, she had started hanging out in 23 de Enero when she met the man who later became her husband, a native of 23 de Enero. There, she witnessed el Caracazo and later joined the political mobilization around Aristóbulo Istúriz, who served as mayor of Municipio Libertador for La Causa $R$ in the 1993-1996 period.

And when the things with Chávez started, that is when I really got strengthened, and I got really, really strengthened .... and when the coup, when they took Chávez, that was when ... how do you say it, it's like, when something is taken away from you, when someone dies, that is when you really value that person ... when I felt that they took Chávez away from me, it was like they took our soul away.

That is when I really got strengthened ... it was the esqualidos that really strengthened me and a lot of others as well when they took him away, that is when I got strengthened as a Chavista, because I am more a Chavista than a revolutionary, you see? I love that man. Imagine. So, no se metan (they better not screw him over) because we don't know how we will react $\ldots$ he has people behind him and loads of women behind him, we are loads of women, more women than men. Imagine this bunch of women against these esqualidos if they screw Chávez over...

Miriam was educated through the Frente Fransisco De Miranda, and had just graduated when I first met her in 2009. She had taken her courses and done her internships in Venezuela, as the program, previously in Cuba, was moved to Venezuela. She wished for and got a job in Fundacomunal as a promotor through a female friend who temporarily served as a director. In spite of her frustrations, she loved her job:

I like my job, I love my job, I like what I do ... I have worked Iselin, I've had a lot of jobs, I have worked in Pizza Hut, in Burger King, in private companies, in factories ... I have sold hotdogs, the only thing that I haven't done is work as a whore in a bar and that I will never do ... I have worked as a buhonera (selling stuff in the streets), I have cleaned toilets....

I studied as well, I took various courses, courses about everything, I studied accounting, administration and started to work in a tourism enterprise and that's when I started to work in administration, without university studies, but with my courses and the practical knowledge that I possessed, I worked there for 12 years, I changed over to the sales department, I did very well there. 
Afterwards I couldn't take it anymore with the political problems, with Chávez, I supported him and the boss was esqualido ... so I left and I don't want to work anymore in the private business, and well, God heard me and helped me with a job that I like...

\section{Knowing El Pueblo}

Miriam often felt that she had to fight to get support on the job and for the communal councils she was serving. The institutional structures of Fundacomunal were departmentalized and hierarchically organized, with limited flow of information between the director and the ground people such as herself. She felt that her knowledge of "what was happening on the ground" was not sufficiently respected or sufficiently taken into account when decisions were to be made. Moreover, the director of Miriam's office cultivated a circle of "loyal" people, while shutting out those who did not jalar bolas (suck up). As she found herself in the latter category, she felt that it was often difficult to have the ear of her superiors.

In her view, Fundacomunal was hampered by both political and institutional problems. On the one hand, Chávez's political directives of transferring power to el pueblo were not followed up on as they should. This was particularly worrisome because Fundacomunal was the frontline political institution mandated to empower the communal councils. However, instead of truly being a transformative entity making itself an effective tool for popular activism, it continued reproducing the vices of the "institutions" and "the bureaucracy" through institutional opaqueness. Added to this, the institutional legacy of Fundacomunal in terms of being hierarchically organized and still having staff originating from the Fourth Republic made it into an inefficient tool for co-operating and engaging effectively with poder popular (popular power). To Miriam, these were matters of grave concern, because the institution's shortcomings and inability to dar respuestas (give answers), made people hablando paja (talking bullshit) about both Chávez and the revolution.

\section{A Cadre for the Revolution}

Moreover, Miriam was utterly frustrated with many of her co-workers. Some of those working with her didn't care about their work: for them, it was just a way to cobrar (get paid), she alleged. They came to work in the morning, signed in, and then did nothing. As a consequence, communities that were assigned a promotor that didn't care about his or her work recieved poor or 
no support, which led to people losing faith in the government and in the revolution. She, on the other hand, viewed her job as a political task, which was what motivated her to continue her work in spite of her frustrations.

I am always telling the communities that this is thanks to el Presidente, these are the achievements of el Presidente, the missions, this is what he wishes for you, he wants you to study, he wants you to organize yourselves, and I explain all this about what the president wants, why the laws were made, why the Ley Habilitante was passed, all these things....

But I don't get too elaborate, because people don't like that, I talk to them in the colloquial way that we talk, you see? One has to talk to el pueblo in their own language-yes, sometimes it is necessary to discuss, but then you discuss with the people who are up for it ... but with el pueblo in an assembly, you cannot ... because people get bored, and instead of listening to you they start to yawn, the same thing has happened to me and I start to think of birds and stuff ... so you have to say things very pointedly...

For Miriam, the job as a promotor meant being a social worker, a politician, a pedagogue and, not least, an expert in conflict resolution:

You have to climb the cerros (shantytown hills) with them, trudge, assess people's necessities, be a humanist, see if they are carrying out the housing projects, listen to the señora, see if the communal councils are doing what they are supposed to do, find a way to try again, to act, to help, so that they don't get into trouble there.

As is clear from her accounts, Miriam sees herself as embodying the Bolivarian revolution, not the state. For her, the state is a corrupting force, evidenced by the lack of responsiveness that she saw around her. In spite of being part of el pueblo herself, she saw herself as a guide, instructing people and socializing them into becoming new citizens capable of taking on their new role in a new society. This was also Roberto's view, another promotor with Fundacomunal, also trained by the Frente Fransisco de Miranda. In an interview, I asked what he liked most about his job. This is what he answered:

The contact with el pueblo, because that is part of this conjuncture, it is the state ... through my work, taking it to el pueblo ... it is like one of Che's theories, that the cadre takes the grand decision of the state, makes them his and communicates them to el pueblo, trying to also make el pueblo assume it as theirs. So that is why this is a really beautiful job, you have direct contact with el pueblo, you see their realities, you make decisions, you are like an intermediary between el pueblo and the state. 
Of course, we have deficiencies in what comes back, in the dialectic you could say, but that is what we are working towards ... as part of the state one feels that one is contributing with solutions for el pueblo and that is the beautiful part, the direct contact with el pueblo, to make them the state, to transform them into state (volverlo estado, transformarlo en estado).

The promotores were the ones most frequently in contact with the communities. Basically, they were the state's "eyes and ears," with ample room for making their own personal judgments and choosing how to exercise their role. The promotores weren't distant "state officials." Rather, they knew well la gente (people) and how local dynamics were playing out in the communities. On a separate occasion, I chatted with Roberto about the problems in many of the communal councils, and the conflicts between different fractions and different interests. Most often there were conflicts between those who protected their own interests, and those who tried to stay true to the communitarian ideals that the communal councils represented. He said dryly that one always knows what la gente (people) are like. He could go to a community and immediately see "who is who" and what is going on: who is the cheat, who wants to work for the community, who is the idealist, who is the opportunist, who has a leadership role, who aspires to become a leader, who supports their work and who does not. In order to be a good promotor you had to know how to deal with la gente. As Miriam once stated in her matter-of-fact way: "Cuando veo los peos los mato rapidito" [when I see the problems surging I quell them immediately].

\section{O Inventamos O Erramos}

At least in the beginning, the signals from above were not to be too rigid about enforcing rules and regulations in communal council proceedings. The idea was that, if things became too formalized and bureaucratic, people in the communities would get de-motivated and lose interest. The impetus was rather to let both public institutions and communities learn along the way, and to let the thousands flowers blossom. At the same time, the organizational framework supporting the communal councils was still in the making, and Fundacomunal was struggling to adapt to the new legislation, caught up in internal issues and understaffed. Many of the promotores that were hired to work with the communal councils were uncertain about how to do their job. Indeed, there were no public servants that were entirely prepared for working with communal councils. 
After all, theirs was a completely new legal and organizational figure that had yet to be incorporated into the rest of the state bureaucracy.

Thus, Chávez's order was for institutions to learn to work with el poder popular, and he had el Frente Fransisco de Miranda assume responsibility for co-ordinating and managing the core institutions that would work with the communal councils. The idea "to learn as they went along" was epitomized by the phrase 0 inventamos o erramos (either we invent or we err). That was a phrase coined by Simón Rodriguez, Simón Bolívar's friend and teacher, talking about forming Gran Colombia. Chávez frequently held this phrase up as a guiding proverb, arguing that the bourgeois state had to be dismantled, and that a new state, el estado popular (the popular state) had to be built bit by bit. It could not be a pre-designed model, but rather an organic product of emerging social dynamics and the progressive accumulation of knowledge. Thus, just as the numerous missions had been launched "overnight" through the collective effort of state institutions and popular organization, communal councils would start functioning in the same manner.

\section{A Hybrid Space}

The next case study illustrates the modes of interaction between promotores and communities, and provides ethnographic details about how the processes of learning by trial and error were playing out "on the ground." As will emerge from this story, the social dynamics in each communitylas realidades (the realities) - as the promotores often said, were shaping community dynamics. Internal conflicts and alliances, and local notions of social space, structured the legal and organizational framework of the communal councils. The boundaries between the popular sectors and the state were difficult to discern, simply because the state effect (Mitchell 1999) had not yet been grinded into shape. Mobilization was taking place in a hybrid space between institutional and legal frameworks that were not yet concretized and much less enforced and systematized. "Popular" ways of doing things were flourishing in the absence of public officials that knew how to enforce state policy or had internalized their role and agency as representatives of the state. This produced a hybrid space, I will argue, whereby the communities tentatively tried to "become" communal councils, yet steeped in complex local socialities shaping those processes. At the same time, public officials were also trying to learn "how to become the state" while at the same time upholding the principle of promoting el poder popular. 


\section{O Inventamos O Erramos in Practice}

April 2009: it was 8 am, early on a Sunday. I met Miriam down by the Agua Salud metro station in 23 de Enero. Together with Miche, a colleague of hers who normally worked in another parish, we went to do an inspection of the work of some of the communal councils in the area. The inspection had been scheduled because Chávez had recently instructed Fundacomunal to evaluate how the communal councils were progressing before he authorized the injection of new funds for a new round of projects. I greeted Miriam and Miche, and we jumped on a camioneta that took us to a community in the eastern part of 23 de Enero. When we got there, Miriam walked us over to the house of the vocera (spokesperson) in the communal bank. She was a middle-aged, short woman, and originally Colombian. Her daughter, as well as some of the other voceros from the finance committee, was also present.

Miche and Miriam started talking in a friendly but inquiring manner about how things had been going with the housing and rehabilitation project. It soon turned out that there had been some irregularities. The communal council in place when we visited that day was not the original communal council. The original council had split into two branches: one above the road and one below the road. According to the woman, they had received technical assistance from the municipality in doing so. Miche and Miriam made it clear that this was against the law. It was only Fundacomunal that could supervise and approve the constitution of communal councils. Who the representative from the municipality was and what his or her real involvement might have been was never clarified.

Additionally, the communal council could not present bills for its purchase of construction materials as checks were made out to individuals. This was a clear breach of the duty to rendir cuentas (present accounts) to the community and to Fundacomunal. No social comptrollership committee had been monitoring how the projects were proceeding and how the money was being spent. The communal council had hired an external co-operative to do the work. The co-operative had been recommended to them by the Ministry of Health that had previously hired them to set up a health module in the sector. However, the money dried up before the projects were finished and a lot of the work was left incomplete. Some of the money had also been used on a medical emergency in the community and on the purchase of some take-away lunches. The women were in obvious distress over this and Miche and Miriam were not too hard on them, saying that this was not an irregularity in itself as long as it was approved 
by a community assembly. The problem was that they had not convoked such an assembly.

The original project was to restore 27 houses and substitute 5 , for a total amount of 870,000 Bs.F. Allegedly, the vocera had received part of the funds $(15,000 \mathrm{Bs} . \mathrm{F})$ to remodel her own house. She was in fact showing us her house, which was obviously in the midst of a renovation. The discussion was going back and forth, and the lady was explaining as best she could. Both Miriam and Miche were laid-back and non-confrontational, though I could tell that they were subtly trying to understand what had actually happened. Miche was more concerned with recommending that they confront the co-operative that had abandoned the work than with confronting the woman from the communal bank. He strongly recommended that they organize a construction co-operative themselves, within the community, consistent with the government's focus on desarrollo endogeno (endogenous development), so the money could be returned to the community in the form of local labor.

After more discussions, the women accompanied us to a neighboring house. While walking, Miriam pointed out to me that the woman seemed nervous. She and Miche commented that something obviously had gone wrong there; they didn't even represent a legally constituted communal council. However, they couldn't only blame the communal councils; Fundacomunal was also to blame as it hadn't done sufficient technical follow-up, Miche said. Moreover, it seemed as if Fundacomunal hadn't given them any technical assistance in developing the project in the first place, and that was one of the reasons the budget didn't cover the work once the co-operative started the construction process. The co-operative should have detected this, Miche said, but he wasn't sure of what their role in this mess had actually been.

The next house we entered was a typical Venezuelan family barrio house on three levels, where extended family and in-laws lived together. The family had originally received money to renovate the second floor. However, in the course of the process, they had decided to use parts of the money on the third floor of the house, where the niece lived. We climbed up the narrow stairs to the third floor. The head of the family was enthusiastically trying to explain what he had done and how he had done most of the work himself in order to make the money last longer. Miche had a very diplomatic attitude while he made clear that, while he congratulated him with the work done, it was illegal to use the allocated money for something other than what it was originally intended for. Decisions on how to 
employ the money are made by a community assembly and recorded on a legal document. However, he underscored that he wasn't there as an enemy. "As I am institution, and thus part of the state, I come to find out what was done with the money."

When we finally left the house, we moved on to the casa de alimentación (communal kitchen). They had received money to upgrade the kitchen through another project. A poster of Chávez hung on the wall, over a large stack of bags of rice.

We were served coffee, and stood there for a while talking with the women in the kitchen and in the communal bank. Miche underlined to

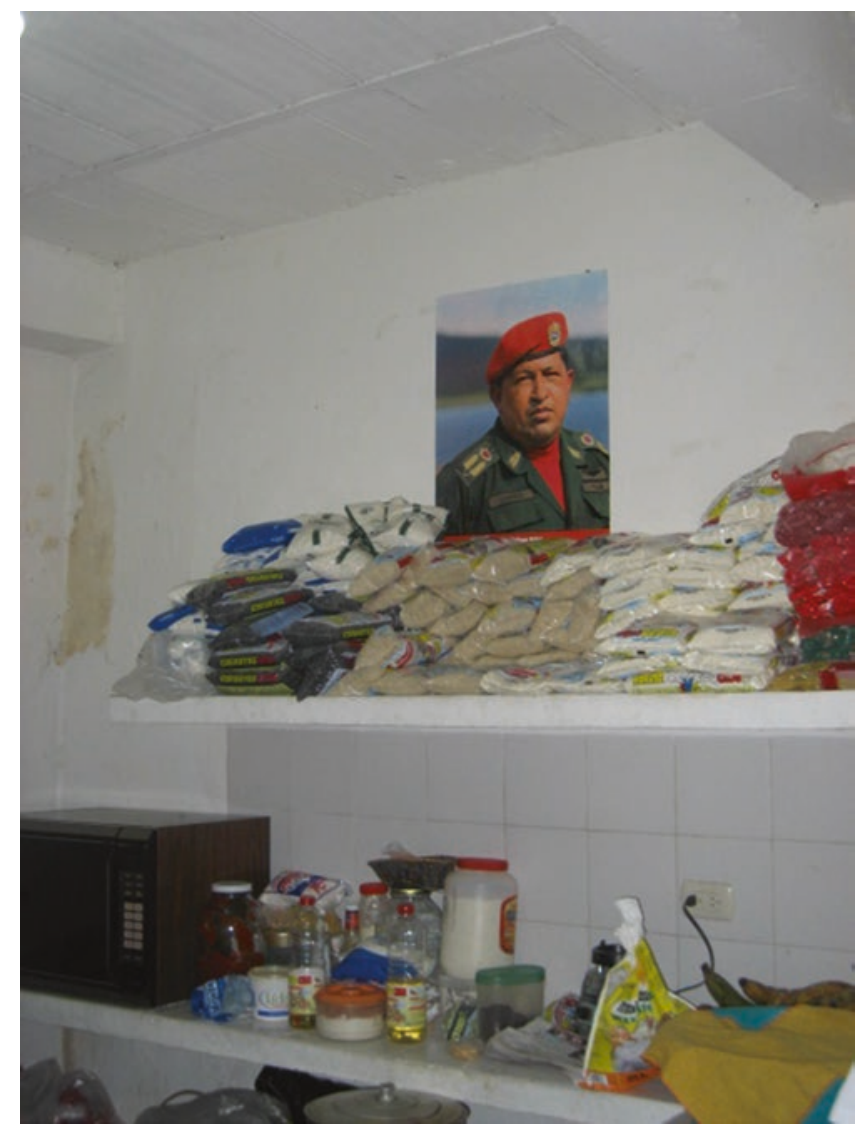

Photo 7.1 A Casa de Alimentación (soup kitchen) in 23 de Enero. Photo by the author 
the community members that they were not there to create problems for the community, rather to find solutions. The problem, as he saw it, was that there seemed to be a lack of unity in the community, which was why the communal council had split in two in the first place. Miriam stated that they should have started with collective projects in communal areas, such as sidewalks or parks, before taking on housing projects. "It is very difficult to carry through such a large housing project si no hay communidad (if there isn't [a sense of] community)," she said, "and we don't want people to be like in the east (in the middle and upper class areas) where they eat inside the house and don't know their neighbors."

As we continued walking, Miche, Miriam and I fell a bit behind the others. Miche and Miriam agreed that the problem was apathy-if the community doesn't get involved, there is space for personal interests to take over the project. Miche said that he understood that the woman in the communal bank had been under a lot of pressure by others in the community. "When they see that the money is being channeled down (se bajan los recursos) they want more and more." "And the institutions must be selfcritical on this point," he said, "because if the community is left without proper guidance, it becomes difficult for the spokespersons to manage the issues right and hence withstand the pressure."

We continued our walk for a few more hours. Some of the families we visited were reasonably content, while others were outraged with both the communal council and the co-operative. One man exclaimed: "It is all a big trap." He had been forced to pay a large part of his new roof himself, as the work was abandoned before it was finished.

After the tour, Miche, Miriam and I went over to a nearby health station where a larger community meeting was scheduled to take place later that evening. We sat down, tired after a long day in the baking sun. Miriam and Miche spoke among themselves about what they thought had happened. Obviously, someone had cut a deal with someone, and someone had been left out, and the woman was obviously nervous because she knew that they couldn't present the bills and they knew that things hadn't taken place according to procedures. "But I don't know if they gave in for pressure from the community and the co-operative, or if they opted for anarchy," Miche said. The problem was also that there had never been any social comptrollership in the community. All communal councils are obliged to have a committee for social controllership that checks that the money is spent according to the budget. However, Miche didn't seem particularly upset over the day's events. Rather, he was quite pragmatic about it: "It isn't corruption as such, but rather misuse of funds. They are 
gente humilde (humble people)." And, he underlined, they hadn't been properly followed up on by the institutions, which made it very difficult for them to carry out the project according to established procedures. The experience with the communal councils was still very new, and the communities were unaccustomed to managing such amounts of money, he asserted.

\section{Exercising Popular Power}

The following day I met up with Miche and Miriam again in the morning in order to do an inspection in another communal council-this time in Antimano, one of the poorest barrios in Caracas. Because of this, the community was considered a high-priority area, ${ }^{2}$ and had a lot of projects approved. We jumped on the metro from Agua Salud to El Capitolio before we changed to another metro line and reached the metro station Antimano. The barrio of Antimano is an impressive sight: the facades were painted a few years back as part of one of the first government urban housing projects. The whole hillside looks like a painter's palette, each facade painted in different colors.

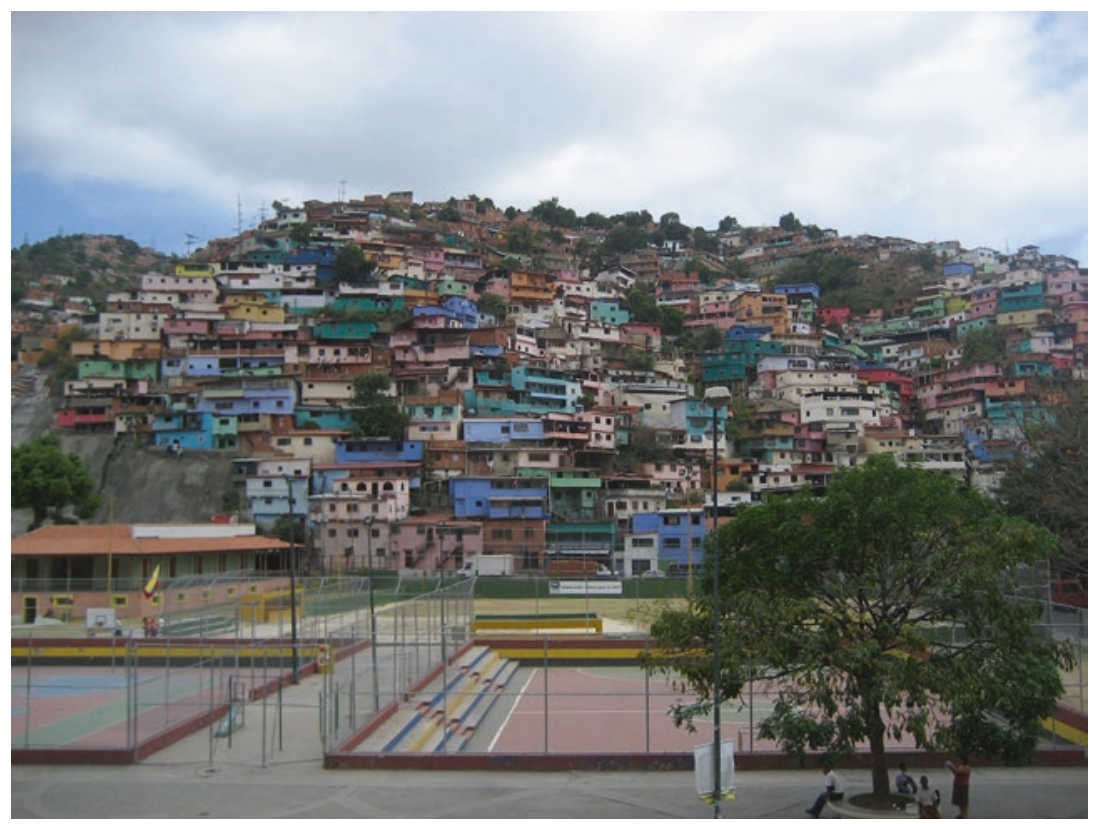

Photo 7.2 The barrio of Antímano. Photo by the author 
It was still early in the morning and none of us had eaten breakfast yet, so we sat down in an arepa joint outside the metro station waiting for the community leader that would pick us up. The most common morning snacks for Venezuelans are empanadas, deep fried flour pastries in the shape of a half-moon. The most common fillings for empanadas are cheese, or seasoned shredded beef, chicken, fish or minced meat. The treat is typically accompanied by soft drinks of freshly squeezed juice. It is really tasty, but it also explains the high obesity rate and the high sales rate of seltzer in Venezuela.

We had just finished eating when the community leader Pedro arrived. He was a friendly man in his 50s sporting a cowboy hat, with an air of natural authority. He explained that their communal council was a semirural communal council, located on the fringes of the barrio in a fertile area. That meant that their council did not include 200 to 400 families as councils of high-density urban areas did. Theirs was limited to 40 to 80 houses.

In addition to the housing projects that we were there to inspect, they had managed to make a sports center, to install a PDVAL (government sponsored mini-market) and to restore the stairways into the community, he told us. Their long-term goal was to establish a commune together with four other communal councils in the area. However, the time was not right, he said, because the other communal councils hadn't started functioning properly yet.

We approached the fringes of Antimano, where their barrio was, on a hill surrounded by trees, vegetation and some cleared land. His family's house was located in the upper part of the community, an impressive and large building with an amazing view over the whole valley. We were taken to the office from which the communal council was operating, a little space at the back of his house. They had made several large posters of all the different project and community events, complete with photos and drawings. Here were posters of the staircase project, the Dia de los Niños (Children's Day) party and the housing project event. The paperwork was organized in neatly marked paper files, stacked on a shelf, and a computer was sitting on a desk.

Miche and Miriam asked about who had carried out the housing project. "We chose the solution that suited the community best," Pedro said. Through assembly meetings the community had simply decided to divide the money equally between all the households. They had 34 carpenters and 31 construction workers living in their community, he informed. So instead of hiring an outside company or co-operative, they had done the 
work. Miriam asked if they had gotten help from an engineer, but Pedro responded that, no, they knew how to resolve their problems and had solved everything themselves. Now all the projects were finished, except for one house for which they had run out of money. In the next couple of days they would arrange a memoria y cuenta (report and account) in a community assembly where each household would present a report on how money was spent.

When Miriam had finished looking over the papers, we started the inspection, going from house to house. Some houses were in very poor condition and had been completely rebuilt, while others were in fairly good condition and had seen more "luxurious" upgrades, such as ceramic tile floors. People were visibly satisfied and explained to us in detail the work they had done. Afterward, we were escorted by Pedro to the small community super-market, PDVAL, which also functioned as a communal kitchen. There, we were served dinner by some of the women in the community. Afterward we sat out on the patio while Miriam filled out the paperwork with Pedro before he drove us back to the metro station.

A couple of days later, we returned for the memoria y cuenta event, which was on the patio outside Pedro's house. A large circle of chairs was set up under the shade of some trees. Pedro told Miche and Miriam that they had gone from house to house and informed people about the meeting, collecting their signatures, which confirmed they had received the message. One by one, they explained to the group what they had done with their house. One woman started to cry out of gratefulness and happiness. She was so relieved over finally having a vivienda digna (dignified home). One man directed his gratitude to "God and to el Comandante." All in all, 36 homes had benefited from the project.

When everyone had explained what they had done with the funds, Miche made a small speech. He said that he was very happy with the work of this communal council, even if they had distributed the money equally among all households instead of distributing according to a community census over who were in most need. Nevertheless, he viewed their work as very positive, and said it was a true expression of poder popular. He maintained that in many communal councils, people were trying to implement projects by the book, and instead ended up fighting. He encouraged the community to collect some money in order to repair one of the stairs he thought was in dire need of repair, as the elderly woman who lived there had problems climbing up and down the staircase to get to her house. 
He thought they were ready to launch some socio-economic projects. "Recently the communal councils in Caracas have just been concerned with bricks, cement and sand, and we all know that it is necessary, but we also know that there are a lot of other needs here as well, like culture and socio-productive activity." Pedro said that they had a seminar scheduled for the next day about agricultural production and that they had already received credits from Fondemi ${ }^{3}$ for different socio-productive activities like the production of sweets and pastry, a sowing project and painting and carpentry businesses. The meeting was dismissed shortly thereafter and Pedro drove us back to the metro station. Both Miche and Miriam were in a very good mood on the ride home. They expressed great satisfaction over how the community had been able to ejecer poder popular (exercise popular power), organizing themselves in a way that benefited the common good.

\section{TeXtures of Relations}

From the ethnographic accounts above, we can discern the complex dynamics surrounding the communal councils, as well as the texture of relations (Gupta 1995:215, cited in Sharma and Gupta 2001) between the realm of the state, represented by the promotores, and the realm of the popular sectors.

As we have previously discussed, social and spatial configurations in a neighborhood shape people's knowledge of each other, the degree of social trust, the degree of social cohesion and their assessments of common needs and priorities. To outsiders, the barrio seems like a chaotic labyrinth with few apparent borders and boundaries. From the inside, people have a keen awareness of what is on the inside, on the edges and on the outside of "their community"-even if it is not inscribed on a map. Consequently, you also have a sense of who are "your" people, and who are "the others"- those in the barrio over there, those in the bloques down there, those who use the stairways over there, those who have just set up a shack settlement over there. All these factors contribute to the particular dynamic surrounding the unfolding of a communal council.

As we will discuss below, the importance of anchoring communal councils in people's own socio-spatial identities were not at all lost at lawmakers, and it was also of great importance to popular sector activists. However, at times, communal councils were formed that didn't necessarily conform to "natural boundaries." As in the case with the first communal council that I 
visited with Miriam and Miche, this at times lead to splits and the forming of new communal councils. Both of them immediately captured that there was a low degree of social identification and cohesion in the community, and that this was an underlying partial cause for the irregularities and lack of transparency in the communal councils' proceedings. Consequently, Miriam's advice to the community was that they should have started with collective projects bringing them together in a joint cause, rather than housing projects benefiting individual households.

Another key issue was the existence of leadership figures in the community. In the first communal council, leadership roles in the communal council were assumed by a group of people that apparently had no trajectory or experience as local leadership figures in the past. Consequently, Miche and Miriam speculated if they had been subjected to pressure from other community members as well as by external actors, and directed their critique toward the institutions for not providing enough support and guidance.

In the other communal council, Pedro came off as the undisputed local leadership figure in the barrio. Both his aura, attitude and property (his house was much nicer than the rest, and he also had quite a bit of land attached to it) indicated that he was a resourceful person. Moreover, the community itself, as a semi-rural community with quite defined edges, contributed to enhanced mutual social identification. Miriam and Miche captured and understood these dynamics, and even if they at one occasion called Pedro the local "patron," they acknowledged that he had used his power to (as far as they could gather from our two visits) bring the community together in a transparent and relatively friction-free process.

In short, Miriam and Miche viewed the unfolding of the communal councils both through the lens of "the local realities," at the same time as they assessed how the communal councils were faring according to the directives of the state. However, given that the order from above was to let the thousand flowers blossom, they adapted a pragmatic position, estimating success in terms of social achievements for the community rather than strict adherence to the legal framework. For them, as well as for many state legislators, the communal councils were not only about using state money to execute local development projects. They were also means to a superior end: to promote participation and social cohesion in the communities in order to strengthen poder popular. These experiences were building blocks for the communal state that eventually was to replace the bourgeois state (see Ciccariello-Maher 2016). As a member of the national assembly, 
who had been central in developing the law for the communal councils commented:

We define the communal councils as a broad popular organization as defined by article 2 in the law [for the communal councils] .... They should be a space for the articulation between citizens, between popular movements, between social movements and all the expression for popular power that exist within a geographical area, which we have called a geographical communitarian space (espacio geográfico communitario) where the communal council is seated ... this is a strategical intention (linea estratégica) linked to the development and profoundization of direct democracy, of participatory democracy, of popular democracy.

From these formulations, we can discern how the ideological and discursive framing of the communal councils from "the heights of power" put emphasis on the exercise of popular agency. Consequently, as agents of the state as well as popular subjects, Miriam and Miche viewed themselves not as Weberian disinterested public officials, but as cadres whose job it was to guide and empower people to assume a new form of citizenship in alignment with the idea of a radical participatory democracy in the making. It was a delicate balance, for they understood all too well that the communal councils lend themselves to conflicts and not-so-noble actions and maneuverings. Thus, their role was to try to steer things in the right direction through maneuvering in local landscapes as well as providing critical feedback to the state institutions.

\section{Development From Below}

In many respects, the knowledge production surrounding the communal councils was in alignment with insights provided by critical development scholars and analysts (e.g., Pigg 1996; Cooke and Kothari 2001; McNeish 2001). Development projects can very uneasily be mandated from above in a pre-designed manner. Rather, projects need to be firmly rooted in the social realities, local populations and specific needs in the locality which they are intended to benefit.

Some scholars have been highly critical of the communal councils, arguing that they promoted clientelism, co-optation and patronage (Machado 2009; Alvarez and García-Guadilla 2011; López 2011). While this is certainly one aspect of it, it is also important to recognize not only the 
social and human gains that they generated, but also the effects that these experiences had in terms of advancing local organizational skills and capacities. In those communities where communal councils did work out well, it often generated both community cohesion and significant welfare improvements. Innumerable people had their housing standard upgraded, or were relocated to new houses in the cases where they were living in gravely substandard- or dangerous housing. (Many barrio houses are built in landslide-prone areas, and it is not uncommon that people lose their lives when their houses collapse.) To popular sector households, which might spend years and decades slowly improving their housing standards, the ability to add an extra room to their home, to install a bathroom with an actual door, to have a cement floor instead of a dirt floor, to put up a roof that did not leak when it rained, constituted an enormous enhancement of their quality of life, and not least for their sense of dignity. Many communal councils also prioritized upgrading local infrastructure such as roads, passages, stairways, parks and sewage systems, as well as local sports facilities and other collective welfare improvements.

Moreover, from a scholarly perspective, it is paramount to analyze their evolvement within the real-life context within which they were unfolding (see also Ellner 2009; Irazábal and Foley 2010). Promoting "development" and popular empowerment is never a straightforward process, not least in contexts as socially and materially complex as shantytown communities historically shaped by entrenched socio-economic inequalities and socio-cultural marginalization (e.g., see Willson 2007). The development of each communal council-for better or worse-was conditioned by local modes of sociality, local spatial configurations, localized interpretations of needs, existing social resources as well as the support they received from state institutions. Moreover, the features characterizing different communities were not "static" characteristics. Over the years, I observed that different communities went through different phases and stages as the communities gradually accumulated collective knowledge about the legal, bureaucratic and administrative aspects of managing the communal councils. Some managed to resolve conflicts, while others entered into new ones. The communal councils constituted a steep learning curve, whereby "local development scapes," to paraphrase Appadurai (1990) were gradually fostered as social relations and local needs were increasingly reconceptualized through the framework of the communal councils.

The promotores, in time, also became more skilled in their work; though, here too, there were differences among them. There was a quite 
high turnover rate among the promotores, and not all of them were apt at working with popular sector communities. I also occasionally heard rumors that some of them abused their position in various manners, for example, through charging a "cut" from approved grants, or by undue meddling in local struggles for power. At the same time, other promotores, like Miriam, became very skilled in mediating local conflicts and trying to steer the communities toward doing things "by the book" and for the common good. Many promotores also became deft at nudging the right state offices and officials in order to help "their" communal councils.

\section{Schools for Popular Power}

In the course of the first few years, it became evident, both to the lawmakers and the institutions in charge of supporting and financing them, that there was a need to strengthen the communal councils' capacity to concretize and develop projects. Moreover, people asked for more support and guidance from the institutions as project development generated a lot of confusion and problems. For that purpose, workshops were organized in the communities, part of what were called escuelas de poder popular (schools for popular power), oriented toward providing both ideological, political and technical education to the communal councils through "educational cycles" organized across the country.

On one occasion, I attended a workshop in 23 de Enero, called taller de formulación de proyectos (workshop for formulating projects). The meeting was led by Juan Roberto, a promotor from Fundacomunal. There were 14 people present from different communal councils; all but one were women. The goal was to help people concretize their problems, and translate them into a project that could be submitted to state institutions for financing. The workshop was divided in two parts; the first part was a theoretical explanation of methodology, and the second one was a session on the application of the methodology to a project's development. Juan Roberto explained that people often confused "themes" with problems, which hindered their ability to find solutions. For example, people would say that "garbage" or "safety" were their problem. However, Juan Roberto stated, these were not problems, these were themes that had to be concretized into specific projects. A "problem" could be, for instance, the lack of a sports field in the local community, which could then be developed into a project step-by-step. He shared some points (Table 7.1), which could be used to facilitate this process. The points consisted of: 
Table 7.1 Points from workshop discussions about how to analyse and elaborate a community project. The parish of 23 de Enero, Caracas, February 2010

- Definition of the problem (the location of the problem, who is affected by it and for how long people have been affected, i.e., the lack of a sports field in the community la Camboya affecting children and adolescents, and a total of 200 families for the past 10 years)

- The name of the project (reflecting exactly on what the project is about, i.e., sewing elegant dresses)

- Amount of money required to carry out the project

- How long it will take to carry out the project

- Where the project will be carried out, and by which communal council

- Description of the problem

- Cause(s) of the problem

- Why it is worthwhile to implement the project, i.e., what will be gained from it

- What is the motivation for carrying out the project

- What will the concrete result be once the project is finished

- Who will participate in the project, who is responsible

- Development of a step-by-step plan for how the project will be carried out, including follow-up and control

Throughout the workshop, Juan Roberto used concrete examples of common communal council activities: building a sports field, setting up a local project for sewing women's clothes, or building a new pipe system. People were eagerly participating by sharing their points of view, contributing the experiences from their own communities. Juan Roberto managed to engage people without seeming patronizing, and he demonstrated intimate knowledge of the nitty-gritty details of community development planning, such as the diameter of the tubes needed to upgrade sewage systems, and the challenges of sending toddlers to kindergartens on the congested camionetas traversing the barrios in the morning. In fact, Juan Roberto lived in Casalta 3, the same area I was living in at the time, and was therefore very familiar with the barrio reality.

\section{Metis and Popular Power}

In the example above, Juan Roberto has attempted to concretize formal procedures for project development through drawing on people's skills and knowledges about their own social and material realities. The Bolivarian discourse put much stress on the inherent differences between the knowledge of the state and popular knowledge. Popular knowledge 
was understood as the knowledge that people had accumulated through their real-life experiences in their particular (challenging) environment, or what was sometimes referred to as los saberes del pueblo (the peoples' knowledges). In fact, the way popular knowledge was conceptualized came very close to Scott's (1999) concept of metis: "a wide array of practical skills and acquired intelligence in responding to a constantly changing natural and human environment" (Sunstein 1998). Scott maintained that communities that were marginal to market and states had to acquire a high degree of metis out of necessity, "as they have to rely disproportionally on the knowledge and materials at hand" (Scott 1999:335).

People often referred to popular knowledge as an open referent, as something that constituted a wide array of skills, knowledges and life experiences. It referred to the constant creativity and improvisations needed in order to construct your barrio house with scarce resources. It referred to people's accumulated and collective knowledge about soil conditions and local topography, about the improvised constructions of sewage systems and electricity grids, about the intricacies of buildings and constructions that were built and intertwined onto and into each other, within any engineer telling them when the construction had reached its maximum bearing capacity. It referred to the creativity of making ends meet, and about their capacity to organically organize in the face of collective needs and crisis. It was a form of knowledge rooted in a deep knowledge about their social environment, in the genealogy of the barrio and sector they were living in, in the myths, memories, and stories underpinning local social identities.

In short, popular knowledge was drawn from the dense experiences of living life on the margins of society and the official economy, to live in a culture of urgency (Pedrazzini and Sanchez 1992) that often produced hardships, but also enormous creativity and resilience. It constituted a different form of knowledge than the life experiences of the middle- and upper classes, cushioned by their socio-economic resources, of formal spheres of society, and of the techniques, procedures and rationalities of the state.

The latter aspect, the contrast between the knowledges of the state and popular knowledges, was constantly stressed in Bolivarian discourse. The state's way of doing things was conceptualized as its slow institutionalized procedures, its emphasis on formalities, its faulty capacity to act "in the moment" and improvise, and above all as its lack of knowledge about local realities. These contrasts repeatedly emerged as an issue in interactions 
between the popular sector and state representatives as a way of making explicit that there were two different modes of action, reasoning and making use of knowledge at play.

\section{Capturing Local Realities}

However, the importance of drawing on local knowledge and resources was not only emphasized by the popular sectors. It was also highlighted in the formal procedures of the communal council as well as the ideological discourse surrounding them. In order to form a communal council, the community had to elaborate a written overview of the social genealogy and cultural characteristic of that area. The explicit purpose was that through capturing popular history and making people's common identities and histories explicit, the communal identity-a key factor for making the communal council work-would be strengthened. Moreover, a central task for a newly constituted communal council was to elaborate what was called a diagnostico social (social diagnostic) and a diagnostic communitario (community diagnostic). This implied making a survey of population - their demographic profile, how many people resided in each house and under what conditions, what special needs they might have (medical or otherwise), the community's housing conditions, and so on. It also implied making an overview of the infrastructural characteristic of the community and the availability of services and recreational areas-or lack thereof. They also recorded available human resources in the community, such as laborers and professionals that could participate in developing or executing projects. In order to elaborate the diagnostic, the voceros and voceras of the communal council walked from door to door-preferably on Saturday afternoons or Sundays when people often are at home. Consequently, the diagnostic formed the basis for developing projects according to the community's most pressing needs and joint priorities.

\section{Negotiating Power}

Conflicts and negotiations between the popular sector activists and state officials over how to ground community activism "in the local" played out in a variety of manners. It could be the extent to which local activists were involved in the development and planning of project initiated by the municipality, and who would be employed in the project. It could be over where meetings would take place and when: in a public office during office 
hours (which created a lot of problems for people) or in the barrio at a time when people were off work. It could be over the paper trail necessary for forming communal councils and developing projects, and for delays in getting answers from the institutions, which often caused that the initial community mobilization waned and the project lost its momentum. These conflicts and negotiations were frequently framed by popular activists as fundamental ideological and political problems. In their opinion, the state had not been sufficiently conquered by popular power, and was reluctant to cede space and change procedures accommodating the strengthening of popular power.

For example, in May 2009 I was present at a two-day workshop about the proposal for a new law that would govern the organization of the communes (Ley Orgánica de las Comunas). Consistently with the inventamos o erramos approach, Chávez had suggested that a commune had to be constructed and invented along the way. To that end, several pilot communes had already been set up in different parishes of Caracas before their legal framework had been developed. At the workshop, there was a lot of meta-critique of the revolutionary process. One of the most frequent complaints was that popular power had not gained sufficient space and force. The structures of the state did not allow for people to assume power, and the state did not cede power to people. "The resistance to the poder constituyente (constituent power) has to die," one man said as a metaphor. Another man criticized the Law for the Communal Councils (which was also debated at the time), arguing that it contained several elements that had nothing to do with their everyday life and that the law had to be submitted to popular discussion again (which happened later that year). Another man suggested that people should work with the National Assembly through the Comites de Legislación Popular (Committees for Popular Legislation) and that with time the communes should develop instituciones de gobierno de poder popular (institutions for the government of popular power) that would take over areas of responsibility from contemporary public institutions. ${ }^{4}$

The discursive content of these discussions reflect the deeper ideological debates over what popular power entailed, and the political obstacles toward obtaining it. Debates such as these were quite common in political and public meetings, though primarily taking place among popular intellectuals, political figures and ideologically oriented activists.

However, on a day-to-day basis, numerous less explicit political struggles were also taking place. Many of the participants in the communal 
councils were more concerned with concrete obstacles to their organizational efforts than with ideological debates. The main points of contention were the institutions' lack of flexibility and unwillingness to adapt to their needs. The ways in which the state functionaries, or political figures, dealt with popular complaints varied. Often, public functionaries would be practical and pragmatic; they would listen to community complaints and, as in Miriam's case above, suggest ways of dealing with them. Indeed, more often than not, there were constructive dialogues and respectful interaction between state representatives and community activists, not least when they shared a common socio-economic background and ideological engagement with the Bolivarian process, which was often the case. However, sometimes, public functionaries would try to divert attention away from the complaints that were raised. This would often provoke the anger of the community activists, who were wary of "condescending" and "patronizing" attitudes.

\section{The Meeting that Got Off Track}

Below is an example of such an encounter, at a meeting in 2009 attended by two public officials and several members of communal councils in 23 de Enero. The meeting took place in a community health station in 23 de Enero. I was invited to the meeting by Ricardo, a promotor in Fondemi, to whom I had been introduced at a community meeting the night before. Ricardo was from 23 de Enero at the same time as he served as the promotor for its parish.

Fondemi was another state institution dedicated to channeling funds to projects elaborated by communal councils. Whereas Fundacomunal was financing projects related to housing and infrastructure, Fondemi solely focused on proyectos socio-economicos (socio-economic projects). Only projects developed within the vision of communal, endogenous development could formally be considered for funding. Those involved in the project had to establish themselves as a social or communal co-operative, and parts of the income had to be circulated back into the community in the form of seed money for new economic initiatives or as a social emergency fund (e.g., if someone were in acute need for money for a health emergency or a funeral or if their house collapsed). Furthermore, the projects had to be elaborated in accordance with identified local needs emerging from the diagnóstico communitiario (community diagnostics). For example, if the community did not have a bakery nearby, Fondemi 
could finance the establishment of a co-operative-based bakery. Similarly, the institution could finance the establishment of local manufacturingmany of them supplying school uniforms to the local Bolivarian schools. However, one of the criteria for having a project approved was the use of primary materials. For that reason, Fondemi did not finance business proposals for hairdressers, Internet cafés or DVD rentals. However, Ricardo confided to me that there was flexibility as to which projects were actually approved, in order not to crush the communities' initiatives and energy.

The meeting at 10 am was aimed at informing the spokespeople from the communal banks about how they could work with Fondemi. Chávez had recently announced that the creation of communes was "high priority," and for that purpose, Centros de Formación Socialista (Centers for Socialist Formation) were about to be established in the barrios. These centers were to be educational and informational centers that would function as a meeting place for different community social groups and different state institutions.

Before the meeting started, Ricardo said that he expected 80 people to attend. Only 12 joined. We were sitting outside, on the upper floor of the local health station, which was not open at that hour of the day. A tall slender man in his late thirties, another promotor from Fondemi, was hosting the meeting. A black, intense woman around the same age, who lived in the barrio El Junquito, in the outskirts of eastern Caracas, was also attending. She started the meeting by talking about El Salvador, where Mauricio Funes had won the presidential elections for the left-wing Farabundo Martí National Liberation Front (FMNL) just three days earlier. She was probably trying to incite the revolutionary spirit of those present and put their "domestic revolution" in a larger context. Her attempt failed, triggering a slightly skeptical attitude in the audience. She held a short passionate speech about how El Salvador constituted another front in the left-wing wave that was sweeping the continent, and how they had now woken up from their enslavement. She then proposed that the participants offer their views on the issue, but people were just staring, slightly confused and amused by her. A few people eventually spoke about the recent events in El Salvador, but her speech did evidently not generate the enthusiasm she was hoping for.

It soon became clear that it was the practical day-to-day challenges that the voceros wanted to discuss. One member said that he had tried to develop a project that involved Fondemi, but Fondemi demanded that all five voceros in the communal councils attend a five-day seminar, when 
it was obvious, he said, that people could not do that, as they needed to work. He finished by alluding to Chávez's call for everyone to come out in the streets and work after the victory on February 15. "But people have been in the streets all the time since the process started. It is the institutions that have remained inside the walls!"

Another man said that his communal council was also told to attend seminars by Fondemi but that they could not go either because of work. "They are not responding to the needs of el pueblo, but to the needs of Fondemi," he stated firmly. The next speaker said that he could only speak from personal experience and that he had just started working in the communal councils, but so far he felt that they had received satisfactory responses from the institutions. The next speaker said that they all had to exercise control over the institutions and that the institutions needed to have a flexible time schedule that suited people, not the bureaucracy. If not, people would become demotivated. In their case, they had started to work on a project for one of the bloques in their community, up in the El Mirador sector. The bloques were falling apart, and they had taken photos and had received visits from people from the institution. As there had not been subsequent follow-up from the state, the initial interest waned and people lost their enthusiasm.

The woman from Fondemi then said that, certainly, within the institutions there were people who didn't work as they should and who bacen trampas (play tricks); "but we, as revolutionaries are above this," she said. Revolutionaries do not have their own lives, she continued. She used her own sacrifice for the revolution as an example, how she was working day and night, coming home late to her children. She acknowledged, however, that many people were working and could not go to all the meetings all the time. What the communities needed to understand was that the communal councils represented la nueva institucionalidad (new institutionalism), and that the communal councils were not only composed by the voceros, but by the whole community. "So if the voceros cannot come, another member from the community should go instead," she stated. She used their meeting as an example and said that those convoked were the heads of the communal bank, and they were there not only for themselves, but also for the whole community. They needed to go back and inform everyone about what had taken place at the meeting. "We are all a part of the process and we all need to contribute to developing all of us," she said.

She continued talking about how the process of the communal councils was a "trying, failing and learning process," and that it was easy to blame the institutions when something went wrong. But the communities also 
had to look at what they did. "Take the problem with money that 'disappears.' Millions have been bajados (channeled down) to the communities for infrastructure projects. Millions of gotas de petroleo (drops of oil), but no one in the communities has so far been jailed for corruption."

After a bit of back and forth over this topic, she announced that it was time to get instructed on how to develop the community projects. The semana de formación (education week) started in April, and they would accommodate people's schedules so everyone could attend. One man asked if they would be getting money for transport to and from the meeting, and was told that they would not. "Chávez says that as a revolutionary one has to work 23 hours a day, and as a revolutionary one has to move around." Again, the woman from Fondemi referred to herself and to how she the other day got home at $11 \mathrm{pm}$, to El Junquito where she lived. "I was worried about the kids, it was late and it was dangerous." One man responded in a slightly sarcastic tone: "No one doubts your compromise, negrita." 6

In my fieldnotes from the meeting, I noted that people at the meeting were becoming warier toward the woman from Fondemi as they were trying to raise real issues, while she was trying to focus on "ideological tutoring." At the time I was puzzled by the fact that the promotor leading the meeting was unusually "out of sync" with the people present, especially since she was a lower-level public functionary from a barrio. I was later told by another worker in Fundacomunal that promotores had recently been instructed by their superiors to hold an inspirational and educational speech before meetings in order to foment consciousness about the larger context of their day-to-day struggle, which explained why the promotor seemed out of touch from the very beginning in this particular meeting.

Several researchers have noted the high level of politicization of the communal councils (e.g., Álvarez and García-Guadilla 2011), but as this episode illustrates, the "recipients" of ideological touting are hardly passive subjects. If people didn't like the content of the meeting, whether because of ideological touting or for other reasons, they would deploy a range of "strategies of resistance" such as being sarcastic, leaving, talking among themselves, talking back, quarrelling or playing with their mobile phones, amounting to local variants of Weapons of the Weak (Scott 1985). Moreover, the push toward picking up on ideological subject often came from popular sector activists themselves, who used it as a discursive tool to criticize the state institutions' deficiencies and unwillingness to assume a revolutionary agenda. 


\section{Negotiating Hierarchy}

We have previously referred to the popular sector's contestation of the cultural hegemony and politics of the state. A key aspect of this struggle was to challenge class distinctions inscribed in the hierarchy among grassroots activists, barrio residents and state officials. As previously noted, the social composition of the Venezuelan state and political class has undergone a shift, and there are now more people from popular- and leftist radical backgrounds occupying these positions. At one level, this changed the form of interaction between people and the state because of increased socio-economic and political proximity, at the same time as the inherent hierarchical relationship between the inside/outside of state power shaped new strategies of subjugation and resistance. Much emphasis was placed on under-communicating power differences and hierarchies between el pueblo and officials, at the same time as these hierarchies were constantly negotiated-sometimes directly and sometimes indirectly. In particular, representatives of the state and the government frequently alluded to poder popular in order to signalize that they were aligned with el pueblo, at the same time as people used the concept of popular power as a discursive strategy to push or challenge state and political officials.

Moreover, political discourse was markedly "popularized," in the sense that it was explicitly anti-elitist. A prime example of this popularization was of course Chávez, who mastered the popular language to the fingertips, even when he spoke about complex political and economic issues. However, a popularized political discourse, emphasizing informality and colloquiality, was deployed in a variety of settings. This included the interaction between high-level politicians and public functionaries and community members. In the following example, we will see how this played out at a public meeting in 23 de Enero with Jorge Rodriguez, the thenmayor of the Libertador Municipality.

\section{A Visit from the Mayor}

The purpose of the meeting was the inauguration of the new mayor's pilot program: Plan Caracas Socialista. Plan Caracas Socialista was an urban infrastructure program that would be carried out in close cooperation with the communities through the formation of gabinetes sectoriales (sectorial cabinets), which would include all social movements (communal 
councils, colectivos and other groups) in the area and the representatives from the municipality.

The meeting took place at Plaza la Juventud in La Cañada, located between the bloques and the road leading up the roundabout of bloque seven. A small stage was set up, with rows of chairs under a red-and-white baldaquin. A lot of people showed up, both from La Cañada and adjacent sectors. After having been introduced by Guadalupe, one of the leaders for the Colectivo Coordinadora Simón Bolívar, Jorge Rodriguez greeted the community and started to explain how the projects would proceed. At one point, in the midst of the explanation, a man in the audience shouted from the back: "But what about barrio Sucre?" Rodriguez responded: "Ah, I'm getting there, compadre, I am getting there." Later in his speech, another woman shouted out: "In El Observatorio there are bloques without doors," to which Rodriguez responded "I know amor mio, like I am telling you, in less than a month we will start up there." Throughout his speech, he often used hermanas and hermanos (brothers and sisters) to address the crowd.

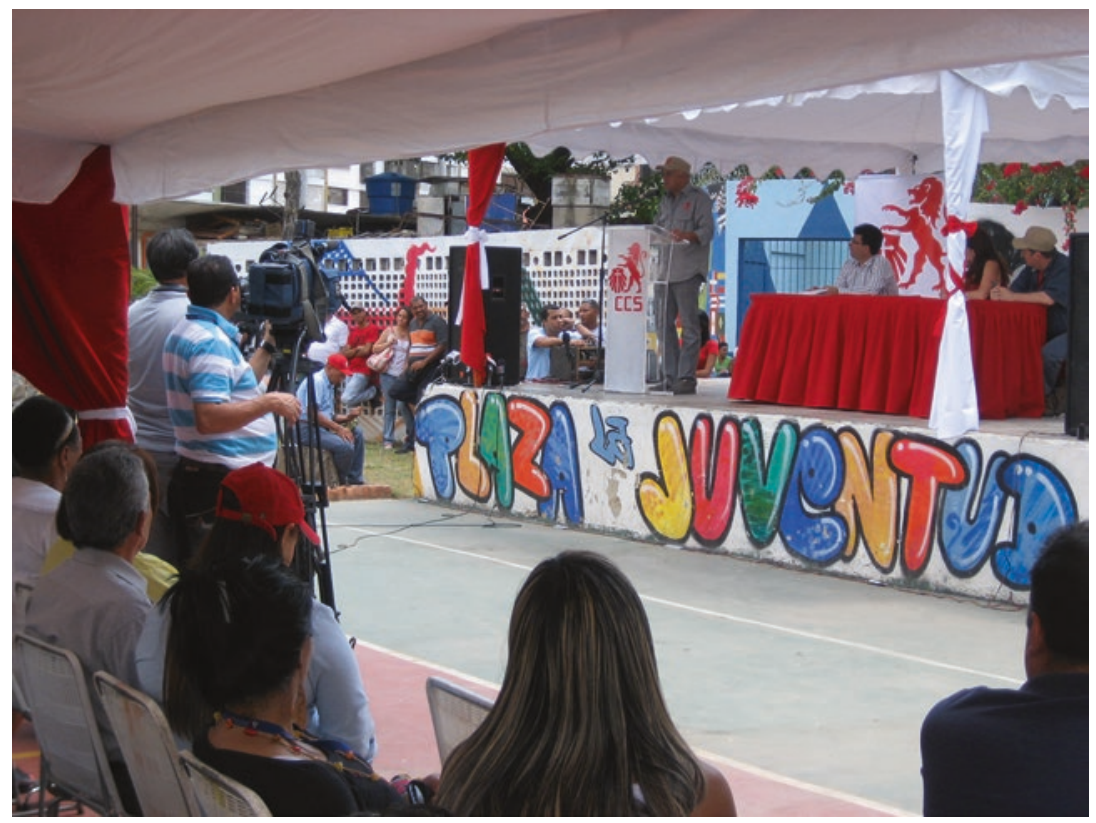

Photo 7.3 Public meeting with Jorge Rodríguez, the mayor of the Libertador Municipality, in 23 de Enero. Photo by the author 
Rodriguez's choice of words is not insignificant. Compadre, literally meaning godfather, is an expression that is most commonly used between equals. Similarly, amor mio, my love, is a colloquial way of addressing both friends and strangers (e.g., in shops) though the form mi amor is more common. Hermano and hermana are also ways to address other people to indicate equality and friendliness. By using these forms to respond to comments, Rodriguez was signaling colloquiality, equality and intimacy. ${ }^{7}$

Jorge Rodriguez, a psychiatrist by trade, is the son of Jorge Rodriguez, the leader of the political movement and party, Liga Socialista, who was beaten to death by security agents in 1976. Even though Rodriguez has a middle-class background, he has intimate knowledge of popular sector political discourse and sociality.

The social and political background of the Chavista leadership is significant for understanding how the social interaction between popular sector communities and public officials unfolded within the Bolivarian space. As Caldeira notes: "In hierarchical societies, access to political speech is generally a privilege of the dominant class. Word and power are associated" (Caldeira 1988:452). Through the Bolivarian process, the poor acquired an advanced mastery of political speech, and they frequently had access to forums where they could engage with politicians directly. Moreover, politicians and community activists shared the political discourse and symbolic universe of the Latin American left. This created a platform for negotiating differences through discourse as the popular sectors could assert themselves through rhetorical devices and political references autochthonous to them.

\section{WanT TO TALK ToO}

The following example illustrates how the notion of popular power was invoked to negotiate hierarchy at a meeting concerning the passing of the new law for the communal councils in 2009. A large tent, in white and red, had been set up outside the National Assembly, downtown Caracas. Various representatives from the National Assembly and community activists were present. The members of the Comision Permanente de Participación Ciudadana, Descentralización y Desarrollo Regional (Permanent Committee for Citizen Participation, Decentralization and Regional Development) held long speeches about the loopholes in the 2006 law, and about the new provisions of the reformed law. Afterward, 
the floor was opened to questions. Nicolas, an elderly man from a communal council in El Junquito took the microphone and said:

First of all I want to greet my beloved comandante Hugo Rafael Chávez Frías for moving this forward, for being fascinated, ${ }^{8}$ and secondly, to the representatives that have spoken because they have dedicated themselves really, paying attention to details and I am really satisfied with how this is going. Now, listen, I want to propose that there isn't only space for questions here, because si yo soy poder popular (if I am popular power) it cannot be that you only allow me to ask a question, I want to say something in depth.

Nicolas then made a lengthy and well-formulated speech that was well received by the audience. Afterward, one of the national assembly representatives followed up on some of the points Nicolas had made in a respectful and serious manner. As Sharma and Gupta note: "Everyday statist encounters not only shape people's imagination of what the state is and how it is demarcated, but also enable people to devise strategies of resistance to this imagined state" (Sharma and Gupta 2006:17). Through his speech, Nicholas signalized that the state representatives could not set themselves above the representatives of popular power through dictating the agenda and form of the meeting. His choice of words was readily understood by the members of the National Assembly, who then adapted to the claims that he was making. Indeed, more often than not, power holders would put emphasis on signalizing equality and that the floor was open for debate. However, on a few occasions, I observed more conflictual dynamics emerging from the trespassing of acceptable displays of power and hierarchical difference.

\section{Deflecting Criticism}

One such occasion was a meeting in the national theater of El Capitolio, in the center of Caracas. It was an important event, and the mayor, the minister of culture, the minister of the commune and Jacqueline Farías, the head of the government of the Capital District (Distrito Capital), were supposed to be present, together with representatives from the communal councils from all across western Caracas. The purpose of the meeting was to present a summary of the proposals that had been elaborated by extensive popular participation for the reform of the Law for Communal Councils. 
Parallel popular assemblies had taken place all across Caracas in the previous weeks, and involved approximately 2600 people. The assemblies were organized both as plenary discussions and as work groups, where each group, comprising of an average of 35 people, had elaborated a detailed analysis, with corresponding proposals for reforms of the law, for the communal councils. From all this work, five documents, each representing one eje (axis) of Caracas, ${ }^{9}$ had been elaborated, summarizing different points of view, which were now to be officially presented to the authorities. This would form the basis for the reform.

The meeting was scheduled to take place on Sunday at $10 \mathrm{am}$, but it didn't start until about three hours later. In the meantime, those who waited outside and inside the theater had been given breakfast in takeaway boxes-yogurt, ham and cheese sandwiches and orange juice. When the meeting finally started, it was announced that neither the mayor nor the minister for the commune would come. The leader of the meeting was Jacqueline Farías who held an introductory speech, after which the spokespeople for the five axes presented their main points on Power Point slides.

Many people were eager to address the panel, but Farías said that a general discussion was not scheduled and would not take place. One woman took the microphone and shouted angrily: "We have been here since nine o'clock in the morning, and now you are telling us that only five people are allowed to speak? Everyone who wants to should be allowed to speak." A heated discussion erupted as others joined the woman's protest.

To distract the crowd, Jacqueline Farías stated that "we have more important enemies than our own politicians" and that "here we are all from el pueblo, and even if today I have this position, on another occasion it will be you." In my field notes, I wrote that she seemed a bit defensive and that her attempts to distract came across as quite patronizing. She was saved by a young woman from Gramoven, an area in Catia that was known for high levels of organization, who was a relatively well-known community activist. She argued that the political representatives were doing the best they could to attend to all the different areas they were responsible for. Shortly thereafter, the discussion died out, and the meeting ended. It was obvious that some of the people wanted a discussion with more substance, as they had put in a lot of time and effort into working out these proposals. (The previous day I had participated in a full-day discussion and summary session in the axis that corresponded to 23 de Enero.) The fact that the few politicians that actually showed had showed up late (even though no meeting ever starts on time) added to the frustration. 


\section{A Contested Bolivarian Space}

Throughout the past three chapters, we have explored, from various angles, the interface between popular politics and state politics within what I have called a Bolivarian space. I have emphasized the contested, conflictive and at times contradictory dynamics that emerged as the ideals, ideology and politics of the Bolivarian process rubbed against political structures, ingrained social practices and heterogeneous social actors and interests. In particular, I have emphasized an in-depth understanding of "the local" as a point of departure for understanding how grassroots politics was unfolding with popular sector communities and in close interaction with the state.

Chapter 8 will continue this line of exploration, but from a different angle. We will now turn our attention to how the templates, practices and values associated with oil wealth gained salience in the crafting of a Bolivarian ideology and corresponding new social, cultural and political practices. Specifically, I will explore how notions of money, wealth, consumption, individualism, greed, and corruption can be traced back to the nation's history as an extractive state. Concurrently, I will show how these contested moralities and values translated into a deeply ambivalent and unstable terrain for the unfolding of the Bolivarian process at the level of everyday political dynamics as well as for its ideological underpinnings.

\section{Notes}

1. This event took place in the spring of 2009. In order to adapt to the new legal framework of the reformed law from the communal councils, the councils had to go through a process called adequacion (adjustment), which implied calling for new elections and re-registering with Fundacomunal.

2. Fieldwork interview, Eliér Gonzales, director of Fundacomunal in western Caracas, spring 2009.

3. Fondemi is a state institution that gives credits (which have to be repaid) to socio-economic projects boosting local economic activity.

4. The communes were envisioned as progressively becoming instances of auto-gobierno (self-government) consistent with the ethos of the Socialism for the twenty-first century.

5. This was a referendum over amendments of five articles of the constitution (a modification of the original proposal that was turned down in a referendum in 2007, see Chap. 4).

6. Note that negrita is not meant disrespectfully in this context. It is a common expression among peers, both used for those who clearly have African heritage and for those that have a whiter skin tone. 
7. In Bolivarian political discourse, compañeros/as is the most common way of referring to someone. It is also frequently used in political settings where politicians or public officials interact. It is important to note that Venezuelans are relatively more informal in their everyday interactions than in many other Latin American countries. The formal version of the pronoun you, usted, is frequently omitted in everyday speech, and people commonly address each other as tú (informal version of you). Professional titles are however frequently emphasized in formal and semi-formal settings (e.g., licenciado/a, doctor/a, maestro/a, professor/a) and pupils and students commonly address their teachers as maestro/a or professor/a. Usted may be used out of respect in some contexts signalizing formality or hierarchies, and it can also be used to maintain a certain distance from a speaker. In the street, people address each other in a number of ways according to sex and gender. Mi amor (my love) is a relatively common way to address strangers in a range of everyday context, both men and women. Men can address each other as pana (buddy) or hermano (brother) if they want to create a situation of friendliness or informality, even to a stranger.

8. Fascinated, in this context, means engaged, dedicated.

9. The division of Caracas into axes (ejes) is a part of the new geo-political restructuring that was proposed by Chávez in his amendments to the constitution. The different axes are based on strategic evaluation of the characteristics, needs and potential of each area, constituting an "overlapping" political map, in addition to the formal territorial divisions between parishes and municipalities.

\section{BiBLIOGRAPHY}

Alvarez, Rosángel, and María Pilar García-Guadilla. 2011. Controlaría social y clientelismo: La praxis de los consejos comunales en Venezuela. Politeia 34 (46): 175-207.

Appadurai, Arjun. 1990. Disjuncture and Difference in the Global Cultural Economy. Public Culture 2 (2): 1-24.

Caldeira, Teresa. 1988. The Art of Being Indirect: Talking about Politics in Brazil. Cultural Anthropology 3 (4): 444-454.

Ciccariello-Maher, George. 2016. Building the Commune. Radical Democracy in Venezuela. London and New York: Verso.

Cooke, Bill, and Una Kothari. 2001. Participation: The New Tyranny? London and New York: Zed Books.

Ellner, Steve. 2009. A New Model with Rough Edges: Venezuela's Community Councils. NACLA Report on the Americas 42 (3) (May/June): 11-14.

Ferguson, James. 1994. The Anti-Politics Machine: Development, Depolitization and Bureaucratic Power in Lesotho. Minneapolis and London: University of Minnesota Press. 
Fernandes, Sujatha. 2007. Barrio Women and Popular Politics in Chávez's Venezuela. Latin American Politics and Society 49 (3): 97-127.

Gupta, Akhil. 1995. Blurred Boundaries: The Discourse of Corruption, the Culture of Politics, and the Imagined State. In The Anthropology of the State. A Reader, ed. A. Sharma and A. Gupta. Oxford: Blackwell Publishing.

- 2001. Governing Populations: The Integrated Child Development Services Program in India. In States of Imagination. Ethnographic Explorations of the Postcolonial State, ed. T.B. Hansen and F. Stepputat. Durham and London: Duke University Press.

Irazábal, Clara, and John Foley. 2010. Reflections on the Venezuelan Transition from a Capitalist Representative to a Socialist Participatory Democracy. What Are Planners to Do? Latin American Perspectives 37 (1): 97-122.

López, Margarita M. 2011. Hacia el socialismo del siglo XXI: Los consejos comunales, sus cambios conceptuales y las percepciones de los participantes en Caracas. In Ciudadania y Legitimidad Democrática en América Latina, ed. I. Cheresky. Buenos Aires: Prometeo.

Machado M., Jesús E. 2009. Participación social y consejos comunales en Venezuela. Revista Venezolana de Economía y Ciencias Sociales 15 (1): 173-185.

McNeish, John-Andrew. 2001. Pueblo Chico, Infierno Grande. Globalisation and the Politics of Participation in Highland Bolivia. PhD dissertation, Department of Anthropology, University of London.

Mitchell, Timothy. 2006. Society, Economy and the State Effect. In The Anthropology of the State. A Reader, ed. A. Sharma and A. Gupta. Oxford: Blackwell Publishing.

Motta, Sara. 2013. "We Are the Ones We Have Been Waiting For": The Feminization of Resistance in Venezuela. Latin American Perspectives 40 (4): 35-54.

Pedrazzini, Yves, and Sanchez R. Magaly. 1992. Malandros, Bandas y Niños de la Calle. Cultura de Urgencia en la Metropoli Latinoamericana. Valencia and Caracas: Vadell Hermanos Editorial.

Pigg, Stacy Lee. 1996. The Credible and the Credulous: The Question of "Villagers' Believes" in Nepal. Cultural Anthropology 11 (2): 160-201.

Rakowski, Cathy A., and Gioconda Espina. 2011. Advancing Women's Rights from Inside and Outside the Bolivarian Revolution, 1998-2010. In The Revolution in Venezuela. Social and Political Change under Chávez, ed. T. Ponniah and J. Eastwood. Cambridge, MA: David Rockefeller Center for Latin American Studies, Harvard University.

Scott, James. 1985. Weapons of the Weak. Everyday Forms of Peasant Resistance. New Haven and London: Yale University Press.

-1999. Seeing Like a State: How Certain Schemes to Improve the Human Condition Have Failed. New Haven and London: Yale University Press.

Sharma, Aradhana, and Akhil Gupta. 2006. The Anthropology of the State: A Reader. Oxford: Blackwell Publishing. 
Strønen, Iselin Åsedotter. 2013. En feministisk revolusjon? Kvinner, kvinnekamp og aktivisme i Chávez' Venezuela. Norsk Antropologisk Tidsskrift 1 (24): 39-51.

Sunstein, Cass. 1998. More Is Less. Review Article of Seeing Like a State: How Certain Schemes to Improve the Human Condition Have Failed by James Scott. The New Republic 37.

Willson, Margaret. 2007. Dance Lest We All Fall Down: Breaking Cycles of Poverty in Brazil and Beyond. Seattle: University of Washington Press.

Open Access This chapter is distributed under the terms of the Creative Commons Attribution 4.0 International License (http://creativecommons.org/ licenses/by $/ 4.0 /$ ), which permits use, duplication, adaptation, distribution and reproduction in any medium or format, as long as you give appropriate credit to the original author(s) and the source, provide a link to the Creative Commons license and indicate if changes were made

The images or other third party material in this chapter are included in the chapter's Creative Commons license, unless indicated otherwise in a credit line to the material. If material is not included in the chapter's Creative Commons license and your intended use is not permitted by statutory regulation or exceeds the permitted use, you will need to obtain permission directly from the copyright holder.

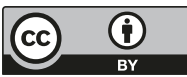




\section{Moralities, Money and Extractive Capitalism}

Venezuelans know the price of everything and the value of nothing

Venezuelan actor and intellectual Julio Motta, cited in Strønen and Wærness (2007)

Caracas, spring 2011: I was sitting on a tall bar chair in a little DVD and CD stall located in a small and worn-down basement shopping mall close to La Hoyada, in downtown Caracas. I was doing an interview with Ricardo, a family man in his 30s from 23 de Enero, and a newly elected vocero (spokesperson) for the communal council in his street. He was the owner of the stall, and I was interviewing him as passing customers stopped for a peek, to purchase something or for a chat. Ricardo had recently been elected vocero for the Committee for Ideology. At the meetings I had attended in his community, he was always trying to cut through the quarrels, urging people to come to their senses, stop fighting and rather think about the collective good. The community was in the midst of finalizing housing projects that would benefit around 20 families. This was a project that had been going on for a long time, causing a lot of rifts, quarrels and dirty maneuvers among the neighbors. Now, the money seemed to be on its way, and with some secret horse-trading and heated public arguments, the matter of who would be benefiting from it was settled. However, it had been a long process. Allegations of robbery, fraud and ulterior motives had stirred tempers and caused the consolidation of two factions in the community competing to gain control over the process. Ricardo was frustrated about his community and the way people behaved: 
When resources are given to us, the communal council in each parish has to be sincere, honest, right? We cannot get greedy when we see the money, because you know one thing, the money is the enemy, money cannot be viewed as raw (en bruto) because then the person becomes distracted or corrupted, just by the thought of taking a piece of this, right?

And that is already egoism, because you cannot ... one cannot think of this, but you have to think that it is for the community, because it belongs to the community as such and if a person is going to carry out a project and in the long run resources are diverted, then we are falling into the same trap as before, then we are not making a real effort to change.

The idea is that that resources are transferred for projects for the future, that no one skims off a bolivar because then we are doing ... I am talking from my point of view, if anyone skims off the minimum of a céntimo, then unfortunately everything is ruined. Why? Because then we are entering into corruption, and if I see that this person skimmed off a céntimo, then the other person also wants a céntimo and when everyone wants, then in the end of the day nothing is done.

With these comments, it was as if Ricardo attributed to money an uncanny ability to corrupt the person who sees it. Money is not to be seen "raw," he says: "If I see that this person skimmed off a céntimo, then the other person also wants a céntimo and when everyone wants, then in the end of the day nothing is done." Like the Coca Cola bottle that falls down in the middle of the Kalahari Desert in the film The Gods must be Crazy (Uys 1980), money has the ability of making everyone fall under its spell and eventually making everything fall apart.

Ricardo's choice of words was not unique. Often, people lamented how the seductive power of money was working against the Bolivarian process from within, engendering conflicts and corruption; promoting "individualism," egoism, greed and consumerism; and preventing a revolutionary consciousness from gaining foothold. These templates were talked of as the products of the country's capitalist history during the Fourth Republic, and how the implementation of neoliberalism by corrupt politicians from the 1980s onward had wrecked society from within.

By way of contrast, these historical experiences, and their imprint on the social and political body, were contra-posed to a new morality in the making: a revolutionary, socialist consciousness promoting collectivism, unity, integrity and solidarity. In this process, "Che's New Man" was to 
be born-the new man and woman that according to Che Guevara would develop through both material and moral incentives, as the revolution converted society as a whole "into a gigantic school" (Guevara 2003 [1965]:216).

In Venezuela, the concept "Che's New Man” was occasionally used by the more ideologically oriented: popular intellectuals, state officials and politicians, and Marxist-schooled activists. But discourses articulating "folk wisdom" also constantly reiterated that the Bolivarian process had to reverse capitalism's "vices" and engender a new social and political order, changing both the rules of politics and people's values and everyday life practices.

\section{Destructive Social Facts}

These ideas were often explicitly or implicitly tied to the template of oil; oil had since long ago generated a culture of voracious individualistic rentseeking among the elites and corrupted Venezuelan society. Now that oil wealth circulated in all spheres of society, the vices that it engendered were filtering down to ordinary people who behaved as if "my drop of oil" was finally up for grabs. Coronil has noted that: "As an extraordinary valuable commodity, it is hard for people to control [oil], particularly when it undergoes its most dramatic metamorphosis: when it becomes money" (Coronil 2008). As I delved deeper into Venezuelan history and social symbolism, I became increasingly fascinated by how the notions of capitalism, money and oil converged in templates and narratives of immorality and social destruction, bringing associations to Durkheim's “social facts." Oil wealth and extractive capitalism was viewed as having debased Venezuelan society since long ago through engendering particular sets of harmful norms, values and practices. If not countered and replaced with new moral economies and values, this legacy would destroy the Bolivarian process from within. The destructive power of oil was thus not only tied to its effects upon the political game and the economy, but also over people's hearts and minds.

\section{New Moral Economies}

Community politics was viewed as a key site for the emergence of new social and political relations through the crafting of new values and moralities. I use the concept of moralities in this context as a notion that "con- 
tain and express both discourse and practice" (Howell 1997:4). Moralities are not static templates, but rather founded on values that are susceptible to change through practices (ibid.). Analogously, practices considered conflictive, individualist, opportunist, scheming, and dishonest were frequently denounced, negotiated and mediated through a moral discourse emphasizing la falta de valores (lack of values) characterizing Venezuelan society.

I believe that it is paramount to understand the conflictual and contradictory nature of these processes not as a result of individual "virtues" or "deviances," or as evidence of the nation's "pathologies," but rather as the outcome of a series of historical, cultural, social and political processes. We need to capture how Venezuela's experience with oil-saturated capitalist-and later neoliberal-economic, political and social formations, were conceptualized within a moral and value-laden repertoire. In that frame of mind, we are better equipped to capture how contested practices, and the way these were conceptualized through discourses of moralities, constituted a focal point whereby the historical formation of Venezuelan state and society was placed in juxtaposition to the Bolivarian vision of a new social order.

\section{Neoliberalism and the Social}

Within academia, as well as the realms of policy-making, realpolitik, political activism and folk wisdom, the concept of neoliberalism is deployed in highly heterogeneous ways. In its orthodox economic sense, neoliberalism is often presented (by its proponents) merely as an economical-political restructuring of society whereby the role of the state is reduced in order to obtain a better, and supposedly socially more beneficial (at least in the long run), distribution of goods and services through an unhindered market. Scholarly criticism of neoliberalism does not only concern the kind of policies it promotes, and its frequently harsh social consequences in the form of increased poverty and inequality, but also the ways in which it works at an ideological level. As Gledhill notes:

What makes neoliberalism something that a classic liberal such as Adam Smith would have found as disturbing as Pope John Paul II does is its elision of the distinction between a market economy and a market society, to the point where the latter seems to engulf life itself. (Gledhill 2004:340, emphasis in original) 
Sandel, in his "Tanner Lecture on Human Values" delivered at Oxford in 1998, maintained that "one of the most powerful social and political tendencies of our time [is] the extension of markets and of market-oriented thinking to spheres of life once thought to lie behind their reach" (Sandel 1998:93). This blurring of boundaries between what belongs to the market and what doesn't is a powerful threat to society at large, he argues, as it blurs the boundaries of what can be bought and sold. Moreover, the increase of social and economic inequalities combined with the marketization of expanding spheres of human life undermines the republican ideal, dating back to Aristotle and Rousseau, of society as a common civic sphere. Tanner concludes his speech with the observations that there are certain "moral and civic goods that markets do not honor and money cannot buy" (Sandel 1998:122).

A consequence of the expansion of market thinking to the heart of civil life and public services is that citizenship-historically a notion capturing the relationship between rights and duties of the individual, the wider polity and the state- has been replaced with notions of consumer citizenship. As Scammel has noted: "It is no longer possible to cut the deck neatly between citizenship and civil duty, on the one side, and consumption, and self-interest, on the other" (McGregor 2002:20). The marketization of society has transformed the community and collective good into an obsolete imaginary object; each one of us is supposed to navigate within the array of market opportunities "offered" to us. A failure to do so is attributed to individual deficiencies, to a deviance from the free, self-creating individual that neoliberal ideology is founded upon.

\section{UndERSTANDING LOCAL INTERPRETATIONS OF CAPITALISM}

There are significant differences between how market capitalism and neoliberalism have been absorbed in the Global North and in the Global South, and indeed between countries and regions in each sphere (Harvey 2005). These differences do not only concern how policies have been implemented, but also how reforms have interacted with the broader social, political, economic and cultural fabric. Anthropologists have, during the past decades, produced a broad array of ethnographic accounts documenting people's reactions to the high noon of capitalism in different parts of the world (e.g., see Comaroff and Comaroff 1987, 1999, 2001; Englund and Leach 2000; see also Ortner 2016). One of the most well-known accounts from Latin America about capitalism's 
effect on "traditional" societies is Michael Taussig's The Devil and Commodity Fetishism in South America (1980). Building upon Marxist theories of value as well as Marx's notion of commodity fetishism, he explores how the devil, in local folklore among African-Colombian plantation workers and Ayamara Bolivian tin miners, becomes an idiom through which the destructive effects of capitalism upon human and social relations are mediated. Through this account, Taussig argues that rather than seeing folkloric tales as irrational peasant believes, it is from the fringes of the capitalist economy that the enigma of capitalism can best be captured: "They provide us with insight into the irrational bias of our own economy and stereotype of homo oeconomicus" (Taussig 1977:475).

Capitalist critiques, with a Marxist underpinning, have always held sway over Latin American popular intellectuals and academic scholarship on Latin America alike, perhaps because the exploitative force of capitalism has always been so blatant. The ideological twins of Western modernity; the templates of liberal democracy and market capitalism, have been eagerly embraced by state builders at various historical junctures. However, following Polyani's insight that "markets thrive on formal equality combined with brutal inequalities in practice" (see also Sandel 1998; Hoffman and Centeno 2003; Weyland 2004; Fourcade and Healy 2007:293) there has often been a simmering resistance to, or at least ambivalence toward, "capitalism" among those who are excluded from, or unequally embraced by, its virtues (Gledhill 1995; Nugent 1996). This collusion between the economic paradigm of capitalism, the implementation of formal liberal democracy, and class politics is important in order to understand how the narrative of the Fourth Republic and its social, political and moral degeneration played out in the course of the Bolivarian process.

\section{Neoliberalism and the Social Body}

In Chap. 2, I outlined how the breakdown of the oil-fuelled developmentalist paradigm and the installment of neoliberal "shock treatment" caused a political and social havoc from the 1980s and forward. These processes spurred the deepening of social problems among those that were already most vulnerable in Venezuela. The incapacity of the market economy to incorporate the rapidly increasing informal urban population created a "surplus" population forced to scramble for its survival on the margins of society. Urban informal growth strained the barrios' already limited and inadequate infrastructure. The poor's inability to participate in the 
increasingly commodified "welfare market" relegated them to a state of permanent scarcity, insecurity and a sense of existential precariousness. The increasingly open hostility of the state, which by the end of the 1980s had abandoned its pretense of advocating for incorporating "the popular" into the state and nation body, relegated them to a condition of demeaning otherness. This perpetuated the sense of being cut out not only from a narrative of the nation-state itself, but also from the aspirations of a life project. At the same time, real wages declined and working conditions became worse, increasing the sense of exploitation and perpetual hardships.

As a result of these processes, people experienced not only a pulverization of the faith in the political system at large, but also a crumbling of the social fabric in the popular sector communities. People recount that their communities were previously experienced as quite meaningful and tightly knit social worlds in spite of abject poverty. They had their problems, and life was harsh indeed, but a sense of local security, collective local life and collective aspirations for the future still prevailed.

From the 1980s and onward the future was "called off." Social problems emerged on a large scale: violence and crime, the expansion of a violent drug economy, alcohol and substance abuse, an increased presence of weapons, life tragedies and family tragedies, a brutalization of collective spaces and subsequent retreat from communal life, acute needs, suffering and death. Life was experienced as a perpetual struggle to make ends meet, and significantly, a sense of being at war against each other as poverty became more aggravated and social needs became individualized. People experienced social trust and respect for others vanishing and informal social control mechanisms breaking down. In short, they experienced both a loss of meaning and a loss of a moral community and a collective future (see also Lander 2005).

It is important to understand these narratives as epistemological and ontological "truths" derived from people's real-life experiences. Not only do these referents undercut contemporary critique of capitalism's fragmentary, individualizing and violent effects, but they also help explain why Chávez's attacks on "capitalism," viewed by the Western press as oddities and derailings of a flamboyant populist, resonated with ordinary people. For them, "capitalism" epitomized a broader embodied understanding of social disintegration and anomalies that had permeated their individual lives and the social body throughout the past decades. 


\section{OIL SOCIETY}

Capitalism in Venezuela-both as a socio-economic model and as a social imaginary-cannot be properly understood unless we also capture how it has shaped and has been shaped by the country's oil wealth. Wealth circulation and wealth allocation in Venezuela, as well as social and political imaginaries, are born from this dialectic. Writing about oil wealth is always difficult. Oil constitutes a tangible substance, and at the same time, its representations are steeped in an enigmatic veil engendering imageries of certain pathological, social and political properties. As Coronil maintains, "oil does not do anything by itself," but it becomes an important factor shaping society "as it is transformed and used by people under given historical frameworks, specific historical situations and global economic context" (Coronil 2008).

Citizens in oil-rich countries are often presented as being captivated by the illusion of wealth abundance, displaying a series of behavioral traits such as sloth, chicanery and opulent consumption. Polish journalist Ryszard Kapuściński once noted that

oil creates the illusion of a completely free life, life without work, life for free ... the concept of oil expresses perfectly the enteral human dream of wealth achieved through lucky accident .... In this sense oil is a fairy tale and like every fairy tale a bit of a lie. (Watts 2004:213)

For his book Petromania (2009), Norwegian journalist Simon Sætre traveled to several of the world's oil countries in order to find out "what oil does to us." He coins the expression homo petrolicus: not a person with innate pathologies per se, but rather a person that adapts to the environment he or she is embedded in, following certain behavioral patterns caused by the centrality of oil wealth in public life.

The notion that oil wealth engenders particular social dynamics is a familiar one (Apter 1993; Karl 1997, 1999; Watts 1999). However, I posit that it is paramount to discern exactly how socially embedded "oil cultures" are articulated in everyday life practices, ideas of personhood and state-society relations at particular historical conjunctures. Thus, through exploring particular cultural idioms associated with money and oil wealth, such as consumption, individualism, corruption, egoism, values and greed, we may achieve a deeper understanding of the contested cultural qualities that the particular Venezuelan experience of oil-fuelled capitalism has engendered. 


\section{Conspicuous Consumption in Venezuela}

Cash is king in Venezuela. La plata, los reales, los billetes, however you call it, money gives you status, money gives you friends, money gives you power and not least, money gives you women.

For the rich: the opulent mansions and haciendas in Venezuela, their houses in Miami and the Dominican Republic, the SUVs, the surgically enhanced trophy wife or girlfriend, the upscale restaurants and clubs, the farandula (celebrity parties), the vacations to luxurious destinations, the jewelry, the designer clothes, the hair, the nails, the makeup, the maids and nannies.

For the middle classes: the constant struggle to move upward through symbolic consumption mimicking upper-class lifestyles as best they can. The commodification of the female body. The obsession with Western (read: US) consumer objects, clothes and habits, and the constant talk about what they have bought and where they bought it (preferably outside Venezuela). The flaunting show-off of conspicuous consumption.

For the "ordinary people" in the barrios: the Blackberry, the imported whiskey, the breast implants (or girlfriend with breast implants), the ceramic tile floors, the vacation to Isla Margarita (with tax-free shopping), the designer bags, branded clothes, the motorbike and so on. I have known women who spent an entire month's wage on a Louis Vuitton bag, and men who spent one-fourth of a month's rent on a bottle of whiskey. I have known a lot of people who spent at least two months of their minimum wage on a smart phone.

Guy Debord wrote: "the Spectacle is the other side of money; it is the general abstract equivalent of all commodities" (Debord 1967:1). The trips to shopping malls on the weekend: the opulent, glitzy shopping malls converted by rich and poor alike into something akin to a shrine: its shiny galleries, silent escalators and greasy, over-crowded fast-food courts. The malls have become the site of a bizarre self-conscious ritual, a site for confirming the atomized, yet collective triumph of modernity. The replica of the Statue of Liberty, four-stories tall, in the center of the El Recreo mall, in Central Caracas. Fervent little girls and boys enter the gates to consumer heaven, while a man carries his super-mega combo order of Kentucky Fried Chicken over to his family's plastic table as if he were carrying a tray of the finest oysters and champagne. 


\section{The Boom}

These were the years before the economic crisis set in, still the years of the vaca gorda (fat cow), when Venezuela's BNP was still pointing upward, inflation was still manageable and consumer products were readily available. Yet, the disparity between wages and consumption puzzled me; it didn't make sense. Money seemed to be everywhere, flowing from hand to hand, endless streams of transactions, deals, favors, trickeries, rebusques (inventive ways of generating extra income). Venezuelans were amazed themselves: at Christmas time everyone spoke about how crowded the streets were, how the consumption rates had hit the roof, how certain sought-after items (especially name-brand children's toys) were out of stock across Caracas. At every Easter and Christmas holiday, tickets for buses, boats and planes were sold out for practically all destinations and people would comment: "They say that things are going bad here, yet everyone is going on vacations." People in the barrios talked about how the streets had become more and more congested because of car sales hitting the roof, of how increasing numbers of barrio women had gotten their boobs and buttocks done, ${ }^{1}$ of how "everyone" had a Blackberry (though many didn't have money to use it) and not least, how people were now being killed in the street for their smart phones. Despite a collective acknowledgement of how the alluring symbols of wealth posed a threat to the social fabric, the golden calf continued to be worshipped nonetheless. The spectacle of consumption was so powerful that one could start to wonder if there was any poverty left, or if those who didn't partake in the fiesta were just too principled, or simply not cunning enough. Money seemed to have an uncanny yet ubiquitous existence in the midst of a political process that not only sought to sow the idea of creating a society based upon socialist notions of the collective good, but which also denounced consumption as one of the evils of capitalism.

\section{The Ambivalence of Wealth}

The ambivalence of wealth is a thin red line running through Venezuelan modern history. Coronil has written about how Venezuela's black gold became vested with magical, yet destructive powers, vowing to lead its citizens toward the promised land of development, modernity and prosperity - a siren's song that never materialized (Coronil 1997). Indeed, the symbolic representations of wealth, status and money in Venezuela cannot 
be understood separately from the manner in which oil wealth has circulated both as an imagery and as a source to great wealth throughout the social and political body. It divided the population between those who consumed and those who stood on the outside looking in on the consumer spectacle, ascribing power to those who could possess the conspicuous symbols of wealth, and creating both desires and resentments among those who could not.

Many authors have pointed to the emergence of a culture of conspicuous consumption developing in Venezuela as oil rent started to circulate in society in the first half of the twentieth century (Ewell 1984; Hillman 1994; Coronil 1997; Tinker Salas 2009). This was not only offset by the increasing influx of North American and European consumer goods, but also by an increasing volume of North American media sources such as TV, print and newspapers (Ewell 1984:134-144) as well as by the presence of North American oil companies (Tinker Salas 2009). As we discussed in Chap. 2, the latter not only implied the general formation of an imagery of national progress and modernity via oil-financed development actively conjured by the oil companies (Tinker Salas 2009). It also implied an increasing contact between segments of the Venezuelan population and North American residents - oil managers, oil workers and their families - whereby North American consumer values and class symbolisms were absorbed by a rapidly growing population in search of a national identity (Tinker Salas 2009). These factors created a process of cultural reconfiguration whereby the national imageries of class identities as well as modernity, development and progress were associated with the ability to consume "US style."

The first government of Carlos Andrés Pérez, in the 1970s, deepened and added new dimensions to this cultural imagery. Vowing to propel the country into first-class status financed by the booming oil wealth, the government flushed enormous amounts of money throughout the system. Ruthless corruption and rent-seeking made the upper classes perversely rich, "flaunting their loot" (Coronil 1997:360) in public. As Duno (1975) worded it: "Clothing, automobiles, jewelry, mansions, trips, yachts, more and better clothing, automobiles, jewelry, mansions, trips, yachts" (Duno 1975:58, cited in Coronil 1997:337). Middle-class Venezuelans went on shopping trips to Miami for the weekend, giving birth to the idiom está barato, dáme dos (it is cheap, give me two). Symbolically, PDVSA employees often flew with the company's planes for their leisure trips. Venezuela 
became known internationally as Venezuela Saudita. An article written in 1978 by Caracas correspondent Peter Arnett in the US newspaper News and Courier reads:

Buy a 3-foot tall Salazar of French champagne from your local supermarket, price 459 USD including the ice to chill it. Transport your purchase in a USD 45,000 white Mercedes Benz sedan from any one of a dozen nearby dealer. And discreetly drink it with your secretary in any one of a dozen private clubs, membership fees up to USD 100,000. All these items are available and have ready buyers in Caracas, the capital of Venezuela, where cascading oil wealth has given new meaning to the cliché "boom town." (Arnett 1978)

The article cites a US embassy official who "fretted" that "he felt more underprivileged here than any other place in the world," and made reference to the daily Pan Am 747 flight called the "Disneyland Shuttle" between Caracas and Miami that returns "each evening with exhausted big spenders laden with purchases." Referring to the nouveau rich oil-spurred spending in Saudi Arabia, the journalist interviews a Swiss hotel manager who has worked in Saudi Arabia, who says that "the Venezuelan are much more light-hearted about spending money than the Arabs ... they enjoy it more I think." The article also mentions the poor who observe the downtown spending spree from the shantytowns hills, quoting a US government report which estimates that one-third of the country's population is ill-fed, ill-clothed, ill-housed and ill-schooled. However, the author notes that the social unrest found in other Latin American countries with great economic inequalities seems to be lacking. He quotes a Caracas journalist saying that: "They think they'll get money too. It seems so near" (Arnett 1978).

As we now know, this boom only lasted four more years. By then, the national imagery of material culture had been saturated with conspicuous consumption US style, a trait that continued to shape national identities also in the decades to come. Thus, paradoxically, while during this epoch the government of Carlos Andrés Pérez pledged to modernize the country and bring it on the path to prosperity and development-in itself a collective project of state building - an increasingly powerful individualized notion of modernity was perpetuated, that of wealth, power and success displayed by crude consumption. 


\section{The Power of Conspicuous Consumption}

As should be clear by now, I am not concerned with consumption per se. Rather, my interest is to unearth what discourses about consumption can reveal about how popular sector activists conceptualized the Bolivarian process, and the ways in which the template of consumerism gained salience in discourses about capitalism's effect on Venezuelan society. As Slater (1997) puts it: "To state the obvious, consumer culture is capitalist culture" (Slater 1997:26). Consumer culture was born from capitalist arrangements of labor, capital and production, and social critique against consumerism is as old as capitalism itself. Alexis de Tocqueville, visiting the young nation of the USA in 1831, observed that:

Among democratic nations, men easily attain a certain equality of condition, but they can never attain as much as they desire. It perpetually retires from before them, yet without hiding itself from their sight, and in retiring draws them on. At every moment they think that they are about to grasp it; it escapes at every moment from their hold. They are near enough to see its charm, but too far off to enjoy them; and before they have fully tasted its delights, they die. (Alexis de Tocqueville 1904:624-625, cited in Mullins 2011:1)

In 1899, Veblen introduced the now well-known concept of conspicuous consumption, arguing that capitalist consumption was just as socially destructive as the capitalist production process itself (Fourcade and Healy 2007:291). However, while a culture of "consumerism" as such is an old phenomenon, global mass consumption, in its contemporary form, is often seen as a key feature of late-twentieth-century globalization in the form of ever-expanding flows of cultural mass imageries and mass commodities (see Slater 1997 for a thorough analysis). There is a broad body of anthropological literature dealing with novel ways of understanding the role and meaning of consumption in the contemporary world (Appadurai 1988; Friedman 1994; Douglas and Isherwood 1996; Miles 1998; Jackson 1999, 2004; Walsh 2003; Graeber 2011). As these analyses emphasize, global imageries of consumption are codified, transformed and absorbed in numerous ways in different cultural contexts. However, in its essence, the dominant imagery of consumption is shaped by a lifestyle that is intrinsically interlinked with broader notions of modernity emanating from the Global North. As Slater notes:

Consumer culture is in important respects the culture of the modern westcertainly central to the meaningful practice of everyday life in the modern 
world; and it is more generally bound up with central values, practices and institutions which define western modernity, such as choice, individualism and market relations. (Slater 1997:8)

Intersecting with broader templates of modernity such as liberalism, consumption is projected through a densely packed message of freedom epitomized by the concept of consumer sovereignty (Slater 1997:27). However, a broad body of work across disciplinary fields has dissected how the emancipatory message written into the imagery of consumption (freedom is to shop the identity of your choosing!) constitutes a very twisted or limited liberty, or liberty only for the few.

Paradoxically, the pressure to consume may be weighing in more heavily on those who do not have the capacity to consume (Miles 1998:151). Gledhill has put forward a similar perspective, arguing that "the measurement of social worth in terms of consumption and marketed 'lifestyle' symbols penetrates deeply even into the lives of the world's poorest citizens" (Gledhill 2004:340). No wonder then, that consumption often takes on a daydreaming quality; it becomes a way of imagining and fantasizing about the unattainable (Miles 1998:151).

These perspectives are important to capture, because they remind us that the poor are as equally prone to consume imageries of commodified lifestyles as the rich, creating an economy of desires and wants that intersects with a broader repertoire of power and domination, poverty and exclusion, identity formation, compliance and resistance. In Venezuela, as we learned above, the popular sectors were, throughout the twentieth century, relegated to the place of spectators witnessing their better-off fellow countrymen and women flaunt a lifestyle and level of consumption that was far beyond their reach. Indeed, during el Caracazo, it was not only food and household items that were looted; it was also TV-sets and refrigerators. As many of my informants said: "For a long time poor people had been forced to watch consumer propaganda touting what they should have. During el Caracazo some people used to opportunity to seize these things." The desire to consume had been "democratized" across society, but only a small part of the population had been able to partake in the fiesta. However, consumption took on a dark meaning for the popular sector, as expressed through the often-said truism "here will kill each other for a pair of shoes." The phrase originated in the 1980s, when the social hype around the Nike Escape models apparently led to a string of robberies and even murders. Being a tragic illustration of the localized outcomes 
of globalized messages about modern identities, the phrase "here we kill each other for a pair of shoes" remained in the popular social imagery, confirming the power of commodities in the construction of Venezuelan social identities.

\section{Consumption in the Age of Chavismo}

Consumption boomed under the Chávez government. Private per capita consumption grew more than 50 percent between 1998 and 2012. In 2013, Venezuela had 150 shopping malls for a country of almost 29 million inhabitants. In contrast, Argentina, with 40 million inhabitants had 19 malls (Informe21 2013) Throughout the Chavez period, purchasing power among the popular sectors increased significantly because of a combination of several factors: social spending targeting poor social groups, increased wages, a new oil boom and public policies creating expanded economic activities and, in turn, increased employment opportunities and circulation of capital. Due to the altered class profile of the state apparatus, more people from the popular sectors were able to access public sector employment. And with new political constellations, new public policies, and a new influx of oil resources, new channels to tap into public resources, through clientelism or corruption, were opened for new sectors of the population. Put together, these factors increased the purchasing power for people in the lower end of the socio-economic scale, and enabled them to consume beyond the level of "mere survival" as they were historically accustomed to. Now, they could also partake in symbolic consumption, and an increasing number of people did so, even if it often cost them hardship and sacrifice.

\section{Buying ON A Whim}

Many Venezuelans perceive themselves as heedless, senseless spenders, throwing out money, "here today, gone tomorrow," so thoroughly couched into a consumerist culture that they spend even if they don't need it and even if they cannot afford it. I discussed this one night with David, a young community activist, as we were sitting in his rooftop terrace overlooking the glittering lights across the valley of 23 de Enero:

DAVID: Here in Venezuela we are, we are quite consumistas, Venezuela has distinguished herself as one of the countries that 
consumes the most, so you can say that we are consumerists, we sometimes buy unnecessary things that we don't want or we don't need (...). Here we are practically living off imports, practically everything is imported, and now we are more consumerist, we buy ... every day we buy something.

ISELIN: And where does it come from, this need to buy something?

DAVID: It is not a need, sometimes it can be a need, depending on the point of view, but sometimes it is just a capricho (a whim) for having it. Here in Venezuela we have always lived, well, we still live something that is modernism, to give you an example, if I don't have this cap from a fashion brand, I don't feel well. And today, within society and above all in the barrios where you see this the most, among the youngsters, that if a youngster doesn't have clothes from a fashion brand they are not accepted by their groups and friends. That is where the mother also fails, because sometimes the mother abstains from buying necessary things for the home in order to buy unnecessary things for her children. So that is a problem that we also need to attack in today's youth and another thing as well, that today there are too many murders, for a telephone of a fashion brand, for a (inaudible) of a fashion brand, if we don't have purchasing power, for a capricho, we kill another person.

ISELIN: And from where and when do you think that this culture in Venezuela has come from?

DAVID: This is coming from decades ago, decades, decades, decades, that has been imprinted here by previous governments, as far as I know since Gómez and up till now ... the majority of the governments since then have been ... we have been invaded and acquired by capitalism, which is what we are fighting against today, and we are achieving this goal. Here, all the other governments have depended upon capitalism, we have been dominated by capitalism and today they are cataloguing the president as bad because he doesn't want to let himself be dominated by capitalism. We are neither going to let ourselves be dominated by capitalism because we have already woken up and saw reality, we woke up from this dream that had (inaudible) us ... now we are in a social dream, socialist, of justice and peace. 
Note that David attributes this cultural proclivity to spending to "modernism," which he directly associates with having name-brand clothes. Albeit a seemingly casual choice of words, it illustrates how modernity and symbols of global mass consumption were tied together in the popular imagery. David, who was pursuing a university degree in public administration, and who also had attended several courses in popular education, went on to immediately identify capitalism as the "culprit" for this national trait. This formulation illustrates how the template of "capitalism" within the Bolivarian discourse refers to a particular socio-cultural paradigm that the country has lived by for the greater part of the twentieth century. As he pointed out, Chávez was perceived as the first president who resisted this model of domination, setting Venezuelans on a new path toward social justice and peace-and at a confrontational path with the patrons of capitalist modernity.

\section{CONSUMERISM FROM WiTHIN}

The alluring power of conspicuous consumption constituted a source of deep preoccupation for many community activists. It was perceived as a form of "false consciousness" that made the popular sectors, now with a slightly better purchasing power, seek refuge in dreams of middle-class consumption and commodified Western identities instead of gaining consciousness about the cultural and political battle that the Bolivarian process constituted. Oscar, whom we recognize from the ordeal with the Community Hospital (CDI) in Chap. 5, was a particularly concerned interlocutor of this view. As a stern believer in poder popular and in the imperative of emancipation from cultural imperialism, he observed with great concern how people around him were drawn to dreams and practices of consumption. In one interview, he framed it this way:

OSCAR: Look, I will give you an example that concerns me and my daughter, I call her mamita, she is 10 years old. And we go for a walk in the park, or we are strolling, and she says to me, "Dad, I want to go to the shopping mall, the El Sambil, El Recreo." And I say to her: "But why will we go there?" My sister says that one goes there to glue your snot on the window displays of those large shopping malls ... those large shopping malls that are now all over the large cities like Caracas, Valencia, Maracaibo, Barquisimeto. So look, my daughter asks me to go there and these are some of the contradictions. 
And as she is a little girl, 10 years old, and I say to her but coño mamita, what are we going there for? "Well, to eat, to look." "But what are we going to look at?"

So having a shopping mall over there is to awake in her all this consumerism ... of buying this, of buying clothes, I ... I am a militant, I am a militant of revolutionary ideas, and these contradictions that I am hearing daily with my daughters, with my nieces and nephews, with my family, this is a debate that is going on daily ... and what do we do if where she is studying, in this school or in this sector where she lives sees these [values], what do we do? Because I cannot impose my ideas on her, rather, this is a constant process with her, to debate, to make her see the new values, or the values that I have (...).

Oscar was part of an old boy's colectivo in 23 de Enero, which for decades has been central in organizing cultural, sportive and social events in the community. They set themselves apart from many other colectivos in the community by their explicit non-militant style. Also, they were hesitant to tie themselves too closely to the new arenas for popular participation endorsed by the government. Rather, they considered popular struggle as essentially a process of bottom-up emancipation from both cultural and political modes of dominance and power. Consequently, Oscar and his comrades were deeply worried about many of the "vices" that continued to thrive within the Bolivarian movement, and the obstacles this posed for continuing political struggle beyond having a sympathetic government in power. He saw ideologies of consumptions as one of the most worrying signs of the limitations to the Bolivarian revolution as a process of deep socio-cultural change:

What can we do if there is this constant; the television, the internet, the mobile telephone in fashion. I mean, here people are saying that this is the country with the largest acquisition of new mobile telephones (smart phones) and in the communities, you get shocked how this is instilled in our young women, in your children, that the Christmas presents, from the Jesus Child ${ }^{2}$ in quotation marks, the arrival of these gifts from Christmas are telephones, they are giving a Blackberry to a child of seven, eight years .... What do we do then?

So look how society, how these big men have us subdued ... and they still have total dominance, that is without a doubt ... and besides, this is 
also one of the contradictions within our communities, in these processes of struggle that the communal councils are engaged in, that are taking place in the different community organizations, in sports, in culture, this debate or this diffusion of new ideas that is taking place. This is daily work, constant, at every hour...

Oscar's words are representative of how many people would conceptualize the paradox between the powerful template of consumption within the popular sectors and the simultaneous drive toward fomenting a new consciousness that was taking place in a variety of arenas. He found it puzzling and disturbing that many poor people seemed to prioritize buying consumer goods, at any cost, and that children were being pushed into a consumer culture through all media channels, supported by parents who failed to gain consciousness themselves. Indeed, a major concern of many activists was, above all, for young people, who were continuously induced into believing that "anything foreign" was way better than anything Venezuelan. All the brands that children and youths' culture revolved around were foreign: McDonalds, Kentucky Fried Chicken, Pizza Hut, Disney, Hello Kitty, Monster High, Hollywood blockbusters, Blackberry, Apple, Nike, Ralph Lauren, the list is endless.

The subject was also brought up in a conversation with Marta, a woman in her 30s originally of humble origins but now an accomplished singer. Over a cup of coffee by her mother's dining table in one of the low-rise apartment blocks in 23 de Enero, she spelled it out like this:

What is the most problematic about it? Ideologically we are still, we could say that the revolution is still in between the Fourth and the Fifth Republic ... the masses, el pueblo has really not imprinted, formed, what is socialism, this is why we are still living in the midst of capitalism. Chavismo, one of its principal traits I would say, is this love for the patria, the need for justice, that is why eight millions and something have voted for Chávez, because of this sense of nationalism that we had completely lost ... before the February $4,1992,{ }^{3}$ there wasn't this sense of patria, of nation .... Chavismo has this element which is what the esqualidos don't have, it doesn't interest them ... but what happens?

I am talking about the ideological element, the fight against consumerism, because certainly we have been able to break through these things and created a sense of patria, of national identification, of pride of being Venezuelan, of recognition, about what it means to be Bolivarian, where are we coming from, where are our roots, but still there are elements that are 
imprinted upon us, above all from the great enemy, what we have there in front of us, the media, Hollywood, we are trying to recuperate our national identity, but it is really difficult, really difficult, because our children still have Disney Channel—and I don't mean that Disney Channel is completely bad, but the problem is that we haven't managed, even with the educational processes at school, with the Canaimita, ${ }^{4}$ to make what is ours, our customs, our traditions, attractive to the younger generation...

Marta's way of expressing herself illustrates how the template of consumerism was tied to depreciating all things Venezuelan, a form of cultural imperialism undercutting the struggle for Third World political emancipation. Therefore, it was an important symbol of anti-consumerist nationalism when Chávez, in 2009, launched Venezuela's first domestically produced mobile telephone, the Vergatario, ${ }^{5}$ costing approximately 15 dollars. This was seen as an important confrontation with the power of cultural imperialism in Venezuela, and the telephone indeed quickly sold out, strategically launched by Chávez on live TV just before Mother's Day.

\section{SAMBIL SOCIETY}

A clearer picture is now emerging of how "consumerism" within Bolivarian discourse implied a broader set of signifiers describing Venezuelan history as a colonialized, transculturalized and socially segregated country. Consumerism became codified as the opposite of a people's history of Venezuela, of nationalist symbols, autochthonous traditions and national dignity. It was the child of the hegemonic globalization of the imagery of mass modernity "US style." Below is a text that eloquently captures this multi-layered interpretation of what consumerism represents, bringing out very clearly how it is socially and culturally codified within the current process of deep political polarization. The text, written as a poem and titled "What does it mean to be from Sambil society?" is a reference to the shopping mall chain Sambil, owned by the Venezuelan Cohen family, and probably the most potent symbol of consumer culture in Venezuela. Sambil Caracas is the third largest shopping mall in Venezuela. (The largest ones are in Isla Margarita and Maracay, which are among the largest in Latin America.) There are seven Sambil malls across Venezuela, in addition to one in Santo Domingo, the capital of the Dominican Republic, one in Curaçao, and one in Madrid (Sambil 2017).

Eighty thousand people a day visit Centro Comercial Sambil Chacao, in the center-east of Caracas (Informe21: 2013) It features two movie 
theaters, with a total of ten screens, a rooftop amusement park, a concert arena, a bowling alley, an arcade, a small aquarium and several food courts, with both international and national fast-food kiosks. It sells a range of international luxury brands, and has spin-off initiatives, such as a beauty contest and its own magazine. The chain also organizes group weddings in the month of February (cashing in on Valentine's Day) as a way to "demonstrate its compromise with the Venezuelan society" and in order to "promote and consolidate moral values in the Venezuelan society" (Notiactual 2011, author's translation from Spanish). Sambil arranges fashion shows, holds cooking classes for housewives, sponsors schools and sport facilities, organizes fundraising events and aerobic classes.

I am mentioning these details to underline that Sambil is more than a mall in Venezuela; it is a cultural symbol. The exact origin of the phrase Sociedad Sambil (Sambil Society, alluding to civil society) is uncertain, but it was famously used by the now-deceased popular revolutionary leader Lina Ron, founder and president of the party Unión Popular Venezolana (UPV). This twist of words elegantly captures how Sambil has come to epitomize a lifestyle, an attitude and an imagined class community. An article was later posted on the pro-government activist website www. apporea.org, entitled "What does it mean to be from Sambil society?" (Silva 2005). I will quote it in full here, because its extremely rich cultural references illustrates how templates of consumption, class and politics play into the deeper cultural-political struggles taking place between contrasting and contradictory worldviews.

What does it mean to be from the Sambil Society?

It is to live for consumption and not to consume in order to live, that is, to pass by your house and live in Sambil, not to live in your house and pass by Sambil.

It is to be an innocent victim of the dictatorship of the media of incommunication (sic), which from childhood on teaches one to live from appearance and not from essence.

It is to ridicule social sensibility that people with fortunes feel towards "the wretched of the earth" (Frantz Fanon).

It is to talk negatively about Venezuela and her people while drinking whisky in a bar in Las Mercedes (and the most fortunate ones in London), and when they meet for a business lunch in Altamira (idem in Paris).

It is to blame the Venezuelan people suffering in poverty for being lazy and irresponsible when it is these people who produce goods and riches for those parasites and for the gringo empire that they admire so deeply. 
It is to prefer to read Seventeen magazine instead of a book about Venezuelan history.

It is to know all the gossip from the parties in high society and beauty contests, and to ignore the socio-historical formation of Venezuela as a nation.

It is to discriminate against someone who doesn't have a luxury car or brand clothes like they have.

It is to imitate foreign fashion promoted on television, and to despise as monkeys and marginals the creole traditions and customs.

It is to dress the mind with T-shirts of Backstreet Boys and Britney Spears, and to look ugly upon those who dress their body in T-shirts of Ali Primera and Simón Bolívar. In a few words, it is to speak Spanish and think in English.

It is to feel pain for the dead North Americans in the World Trade Center in New York, and not feel anything for our dead Latino brothers in the Chorillos neighborhood when the United States invaded Panama.

It is to criticize with "squalid" hysteria the destruction of the statue of Christopher Columbus as an act of the marginal hordes of the circles of terror, and not to say anything about the civic pacific pull down of the statue of Cacique Guacaipuro in Los Teques when they did the guarimbas. ${ }^{6}$

It is to settle with being the pupil of a big high school when one should be a student at the university, and to graduate in order to serve an exploiter with the purpose of becoming like him, without caring about whether his work harms or benefits the people who paid for the existence of the very university.

It is to make tremendous fuss for knowing that there are students who don't eat at McDonald's or cannot pay for books, which is why they propose that each human right (like the right to education, to life or to freedom of expression) should be paid by those who have the most, and make it available at a low cost to the poor students (and not give it for free ... zero paternalism for the tierrúos (dirty poor) according to papa's boys), all based on a socio-economic study that converts the human rights of all (which should be free!) into a privilege for the few (who can pay).

It is to be an adulador rastacuero (sycophant ass-kisser) to a decadent and opportunist aristocrat professor, and to join him in scorning other members of the university community for their academic conditions, their social origin and their racial characteristics.

It is to call themselves civil society when they protest, and to call the poor hordes and mobs when they do the same.

It is to protest comfortably from their luxurious balcony putting on a CD with pot-banging ${ }^{7}$ to not get their delicate skin sweaty.

It is to be in favor of Chávez if he had been white and with blue eyes, and had talked in an abstract and technical language in order to be a hypocrite like them, instead of making objective and constructive criticism. 
It is to die from hunger in a shack on the shantytown hills, while thinking and wanting to be like them!!!!

In this text, Sambil Society takes on multiple meanings: of class resentments, of anti-nationalism, of lack of sense of patria and sense of social consciousness, of adulation for anything foreign, anything with superficial status, anything that represents the opposite of the values that the Bolivarian process - through its ideological thirdworldism outlook and class rooting-represents. Sambil Society implies to be a snob and a hypocrite. The very term "Sambil Society" refers to the ways in which, as is also described in the poem, the middle and upper classes call themselves civil society, whereas Chavista supporters are referred to as hordes and mobs. This is a point that is often underscored by Chavistas because, to them, it illustrates the global dimension of Venezuelan class conflicts; they interpret "civil society" as an ideological concept embracing a particular socio-economic group of global citizens (see also Chatterjee 2004 for an analysis of its historical origins and its colonial adaption). From the point of view of the popular sectors, the concept "civil society" is monopolized by the opposition and actively used as a worldwide marketing strategy in order to gain support for its cause, legitimizing oppositional and middleclass political agency while negating popular and pro-government agency.

It is however important to note that Sambil Society is not merely ascribed to class. Rather, the last line, "It is to die from hunger in a shack on the shantytown hills, while thinking and acting like them!" refers to poor people who try to associate with middle-class culture through consumption. They are often colloquially referred to as sifrinos. Bourdieu teased out the ways in which class mobility is conditioned by habitus-a lower-class person can aspire to social mobility through simulating upperclass aesthetic dispositions, but this person will be exposed by the incapability of assuming (embodying) the finer details of that higher-class habitus (Bourdieu 1979). Grounded in a similar popular understanding of social mobility and symbolic capital, many "vanguard revolutionaries" viewed sifrinos with a mix of pity and contempt. In embracing middle-class identity markers (sociolect, consumption symbols, talking in a denigrating manner about poor people and popular culture, using a scornful middleclass discourse about Chávez and the government, being "snobbish") they are performing an act of "class betrayal." Yet, they will never be able to "become middle-class" and be fully socially accepted by the middle class, no matter how hard they try. 


\section{Reappreciating the National-Popular}

As the text "What does it mean to be from Sambil Society?" illustrates, imageries and discourses of consumption tie up with the broader politicalcultural process of carving out a new sense of nationalism and national dignity. Central to this process is a rejection of the symbols of Western consumer capitalism and a revaluation of what is perceived as the "authentic" and "autochthonous" Venezuela.

The latter is, in popular and political discourses, often represented by national traditions and costumes like folkloric and popular music, Venezuelan traditional food (some stereotyped binaries: arepa instead of bread, pabellón criollo instead of McDonald's, papillón con limón instead of coke, hallaca instead of Christmas turkey), watching Venezuelan movies instead of the latest Hollywood blockbusters, going on vacation in Venezuela instead of going abroad, appreciating traditional folkloric dances and African drums rather than Western commercial music.

Rosa, a woman in her 60s from Propatria, recalled how it used to be "shameful" to listen to popular and folkloric music even in the barrios; it was considered backward and not fashionable. Instead of letting the music blast from open windows, as they usually did, they would listen to it behind closed doors. Whether this is true I don't know, but the fact that she recalls it this way illustrates how the "traditional Venezuela" was devaluated even in popular imagination.

\section{Counter-Cultures}

Fernandes (2010) argues that cultural identities in Venezuela under Chavez "provided an idiom for the expression of class and racial cleavages in an emerging battleground between multiple competing tendencies in Venezuelan society" (Fernandes 2010:114). In a similar vein I would suggest that the attempt to create a counter-culture to the global consumer culture by emphasizing traditional, popular and national symbols, values and commodities represents an idiom for articulating the broader culturalpolitical struggle that the Bolivarian process represented. Consumerismin its capacity of being global capitalism's seductive hoax and the prime signifier of bourgeois and elite identity—symbolizes the opposite of assuming a political consciousness and revolutionary agenda, thereby becoming a prime signifier within this ideological scheme.

However, one must be careful to interpret these dual schemes as contrasting and distinct "identity-imageries": one espousing Western moder- 
nity through consumption, and the other espousing anti-consumerist autochthonous, nationalist development. Rather, repertoires of meaning, cultural idioms and social formations shaping "consumer identities" in various guises in Venezuela are embedded in broader processes of identity formation and cultural-political symbolisms and ideologies. Members of different social and political groups are appropriating heterogeneous repertoires of goods and messages circulating within global circuits as well as in specific localities. Moreover, what constitutes "autochthonous Venezuelan culture" is evidently not a definite bundle of practices and tradition that is set in stone. In Venezuela, as in any other locality, what is espoused as an expression of "cultural authenticity" is malleable, vexing and open to both the invention and reinvention of tradition (Hobsbawm and Ranger 1992).

It is therefore important to underscore that rather than creating two binary "cultures" as if they were true reflections of binary identity constructs or "real" binary opposites, my intention here has been to illustrate how this schism is ideologically articulated within the dominant Bolivarian discourse. It reflects the political polarization in the country revolving around the construction of opposites: pro-government-opposition, pro-Venezuelapro-imperialism, pro-nation-pro-USA, pro-Socialism for the twenty-first century-pro-capitalism, pro-poor-pro-bourgeois. Within these opposites, "consumerism" emerged as a key symbolic marker expressing different cultural-political identities, imagined communities and moral economies.

This chapter started out with the observation of how "money" seemed to constitute a dense social signifier in Bolivarian discourse and social imaginaries, forming part of a broader narrative of a bundle of social vices that had been installed in society since long back. Consequently, I linked this to a theoretical and empirical exploration of how we may ground emic conceptualizations and social critique of "capitalism" and "neoliberalism" to the ways in which these macro-processes were imprinted in people's real lives. Furthermore, we discussed how stereotyped class and political identities were crafted around notions of cultural and material consumption drawing on distinctions between "autochthonous" culture and Western modernity. In Chap. 9, we will continue our exploration of contrasting, contradictory and symbol-laden notions of oil wealth and consumption. However, this time, our ethnographic focus is not conspicuous consumption, but the ways in which collective consumption through state distribution unfolded in the midst of the Bolivarian process. 


\section{Notes}

1. Though many die because they cannot afford to do it in proper clinics (see World Observer Online 2013).

2. Venezuelan children get their Christmas presents at midnight on the night of 24 December, and they are told that the presents are brought by the Jesus Child.

3. This is the date of the Chávez-led attempt to overthrow the Perez government; see Chap. 2.

4. Canaimita is a Venezuelan-assembled mini-computer that is handed out for free to children in public schools, produced based on an agreement with China.

5. The name itself caused a bit of controversy. Vergatario is a slang word for excellent, superb or optimal, but it is also a vulgar reference to penis.

6. This line deserves some explanation. On October 12, 2004, a statue of Christopher Columbus was torn down in Caracas in protest against the celebration of the discovery of the Americas. October 12 has previously been celebrated as a national holiday, named Día de la Raza (day of the races). In Venezuela, this day has been re-baptized as Dia de Resistencia Indígena (day of indigenous resistance). The destruction of the statue was heavily criticized by the opposition who termed it an act of Chávez's "hordes" and the Bolivarian Circles, who are commonly referred to as circles of terror in opposition media (see Chap. 5). On the other hand, Cacique Guacaipuro was an Indian tribal leader who led the resistance against the invasion of the Spaniards. His statue was brought down by opposition marchers during the guarimbas in 2004-guarimbas refers to street riots which were put in motion by the opposition with the purpose of inciting a civil uprising.

7. To bang pots and pans against each other is a common form of public protest in Latin America, predominantly among the middle classes.

\section{BIBLIOGRAPHY}

Appadurai, Arjun. 1988. The Social Life of Things. Commodities in Cultural Perspective. Cambridge: Cambridge University Press.

Apter, Andrew. 1993. "Festac for Black People": Oil Capitalism and the Spectacle of Culture in Nigeria. Paper delivered at the Presenting the Past Workshop, Northwestern University, Evanston, April 16.

Arnett, Peter. 1978. Oil Boom-Town. Conspicuous Consumption on a Grand Scale. The News and Courier, May 21. http://news.google.com/newspapers?n $\mathrm{id}=2506 \& \mathrm{dat}=19780521 \& \mathrm{id}=\mathrm{w} 51$ JAAAAIBAJ $\&$ sjid $=$ fgwNAAAAIBAJ \&pg $=1422,4549248$. Accessed January 2, 2014.

Bourdieu, Pierre. 1979. Distinctions. A Social Critique of the Judgment of Taste. Cambridge, MA: Harvard University Press. 
Chatterjee, Partha. 2004. The Politics of the Governed. Reflections on Popular Politics in Most of the World. New York: Colombia University Press.

Comaroff, Jean, and John L. Comaroff. 1987. The Madman and the Migrant: Work and Labor in the Historical Consciousness of a South African People. American Ethnologist 14 (2): 191-209.

- 1999. Occult Economies and the Violence of Abstraction: Notes from the South African Postcolony. American Ethnologist 26 (2): 279-303.

- 2001. Naturing the Nation: Aliens, Apocalypse and the Postcolonial State. Journal of Southern African Studies 27 (3): 627-651.

Coronil, Fernando. 1997. The Magical State: Nature, Money, and Modernity in Venezuela. Chicago: University of Chicago Press.

- 2008. Chávez's Venezuela. A New Magical State? In ReVista. Harvard Review of Latin America, vol. 8. Cambridge, MA: David Rockefeller Center for Latin American Studies, Harvard University.

Debord, Guy. 1967. The Society of the Spectacle. New York: Zone Books.

Douglas, Mary, and Baron Isherwood. 1996. The World of Goods. Towards an Anthropology of Consumption. London and New York: Routledge.

Englund, Harri, and James Leach. 2000. Ethnography and the Meta-Narrative of Modernity. Current Anthropology 41 (2): 225-248.

Ewell, Judith. 1984. Venezuela. A Century of Change. London: C. Hurst \& Company.

Fernandes, Sujatha. 2010. Who Can Stop the Drums? Urban Social Movements in Chávez’ Venezuela. Durham and London: Duke University Press.

Fourcade, Marion, and Kieran Healy. 2007. Moral Views on Market Society. Annual Review of Sociology 33: 285-311.

Friedman, Jonathan. 1994. Consumption and Identity. London and New York: Routledge.

Gledhill, John. 1995. Neoliberalism, Transnationalization and Rural Poverty: A Case Study of Michoacan, Mexico. Boulder: Westview Press.

- 2004. Neoliberalism. In A Companion to the Anthropology of Politics, ed. D. Nugent and J. Vincent. Malden, MA: Blackwell Publishing.

Graeber, David. 2011. Consumption. Current Anthropology 52 (4): 489-511.

Guevara, Ernesto Che. 2003 [1965]. Socialism and Man in Cuba. In Che Guevara Reader. Writings on Politics and Revolution, ed. D. Deutchman. Melbourne and New York: Ocean Press.

Harvey, David. 2005. A Brief History of Neoliberalism. Oxford: Oxford University Press.

Hillman, Richard. 1994. Democracy for the Privileged. Crisis and Transition in Venezuela. Boulder and London: Lynne Rienner Publishers.

Hobsbawm, Eric, and Terence O. Ranger. 1992. The Invention of Tradition. Cambridge: Cambridge University Press.

Hoffman, Kelly, and Miguel Angel Centeno. 2003. The Lopsided Continent: Inequality in Latin America. Annual Review of Sociology 29: 363-390. 
Howell, Signe. 1997. Introduction. In The Ethnography of Moralities, ed. S. Howell. London and New York: Routledge.

Informe21. 2013. Venezuela: El consumismo versus socialismo del siglo XXI. http:// informe21.com/elecciones-presidenciales/venezuela-el-consumismo-versussocialismo-del-siglo-xxi. Accessed February 20, 2017.

Jackson, Peter. 1999. Commodity Cultures: The Traffic in Things. Transactions of the Institute of British Geographers 24 (1): 95-108.

- 2004. Local Consumption Cultures in a Globalizing World. Transactions of the Institute of British Geographers 29 (2): 165-178.

Karl, Terry Lynn. 1997. The Paradox of Plenty. Oil Booms and Petro-States. Berkeley: University of California Press.

- 1999. The Perils of the Petro-State: Reflections on the Paradox of Plenty. Journal of International Affairs 53 (1): 31-48.

Lander, Edgardo. 2005. Venezuelan Social Conflict in a Global Context. Latin American Perspectives 32 (2): 20-38.

McGregor, Sue. 2002. Consumer Citizenship: A Pathway to Sustainable Development? Keynote speech delivered at the International Conference on Developing Consumer Citizenship, Hamar, Norway, April n.d. http://www.consultmcgregor. com/documents/keynotes/norway_keynote.pdf. Accessed February 20, 2017.

Miles, Steven. 1998. Consumerism as a Way of Life. London: Sage.

Mullins, Paul R. 2011. The Archaeology of Consumer Culture. Gainesville: University Press of Florida.

Notiactual. 2011. Todos los centros Sambil de Venezuela celebrarán bodas colectivas el próximo 14 de febrero. Notiactual, January 13. http://www.notiactual. com/todos-los-centros-sambil-de-venezuela-celebraran-bodas-colectivas-elproximo-14-de-febrero/. Accessed February 20, 2017.

Nugent, David. 1996. From Devil Pacts to Drug Deals: Commerce, Unnatural Accumulation, and Moral Community in "Modern" Peru. American Ethnologist 23 (2): 258-290.

Ortner, Sherry B. 2016. Dark Anthropology and Its Others. HAU: Journal of Ethnographic Theory 6 (1): 47-73.

Sætre, Simen. 2009. Petromania. Oslo: J.M. Stenersens Forlag AS.

Salas, Miguel Tinker. 2009. The Enduring Legacy. Oil, Culture, and Society in Venezuela. Durham and London: Duke University Press.

Sambil. 2017. http://tusambil.com

Sandel, Michael. 1998. What Money Can't Buy: The Moral Limits of the Market. Speech delivered at the Tanner Lectures on Human Values, Brasenose College, Oxford, May 11-12.

Silva, Emilio. 2005. Qué es ser de la Sociedad Sambil? Aporrea, June 2. http:// www.aporrea.org/actualidad/al3751.html. Accessed February 20, 2017.

Slater, Don. 1997. Consumer Culture and Modernity. Cambridge: Polity Press.

Taussig, Michael. 1977. The Genesis of Capitalism amongst a South American Peasantry: Devil's Labor and the Baptism of Money. Comparative Studies in Society and History 19 (2): 130-155. 
1980. The Devil and Commodity Fetishism in Latin America. Chapel Hill: The University of North Carolina Press.

Walsh, Andrew. 2003. "Hot Money" and Daring Consumption in a Northern Malagasy Sapphire-Mining Town. American Ethnologist 30 (2): 290-305.

Watts, Michael. 1999. Petro-Violence: Some Thoughts on Community, Extraction, and Political Ecology. Working Paper 99-1, Institute of International Studies, University of California, Berkeley.

- 2004. Anatomies of Community: Some Thoughts on Geography, Resources and Empire. Transactions of the Institute of British Geographers 29 (2): 195-216.

Weyland, Kurt. 2004. Neoliberalism and Democracy in Latin America: A Mixed Record. Latin American Politics and Society 46 (1): 135-157.

World Observer Online. 2013. 'It Hurts So Much I Can't Sit Down': The Dangerous Practice of Butt Implants That Is Ruining Women's Lives across Venezuela. World Observer Online, November 16. http://worldobserveronline. com/2013/11/16/hurts-much-cant-sit-dangerous-practice-butt-implantsruining-womens-lives-across-venezuela/. Accessed February 20, 2017.

\section{Audiovisuals}

1980. The Gods Must Be Crazy. Dir. Jamie Uys. South Africa: CAT Films/Mimosa Films.

2007. The People and the President. A Portrait of the Bolivarian Revolution. Dir. Iselin Strønen and Hildegunn Wrrness. Bergen, Norway: Geriljastil Productions.

Open Access This chapter is distributed under the terms of the Creative Commons Attribution 4.0 International License (http://creativecommons.org/ licenses/by/4.0/), which permits use, duplication, adaptation, distribution and reproduction in any medium or format, as long as you give appropriate credit to the original author(s) and the source, provide a link to the Creative Commons license and indicate if changes were made.

The images or other third party material in this chapter are included in the chapter's Creative Commons license, unless indicated otherwise in a credit line to the material. If material is not included in the chapter's Creative Commons license and your intended use is not permitted by statutory regulation or exceeds the permitted use, you will need to obtain permission directly from the copyright holder.

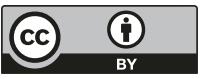




\section{Collective Consumption and the Wealthy Nation-State}

The state of Vargas, spring 2011: The area was unrecognizable from the last time I passed through here. The coastline west of the international airport of Maiquetía, in the state of Vargas, used to be a dusty shantytown area with a dimly lit road cutting through the lines of brick houses and shacks. Children used to play half-naked on the side of the road while their mothers were sitting on chairs outside their houses yelling to their kids as the cars and motorbikes rushed through. The men used to stand in clusters, talking and drinking beer and cheap liquor, or around a car or motorbike talking in men's manly and competitive manner. The hot, humid, salty air from the Atlantic Ocean, 300 meters away, was corrugating everything: the roofs, the bricks, facial skin, the energy to do anything. Behind the last line of houses, a half-built road was lying in the dark. Behind the road was a muddy, unlit beach.

Now, everything had changed. Two long rows of freshly painted yellow apartment buildings were facing the Atlantic Ocean. A sign announced to the visitors that the community's name was Mares Abajo. A newly constructed highway ran in front of the buildings. On the other side of the road was a recreational area, complete with a children's playground and wooden beach tents. A sign welcomed the visitors to Playa Surfista (surfer's beach) and another sign announced that this was a recreational area and that it was forbidden to sell or drink liquors. The shantytown area and the dusty road cutting through it had been demolished; only some smaller clusters of brick houses were left on the side of the apartment buildings. 
We took off from the highway and drove into the plaza between one of the apartment buildings' clusters. It was clean and spacey and the cars were neatly lined up along the pavement. Children were running around with their bicycles. A group of adults had taken out chairs and a table, where a domino game was set up.

Together with a friend I had come to visit Abigayl and Ramón, friends from a long time back. They used to live with a family so large that I was never able to keep track of all its members, all cramped together in one of the makeshift brick shacks that had now been demolished. The "bathroom" was a wooden shack with a defective toilet and a bucket to wash it with.

Four months back, they had moved into the new apartment. It had two bedrooms, a bathroom with shower and a combined living room and kitchen. The apartment buildings were part of Gran Misión Vivienda Venezuela, a massive housing project launched by Chávez in 2010. They hadn't paid for the apartment. As they were very low on the income scale, it was handed to them for free. Abigayl and Ramón had two small sons together, nicknamed El Chino (the Chinese) and el Ruso (the Russian). Another son, the eldest, had died when a toddler as a result of brain damage caused by a hospital error during delivery. He suffered from convulsions until he eventually died. They never got a real explanation, proper treatment or an apology from the hospital. Abigayl always got a profoundly sad expression when this topic came up. Her lined face and skinny body were marked by a hard life, and shadows of grief often moved through her sparkly, friendly eyes.

Abigayl and Ramón were examples of people who had had their lives transformed in small, but significant steps during the past decade. Ramón was a short, skinny man in his 40 s with a restless energy. He talked quickly, moved quickly and smoked quickly, and when he started to drink beer or anis, which he frequently used to do, he drank quickly too. He would probably have been diagnosed with ADHD if he had ever in his life been in contact with a school psychiatrist who cared. Of course, when he went to school, such a thing didn't exist. Ramón made a living as a construction worker, or as a truck driver or as a mechanic. He had no professional education, but in front of any engine with tools in hand, he was a wizard. Some years back, Ramón went to Cuba as a part of Frente Fransisco de Miranda. He was inspired by his brother, who lived in Caracas and was deeply involved in the political movement that the Frente constituted at the time. Ramón enjoyed the stay in Cuba. Once back in Caracas, he collaborated with the Frente the best way he knew-driving and main- 
taining their cars. He participated in perhaps the most intense part of the revolution, the years after the coup in 2002-2003, when thousands of young people roamed the country setting up health stations, identifying the needs of poor communities, visiting the most remote corners of the country to give identity papers to people who had lived their whole lives as undocumented citizens.

Ramón will never be an intellectual. He will never be an ideologue. He wasn't very fond of the classes in political economy and history that they had in Cuba, he confided. In fact, I suspected that his literacy skills were at minimum level. But through the Frente, he got a political identity, social and political companionship, a sense of belonging. From his guts, if not from a coherent ideological set of ideas, he contributed to the political processes Venezuela was experiencing. He had even participated in constructing the apartment buildings they were now living in as well as the highway that ran past them.

Even though Ramón and Abigayl had only moved some 100 meters away from where their old shack used to be, they had in reality taken a step into a completely different life. To live in an apartment and to live in a rancho was for them worlds apart. And it was as if both of them had changed. I couldn't point to exactly what, but they had a new air to them, a new way of talking, as if their new physical surroundings had become imprinted in their bodies, into their way of moving. The apartment was scarcely furnished, and the furniture that they had was old and shabby. The water supply in the apartments was unstable as the work on the underground tanks that would supply the apartments had not been finished. Yet, they both felt that they had started a new chapter in life. Abigayl told me that she was about to start night classes with Misión Ribas in order to complete high school. After that, she wanted to study social work. Ramón continued finding employment in the construction sectors, in the other apartment projects that were under way in the area. El Chino and el Ruso, who were racing around the apartment on two small bikes, nodded when I asked them if they liked their new home.

Ramón in particular seemed calmer. He was standing outside on the narrow French balcony, pointing down to the plaza between the two apartment blocks that were facing each other. "We are all good neighbors," he said. "We meet down in the patio to play domino and talk, but there aren't any problems here, and besides, there are several policemen living here." He also confided that he drank less now. He just drank some beer when he played domino down in the plaza, but other than that he just worked as much as he could. 


\section{Repaying the DebT}

The story about the transformation of Ramón's and Abigayl's lives reminds us of a fundamental aspect of the Bolivarian process; namely, that throughout the years of the Chávez government, millions of poor people saw their lives improve. They were better fed; were better schooled; acquired better housing, received free healthcare, wheel chairs, vaccinations, university scholarships, single mother scholarships, and pensions; and participated in sports programs and cultural education. According to ECLAC, the United Nations Economic Commission on Latin America and the Caribbean, income-based poverty rates fell from 48.6 percent of the population in 2002 to 27.8 percent of the population in 2010 (Tinker Salas 2015:192). Per the National Statistics Institute, overall poverty levels fell from 55.6 percent in 1998 to 21.2 percent in 2012. Extreme poverty dropped from 25.5 percent in 1998 to 6 percent in $2012 .{ }^{1}$ In addition, there were significant welfare improvements not captured through income-based statistical methods (Weisbrot and Sandoval 2007). In a UN-Habitat report from 2012, Venezuela was ranked with a Gini index of 0.41 , the best score in Latin America (the lowest level of economic inequalities). This is a significant improvement compared to the 1990s (UN-Habitat 2012). ${ }^{2}$

During my time in the barrios in the Chávez era, people responded rather univocally that they had never before had such access to social welfare (though it was by no means perfect). Indeed, people's subjective assessment of the situation for themselves as well as their peers was that not only was poverty reduced and social services more available, but also that they enjoyed increased access to different arenas and venues for self-development, being it through education, community media, sports, culture or work programs. I met numerous people who expressed that their lives significantly changed for the better through the government's policies. To present a few examples: one was my neighbor in 23 de Enero, a slim, nervous single mother of three, constantly biting her teeth. She was a beneficiary of Misión Madres de Barrio (Mothers from the Barrio), through which she had gotten a small scholarship while following courses and other requirements that the program demanded. She told me with pride about when she resigned her scholarship from the government and signed a contract with Metro de Caracas. For the first time in her life, she had a job with pension benefits and cestatickets. ${ }^{3}$

Another one was a young girl who was severely physically dysfunctional because of a rheumatic condition, presumably because of an untreated 
virus infection when she was a child. Her condition was irreversible, and the doctors who originally treated her said that she was bound to end totally crippled in bed. It could perhaps be halted through operations, medication and physiotherapy, but it would require intense follow-up, which the family was not able to pay for through private medical insurance. At the time, public health was also in shambles, and it required a lot of payment on the side. In the early years of the Bolivarian process, her family sought out help through the Cuba-Venezuela health program. The girl was sent to Cuba several times together with her mother, all expenses paid for. The longest stay lasted for three months. Today, the accentuation of her condition has been halted. Two years ago, she graduated as a lawyer at the Bolivarian University (Universidad Bolivariana).

Another example is the numerous elderly people who underwent free surgeries for cataracts and similar conditions. This is a quick and relatively cheap procedure, but it had been out of reach for numerous people in the barrios. Through the so-called Misión Milagro set up by the Chávez government, 676,790 people had undergone eye surgery by 2012 (Correo del Orinoco 2012). One of them was Elizabeth, who lived together with her sons, their girlfriends and her grandchildren in a barrio in Catia. She had slowly lost her eyesight over several years, and when I first met, her vision was so bad that she did not dare to leave her house. After the operation, it was as if she could resume her life all over again.

Another example, again of which there are many, is the numerous people, above all women, who went back to school through the government's educational missions. One was my neighbor in Propatria, a dark-skinned, slim woman in her fifties. Her seven children, whom she had raised alone, were grown-ups (and one was dead). After having completed high school through Misión Ribas (high school level educational program), she was now studying comunicación social (journalism) through Mision Sucre (university level educational program). She, as many others middle-aged beneficiaries of the educational missions I spoke to, expressed that going back to school above all meant an increase in self-respect and a new sense of purpose. As many worded it, "it has opened our eyes."

Another example is the numerous people who were able to upgrade their homes. In the context of housing projects, the phrase recurrently used was to have a vivienda digna (a dignified home). Over the years, I have visited countless barrio homes. While some are quite comfortable, others live in substandard and even dangerous conditions. In one home I visited, one of the walls was completely covered with mold, producing 
a nauseating smell and tickling sensation that made me instinctively want to run out. A whole family lived and slept in this room, including children. Their grandmother had recently died from a respiratory disease. Another home was flooded every time it rained, damaging their belongings and furniture. The children had become traumatized and started crying and screaming that they had to move their things out every time rain started. In innumerable homes, people shower and go to the toilet behind a curtain or an old sheet in the absence of a door. In most barrio homes, people share beds and bedrooms, and often they cook, sleep and spend their time in the same room. People may spend years and decade improving their homes, slowly saving up money to add an extra room or construct a proper bathroom. The housing rehabilitation (or relocation) projects therefore represented a giant leap for many people in terms of living conditions, but also for their sense of dignity.

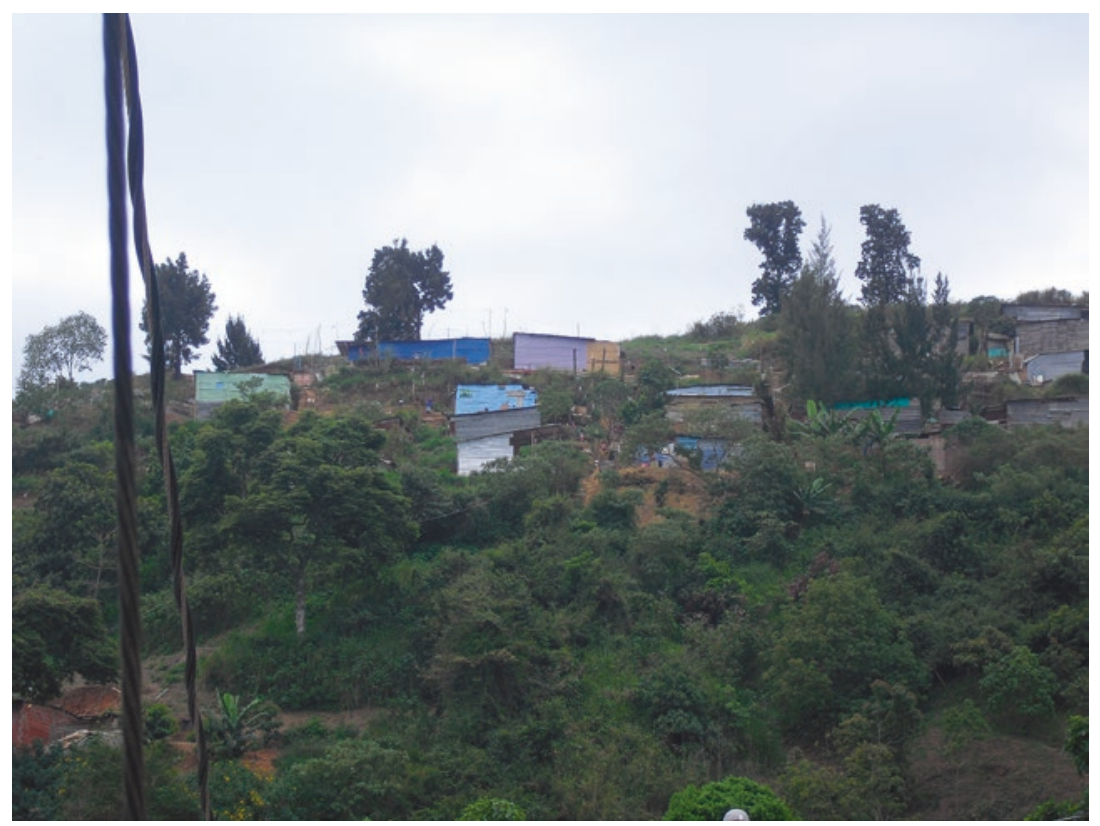

Photo 9.1 Ranchos in Casaalta 4, according to local residents built in unstable soil. Photo by the author 


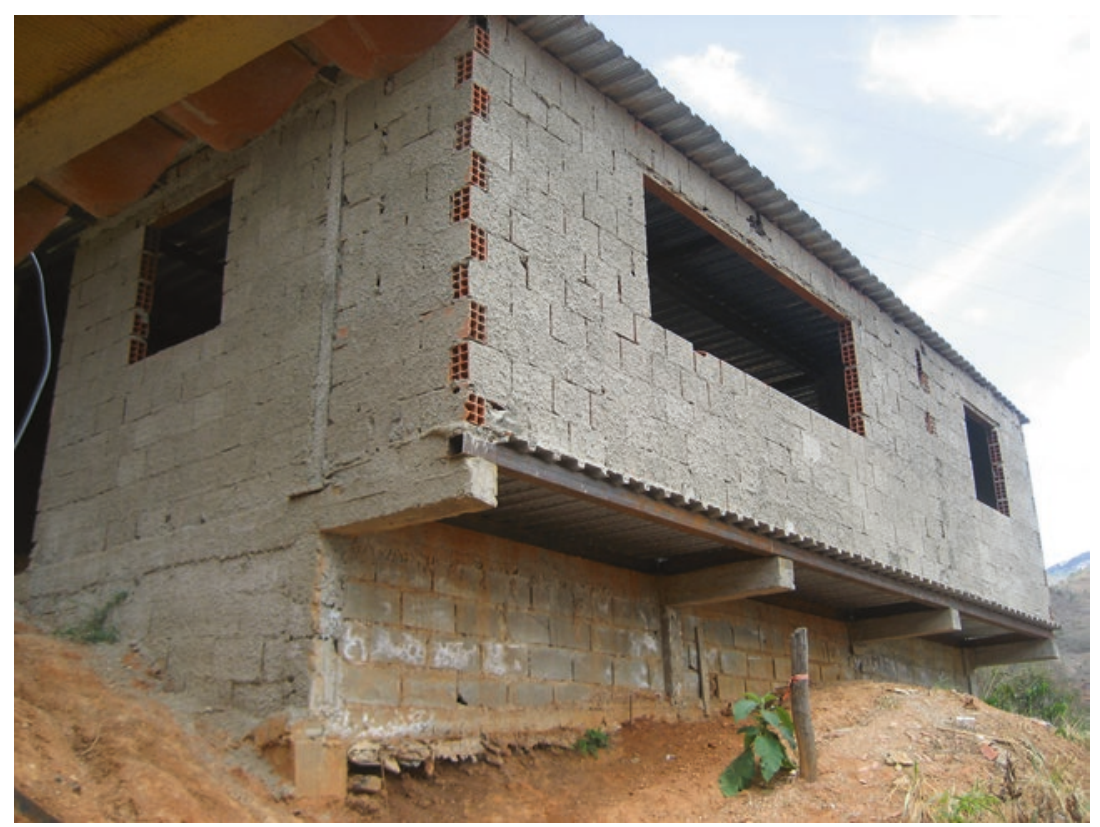

Photo 9.2 New home built through a communal council housing project. This kind of project is referred to as sustitución de ranchos por casas (substitution of ranchos (shacks) for homes). Photo by the author

I am emphasizing these histories for two reasons: one is in order to highlight the subjective experiences of poverty reduction, welfare improvements and improved life opportunities that undercut people's embrace of the Chávez government's pro-poor policies. Another is to provide a preamble for the ensuing discussion about the contradictions and paradoxes surrounding the use of oil revenues for collective consumption. Because all these social policies cost money. State money. Oil money. The social justice ethos of the Bolivarian process hinged on the promise of repaying the state's social debt to the poor. In an attempt to reverse a process of decades of accumulated poverty, neglect and marginalization, enormous sums of money-no one really knows how much-were channeled into public programs of various kinds: some by the public ministries, some through the executive's discretionary budgets, some through the state oil company, PDVSA. This significantly reshaped how people thought of oil 


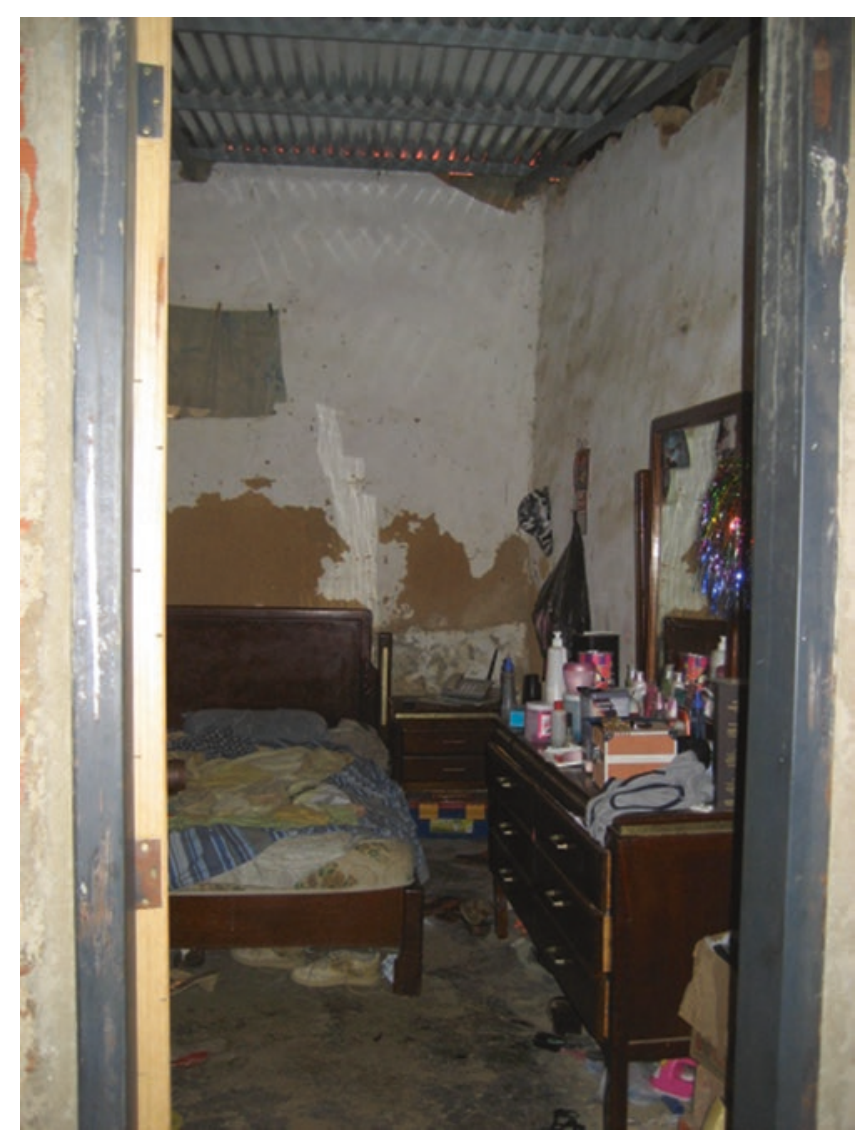

Photo 9.3 New roof acquired through a communal council project. Photo by the author

and national wealth, creating a sense of collective entitlement epitomized by the government slogans "Venezuela is now for everyone" and "PDVSA is now for everyone." A narrative about how the country's elites previously monopolized the nation's wealth contrasted this transfiguration of the relationship between public wealth and the popular sectors. Manuel, a bearded man in his 60 s from 23 de Enero put it this way:

Just have a look around to see how he has changed Venezuela. Everything he has done for the poor. Chávez has never given anything to me, but I look around, and I see how many people have benefited. Before, Venezuela was 


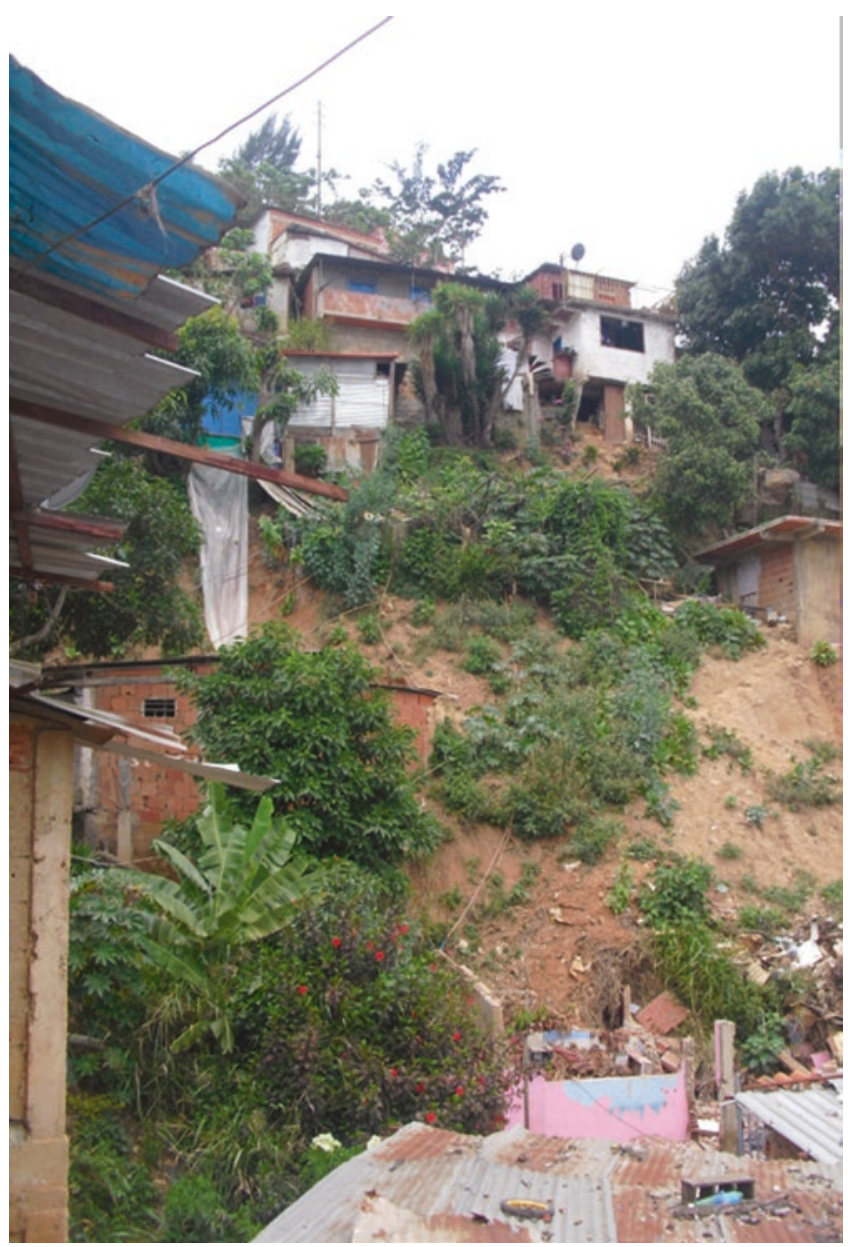

Photo 9.4 Barrio homes in el Nazareno. Photo by the author

run by three families. The Cicneros, the Zulvaga and the Phelps. It is in their nature to oppose Chávez because he runs against their interests. I accept that they oppose him. It is in their nature. But look how much this government is spending on the poor and still there is money left!!

At this point he was raising his voice before he finished: "And then imagine how much they took for themselves before, when they didn't share with the poor!" 


\section{The People's Oil}

Oil is at the center of popular imaginaries of the state in various Latin American countries, not only in Venezuela. Drawing the linkages between persistent accumulated marginalization-shaped by class and race-and elite rent capturing, claims for participating in the country's wealth, through state redistribution, loom large in struggles from below. As Gledhill has argued, these processes, and the imaginaries that they have fostered, are a reflection of how the neoliberal paradigm has been absorbed in Latin America:

In the case of the imaginary of "the people's oil," loss of sovereignty over resources is symptomatic of the abandonment of any "national project" by neoliberal regimes seeking to deepen the "opening" of national economies at any cost. (Gledhill 2008:59)

This is why "resource nationalism" and popular claims for redistribution go hand in hand. As resources are privatized in the collusion between national elites and foreign interests, "the privatizers are seen as alienating what should be public goods in their personal interest as well as 'selling the patrimony of the nation' to foreign interest" (Gledhill 2008:59). As he notes, the resistance to these policies is immediately derived from the direct consequences that they have in people's lives as the everyday costs of household reproduction increase (Gledhill 2008:59).

The Bolivarian discourse clearly articulated the interconnectedness of these political processes. Social justice was framed as state-led redistribution of their common patrimony, that is, oil rents. In contrast, "capitalism" or alternatively "neoliberalism" implied the unequal distribution of wealth through elite capturing and lack of redistribute measures. As Miche, the government worker from Fundacomunal, worded it:

Well, the concept of oil has changed, because before the oil was for los petroleros (the oil people), or to put it this way, we knew that the country was a super power in oil, but the very same politics of bread and circus for el pueblo made it so that we were satisfied with the little that they supposedly gave us while they stole or the corrupt got away with most of the wealth.

Now, the concept of oil that we have is that it is for all Venezuelans ... that the state resources have been distributed through the social policies that the state has implemented, to the people. 
However, as I will seek to illuminate in this chapter, the actual enactment of redistributive politics through collective consumption and the discourses underpinning it also came accompanied with a host of paradoxes. At the core of the matter were templates and practices intrinsic to the political culture in Venezuela during the Punto Fijo era. This legacy draws on the imaginary of the "Latin American populist-assistentialist state," holding deep roots in political culture across the continent (Auyero 2001; Nuijten 2003). However, these attributes also intersected with cultural imageries of the "demanding rentist citizens," mediated through national symbolisms and idioms. At the same time, the government and the state deployed a quite ambivalent discourse and performance of its rule. On the one hand, the spectacle of the Magical State (Coronil 1997) loomed large in the background, as a state possessing endless wealth and enormous capacities to transform realities. On the other hand, the government at times tried to deploy a quite sobering discourse, warning people against expecting that the state would fix everything and for thinking that oil revenues were endless.

Seen together, the blending of these imaginaries and practices created deep tensions and contradictions within the Bolivarian process. To many popular sector activists and state officials, it was paramount for the future of the Bolivarian process to defeat the historical legacy of individualistic rent-seeking and to foment a new revolutionary consciousness through popular organization and collective consumption. However, the ways in which "oil wealth," "state welfare" and "resource redistribution" were framed through different lenses in different context evidenced once again how ingrained social practices and political culture were rubbing against the ideological goals of the Bolivarian process.

\section{The Paternalist State}

In order to understand these ambivalent imaginaries, we need to capture the historical dynamics and cultural templates that had shaped the relationship between the popular sectors and the Venezuelan state. A friend of mine once told me a popular joke about the adecos (politicians from Acción Democrática). It went something like this: an adeco running for the presidential elections is touring the country to gather votes. In every village he comes to, he promises the villagers everything they want: "We will build you new houses! We will build you a new electricity system! We will give you water! We will build you a new hospital!" Then he goes 
to a village in the interior of the country. He is standing on the podium shouting enthusiastically: "We will give you new tractors! We will build a new road! We will build you a new bridge over the river!" A campesino (peasant) then raises his hand and says: "But señor, we don't have a river here." The adeco then lifts his hand in a sweeping gesture: "But then we will build you a river too!"

This joke starkly brings out the political imaginaries that the Punto Fijo parties engendered: those of seeking to entice followers through lofty promises of lavish spending. It was a pattern of state-society relations with its particular temporalities and political aesthetics, well known for students of Latin America. The "populist tradition" in Latin America has always hinged on "grandiose promises" to the masses that are later fulfilled, or not fulfilled, depending on the social inclination and political honesty of the incoming president. Both Auyero (2001) and Lazar (2008) discuss how "election time" in Argentina and Bolivia constitutes a particular period whereby the citizen tries to "seize upon the moment" and obtain the most benefit out of the "political opportunity window" before it closes again after the elections. Adrian, the government worker that we got to know in Chap. 6, described these dynamics during the Punto Fijo period like this:

For the Venezuelans it was above all about obras (public work) the streets, street lights ... when the electoral processes starts, then they come doing their campaigns, they start to offer, they do and do and do when once they are in power the period of forgetting starts.

So I take care of the population for months, some months, for the electoral campaign, I become president or governor and then come four years of forgetting, that is how the population was educated, saying "let's wait for the new elections and they will fix the street." Do you understand? So the next year they fix the street and then comes four new years of forgetting. That was the dynamic and that is why we are talking about a paternalistic culture.

Rosa, who had lived in the barrio of Casalta 3, high above Propatria, since she was a little girl, recalls that prior to the elections in 1978,

Luis Herrera came to do campaigning in the community. He came here and started talking to my mother, because, you know, the typical photo of politicians with the old lady, the photo drinking coffee with the old lady, and well, in reality we were ignorantes (ignorant people), or not ignorantes, 
but we had other concerns than politics, we had to get food, we had to look for work, we had children that we needed to get into school, these things ... so we were apathetic what politics was concerned, the majority of people in the barrios were concerned with finding food and try to fix their rancho (barrio shack).

Luis Herrera (COPEI) won the elections and assumed office in early 1979. Shortly thereafter, the sewage system and other basic infrastructure were built in the community, Rosa recalled. She thought that this was because he himself came from a more modest background than other presidents in the Puntofijo era. "And well ... in spite of all the corruption in Luis Herrera's government-even though it was Carlos Andrés [Pérez] who took home all the medals in what corruption is concerned-one can say that there was a little bit more done for the barrios," she concluded.

Many people also brought up the common practice whereby local party brokers (Auyero 2001) went from barrio house to barrio house before the elections and distributed bricks or bags of food in exchange for promises to vote for the party. Moreover, people commonly sought out the brokers for petty assistentialism such as bricks and zinc sheets for their ranchos. Acción Democratica's political profile and voter base implied that they cultivated tighter clientelistic relationships with popular sector communities than COPEI. Rosa recalled that her now-deceased father conceptualized the difference between the two parties like this: "the adecos are like hens; they eat and leave their mess so that those around them also can pick up some. But the copeyanos are like vultures, they eat off everyone else whilst no one eats off them."

The administrative architecture of the Venezuelans state as outlined in the 1961 Constitution accentuated assistentialist and clientelistic dynamics between the political parties and informal neighborhoods. As the Constitution did not recognize municipal power as a separate political branch, "the municipal councils became mere extensions of the central government and the dominant political parties" (Rivero Santos 1995:5). Consequently, popular sector struggles for public services such as roads, light posts, sewage system and water "directly addressed issues totally under the control of the centralized and populist state apparatus controlled by the parties" (Rivero Santos 1995:6). Moreover, making use of public services, or obtaining jobs, also frequently required partisanship. 


\section{The Legacy of Assistentialism}

A clearer picture now emerges of the habituated political culture and dynamics fostered during the Punto Fijo era. For decades, the popular sectors were accustomed to using political opportunity windows to "receive" whatever was on offer; otherwise one had to draw on direct mediation between the political parties and its client network. (Here it is worthwhile to recall our discussion about la palanca - the door opener-in Chap. 6.)

In its place, the ideological focus of the Bolivarian process was twofold. One, to provide universal access to public welfare such as health, education and pensions. And two, to establish broad-based popular organizations that could serve as the foci for fomenting collective local development and welfare improvements. In order to achieve the latter, it was crucial to develop critical consciousness among people about their collective rights and duties as citizens, and, as part of this process, to reverse the historical legacy of individualized strategies for rent-seeking. However, many popular sector activists were deeply concerned with how the habituated assistentialist and clientelist political imaginaries hampered popular organization. Adrian, the government worker we got to know in Chap. 6, commented:

I think that organization here is not very easy, because unfortunately they taught us this individualistic culture, the paternalistic culture, that is, that the state has to give, that the state has to give, that we don't have to do anything, that the state will give things to us, and of course, many years will have to pass before this reality is reversed, and this is what is expressed here in this moment, that the population doesn't understand that organization is what is needed.

What Adrian referred to here was on the one hand, the habituated expectation that the state would come and "give," however little, in the critical "hand-out" conjunctures of the electoral cycle. On the other hand, he referred to the difficulties in incorporating "ordinary" people, who were not accustomed to participating in collective struggles, into community organizations. As we have previously discussed, a broad and heterogeneous popular movement had indeed emerged following Chávez's election, drawing on popular organization and critical consciousness that was born through social struggles in the decades prior to Chávez. However, this ideological orientation and prior organizational experience was not equally distributed in the population. 
Many in the older generations were also cynical of new community initiatives and political initiatives emerging from the government, brushing them off with es la misma vaina que los adecos (it is the same thing as the adecos), meaning that they considered it as promises that would not materialize. In a similar manner, many people considered the communal councils to be replicas of the former neighborhood organizations that served as client organizations to Acción Democratica. These former neighborhood organizations had different formal names (see Rivero Santos 1995), but people habitually referred to them as juntas de vecinos. The association between these organizations and the communal councils made people prone to think that either those who were active in the communal councils had joined solely to attend to their individual interests, or that it was communal councils' spokespersons' responsibility to "fix" things for the rest of the community. In any case, these habituated perceptions of neighborhood councils as self-serving client organizations impeded many people from joining the communal councils, constituting a great deal of frustration for grassroots activists trying to mobilize their neighbors.

\section{My Drop of OIL}

For others, the government's pledge to distribute oil revenues magnified people's expectations of receiving "their drop of oil." To paraphrase Nuijten (2003), the Venezuelan state became converted into an expectationgenerating machine, fueled by not only the tangible results of redistribute measures and social spending, but also by the seeming abundance of wealth at the time. Many community activists were highly critical of their fellow neighbors whom they perceived as demanding not only toward the state, but also toward the voceros and other people in the community that were actively participating in various projects. Often, these community activists experienced that they got little gratitude in return, and instead received scolding, accusations and criticism. Many of the internal conflicts of the communal councils were related to the different and contradictory understanding of what these organs were supposed to provide, who was responsible for providing it and how. I once asked Candy, a community activist in 23 de Enero, why she thought that it was so difficult to organize people. They were dealing with the problem of mobilizing enough people to stand for the elections they were organizing. She answered dryly: "I have been everywhere in these streets. There is nothing new you can tell me. I know Venezuelans. They want you to bring them a bag of food, then 
they want you to cook the food for them, and then they want you to stick it into their mouth." She added, "Oh, mami, what they really want is an oil well in their backyard." Somewhat less pungent, a public functionary in the Libertador municipal administration who had worked closely with the communal councils eloquently summed it up this way:

People have different criteria, because there are those who think that Venezuela is a super rich country and that the state has to give them everything, there are those who think that there is a struggle for power over using the oil in an arbitrary manner and keep on handing out and keep on destroying the country, while only a small group is making itself rich, and there are those who think that if we distribute it well we can resolve all these problematics that we have...

\section{Papa Government}

Chávez expressed keen awareness of the cultural and political tradition that the Venezuelan electorate was used to, and frequently spoke of popular mobilization as the prime criteria for social development. He repeatedly reiterated that people could not hope for the state to fix all their problems. As he said in one televised speech: "I am telling you with all my love, but also crudely: Don't get used to coming to papa government for everything 'to give me the little machine that I need'" (Chávez 2005, addressing Núcleo Endógeno Fabricio Ojeda; cited in Aponte Moreno 2008:175, author's translation from Spanish). As we recall from Chap. 7 , community workers in Fundacomunal were instructed by their superiors to emphasize this message, warning people against thinking that "their drop of oil" would come in the form of a gift. Rather, collective organization was a prerequisite for receiving funds. Indeed, except from student scholarships (through Misión Ríbas) and single mother's scholarships (through Misión Madres de Barrio), none of the social programs contained direct cash transfers. In the case of the communal councils, the legal framework for transference of fund was in theory designed to avoid that individual beneficiaries got cash in their hands (though there was many irregularities concerning how this was carried out in practice).

When oil prices started to drop in the spring of 2011 , voceros working with the communal councils were instructed to raise the issue in community meetings. Hedging against future discontent and underlining that oil money was not endless, they tried to inspire discussions about the impli- 
cations the drop in prices would have for future state spending. Thus, at a discursive level, the government was frequently trying to foment a new notion of rent distribution, coupling social welfare with collective organization and a broader ideological horizon of social transformation.

At the same time, the state's lavish spending, which gave the impression of endless wealth, as well as its personalistic style of government, also contributed to reinforcing these notions, striking deep chords of the collective psyche. The habituated practice of soliciting help for solving individual problems was reproduced on a number of arenas. Ever since Chávez was elected, people had the custom of trying to hand him personal notes with requests for help during public meetings. Indeed, when he traveled across the country, he was followed by personnel whose responsibility it was to collect these notes and catalogue them in a special office. Moreover, the vice-presidency—vis-à-vis the presidential palace—had an office dedicated to processing citizens' emergencies and difficulties with other institutions. The task of this office however, rather than providing assistance directly, was to turn to other state entities (i.e., a hospital, a municipal government, a social security entity) and try to find solutions. As a last resort, people came to this office from all over the country. Individual attempts for problem-solving was also on display every day in the top national newspaper, Ultimas Noticias. It has a section whereby people can call or send short messages by SMS. It contained as string of requests directed to the government or President Chávez, or sometimes to a particular institution or just anybody, to, for instance, supply credit for a car so that someone can make a living as a taxi driver, or to provide material for constructing a house, or a lap-top for the children's education.

I want to reiterate that it is not my intention to be patronizing or condescending toward people's efforts to solve their problems as best they can. Rather, the persistence of these practices - reflecting a political imagery as much as historically habituated mechanism of problem-solvingmust intrinsically be understood through a structural perspective. As long as needs are still widespread, and universal access to welfare is hampered by continuous poverty and patchy state policies, these practices necessarily reflect people's attempts to find "a way in" and a last resort when other options are exhausted. Fundamentally, these practices are intimately interwoven into political culture across Latin America, reflecting particular patterns of post-colonial state formation in societies characterized by hierarchical social formations and the monopolization of access to power and economic resources. 


\section{New Values}

Thus, rather than dwelling on these practices per se, my interest here is to shed light on how these tensions between the historical templates of "state handouts" and the ethos of social justice through collective organization and broad social transformation were articulated. A case in point is the social discourses emerging after the launch of the public housing program Gran Misión Vivienda Venezuela (grand Venezuelan housing mission), of which Abigayl and Ramón were beneficiaries. This mission was launched by Chávez in April 2011, spurred by the heavy torrential rains that fell in November 2010, leaving 130,000 homeless and killing 34 people. With the tragic landslide in the state of Vargas, which claimed perhaps as many as 30,000 lives in 1999, fresh in mind, the government pledged that everyone who was left homeless would be relocated to new and safe housing. When the mission was launched, everyone living in inadequate housing conditions was encouraged to apply for a new home. The government vowed to build 2 million new homes between 2011 and 2017, which was the estimated housing deficit across Venezuela. This would be done through a concerted effort of the state, the private sectors and the communal councils, as well as the communes. More than 10 million people registered, supplying data on social and economic conditions, which would be the basis for an analysis on who was in fact eligible. By the end of November 2012, 293,799 homes, apartments or houses, depending on location, had been constructed. The overall goal was set to 3 million homes by the end of 2019.

However, the housing mission generated two different discourses among social activists. On the one hand, it was conceptualized as a question of social justice, and as the state's fulfillment of its constitutional duties to ensure that all citizens had dignified and adequate living standards. On the other hand, it was framed as a state handout to passive, undeserving and demanding citizens that expected the state to resolve their problems. It was public belief that many people resorted to dirty tricks and maneuvers to get an apartment, and that once built, they complained about deficiencies and shortcomings. At the same time, stories were circulating about how the apartment buildings soon became worn-down as a result of the inhabitant's "barrio habits" of throwing litter everywhere, letting the children do whatever they wanted without supervision and a general 
lack of maintenance. As Oscar, the ideological activist from 23 de Enero, said on one occasion:

They give them a fully equipped apartment, and if there is a fork missing they complain. They give them an apartment and six months afterwards everything is in decay, they don't appreciate it. Easy come, easy go. ${ }^{4}$ What is missing here is education, the values.

Adrian, Ramón's brother, shared a similar view. He had just moved into his girlfriend's apartment, in Fuerte Tiuna, which she had also gotten through Misión Vivienda. Adrian's girlfriend had a child from a former relationship and they were expecting a child together within the next couple of months. He was happy about his new living conditions, but complained about the neighbors' behavior-all of whom had been assigned apartments through Misión Vivienda. "There are 8 apartments on each floor, and 6-7 loudspeakers blasting. You don't hear anything. The kids paint graffiti on the wall. The education starts at home, and that is the problem, the lack of education at home. I keep saying: 'Coño, you left the rancho, left the mal vivir (bad living) for a buen vivir (good living). You have to change as well. People have moved to better homes, now you have to change values.'" On one occasion I was visiting one of the shelters that the government had set up for the dignificados - those who had been evacuated from their homes during the 2010 rains. On the wall, there was a poster saying:

"GIVE ME A HOUSE" should be accompanied by "give me a life," "give me a path," "liberate me from the capitalist logic, let's start to be human beings," "let's stop being wrecked merchandise desperately hanging on to the margins of consumer society." Give me a house should mean "LET'S CONSTRUCT A NEW WORLD!"

This discourse about a lack of appreciation of what they had received and the need to change values was tied to a broader moral discourse about how people failed to respond to the call to becoming different kinds of citizens: collectively orientated, socially aware citizens, the New Men and Women we have previously referred to. Eduardo Piñate, a director in the administration of the Libertador Municipality, commented to me that:

What we generally are concerned with is a kind of popular participation that is more based in the political, that goes beyond the revindicative perspective, 
right? Because the revindicative perspective is closely tied to an individualistic thinking, and this is an ideological and cultural issue, right? So, our parish governments, all the assemblies and reunions with the parish government where I assist, and I can tell you that I go to at least ten a week ... they are very permeated by this revindicative thinking, but in order to nuance this, I should also say that we have encountered an emerging growth of collective consciousness, solidarity, that is, every time we go the parish governments are discussing less individual problems and more collective problems.

\section{Mi Negra}

The opposition frequently criticized the government for reckless spending of oil money on the social programs. However, in the electoral campaign for the 2006 presidential elections, the opposition candidate Manual Rosales introduced a new twist to the notion of "my drop of oil" when he introduced a credit card called Mi Negra (my black woman) as his main electoral bait. Rosales promised that if he was elected, the credit card would be distributed to middle- and low-income households, with a monthly sum of 600,000 bolivares (approximately USD 280) for free spending, and with an additional 400,000 bolivares which could only be used to purchase food. The resources to fund this credit card would be drawn directly from the oil revenues, consuming approximately 20 percent of gross national revenues. In 2007, the minimum wage in Venezuela was approximately USD 250 per month. If Mi Negra had actually been implemented, many people would have seen their income doubled over night.

The exact eligibility criteria for receiving the credit card were never clarified. During the electoral campaign, Rosales's people set up tents across the city where people could fill out the forms and obtain their cards, which Rosales promised would be activated once he was installed in the presidential office. The name of the card caused harsh reactions among many (see DunoGottberg 2011). Literally, the term Mi Negra means "my black woman," but the Rosales campaign insisted that it alluded to the black color of oil. However, many people insisted on the inherent racism in the word, as $M i$ Negra is also a folk expression that refers to a "black slave" or "black maid." As previously noted, Polish journalist Ryszard Kapuściński once wrote that:

oil creates the illusion of a completely free life, life without work, life for free ... the concept of oil expresses perfectly the enteral human dream of wealth achieved through lucky accident .... In this sense oil is a fairy tale and like every fairy tale a bit of a lie. (Watts 2004:213) 
The credit card was evidently an attempt to tap into such a vein in the Venezuelan population, sublimating the relationship between the populace and the nation's natural resources into hard cash and a care-free life. I was in Venezuela during the electoral race and the 2006 elections, and my impression was that the popular sector segments didn't really take this electoral promise seriously. In the end, Rosales only received approximately 36 percent of the votes, evidencing that he was not able to tap into the popular sectors that were the main target for the $M i$ Negra campaign. There is a lot to say about why that was the case, but I wish to highlight three things. First, that the popular sector electorate recognized a promise of a "new river" when they saw it (referencing the adeco joke above), and were well aware of the fact that they were being tempted with "election candy." Second, that they had been sufficiently politically formed throughout the last ten years or so to prefer the government's model of collective rent distribution, and that, third, even the humblest shantytown dweller knew that such a measure would have catastrophic economic consequences.

Many community activists at the time commented that Rosales's proposal stood in stark contrast to the political ethos of the Bolivarian revolution revolving around state-sponsored welfare. Indeed, it represented essentially, as one man said, a "capitalist proposal" (Strønen and Waerness 2007) whereby each person could buy what he or she wanted on the market place. However, he said, this was exactly the kind of (neoliberal) social model that had such detrimental effects on Venezuelan society in the past, and from which the Bolivarian process emerged as a counter-proposal espousing collective solutions to collective problems.

\section{The Question of Oil Pathologies}

In 2011, I did an interview with Santiago Arconada, a renowned popular intellectual from the community of Antimano, who has been involved in community organization and popular activism for decades. He drew a linkage between rentenist mentality and consumption, arguing that this was a way of thinking that was imprinted in the collective Venezuelan imaginary, and which would be very uneasily rooted out:

[Consumerism] is one of the largest deformations, distortions of the petroleum rent, I was enraged with my brother when I asked him epa, what's up, what have you been doing, and he would answer "I, nothing, I buy everything ready-made." 
There was a time when this answer became a sort of fashion, people perceived it as ... they said it with the greatest pride ... like being proud of being a person that produces nothing and as by magic receives a resource to buy everything in life ready-done, not to produce, to buy. This way of thinking, like a chip in our hard drive, continues to do us great harm....

I believe that we cannot ... I have heard in the fields of health studies that a tumor that was developed over 20 years cannot be cured in three days, you can start the process of reversing the tumor but it is going to take the same time as it took to develop it ... what I want to say is that we cannot retreat from 100 years of a culture of petroleum rents from one day to the other ... what is also certain is that if we don't start, we will never change ... if the vision of that petroleum pays everything remains, that we will not be able to question the essential elements of our daily lives.

Arconada represents the ambivalence found among many popular ideologues and organic intellectuals: wholeheartedly supporting social and political change away from elite rule and neoliberalism per se, but critically and cautiously observing how the Bolivarian process was unfolding.

As he pointed out, there are certain historical processes leading up to Chávez's time in government that continued to hold great sway over social imaginaries and political life. Throughout the past two chapters, I have tried to tease out some of the frictions arising in the faultlines between Venezuela's historical trajectory as an oil state and the ideological goals of the Bolivarian process. Notions of oil wealth and consumption loom large in these narratives, emphasizing how Venezuela's turbulent and ambivalent relationship to its national patrimony is seen as having engendered both the potential for great personal and collective prosperity, as well as great harm.

Discourses of oil wealth and consumption, in Venezuela and elsewhere, draw on a host of contested notions over how oil wealth should be spent, how and by whom it should be distributed, and who is deserving of receiving a piece of the pie. Each of these questions are wrapped in complex economic, political, cultural and ideological schemes with global reach. However, as anthropological scholars of oil have emphasized, oil is in itself imbued with an imaginary power engendering valued-laden and morally ambivalent notions about "oil citizens" and "oil as a way of life" (Appel et al. 2015:27-28). Within these schemes, the trope "oil pathologies," whether it is used to characterize a country, a particular political regime or individuals benefiting from oil rents is frequently looming implicitly in the background. 
However, as a final comment I want to suggest that there is reason to be cautious when notions of "rentist citizens" and "oil pathologies" are brought up, both in scholarly analysis and as articulated in "folk wisdom." These are seductive templates that may be used and manipulated in ideological and class-biased discourses without making explicit underlying political assumptions or agendas. As the Venezuelan economist and oil analyst Carlos Mendoza Potellá maintains in the case of Venezuela:

The abusive use of the label "rentist" has served the supporters of oil expansion [privatization] in a subordinated association with foreign oil capital in discrediting the Venezuelan struggle for ensuring a just distribution of wealth of national patrimony. (Flama 2011:39, interview)

Chávez's critics repeatedly framed social spending for the poor as populist oil-demagoguery. This position is also reflected in the scholarly literature (e.g., see Corrales and Penfold 2007; Penfold-Becerra 2007; Rodríguez 2007). However, these arguments often serve as barely concealed resistance against the very idea that the Venezuelan state should control and prioritize redistributing oil revenues toward its poor citizens. Concurrently, a narrow and one-sided focus on "rentist citizens" or "assistentialist state policies" have the potential to deaden the broader problematic of historical and accumulated unequal distributions of wealth, and the question of how oil wealth actually can be redistributed. This has to be seen in relation to how accusations of the poor's pathological welfare dependencies have deep roots in history (O'Connor 2001), wielding strong justificative power for not redistributing wealth or providing poverty relief. However, as the author Norman Mailer has formulated it:

To blame the poor for subsisting on welfare has no justice unless we are also willing to judge every rich member of society by how productive he or she is. Taken individual by individual, it is likely that there's more idleness and abuse of government favors among the economically privileged than among the ranks of the disadvantaged. ${ }^{6}$

As we have previously discussed, Venezuela's well-off citizens commonly argue that they have become rich because of hard work, while the poor are poor because of laziness and sloth. However, in Venezuela and other countries with low social mobility, high socio-economic status is more 
often than not a result of hereditary luck. And, we may add, an abundance of personal wealth is not infrequently a result of murky or exploitative business, or simply because of in-built structural and political mechanisms that distributes wealth upward rather than downward. It is therefore the poor, who necessarily are the ones in need of assistance from the state, who are often accused of displaying oil pathologies and state dependency. Thus, feeding into a broader discourse of dependencies, amoralities and cultures of poverty (Lewis 1966), the poor are in effect crucified twice: First for being poor, and, second, for being lifted out of poverty through state redistribution of wealth.

That is not to say that we should not critically examine how oil resources are spent and policies developed, or that we should abstain from critical analysis of how particular redistributive regimes are mediating and mediated by cultural and social relations. However, as I have sought to tease out through these chapters, we need to develop our analysis with a keen understanding of the complex interaction between historical and contemporary socio-cultural processes and political formations. In Chap. 10, we will continue this explorative endeavor into yet another contested terrain, namely corruption. As I will show, corruption constituted yet another template that emerged in the context of moral discourses about how Venezuela had become destroyed from within during the Fourth Republic. At the same time, corruption gained salience in the context of community politics, engendering local struggles as well as making visible the plasticity of what constitutes "corruption" on different social and political arenas.

\section{Notes}

1. These statistics are also derived from income-based measurements (INE n.d.).

2. Some scholars have however questioned the impact of the Chávez government's social policy. For example, Ponce and Gonzáles (2015), from the neoliberal Venezuelan think tank CEDICE, argue that social spending had limited effect on structural poverty and that the poverty reduction that did take place was primarily an effect of the oil boom.

3. Cestatickets are checks that can be used as payment in certain shops and restaurants. It is widely used in Venezuela as part of the salary in addition to the monetary payment.

4. In Spanish: "Lo que nada cuesta, hagamos fiesta" [we make a party of what comes for free]. 
5. As a symbolic and political re-definition of the victims of the 1999 landslide, Chavez started to call those that had become homeless for dignificados (the dignified) instead of damnificados (the victims) (see Fassin and Vasquez 2005). This term continues to be used.

6. Thanks to my CMI colleague Elin Skaar for making me aware of this quotation in just the right moment.

\section{BIBLIOGRAPHY}

Appel, Hannah, Arthur Mason, and Michael Watts. 2015. Subterranean Estates. Life Worlds of Oil and Gas. Ithaca and London: Cornell University Press.

Auyero, Javier. 2001. Poor People's Politics. Peronist Survival Networks and the Legacy of Evita. Durham and London: Duke University Press.

Coronil, Fernando. 1997. The Magical State: Nature, Money, and Modernity in Venezuela. Chicago: University of Chicago Press.

Corrales, Javier, and Michael Penfold. 2007. Social Spending and Democracy. The Case of Hugo Chávez in Venezuela. LASA Forum 38 (1): 20-22.

Correo del Orinoco. 2012. Vicepresidente: Barrio Adentro ha realizado más de 745 millones de consultas médicas. Correo del Orinoco, April 16. http://www. correodelorinoco.gob.ve/nacionales/vicepresidente-barrio-adentro-harealizado-mas-745-millones-consultas-medicas/. Accessed February 20, 2017.

Duno-Gottberg, Luis. 2011. The Colour of Mobs. Racial Politics, Ethnopopulism, and Representation of the Chávez Era. In Venezuela's Bolivarian Democracy. Participation, Politics and Culture under Chávez, ed. D. Smilde and D. Hellinger. Durham and London: Duke University Press.

Fassin, Didier, and Paula Vasquez. 2005. Humanitarian Exception as the Rule: The Political Theology of the 1999 Tragedia in Venezuela. American Ethnologist 32 (3): 389-405.

Flama. Liberación y Petroleo. 2011. Entrevista al Profesor Carlos Mendoza Potellá: Interview by the Editorial Team. Flama. Liberación y Petroleo, AprilJune. Caracas: Fundación Editorial El Perro y la Rana.

Gledhill, John. 2008. "The People's Oil": Nationalism, Globalization, and the Possibility of Another Country in Brazil, Mexico, and Venezuela. FocaalEuropean Journal of Anthropology 52: 57-74.

INE. n.d. Indicadores Sociales-Pobreza. Instituto Nacional de Estadistica. http://www.ine.gov.ve/index.php?option=com_content\&view=category\&id= 104\&Itmid=45\#. Accessed February 20, 2017.

Lazar, Sian. 2008. El Alto, Rebel City. Self and Citizenship in Andean Bolivia. Durham and London: Duke University Press.

Lewis, Oscar. 1966. La Vida: A Puerto Rican Family in the Culture of Poverty. San Juan and New York. New York: Random House.

Moreno, Marco Aponte. 2008. Metaphors in Hugo Chávez Political Discourse: Conceptualizing Nation, Revolution, and Opposition. PhD dissertation, Graduate Faculty in Hispanic and Luso-Brazilian, City University of New York. 
Nuijten, Monique. 2003. Power, Community, and the State. The Political Anthropology of Organization in Mexico. London and Sterling, VA: Pluto Press.

O'Connor, Alice. 2001. Poverty Knowledge: Social Science, Social Policy, and the Poor in Twentieth-Century U.S. History. Princeton, NJ: Princeton University Press.

Penfold-Becerra, Michael. 2007. Clientelism and Social Funds: Evidence from Chávez' Misiones. Latin American Politics and Society 49 (4): 63-84.

Ponce, Maria Gabriela, and Lissette Gonzáles. 2015. Pobreza and gasto social en la Venezuela de a Revolución Bolivariana. Caracas: CEDICE.

Rivero Santos, Angelo. 1995. Neighborhood Organizations in Venezuela: "Los Vecinos" Voice Their Dissent. Yearbook: Conference of Latin American Geographers 21: 1-12.

Rodríguez, Fransisco. 2007. Sharing the Oil Wealth? Appraising the Effects of Venezuela's Social Programs. LASA Forum 38 (1): 22-25.

Salas, Miguel Tinker. 2015. Venezuela. What Everyone Needs to Know. New York: Oxford University Press.

UN-Habitat. 2012. The State of Cities in Latin America and the Caribbean 2012. Towards a New Urban Transition. http://www.citiesalliance.org/sites/citiesalliance.org/files/SOLAC-ProjectOutput.pdf. Accessed February 20, 2017.

Watts, Michael. 2004. Anatomies of Community: Some Thoughts on Geography, Resources and Empire. Transactions of the Institute of British Geographers 29 (2): 195-216.

Weisbrot, Mark, and Luis Sandoval. 2007. The Venezuelan Economy in the Chávez Years. Washington, DC: Center for Economic and Policy Research.

\section{Audiovisuals}

2007. The People and the President. A Portrait of the Bolivarian Revolution. Dir. Iselin Strønen and Hildegunn Wærness. Bergen, Norway: Geriljastil Productions.

Open Access This chapter is distributed under the terms of the Creative Commons Attribution 4.0 International License (http://creativecommons.org/ licenses/by/4.0/), which permits use, duplication, adaptation, distribution and reproduction in any medium or format, as long as you give appropriate credit to the original author(s) and the source, provide a link to the Creative Commons license and indicate if changes were made.

The images or other third party material in this chapter are included in the chapter's Creative Commons license, unless indicated otherwise in a credit line to the material. If material is not included in the chapter's Creative Commons license and your intended use is not permitted by statutory regulation or exceeds the permitted use, you will need to obtain permission directly from the copyright holder.

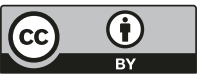




\section{Corruption and the Extractive State}

Corruption is the mother of the crisis, of all the problems, it has extended to all levels like a cancer, to the lowest levels, it has taken on a thousand faces and a thousand ways of camouflaging itself ... to wage a war against a monster with a thousand heads is a complex process, long and difficult ... it is very difficult to get rid of all these anti-values that are immersed in all sector and all institutions. (Hugo Chávez, cited in Díaz, Eleazar R. (2006), author's translation from Spanish)

Caracas, November 2012: I hadn't seen Alfredo for a year and a half, when I went to visit him upon my return to Venezuela. The day before we had agreed to meet via SMS, and since I had visited that particular community many times, I felt safe about going alone to his home, located in the middle of an established barrio community in 23 de Enero.

Alfredo was sitting in the living room waiting when I knocked on the door. It was close to Christmas, and a nacimiento-the cherished Venezuelan Christmas crib featuring Maria and Joseph in the manger with the newborn baby Jesus - was balancing on a shelf in the corner. Alfredo was one of the most dedicated believers in community work that I had met throughout the process. He had been involved in politics all his life, and had been central in organizing both the Health Commitee and the Land Commitee in his community ever since Chávez first came to power. In the past years, he had been vocero de finanza-finance committee spokespersonin the communal council. 
Last time we spoke, he told me of the problems that he was having because a competing faction in the community had embarked on a campaign of outmaneuvering Alfredo and his friends who, for a long time, had been central to community activism.

We started to chat, and I soon noticed that something was wrong. After a while he told me that he had resigned from his position as financial spokesperson. The other faction had smeared him, spreading rumors in the community that he was corrupt and that he hadn't done the rendicion de cuenta (present the balance sheets) to the community, even if that was a lie. They had also claimed that he hadn't done any work in the communal council, which also was a lie, and the evidence was there for everyone to see-the work was visible there in the community, stairways, several new houses built and others reconstructed, and above all a huge project of drainage and reconstruction of a hillside on the outer slope of the community that put the houses on its edge at risk for landside. He got up and found his resignation letter for me to read. It was signed on June 6, 2011, two weeks after I last saw him. The letter stated that he resigned because of the campaign against his good name and honor, and the untruthful accusations against him and his work as the financial spokesperson. The letter was stamped with the communal council's seal.

Every time I had visited Alfredo during the past years, he had showed me the accounting books for the communal councils-everything listed in orderly columns and accompanied by a folder of neatly stacked receipts and invoices documenting the purchases that the communal council had made. In spite of the two housing projects that he had helped develop, his house had not been rehabilitated-the poor and crumbling apartment with humidity stains on the ceiling was certainly a testimony to that. Indeed, when he made a pot of coffee before we sat down to talk again, I realized that he didn't even have a cup in his cupboard that wasn't broken.

In spite of Alfredo's trajectory as a long-term renowned community activist he had become more vulnerable to power plays after the last electoral round, when he was elected for the second time. In the former communal council he had been accompanied by several long-term friends and allies - all of them long-term activists in the community. But in the last elections the other faction had orchestrated to outmaneuver him, rushing the elections with the help of a promotor in Fundacomunal who according to Alfredo was involved in the "complot," and adding new people to the electoral list from an area adjacent to the community — an area that, it was disputed, did not belong to the communal council. They had all voted for the other faction, probably 
stimulated by sweet promises, and as a result, Alfredo's long-term ally lost the election and was replaced by one of the people in the other faction.

After that, they had then made life difficult for him and smeared his name in the community. Eventually he couldn't take it anymore, and resigned. Now, the others had taken over the communal council and carried out projects that he had been in charge of and raising money for, passing it off as their own work. Moreover, they were skimming off money, Alfredo maintained: "And they couldn't have done that without accomplices in the Alcaldia and Fundacomunal. I have seen them here, visiting, and I ask myself what they are doing here ... they are signing checks and papers and vaina (stuff)." And the copying machine and other items that the communal council had acquired for the common use of the community were long gone; quite convenient since the woman who headed the campaign against him, and now had a central position in the communal council, owned a local copying shop where they charged five bolivares per copy. Moreover, they were charging for writing out constancias de residencia (proof of residence) even if this was supposed to be free. "People say that I should take up the fight, but I won't ... Petra and Maria and the others feel intimidated (they were some of his allies in the community), and they have kids in the street."

"But doesn't the community care?” I asked. "They know what work you have done." "Ahh you know what people are like," he responded. "They sit at home and watch cable TV. They don't want to get involved." He got up and found another one of his folders, with photos of the different events and projects they had carried out. One after one, he placed them in front of me, explaining each one of them. Several photos were photocopied onto an A4 sheet, showing him at the meeting for a larger housing project that was implemented in the area. He pointed to some of the other people who appeared in the photos with him: "She got a house, and she got a house, and she got a house over in the Zona Central." Another photo showed several kids sitting in the street outside Alfredo's apartment making paper kites. "We made paper kites with the kids and went over to the football camp to fly them ... the kids still come to me and say Alfredo, Alfredo, when will we make paper kites again!!" "I am really sorry about all this, I know how dedicated you were," I said, and I really meant it. "Well what can you do," he responded and shrugged. "This is a part of the revolution as well ... politics ... but people shouldn't do dirty politics. It harms the revolution.” 
This story of how the dynamics of a communal council were characterized by rumors and allegations of corruption was not unique. Such stories were structured through a discourse which converted corruption into, to slightly twist Durkheim's concept, a social fact which people thought structured social life and people's behavior. Community activism became a key site where broad notions of social solidarity, "fair play" and corruption became activated as people were struggling to navigate different ideological and moral terrains. Perhaps we could even say that community politics sometimes became condensed into a "micro-cosmos" reflecting the challenges of transforming Venezuelan society from within as political imageries of "self-seeking behavior" and "politics of greed" were mirrored in local-level struggles.

Indeed, the talk of corruption (Gupta 1995) was so widespread that I realized that not only was corruption a key tale about the state as such, but also a key tale about society. I constantly heard tales of how employees, both in private and in public positions, hospital workers, shop keepers and bank clerks skimmed off money here and there. Everyone "knew" that the hospitals in particular were out of equipment and medicine because the employees stole and resold them. It was often said that when the Chávez government bought new high-tech medical equipment for the public hospitals, the doctors stole it and brought it to their own private hospitals only to then go to the press and say that the public hospitals were in a state of disarray. I heard innumerable tales of construction projects that were sucked dry along the way in an un-holy alliance between politicians, public functionaries and construction companies. Tales of shady business deals and the 10-15 percent "gratitude payment" for contracts. Tales about the notorious empresas maletin (suitcase businesses) that acquired contracts by "trafficking in influence" and then subcontracted the work, pocketing the difference. Rumors of how public servants, supposedly in relatively modestly paid positions, suddenly acquired expensive houses, new cars, new boobs or new designer clothing. Rumors of high-level politicians that suddenly moved to the far east of the city and dined at expensive restaurants in Altamira, Prado del Este and Las Mercedes. And in the context of community politics, rumors of members of communal councils that all of a sudden refashioned their homes with ceramic tiles and a new floor, or who all of a sudden purchased a new car or went for expensive holidays on the beach. People had a keen eye for what their neighbors did and bought, hence the proverb "no se ve la mano que roba pero sí la que gasta" [you don't see the hand that steals but you see the hand that spends]. If people spent outside 
their "common pattern," it was quickly discovered and talked about. In short, corruption was seen as an intrinsic part of life, as something that happened everywhere (yet I never spoke to anyone that admitted being part of it). It was by many considered almost a natural part of the human existence. Like one man said about corrupt politicians: "It has always been like that and it will always be like this."

While recognizing that corruption was an intrinsic part of contemporary political life, the dominant Bolivarian narrative articulated that corruption was part of the bundle of vices that had been instilled in Venezuelan society since long back. To change this pattern, formed part of the efforts to construct a new society, and, indeed, Che's New Man.

In this chapter, I will go back in history and disentangle how corruption has emerged both as a social practice and as a meaning-saturated narrative in Venezuela. Subsequently, I will inquire into how the template of corruption was conceptualized within the Bolivarian discourse in the context of community politics, representing a key point of contention in attempts to negotiate new public and private moralities. Through these combined efforts, I aim to offer a "thick" corrective to the often simplified stereotypes of corrupt "Third World" countries, at the same time as the analysis may shed light on why, on a general level, "corrupt practices" are so uneasily reversed.

\section{Anthropologies of Corruption}

Initially, I had little interest in the issue of "corruption." However, I gradually realized that I could not leave it out of my analysis. Rather, as for most anthropologists, it imposed itself "because it matters to our informants and because of the prevalence of 'corruption' talk in the areas where we conduct fieldwork" (Haller and Shore 2005:6). In recent years, there has been a growing body of anthropology literature critically examining scholarly as well as popular usage of the concept of corruption. As a means to counter the notion that corruption is only something that is taking place among Third World "others," significant attention has been paid to corruption in Western domains, including the Enron scandal (MacLennan 2005) the EU commission (Shore 2005) and Italy (Pardo 2004).

Haller and Shore have suggested that "corruption merits more anthropological attention simply because of its inexplicable pervasiveness and the curious fascination that people, in almost every part of the world, seem to 
have with stories of corruption" (Haller and Shore 2005:8). However, the fact that anthropology hasn't included the concept of "corruption" in its disciplinary vocabulary until recently doesn't mean that anthropologists haven't previously observed "it" in our field. But rather than labeling it "corruption," we have resorted to concepts from our historical disciplinary tool box-gift-giving and gift-exchange, networks and kinships, solidarity, reciprocity, relationships of power and moral economies - in an attempt to capture how these forms of exchanges are interwoven in social, political and economic life. More recently, anthropologists have sought to show how corruption is also the legitimate child of the colonial administration. The imposition of a colonial apparatus fostered parallel moral economies intertwining "imposed" Western concepts of rational bureaucracy with localized notions of kinship, exchange, reciprocity and solidarity (Pierce 2006). Corruption may then be viewed as a hybrid child of different sets of economic logics, social moralities and relationships of power.

These perspectives, grounded in "solid" anthropology, continue to inform much of the thinking around the topic. Thus, anthropological accounts of corruption tend to highlight its historical and cultural context (Prato 2004:80, cited in Pardo 2004) as well as how it is interwoven with a broader realm of local social and political practices. Significantly, anthropological approaches to corruption tend to problematize the private-public divide that orthodox notions of corruption take for granted (and hinge on) by showing how these distinctions are inherently difficult to draw, even in "Western societies" (Haller and Shore 2005:5). As Pardo notes,

corruption and its causes must be understood in the context of the inherently difficult relationship between politics, bureaucracy, law and civil society which, in distinctively different ways, mark both Western and non-Western states. (Pardo 2004:10)

The fact that exchanges between differently situated actors have always existed in all societies without necessarily being labeled "corruption," indicates that "corruption" can also be understood as part of the global discourse of modernity interlinked with the diffusion of Western notions of state formation and state-society relations. At the same time, societies still have significant divergent conceptions of what constitutes corruption, illustrating the inherent problematic of adhering to a universal definition of what corruption is. Blat (gift-giving) in the post-Soviet countries and guanxi (networking) in China (Haller and Shore 2005:17) are examples 
of culture-specific social practices that would be termed "corruption" elsewhere.

In one of the, by now classic, anthropological contributions on corruption, Gupta explores how corruption is talked about in the village of Alipur in India. The topic was central to everyday conversations among the villagers, revolving around everything from "the going price" of a service or a loan, to who in the bureaucracy was most likely to lend a "helping hand." In his analysis, Gupta focuses on how the state comes to be imagined through these everyday conversations: "The discourse of corruption turns out to be a key arena through which the state, citizens and other organizations and aggregations come to be imagined" (Gupta 1995:212). This is an approach that has been widely recognized and applied in subsequent studies (Lazar 2008).

However, "corruption" can be widely protested and contested even in societies where it is seen as "normal." "The talk of corruption" often constitutes a profound critique of social hierarchies and power. Our task is to capture what this critique can tell us about how people interpret and conceptualize their society, both in its actual institutional and political form as well as in the domain of norms and values. That is not to say that corruption should be romanticized in the name of cultural relativism. Corruption has a range of negative effects upon society, like "inflated contracts, distorted development priorities, increased exploitation and inequality and heightened uncertainty" (Haller and Shore 2005:7), in addition to undermining democracy and the rule of law (Haller and Shore 2005:7). Moreover, it is the poor who are most affected by these distortions. As Pardo notes:

Corrupt relations draw on an interaction between power (and its asymmetries) and its expedient (dishonest, self-serving, and so on) or incompetent exercise, whereby the misuse of power breeds power and feeds on it. (Pardo 2004:12)

These hierarchical relationships, where corrupt transactions are often taking place, put the poor in a vulnerable position as they seek to have their needs and interests covered. At the same time, it has been argued that mechanisms of corruption serve to fill a gap and provide an opening for the under-privileged in the face of discordant state formations. As claims to the state cannot be made on the basis of universally ascribed rights, the poor can enter by paying - to a certain extent leveling the field slightly. 
Pragmatically speaking, that may be true, but it does not come without a cost. Not only does the "practice of paying" effectively reproduce itself, creating a systematic disadvantage for those who simply cannot pay and creating a constant scramble for resources for those who can barely pay, but it also continues to privilege those in power, thus perpetuating unequal relations of power. As Pardo notes:

Corruption at once draws and thrives on injustice, exploitation of inequality, distortions of power and betrayal of fundamental principles of citizenship, for those that do not have access to, or refuse to engage in corruption are at a disadvantage. (Pardo 2004:11)

Moreover, as Zinn (2005) notes with reference to Schneider: "Those who are in a subaltern class position more often bear the stigma of label associated to corruption; whereas business and political elites can make use of connection capital" (Zinn 2005:239). Corruption may be a "weapon of the weak" (Scott 1985) in a given situation, but the greatest benefits are always reaped by those in power.

\section{A History of Stabilized Corruption}

In Bolivarian political discourse, corruption was one of the key concepts through which the differences between the past governments of the Fourth Republic and the Chávez government were mediated and contrasted. Indeed, one of Chávez's main "war cries" against the old system - which contributed to his electoral success in 1998-was that the governments of the Fourth Republic were both morally and economically corrupt. The tale of the corruption of the Fourth Republic within the Bolivarian sphere was tied to a broader discourse of social decay, political illegitimacy and treason against el pueblo. The descarado (shameless) manner in which corruption was carried out was taken as evidence that society was morally and politically bankrupt. Carlos Andrés Pérez's fame for corruption served as a moral and legitimizing justification for the attempted coup against him in 1992, underwriting the notion that Venezuela had to be redeemed from within.

In order to understand the depth of this narrative, it is necessary to go back in Venezuelan history and tease out the role of corruption in forming both political practices and political imaginaries. Private wealth accumulation through coercion and opportunity run as a thin red line through 
Venezuelan history, ever since the first colonizers established themselves on Venezuelan soil. As the renowned Venezuelan historian Luis Britto García (2013) writes:

Corruption in Venezuela has historical roots. Perhaps a mode of production is nothing else than a mode of stabilized corruption. The conquest was a colossal looting operation, appropriating goods and common work by force to the benefit of a vile minority. In the colonial caste society positions were [bought and] sold, and their discriminatory stratification was prolonged throughout the Republic, leaving as the principal means of social climbing that of quick riches. The Oligarchic Republic and other systems maintained this unequal distribution of wealth stemming from racketeering. With the irruption of the oil and mineral economy, the assets and public incomes exceed that of the private economy, and a collection of new rich and new corrupts [emerges from] trafficking in concessions and from milking the State. (Britto García 2013, author's translation from Spanish)

As Britto Garcia eloquently teases out, illegitimate enrichment by force constituted the very foundations for the establishment of Venezuelan political and economic structures through the colonial era. In the aftermath of the Wars of Independence, political and economic positions continued to be traded through the prerogative of force and cunningness. When the oil economy gained pace in the first quarter of the twentieth century, entrenched social inequalities dominated by political casts and networks became irrigated and solidified by the new possibilities for rentseeking that they engendered. The collusion, meddling and horse-trading taking place between an emerging cast of oil professionals, the government and foreign private oil companies created a shady world of business deals and private and sectorial rent capturing.

\section{The Dark Side of THE BoOM}

I have previously discussed the extravagance and opulence that characterized the first government of Carlos Andrés Pérez during the oil boom in the 1970s. The epoch also created a nexus between immorality and corruption: a public imagery that was projected and diffused from the heights of power.

To a certain extent, state spending had been kept in check during the 1960s because of the limited amount of wealth in state coffers (Coronil 1997:5). However, as the government of Carlos Andrés Pérez embarked 
on a massive spending spree, corruption, at a systematic and endemic scale, became the new norm for political casts. Oil rents washed through the system, grandiose development projects and state policies were put in motion without any checks and balances, and Pérez himself created networks of close friends and allies through strategic trading of political and economic assets.

Several political scandals were exposed to the public, revealing dark connections between political and financial elites, corruption and criminal activities. The boundaries between legal economic activities and corrupt or criminal activities became blurred, and the protagonists of this economy reappeared with a new public face, flaunting their quasi-legal or illegal riches in the public without shame or remorse.

During the oil boom, criminality established its claim as a normal form of sociality. Its ideals were brought out into the open. Its heroes left the clandestine world and proudly paraded in public places, making deals in restaurants, broadcasting their accomplishments in private clubs, flaunting their loots everywhere, seeking the company of society's notables. (Coronil 1997:360)

The emergence of the imagery of the new, ruthless actor in the economic realm also shifted the normative definition of behavior in other spheres:

The notion of the responsible citizen paled before that of the independent individual, a person free from social constraints. To be someone, one had to be clever, daring, and rich; and to be rich, one had to have the power to stand outside the law and above social constraints. (Coronil 1997:360)

Venezuelans had always had an ambivalent relationship with oil, but now oil came to be seen "as the dark inside of nature and as the vicious lubricant of all transactions in Venezuelan society" (Coronil 1997:353). Petroleum came to be primarily seen as money, imbued with an innate "corrupting force"-what Simmel once called "the complete heartlessness of money" (Coronil 1997:353).

The processes of liberalization and privatization in the 1980s and 1990s made ample room for shady and criminal businesses, making well-placed individuals in politics and business perversely rich. It has been estimated that by 1990, wealthy Venezuelans had stashed away the equivalent, or more, of the nation's external debt in dollars overseas (Derham 2010:8). 
This culture of private rent-seeking by illegitimate means circumscribed not only the upper echelons of political and economic circles, but also state bureaucracy itself. Indeed, within the bureaucratic culture you were allegedly considered "stupid" if you didn't use the opportunities to enrich yourself. Tellingly, Gonzalo Barrios, a leading politician, and twotime minister for Acción Democrática, once famously remarked that "in Venezuela, there are no reasons for not stealing." A number of proverbs surged from this "public secret." One of the most famous proverbs, still frequently cited today, is: "No me des, ponme donde hay" [don't give me, just put me where there is]. This meant that one wants a position from where one can amass and accumulate private wealth. Another one is: "Cuanto hay pa'eso?" [How much is there for this?], in the sense that a public functionary might, for example, blatantly ask how much you offer for a "service." A third example is "con los adecos se vive mejor, porque roban y dejan robar," [with the adecos one is better off, they steal and let others steal as well]. Indeed, in 1984, the Venezuelan historian and journalist Carlos Capriles Ayalaco co-authored a book series in three volumes entitled Diccionario de la Corrupción en Venezuela (the Dictionary of Corruption in Venezuela) listing known cases of corruption.

\section{The Class Dimension of the Rule of LaW}

An important characteristic of Latin American societies is that the rule of law is differently dispatched according to class. Commonly, the elites perceive themselves as "above the law," as epitomized by the classic phrase "do you know who you are talking to" (Gledhill 2004:167). This feature can be traced back to the ways in which institutions and principles from the Old World were incorporated into the existing and evolving sociopolitical body during colonial times. As Wiarda notes:

In the New World, classes and castes were strictly segregated; justice was similarly dispensed on a sectorial and not an egalitarian basis. When men talked of "rights" they were not referring to any abstract Lockean "natural" or individual rights but rather seeking to guarantee and frequently enhance the "fueros" or special privileges that were inherently theirs because of their or their group's place and status in the society. (Wiarda 1971:440)

Thus, "the rule of law," as well as the enactment of rights and duties, was not universally applied, but rather "strategically" used according to 
accumulated power and privileges. As Gledhill notes with reference to DaMatta, the implementation of liberal constitutions in the continent, with its emphasis on equality before the law, actually served to perpetuate inequalities. The powerful were above the law anyway, as they could draw on their social connections and status. The poor on the other hand were those who would feel the force of the law if they transgressed it (Gledhill 2004:166).

This historical conceptualization of the rule of law in the public domain is helpful for illuminating Bolivarian narratives about elite relationships, the political system and corruption in the Fourth Republic. Intrinsically, these are tied to a broader notion of inequality and injustice, whereby the rich historically got away with "anything." As Gonzalo Barrios, the leading Acción Democratíca politician and two-time minister quoted above once said: "What is stolen remains stolen, as long as it is sufficient to pay off judges and lawyers" (Díaz, Eleazar R. 2006, author's translation from Spanish). In other words, corruption has historically been considered a "class privilege," both by those who took advantage of this privilege, and those who witnessed it from the outside.

\section{Venezuelan Personhood and the Origins of Viveza}

What is going on here is a slow, dramatic and desperate effort of a society to assume itself, in a territory and within habits and codes that don't correspond to them, nor expresses them, and occasionally, don't even make sense to them. (Cabrujas 1996 [1995], author's translation from Spanish)

It was José Ignacio Cabrujas, one of Venezuela's greatest playwrights, writer, actor and public intellectual, who uttered these words. Working between reality and fiction his whole life, Cabrujas tried to penetrate the innermost soul of Venezuela. Without mercy he pointed to the weak spots of the nation, exposing vanity, self-delusion and self-deceit in a forgiving yet unsparing manner that only an insider can get away with.

The quotation is from one of his latest speeches, 11 months before he died in October 1995. At an event entitled La Cultura de Trabajo (the culture of labor) in the theater Ateneo de Caracas, Cabrujas gave a merciless verdict on what he considered to be Venezuelan culture, work ethic and national essence. His conclusion was quite gloomy, as the quotation illustrates. He maintained that Venezuela lacked an autochthonous culture and a vision for the future. The historical process of colonialism, of trying 
to adapt to, and mimic, all things foreign had deprived Venezuela of an inner self, of an integrated core, he argued.

Venezuela hasn't been inaugurated, and her capital Caracas neither. It is a city without a vision, without memories, with nothing particular to her, it is a temporary project. The whole of Venezuela is a temporary project and besides it has the culture of a temporary project. ${ }^{2}$ Here we have always been confronted with the dilemma that what we are, what occurs to us, our behavior, our historical self doesn't correspond with our books, with our verbs, with our words, with our institutions, with our laws and codes. There is an enormous difference between reality and the fixation of a cultural framework in the country. The laws that we have are not ours, it is a lie that the Criminal Code castigates crime, commerce in Venezuela has nothing to do with the Code of Commerce, it is a lie, above all that the constitution expresses the project of a nation, her innermost desires. (Cabrujas 1996 [1995], author's translation from Spanish)

Cabrujas maintains that what prevailed is the victory of opportunism, of the celebration of la viveza, a word derived from the term vida (life) "and we managed to confuse it with viveza, we think that being alive is to do mischief, to say that a person is viva, vivo (alive) because they are plotting something, they are up to something."

In his speech, Cabrujas held high the image of Bolívar, the visionary, the sublime man, true to his dreams and aspirations, uncompromising and morally uncompromised. For Venezuelans, Bolívar has become a paradigm, an enigma, their only bond to the sublime and the elevated. But paradoxically, Bolívar wasn't really a Venezuelan, Cabrujas said. The real Venezuelan is the villain in the story: General José Antonio Paez, who betrayed Bolívar and betrayed Gran Colombia. Paez: "the cunning, the astute, the mediocre, he who was incapable of pondering a dream." Cabrujas quoted a letter that was sent to Paez from the country's merchants at the time, saying that "[This] is a Venezuelan letter, completely." It read like this: "Esteemed General Paez, it seems to us that the project of General Bolívar is incompatible. We have struggled selflessly for overcoming the Spanish colony, the Spanish power, we have been killed in the battle fields in order not to have to pay taxes to the Spaniards, and what, are we now going to pay taxes to the Colombians? No." Then writes Cabrujas:

This is the reason why a sublime dream collapsed, because all the merchants of Venezuela decided that paying taxes to the government of Santa Fe de Bogota was a crime and something anti-Venezuelan. 
And he continues:

This is the point where the sublime stays behind and the cunningness starts, the astuteness, against the Bolívar of the past, the complex dream, distilled, difficult, from the enterprise of enormous magnitude, emerges the trap, the sideways, the by way of, the meandering, the manner of coming, of not losing ... this is a big part of our history.

Cabrujas's speech has more historical un-packing and sophisticated nuances than I can cover here. It is also so culturally rich and subtle that numerous interpretations can be drawn from it. However, I wanted to quote him here because he manages to indicate the deep-seated and complex template of viveza, or what is called la viveza criolla in several Latin American countries, or in the case of Brazil, jeitinho.

The concept denotes a form of cunningness and calculated astuteness that forms part of the Latin American imagery of collective personhoods and social arrangements. "First we invent the trampa (the trick, trap) and then the law, with enough cracks to allow us to go through with la trampa," said Ezequiel Martínez Estrada, Argentinian intellectual and author (La Nueva 2010, author's translation from Spanish). It describes the socialization of an individualized and shameless anything-goes behavior, whereby only a fool obeys the rules.

In Venezuela, the concept encapsulates everything from corruption to shady or semi-legal rebusques (inventive ways of making quick money or earn an extra income), jumping ahead in the bus line, pushing one's way through by force in a traffic jam, refusing to offer prioritized seating to elderly and pregnant people on the metro, a general lack of respect for others and any kind of self-seeking behavior. It could also be used to denounce politicians or career climbers, or anyone who seek to get ahead through cunningness and foul play.

In colloquial speech it is often used when someone tries to be clever or trick themselves out of (or into) something, as in no seas vivo/a (don't be inventive/don't be mischievous). While it is commonly referred to as a negative trait, it is also at times ambiguously interpreted as a positive trait symbolizing the ability to survive in a difficult environment, a "talent for life," and, to a certain extent, social success. Sometimes, you would hear people practically boast about their capacity to enrich themselves through petty corruption or favorable rebusques. Among some, it seemed to be considered a sign of masculinity. 
Thus, viveza represents a dense social signifier, which ambivalently and depending on context describes both a negative trait and an ability to get ahead, to not be left dumfounded and outmaneuvered by others who are more agile. Because of this ambivalence, it also reduced the effect of shame as a social control mechanism, as well as undermining social trust. Correspondingly, viveza is considered to fuel and amplify corruption and dishonest practices because it creates an attitude of "if I do not do it, someone else will do it," or, "why cannot I do it if everyone else does it."

I want to emphasize that these social templates and practices imbued in the concept of "viveza," should not be read as a "proof" of individual or collective pathologies. Such discussions always actualize the question of politics of representations, not least in the context of poverty and inequality (Bourgois 2003:11-18). However, what I want to illuminate with this section is how the concept of viveza forms part of a broader social narrative about norms and values steering political and social life, crafting both individual and collective identities. In Bolivarian discourse, it emerged as part of a discourse advocating for the refoundation of society through fostering new individual moralities-epitomized by the imagery of Che's New Man-through collective organization and critical consciousness. Together with other templates, such as individualism, consumption, greed and lack of values, viveza was part of a story of not only economic corruption, but also social corruption in the sense lack of solidarity, decency, honesty and fair play. As I have sought to show throughout the past chapters, these narratives about today's moral decomposition were framed as the outcome of the Punto Fijo regimes' blatant amorality, and capitalism'sand later neoliberalism's - erosion of the social fabric and public morals.

\section{Reversing and Contesting the Moral Crisis}

Coronil argues that corruption forms part of a broader array of social disorders emerging from the thwarted form of capitalist development taking place in the Latin American continent:

"Corruption," a word that condenses multiple meanings related to the selfseeking violation of public norms-from idleness on the job to clientelism and nepotism, from petty theft to blackmail and murder-has become an endemic structural phenomenon widely accepted as an inevitable part of everyday normality. (Coronil 2011:39) 
However, even though it has become part of everyday life people haven't stopped hoping for something else:

But this economic and moral crisis far from extinguishing it, has rekindled the hope that someone, or something, will offer a solution to our social fragmentation and establish a sense of collective well-being. The turn to the Left has been an expression of this hope. (Coronil 2011:39)

In Venezuela, the Bolivarian revolution was cast as that "someone, or something" that could transform Venezuelan society into a kinder, more orderly state of being. People put their hopes not only on the fact that the Bolivarian state could promote a new mode of state culture, but also on the fact that the process intrinsically would change people "from within"- their hearts and minds-so that a new social order could take shape. As a social activist writes on the activist forum www.apporea.org:

It cannot be denied that our revolutionary process is full of acts of corruption ... but they are fruit of the immaturity of the revolutions, that is, in our ranks there is a diversity of human beings: those who are supporting the process but don't trust it. Those who are participating in order to satisfy their economic interests. Those who have political interests .... There are those who dress in red but who are white and green on the inside. And there are those who put their mind, heart and life into the revolutionary process. (Díaz 2009, author's translation from Spanish)

The dominant political narrative about how this "social disease" has gained foothold focuses on Venezuelan state formation since colonial times and on the fraudulent rule of the Fourth Republic. It is useful to consider Oscar's words, which illustrate the direct linkages drawn between historical trajectories and the contemporary challenges within the Bolivarian process:

OSCAR: What is happening is that ... since our process of independence, those struggles were accompanied by dealing out land, by control over houses ... all the wars that were taking place during the independence period in the 1880 and up till today ... the important military figures among the ruling casts, who had the weapons, start to get engaged in these economic relations as well, in trading with the European countries, a form 
of slavery, because this doesn't come in the genes, I mean, they have told us that we are corrupt, because this is normal and common. But no, this comes from a concept of class, that there are some people who need to have more and more in order to be well, and for that they have to screw up others. And you see, this government hasn't gotten rid of this. It is like the adecos used to say: "Ponme donde hay."

ISELIN: Ponme donde hay?

OSCAR: Yes, that was the adecos.

ISELIN: What does that mean?

OSCAR: It means like "where are the resources" or "where is the money," it was like a saying among the adecos, "find me a place where there is, don't pay me," because if I am in a position to manage a budget in a municipality or a budget for whatever, I use this position to charge my 10 percent, my 15 percent, or through some scam I build up some grand business and tentacles. And in effect, things haven't changed. Look, all the director or sub directors of whichever ministry, whichever state institution, has chauffeurs, has a paid mobile phone, has a great car, has a salary, and through this he has the dispositions, or like, the resources that give him power, that give him decision-making power, and many people affiliate with him in order to, well, to get a small contract, and this is corrupting our communities, our communities don't escape this. Today, in the communal councils, there are fights and disputes because people owe money or because people make some business and don't pass on all the money to the community that they really received.

In Oscar's formulation, one recognizes the often repeated narrative of how the historical heritage of corrupted state practices and "privileges" attached to public office had also permeated the Bolivarian process, while at the same time bringing the communities into the realms of corruption. In the past, poor communities were generally not accustomed to wealth. To the extent that "contentious" money did trickle down, it was through spoils in the form of clientelist networks, populist-style handouts and small-scale corruption. However, this "scrambling for spoils" was seen as having been installed into people, and now that more wealth was 
available, rent-seeking practices became reinforced. As Miche, one of the promotores in Fundacomunal worded it:

MICHE: The weaknesses, well, we all know what they are, here in Venezuela there aren't other people than the very Venezuelans, who have been here for 40,50 years, and, at the end of the day, we are dragging along with us the same vices that have existed for 40, 50 years here ... it's not like people from Mars have arrived to organize us. Why am I saying this? Because the same people who are now in the communal councils are the same people who were with the adecos, with the copeyanos, with Movimiento al Socialismo (MAS), which I am saying with quotation marks...

ISELIN: The people in...?

MICHE: The people in the communal councils. Because the majority of the people involved are older people, 40, 50 years, or that is like the average, there is a low degree of participation among the youth, and that is why they are dragging along with them the same vices from 40 years ago, and as there are now resources available el gusanito de la corrupción (the worm of corruption) is eating them and they are always looking for ways to skim off funds or get into corruption, well, here I mean corruption not only in the manner of stealing money but also in the sense of helping someone you know more than someone you don't know, all this kind of human misery...

In the section above we discussed how the template of viveza encapsulates a particular form of social cunningness also engendering corrupt practices. People often attributed to other people a remarkable capacity of inventing trampas (tricks) to win a struggle or to get their hands on money, a feature of community politics that frequently generated tensions within the communities. These conflicts often played out between competing fractions with different "interests" and often different ideological reasons for partaking. The following case study about a long-term conflict in a communal council serves to illustrate how these processes played out in practice. It shows how the collusion between corrupted state officials and local struggles for power translated into a prolonged process whereby the community was negotiating what kind of moralities should guide community organization. 


\section{Negotiating Moralities}

This communal council had been involved in a conflict over power and resources dating back to a housing project developed by the foregoing members of the council that had now been replaced with new members after elections took place in 2011 . The initial project had been developed through a meticulous process conducted by the committee for housing and infrastructure, who had been mapping out the needs and deficiencies of all the houses on the street. Based on that investigation, a prioritized list was elaborated and handed to the Fundacomunal, which eventually approved the project. However, at that point, something happened. From what I gathered based on my long-time interaction with this particular communal council, a member of the community who worked in Fundacomunal "conspired" with the heads of the finance committee who had the authority to release the funds from the banking account, and changed the list of beneficiaries. That move was discovered by another member of the community who also worked in Fundacomunal, who in turn contacted a person she knew in Safonaac, the institution directly in charge of depositing project funds into the accounts of the communal councils, once the projects were approved by Fundacomunal. However, by the time that account was frozen, some members of the community, allied with those in the finance committee, had already withdrawn their checks.

The project was then stalled, and the communal council that had been responsible for the project ended its term. Thus, it was up to the subsequent communal council, which was elected at great pains as people in the community had become cynical as to what the matter was really about, to get the project up and going again. The finance committee of the former communal council "disappeared," refusing to meet up and present its financial statements to the community. Eventually, after a lot of back and forth with Fundacomunal over whether the bank account could be opened again, the new communal council was promised that it could go on with the project if a community consensus was reached over who would benefit from the initiative and if the money was spent according to plans. This brought tension to the community as the communal council was, after the new elections, divided between two factions that had control over the project and over the key positions in charge of overseeing accounts and releasing funds. After a series of heated community meetings, the last part of the discussions took place behind closed doors, in a meeting attended by voceros of the communal councils (where I was also 
allowed to be present) during which members reached an agreement on those that would benefit from the project. These allocations were first and foremost based on the census of documented needs, though it seemed as if some horse-trading was also taking place over who, among the friends and allies of those present, was needy enough or deserving of being included on the list. At the subsequent community assembly meeting, when the list and the planned proceedings for releasing funds were announced, for the most part, people embraced this community "truce." At the meeting it was made clear that it would no longer be allowed to hand out personal checks to house owners, as had happened before. Now, the house owners had to elaborate a budget with a hardware store, and a check would be written out to the store so as to eliminate the possibility of people directly accessing the funds. In the meeting however, some people, and one woman in particular, were disputing this new practice, arguing that it was nobody's business if they actually repaired their kitchen or their living room with the money they received. The woman thus proposed that the checks be written out to individuals instead of to the hardware store. The argument was obviously not completely coherent-she could have gone to the hardware store and worked out the budget herself. But as Teresa, one of my contacts in the communal council commented afterward: "She just wanted to have her hands on the check; that is what she wanted." Thus, what took place was a subtle negotiation over the manner in which the legal procedures of the communal council were to be carried out-a subtext that everyone, including this researcher, understood.

\section{The Corrupt State}

In the context of community politics, I often heard rumors or tales of how public functionaries "lured" people into corruption through enticing them into "deals" or promising some form of "help," thereby making people in the communities accomplices in scams that were, above all, an expression of ingrained dishonest practices of the state body. Miriam, for example, was utterly enraged by some of her co-workers who allegedly engineered such scams, considering it deeply immoral and threatening to the Bolivarian process:

I don't mingle with crooks; if you stole a check from a communal council you have to assume your shit, because you cannot steal money from the communal council, you cannot steal from el pueblo, steal from the rich but 
not from el pueblo. And you stole money from someone poor, and that is against the principles of the revolution and also against the principles of God, you see? You can have all the problems in the world, but you cannot take something that isn't yours, you cannot take as much as a bolivar from a communal council you see? That is like stealing candy from a child.

As we learned in Chap. 7, Miriam was deeply concerned with how the institutions were directed by people who seemed to be more concerned with their own interests rather than with attending to the communal councils and nursing popular power by displaying a revolutionary moral. For her, petty corruption by public officers was evidence of how the vices of the Fourth Republic continued to hold sway over public institutions. However, she also perceived people in the communities as vivos, as the following quote, formulated in her usual straightforward manner, indicates:

What happened before was that the communal councils were formed because ... people were going to take the money, they didn't participate with the intention that our Comandante wanted, to organize themselves, to help the communities, they just meddled their way in so they could take the candy or the money that the president was giving for the communities.

It should be noted that what Miriam said here is in no way descriptive of all communal councils, something she also emphasizes later in the interview. However, this dynamic was believed to be widespread in the first years of the communal councils. Many community members went to public institutions to denounce their fellow neighbors who had stolen common money, but to no avail as the judicial status of the communal council members and their public prosecution were not contemplated in the law. This was deeply concerning for lawmakers, ${ }^{3}$ which is why the 2009 reform of the law for the communal councils provided for the prosecution of communal council members who embezzled funds. The law also dictated that family members, up to fourth-degree consanguinity, could not occupy main seats in the communal councils at the same time, preventing them from becoming a "society of accomplices."

The initial penetration of corruption in the communal councils was facilitated by the fact that this model of community organization was not yet known or understood by all members of the community. This gave ample leeway for some "inventive" individuals to steer the process as it pleased them. As public outcry over neighbors who were stealing "the 
community's money" grew, and people became more and more aware of what the communal councils consisted of (and the social gains they could bring), the community's "panopticon" was increasingly activated. People seemed to believe that major cases of corruption within the communal councils decreased after the first few years of their functioning, though rumors of "cuts" here and there were always widespread. But as Lazar (2008) also notes for community organizations in Bolivia, "minor compensations" are often socially accepted as long as they are not too much. Members of the community recognized that voceros couldn't work for free, but the ambiguities of what constituted corruption or not, and the ethos of voluntary work inscribed in the formal design of the communal councils, made it a contentious topic as to where the compensation should be drawn from and how much.

For example, once I visited a communal council that was in the process of constructing and rehabilitating several houses in its community. I had traveled with Gerardo, a promotor integral from Fundacomunal, up to the highest hills of La Silsa, next to 23 de Enero. We spent the morning visiting the different houses and talking with the workers and the house owners before we went to the home of the leader of the communal bank in order to fill out the necessary paperwork that Gerardo needed for bureaucratic purposes in Fundacomunal. On the metro ride back home, Gerardo confided that when the housing project was first launched, the ladies in the communal bank had tried to do some "creative accounting" and that he went down hard on them. He had told the leader of the communal bank that she could not play around with the invoices, "because you are the one that will pay for it" (if it gets detected) but that everyone recognized that she worked for free, and that, for that reason, she should rather cut a deal with the workers to get a share. I asked if that was common and he answered that, yes, it was, "but I wouldn't know how." This episode illustrates how gray areas of the law and folk perception of fairness to some extent interfered with how corruption was socially evaluated in the communal councils.

\section{Ambivalent Moralities}

As Gledhill notes with regards to higher-level corruption, "popular protest may reflect only antagonism to exclusion and excess, rather than objections of principle" (Gledhill 1994:104). Similarly, everyday lowerlevel corruption may be thought of as a blurred boundary between what is "fair" and "justified," and what is "crooked" or "greedy." In everyday life, 
Venezuelans are confronted with a range of daily chores which forces them to deploy, or not, strategies that go against normative or legal boundaries. People may choose to pay a public functionary for "a little help" instead of seeing their papers placed at the bottom of the paper stack because they know no one "on the inside." Or for example, it is compulsory to have a medical certificate in order to receive a driver's license. But instead of going through the toilsome process of waiting at a doctor's office for an appointment and pay for the routine check, one can easily buy a medical certificate from a "sympathetic" doctor. (When I accompanied a friend to get her driver's license, the office of the "sympathetic doctor" was conveniently located right next to the office that issued the driver's license.) It is also compulsory to take driving lessons in order to get a driver's license, but one just needs to ask around in order to find someone who can issue a license without requiring proof of driving lessons-of course, in exchange for a small sum of money.

To a certain extent, corruption holds a spot on the opaque scale of moral ambiguities that is between how things are and how they should be. Upon closer scrutiny, what people consider as corruption is not clear-cut, and what is also not clear is if all forms of corruption that contravene the law are considered morally "bad." Moral categories of what is bad and what is acceptable, what constitutes corruption and what doesn't, are ambivalent and context-specific, not only among different people, but also within the moral chart of individuals. As Rigi notes in an extensive descriptive analysis of the various practices of gift-exchange, bribes, corruption and extortion within, and outside, personal relations in Kazakhstan, people often have an ambiguous and context-specific perception of these practices and the degree to which they, freely or unwillingly, are engaging in them. "While the status of blat ${ }^{5}$ and of small bribes disguised as gifts is ambiguous, large bribes and extortions and the Mafia are classified as outright corruption" (Rigi 2004:114, cited in Prado 2004).

William, a young man in his 30s working for Fundacomunal, tried to explain his idea of the different categories of corruption to me. For him, the basic form of corruption was el rebusque - meaning that people, for example, stole small things on the workplace and resold it privately, or inflated their traveling expenses when they handed them to their employers. This kind of rebusque wasn't really corruption in his view, but rather a necessary way of making ends meet, in which most people would engage without thinking of it as corruption. He argued that "ordinary" low-level salaries very rarely covered basic needs and that in one way or the other, people had to earn some extra once in a while. In that sense, the rebusque 
can been seen as filling the void between real salaries and the cost of living, which converts the practice into a structurally deficient part of the economy reflecting economic inequalities and the conditions of the working poor. The other corruption category he identified was that of politicians and businesses engaging in corrupt deals - that was, in his opinion, "corruption" pure and simple. Here there were no "excuses" other than greed. I asked him how he would categorize stealing money within the communal councils destined to community projects. This he classified as robbery. I asked him if someone would classify this as a rebusque rather than stealing, and he said that, no, "they are rats, they are stealing from their own people." In William's view then, el rebusque was, to some extent, acceptable and perceived as an act of need, while corruption was "pure robbery" - an act of greed and low morality.

\section{Corruption High and Low}

The ethnographic focus of this chapter is on the interface between popular sector communities and public institutions. However, I want to reiterate that these practices should in no way be taken as indication of a culture of poverty (Lewis 1966) in the form of social pathologies particular to certain social groups. As Zinn (2005) has noted, "those who are in a subaltern class position more often bear the stigma of label associated to corruption; whereas business and political elites can make use of connection capital" (Zinn 2005:239). Tales of lower-level corruption should therefore always be seen in relation to the broader political-economic organization, whereby the wealthy, through their relationships with political elites as well as their positions, assets and networks, are capable of using the ambivalences of legal norms and their class shield against law enforcement to amass wealth through dubious means. By that, I do not mean to condone corruption at "lower levels" - and as this section has shown, corruption within communal councils was by and large morally condemned-but to emphasize that an interpretation of social norms and practices in this context has to be intrinsically understood in relation to broader socio-political organizations as well as relationships of hierarchies and power.

As Pardo notes "the experience of corruption may be a corollary of the reach of the state. It may also be testimony to an internalization of its norms and values" (Pardo 2004:10). The state in Venezuela was historically shaped by crude power plays and the amassment of wealth, long before the concept of corruption was invented. However, as processes of state formation throughout the twentieth century were mirrored in the 
imagery of democracy and rule of law, corruption also emerged as a symbolladen socio-political concept in public life, gradually bringing out in sharp relief the contrast between "democratic ideals" flaunted by the elites and their actual practices. It is telling that Carlos Andrés Pérez was ultimately removed from power on corruption charges - though it should be added that his removal also reflected internal power plays in Acción Democrática (Trinkunas 2002) and the need for a scapegoat to take the blame for the legitimacy crisis that concerned the political casts at large.

However, Pérez's public fall evidences that "corruption" has, since long ago, been internalized in the public imagery as an "evil" and that it is a pervasive phenomenon extremely difficult to root out. I often spoke with community activists about what could be done to change things at state level, and many pointed to the necessity of reforming the ethos and organization of public offices from within. "Opportunity makes thief," one man said, and the "informal" state organization of fiefdom, networks of loyalties and gate keepers provide ample space for dishonest practices. At the same time, the practices of corruption were also explained as the outcome of the continuous power of existing state personnel, engaging in corrupt behavior since long back. One man explained this by recounting how SAIME ${ }^{6}$ (previously called DIEX ${ }^{7}$ and later $\mathrm{ONIDEX}^{8}$ ), the public office issuing passports and identity cards, had been reformed. SAIME used to be a public institution that was notorious for corruption, including "selling" fake identity cards and routinely charging fees for issuing documents. Moreover, as DIEX, the office allegedly had the habit of "forgetting" or simply not bothering to issue identity cards to popular sector citizens who were not adeco supporters, which meant that those citizens were not allowed to vote.

However, in 2003, as a part of Misión Identidad, ${ }^{9}$ the institution was taken over by the political scientist and lawyer Hugo Cabezas, aided by young people from Frente Fransisco de Miranda. After Misión Identidad was completed, the institution was reformed and only received online applications (avoiding personal contact with public officers). Many of the existing personnel, basically adeco supporters, retired. The result, according to my interlocutor, was that SAIME was now one of the public institutions that functioned properly and was known for having low levels of corruption.

However, as we have explored previously in this book, most state institutions in the Chávez era were a corollary of new and old personnel, networks and organizations, permeated by an ambivalent co-existence of old "state practices," and new ideological visions and political ideals. Moreover, the deeply ingrained imagery of the state as a site through which one can amass 
wealth ("ponme donde hay") still held sway over how new cohorts of state servants exercised their role and the social expectations inscribed into such positions. Rosa, whom we got to know in Chap. 3, recounted that she had been asked by a neighbor: "Why do you continue to work when you have two children working for the government?" Rosa told me this to exemplify la mentalidad (the mentality) that circulates among many people. If you have children working for the government they are able to pull strings in order to provide the things you need. And as government workers they are well positioned for getting their hands in the honey jar one way or the other.

However, I suggest that it is a highly fictitious intellectual exercise to separate corruption at state level from corruption in other spheres of society (be it the business community or any other public or private institution or enterprise). Corruption is part of multi-vocal bundles of social practices that are thriving upon ambivalent norms and values, socially codified strategies for regulating supply and demand and historical formations of power and privileges.

Thus, in essence, we need to understand how templates of corruption are historically dense and intimately intertwined with broader processes of state formation and social relations, forming part of a broader set of discourses and practices embodying and articulating social and political moralities. As this chapter has demonstrated, the Bolivarian discourse harbored on the one hand, a profound tension between everyday realities of social and political life, and on the other, ideals and visions of a different moral order that could engender a more just and harmonious society.

Throughout the past three chapters, I have explored how the Bolivarian process under Chávez was characterized by attempts to find a new moral terrain from which the Bolivarian process' political goals could be realized. Epitomized by phrase "Che's New Man," linkages were made between individual behavior, goals and values, and the emergence of a new social order at large. What loomed large in these discourses were denouncements of individual and collective behavioral traits such as individualism, greed, corruption, reckless consumption and dishonesty. However, throughout these chapters, I have tried to highlight the broader processes and structures underpinning these discourses and social struggles, tracing them back to particular forms of post-colonial state formation, social and political dynamics emerging through the development of the oil economy, and local versions of global discourses of modernity, class identities and development. 
The discussions sustained through these pages show that Venezuela's experience with extractive capitalism engendered very particular political practices, social experiences and cultural idioms. In people's vernacular narratives, we find that they draw direct linkages between "macro processes" and their individual life experiences. "Extractive capitalism" or "neoliberalism" was not only theoretical and descriptive concepts, but also deeply communal and embodied social experiences codified in local idioms and narratives. In the next and final chapter, I will offer some concluding reflections on how we may understand and interpret the interlinkages between local experiences of popular struggle in the Caracas barrios, Venezuela's oilfuelled development trajectories before and during the Bolivarian process, and global structures and processes. We will start with a snapshot of a large concentration in the city center of Caracas, the year before Chávez died.

\section{Notes}

1. This is the more commonly used short version. The full version is: "Con los adecos se vive mejor, porque roban y dejan robar mientras que los copeyanos roban pa' ellos solos" [with the adecos one is better off, they steal and let others steal as well, while the copeyanos only steal for themselves].

2. Temporary projects is the translation of campamiento, which literally means camp (like summer camp). However in Venezuela it can also refer to the habit of starting short-time project/campaigns, for example a political campaign launched solely for electoral propaganda.

3. Interview, anonymous member of National Assembly, spring 2011.

4. The phrase "una nación de cómplices" [a nation of accomplices] was first used by the writer Tómas Lander in 1836 in an attempt to describe how all the stakeholders at the time engaged in the same destructive and amoral dynamics, bleeding the country economically, politically and morally. The phrase is often used in the contemporary discourse to underscore that "everyone" is corrupted in one way or the other.

5. Blat is the local term for using personal relations for obtaining goals.

6. The office has been called Servicio Administrativo de Identificación, Migración y Extranjería (SAIME) since 2007.

7. In 1963 named Dirección de Identificación y Extranjería (DIEX).

8. In 2004 DIEX was re-named Oficina Nacional de Identificación y Extranjería (ONIDEX).

9. Misión Identidad was a program put in motion by the government in 2003 after recognizing that large parts of the poor and rural urban population didn't have identity cards. The mission was organized in mobile outreach units whereby people from Frente Fransisco de Miranda traveled across the country issuing identity cards. 


\section{BIBLIOGRAPHY}

Bourgois, Philippe. 2003. In Search of Respect: Selling Crack in El Barrio. Cambridge: Cambridge University Press.

Cabrujas, José Ignacio. 1996 [1995]. La viveza criolla. Destreza, mínimo esfuerzo o sentido del humor. Caracas: Cátedra Fundación Sivensa-Ateneo. http://es. slideshare.net/lmballesteros/la-viveza-criolla. Accessed February 20, 2017.

Coronil, Fernando. 1997. The Magical State: Nature, Money, and Modernity in Venezuela. Chicago: University of Chicago Press.

- 2011. State Reflections. The 2002 Coup against Hugo Chavez. In The Revolution in Venezuela. Social and Political Change under Chavez, ed. T. Ponniah and J. Eastwood. Cambridge, MA: David Rockefeller Center for Latin American Studies, Harvard University.

Derham, Michael. 2010. Politics in Venezuela. Explaining Hugo Chávez. Oxford, Bern, Berlin, Bruxelles, Frankfurt am Main, New York, Wien: Peter Lang.

Díaz, Eleazar R. 2006. La corrupción en Venezuela. Aporrea, August 6. http:// www.aporrea.org/actualidad/a24200.html. Accessed February 20, 2017.

Díaz, Octavina. 2009. La Corrupción en la Cuarta y la Quinta República. Aporrea, September 17. http://www.aporrea.org/contraloria/a86644.html. Accessed February 20, 2017.

Ellner, Steve. 2009. A New Model with Rough Edges: Venezuela's Community Councils. NACLA Report on the Americas 42 (3) (May/June): 11-14.

García, Luis Britto. 2013. Para vencer la corrupción. Aporrea, August 25. http:// www.aporrea.org/contraloria/al72305.html. Accessed February 20, 2017.

Gledhill, John. 1994. Power and Its Disguises. Anthropological Perspectives on Politics. London: Pluto Press.

- 2004. Neoliberalism. In A Companion to the Anthropology of Politics, ed. D. Nugent and J. Vincent. Malden, MA: Blackwell Publishing.

Gupta, Akhil. 1995. Blurred Boundaries: The Discourse of Corruption, the Culture of Politics, and the Imagined State. In The Anthropology of the State. A Reader, ed. A. Sharma and A. Gupta. Oxford: Blackwell Publishing.

Haller, Dieter, and Chris Shore. 2005. Corruption. Anthropological Perspectives. London and Ann Arbor, MI: Pluto Press.

La Nueva. 2010. Editorial: El auge de la viveza criolla. La Nueva, December 26. http://www.lanueva.com/Sociedad-/440601/el-auge-de-la-viveza-criolla. html. Accessed February 20, 2017.

Lazar, Sian. 2008. El Alto, Rebel City. Self and Citizenship in Andean Bolivia. Durham and London: Duke University Press.

Lewis, Oscar. 1966. La Vida: A Puerto Rican Family in the Culture of Poverty. San Juan and New York. New York: Random House.

MacLennan, Carol. 2005. Corruption in Corporate America: Enron-Before and After. In Corruption. Anthropological Perspectives, ed. C. Shore and D. Haller. London and Ann Arbor, MI: Pluto Press. 
Pardo, Italo. 2004. Introduction. Corruption, Morality and the Law. In Between Morality and the Law. Corruption, Anthropology and Comparative Society, ed. I. Pardo. Aldershot: Ashgate Publishing.

Pierce, Steven. 2006. Looking Like a State: Colonialism and the Discourse of Corruption in Northern Nigeria. Comparative Studies in Society and History 48 (4): 887-914.

Prato, Giuliana. 2004. 'The Devil Is Not as Wicked as People Believe, Neither Is the Albanian': Corruption between Moral Discourse and National Identity. In Between Morality and the Law: Corruption, Anthropology and Comparative Society, ed. I. Prato. Aldershot: Ashgate Publishing.

Rigi, Jakob. 2004. Corruption in Post-Soviet Kazakhstan. In Between Morality and the Law: Corruption, Anthropology and Comparative Society, ed. I. Pardo. Aldershot: Ashgate Publishing.

Scott, James. 1985. Weapons of the Weak. Everyday Forms of Peasant Resistance. New Haven and London: Yale University Press.

Shore, Cris. 2005. Culture and Corruption in the EU: Reflections on Fraud, Nepotism and Cronyism in the European Commission. In Corruption: Anthropological Perspectives, ed. C. Shore and D. Haller. Ann Arbor, MI: Pluto Press.

Trinkunas, Harold. 2002. The Crisis in Venezuelan Civil-Military Relations: From Punto Fijo to the Fifth Republic. Latin American Research Review 37 (1): $41-76$.

Wiarda, Howard. 1971. Law and Political Development in Latin America: Toward a Framework for Analysis. The American Journal of Comparative Law 19 (3): $434-463$.

Zinn, Dorothy Louise. 2005. Afterword-Anthropology and Corruption: The State of the Art. In Corruption. Anthropological Perspectives, ed. D. Haller and C. Shore. London and Ann Arbor, MI: Pluto Press.

Open Access This chapter is distributed under the terms of the Creative Commons Attribution 4.0 International License (http://creativecommons.org/ licenses/by/4.0/), which permits use, duplication, adaptation, distribution and reproduction in any medium or format, as long as you give appropriate credit to the original author(s) and the source, provide a link to the Creative Commons license and indicate if changes were made.

The images or other third party material in this chapter are included in the chapter's Creative Commons license, unless indicated otherwise in a credit line to the material. If material is not included in the chapter's Creative Commons license and your intended use is not permitted by statutory regulation or exceeds the permitted use, you will need to obtain permission directly from the copyright holder.

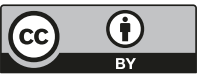




\section{Final Reflections: Understanding the "Revolutionary Petro-State"}

It was May 1, 2011. I was standing on the bridge connecting the stateowned Hotel Alba Caracas (formerly Hilton Caracas) and the apartment hotel, Residencias Anauco in Parque Central (Central Park), where many of the Cuban collaborators in government missions and international political guests were living. The bridge is located on the eastern end of Avenida Bolívar, a two-kilometer-long eight-lane motor road connecting the southern end of Parque Central with the tunnels leading to Plaza O'Leary at the eastern end of El Silencio. Avenida Bolívar was filled with people dressed in red as far as the eye could see. Chávez was talking from a stage at the far end of the avenue. I didn't know it yet, but it would be the last time I saw him alive.

The march had started earlier that morning in Gato Negro, in Catia-a popular neighborhood par excellence. Avenida Sucre, which connects Plaza Sucre at the entrance to Caracas from the motorway Caracas-La Guaira, and to the city center with the presidential palace, was closed off. The Guardia Civil (civil guard) was directing traffic and the crowds that were pouring in from all the connecting streets. I had arrived by motor bike along with a friend. I wanted to take pictures and needed to be able to move quickly in order to find good shots. People had already started to march toward Avenida Bolívar and we trawled between the crowds alongside the road. Caraqueños are used to motorbikes; they move slowly (sometimes not at all) at the sound of a honk without even stopping their conversations. The marchers were carrying posters and banners 


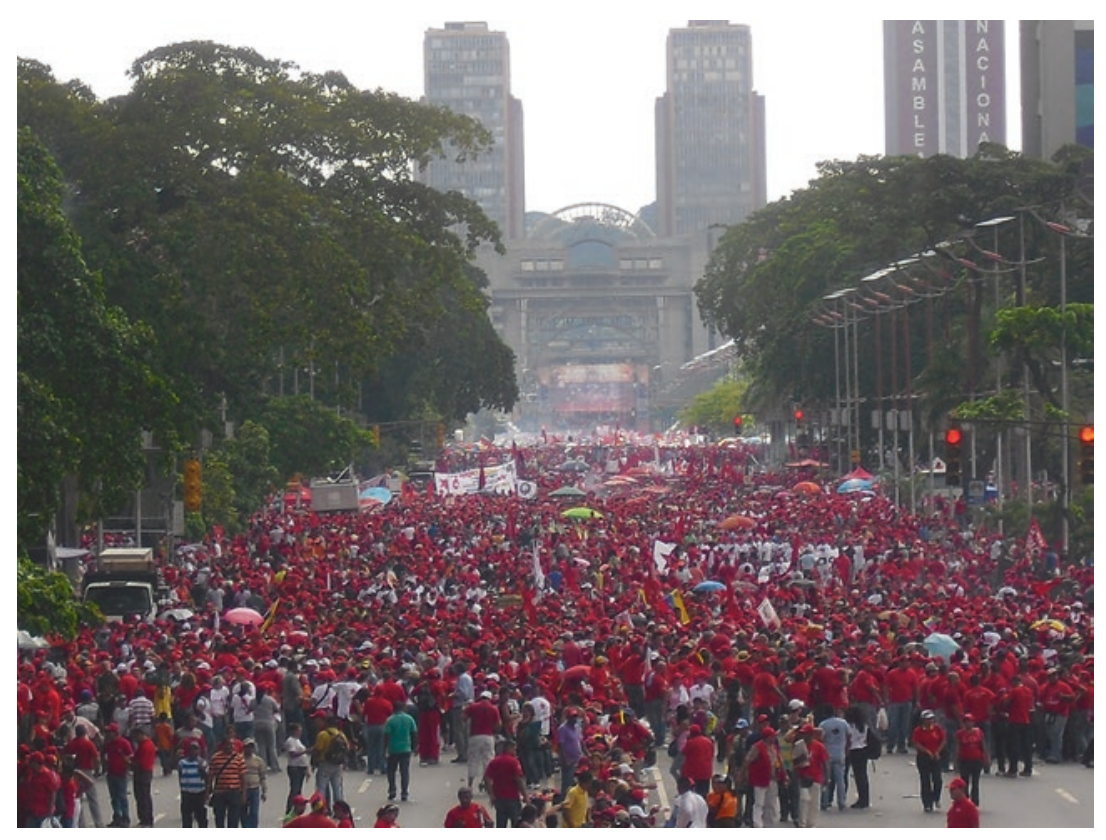

Photo 11.1 March and public meeting with President Chávez in Avenida Bolívar, May 1, 2011. Photo by the author

reading: "Female workers constructing socialism!" "For those who want patria, let's go with Chávez!" "The revolution vindicates the Venezuelan working class. Long live the Revolution!" "Mothers from San Juan," "FETRAELEC. Workers' Control," "PDVSA oil workers fighting tooth and nail. Fatherland, socialism or death, we will win!" Someone had made a giant inflatable balloon portraying the globe, featuring a white arm and a black arm embracing South America, and the communist insignia hammer and sickle hovering over the North Pole. A man was holding a large handwritten poster saying: "The revolution is carried in the heart to die for her and not in the mouth to live off her." A group of oil workers with red helmets on their heads were playing drums. A giant sound system on the back of a truck filled the air with revolutionary jingles, while a group of women, dressed in traditional Venezuelan costumes, danced in the middle of the march. The air was filled with music, shouting and laughter as the 
crowd moved slowly toward Avenida Bolívar where Chávez a few hours later would enter the stage.

Over the years, I had participated in many mass gatherings just like this one. Pre-electoral rallies, post-electoral celebrations, May 1, commemorations of the defeat of the 2002 coup. Giant marches and celebrations filling the western city center with men, women and children of all ages, dressed in red, carrying posters and banners, dolls or art work. Street vendors selling food and drinks, bottles passing around, and revolutionary music blasting out on stages, loudspeakers and giant television screens. Often many hours would pass before Chávez actually appeared, but that did not matter. People chatted with family and friends, meeting old political allies and making new ones. When Chávez finally arrived a giant roar would fill the air, and people calmed down to hear him talk. However, as his speeches tended to be long, they quickly resumed talking as they listened. When his voice reached a crescendo to underline a point, people cheered, whistled and shouted comments of support, occasionally breaking out in collective chanting of political slogans.

This vignette represents, in many ways, the incarnation of a populist rally, the perfect aesthetics of a popular revolution uniting el pueblo and the state. Javier Auyero's much acclaimed monograph Poor People's Politics. Peronist Survival Networks and the Legacy of Evita (2000) opens with a similar epigraph from a Peronist march in Argentina celebrating Perón's birthday. As he argues, the marches only represent a small part of the overall "set of material practices and symbolic constructions that constitute [Peronisms] organizing principles" (Auyero 2001:207). Auyero succinctly illustrates that the political practices and representations of Peronism must be understood in the context in which they are lived; as the product and everyday re-production of a political idea as much as a political party structure, grounded in structural inequalities, socio-cultural politics of difference, social relationships, and real-life needs. Toward the end of his account, Auyero makes reference to a reflection made by Wacquant:

The intellectual bias which entices us to construe to world as a spectacle, as a set of significations to be interpreted rather than as concrete problems to be solved practically, is more profound and more distorting that those rooted in the social origins and locations of the analysis in the academic field, because 
it can lead us to miss entirely the differentia spesifica of the logic of practice. (Auyero 2001:207, emphasis in original)

The warning against construing the world as a spectacle that this quote alludes to is pertinent to our context. The symbolic universe uniting the popular sectors and Chávez was indeed often spectacular. Chávez's charismatic qualities accentuated his symbol-laden rhetoric, his allusions to national icons, historical genesis and destined future, and his invocations of grand visions that were to be materialized through the unity of the state and el pueblo. Symbolic dramaturgy and material change were tied together, forming part of what $\mathrm{I}$, in this book, have called a Bolivarian space. This space was a political, ideological and social universe uniting the Chávez government and its supporters, carved out of the backbone of a dense political narrative portraying the Bolivarian process as the historical moment of vindication for Venezuela's marginalized people. These are the most obvious surface expressions of Chávez's rule, those that could be publicly observed and critically dissected, framed through a photogenic political snapshot epitomized by crowds dressed in red collectively cheering Chávez's flamboyant speeches.

However, throughout this book, I have sought to go beyond this surface image. My aim has been to gain a deeper understanding not only of the historical background and political processes leading to Chávez's rise to power and subsequent enormous popularity among his supporters, but more importantly, the social histories, political agencies and lived experiences emerging from within the popular sectors that accompanied him throughout his rule. As I argued, if we want to gain a proper understanding of the form, expressions and evolution of the Bolivarian process we need to understand Venezuelan history, both in the past and in the present, through the lens of the popular sectors. At the time of Chávez's rise to power, the Venezuelan political and economic system was severely exhausted and stripped of legitimacy. Contra-factual history could surely have provided a range of different scenarios of what would have happened if Chávez hadn't been the person to seize power at such a schismatic moment. However, it was Chávez who arrived on the political scene at this juncture in Venezuelan history, representing, to paraphrase Victor Hugo, an idea whose time had come. This historical convergence would not only create paradigmatic shifts in Venezuela, but also leave its mark on the Latin American political landscape at large. 


\section{UNDERSTANDING IDEOLOGY}

Throughout this book, I have sketched out a broad picture of historical interpretations and identity politics, ideologies and worldviews as conceptualized from the point of view of popular sector activists. Recognizing the plasticity of historical interpretations, I have strived to connect these emic articulations to broader historical trajectories, processes and structures, showing how dominant history and ideology are diverging from those emerging from subalternity. Unfamiliar worldviews and ideologies may often seem incomprehensible to external observers. However, as Nugent notes:

The conditions according to which the organization by people of material and social relationships may be formulated differently (re-cognized) over time means that [the] concept of ideology articulates a fundamentally historical phenomenon, revealing growing contradictions in social relations. (Nugent 1993:36)

Thus, the diverging ideological directions, and indeed worldviews, that have polarized the Venezuelan polity since long back, taking new forms and meaning after Chávez's first electoral victory in 1998, need to be interpreted within a framework that takes into account how social relationships have been intrinsically formed in relation to material and structural configurations of society at large. Different social groups in Venezuela base their identity politics, interest regimes and ideological frameworks on radically different life paths and lifeworlds. Simultaneously, these different features are molded upon a range of shared symbolic and material signifiers. This creates the potential of transcending existing differences, at the same time as the social gulf makes it difficult to build comprehension and mutual recognition.

\section{Fissures Through History}

As I have shown throughout this book, the Venezuelan polity has been molded by racial- and class-based fissures throughout its entire history as a nation, each political epoch giving different form and significance to the social imaginaries that these differences engender. The end of the oil-smoothed development paradigm in the 1980s, the enactment of neoliberal reforms as well as violent government responses to popular protests shattered the myth of national unity that had prevailed since Acción 
Democrática consolidated its social hegemony in 1959. As Lander notes, the birth of electoral democracy in 1959 had engendered expectations in the populace about imminent social development and national progress (Lander 2005:33).

A "modern" integrated society appeared possible in a not too distant future. A political culture of "national harmony" and its corresponding multiclass political party organization achieved hegemony. The self-image of an inclusive, egalitarian, and racially democratic society became dominant. Optimism prevailed. The thesis of Venezuelan exceptionalism took firm hold. (Lander 2005:26)

The Puntofijismo hegemony was underwritten by habitual "everyday" violence against the poor, violent persecution of radical opposition, as well as skillful containment of organized labor and the peasantry (Ellner 2008; Ciccariello-Maher 2013). On the surface, social harmony prevailed. However, toward the end of the 1970s, this myth started to crack. Poverty and inequalities increased drastically. Historical divisions, and more recent forms of social exclusions that political dominant discourse and imageries had glossed over, started to surface (Lander 2005:26). As Lander states: "An increasingly divided society took shape in Venezuela" (Lander 2005:26), accompanied by an increasing sense of insecurity. The wealthier classes started to build fences and place bars around their living spaces, and the poor started to increasingly become portrayed as "the dangerous classes" in the media (Lander 2005:27), featuring racist overtones that had never been previously uttered in public. Society seemed to fall apart from within:

These processes of exclusion, segregation, and fragmentation led to socioeconomic decay-especially in the cities—and to the decomposition of the traditional mechanisms and forms of socialization, particularly the family, school and work. (Lander 2005:27)

Meanwhile, the political classes were increasingly becoming stripped of legitimacy. Not only were they caught up in a range of political scandals and endemic corruption, but the enactment of neoliberal reforms was also by many viewed as a betrayal of national interests and of the very populace. El Caracazo in 1989 dealt the final blow to the imagery of national harmony. Not only had racial- and class-based tensions become a public 
truth, but the state's readiness to maintain its control through the use of force made it clear that the popular sectors were collectively viewed as antagonistic to the Venezuelan polity. When Chávez led the attempt to topple Carlos Andrés Pérez in 1992, the coup was widely perceived by the popular classes and beyond as a legitimate means to dispose of a political system and ruling class that had exhausted its legitimacy.

As I have suggested throughout this book, it is paramount to understand this prolonged socio-political drama not only as the origin of the profound polarization and social antagonisms in Venezuelan society, but also as constitutive of the ways in which the Bolivarian process gradually became cast as a political crusade aimed at restoring national dignity and sovereignty through founding a new moral, social and political order. Significantly, the popular classes, who not only had borne the main burden of the socio-economic crisis but had also been cast as the nation's "others," became within the Bolivarian process cast as el pueblo soberano, a synthesis of the refounding of the nation and the redemption of its people.

As Lander (2005) notes, this discourse was radically and divergently interpreted by different social groups. For the upper and middle classes, as well as for many of the country's intellectuals, who were oriented toward "consumption patterns, value orientations, and enjoyment of the 'modern' global good life" (Lander 2005:33), this discourse was alienating. Indeed, the Bolivarian political orientation-away from Westernized imageries of modernity, Western political alliances as well as its allusions to nationalism-was interpreted as "an anachronism in a globalizing world, a return to unfeasible and historically Third World postures" (Lander 2005:33). For the poor however, the reorientation toward traditional and popular Venezuela, the reinterpretation of the nation's founding myth, and a pledge of solidarity to other Third World countries and oppressed peoples became a pathway into a process of "cultural decolonialization" (Lander 2005:34). At the same time, it became an ideological and social platform for their political integration into the state and nation body.

\section{Venezuela's Rise and Fall}

It is vital to comprehend this socio-political genealogy not as a process confined to national dynamics alone, but rather as constitutive of broader processes of post-colonial state formations and configurations of global 
capitalism in the twentieth century. The formation of the Venezuelan state and political economy was essentially a product of its position as a resource-exporting country (Coronil 1997; Karl 1997). Indeed, the Venezuelan state came into being as an entity, real and imagined, through this very process:

It was only when it was transformed into a mediator between the nation and foreign oil companies that the state acquired the capacity and financial resources that enabled it to appear as an independent agent capable of imposing its domination over society. (Coronil 1997:4)

Yet, this process was more than a question of political state-making. Through the nation's entanglement into the global production of center-periphery relations, Venezuela became a site of convergence for locally appropriated ideas of modernity and progress molded upon Western notions of universal progress. As Coronil (1997) notes:

I have tried to keep in mind that the process of state formation in Venezuela is part of a global project of modernity that claims for itself a singular universality, rationality, and morality that depends in the subordination, exclusion or destruction of alternative forms of sociality, rationality, and values. (Coronil 1997:17)

This perspective is important to capture in order to appreciate the deeper script behind the rise and fall of the Venezuelan dream for the future in the latter part of the twentieth century - and indeed the imagery of the Venezuelan nation-state. As for Zambia's copper belt, succinctly analyzed by Ferguson (1999), the rise to modernity and progress for the nation and its people alike seemed to be so close during the heydays of developmentalist optimism in the 1960s and 1970s. Yet, this bubble of optimism was founded on structural fragility and illusions of national independence. Venezuela's attempt to make a "great leap" into First World modernity through industrial development and modernization projects were based on mortgaging the nation's oil rents to Western powers in return for loans. As Escobar (1995) has shown, these processes of economic restructuring and loan agreements were part of a broader ideological global process of "a total restructuring of 'underdeveloped' countries" (Escobar 1995:4). In terms of real politik, this shift was spurred by a "need to expand and deepen the market of U.S. 
products abroad, as well as the need to find new sites for the investment of U.S. surplus capital" (Escobar 1995:32). When this bubble burst, Venezuela's peripheral and subordinate status became evident. From then on, the indebted nation was subordinate to the dictums of Western capital interest and development ideologies, mediated through the IMF. It is a paradox of almost epic proportions:

Ironically, a state that was constituted as a national state through its control over petroleum was undone when it used the nation's subsoil to underwrite loans to finance a project of industrial development designed to end the nation's dependence on petroleum. (Coronil 1997:392)

The fall from grace was twofold: not only was the Venezuelan state stripped of its grandeur and illusions of sovereignty in the attempt-however truncated, jagged and inadequately executed-to try to free itself from the grip of oil and to better integrate into the world economy, but this downfall also perpetuated the country's subordination to the point that, in spite of possessing great riches, the space for domestic economic and political maneuvering became even smaller. Over time, Venezuela became a hostage of its own riches, trapped in a global web of exploitative and unequal power relations.

\section{The Devil's Excrement}

Oil has always been conceived of as Venezuela's Achilles' heel, her nemesis. "We are drowning in the Devil's Excrements." The words were uttered by Juan Peréz Alfonzo, the Venezuelan lawyer, diplomat and politician, minister for mines and hydrocarbons during Betancourt's second government (1959-1964), and one of the founders of OPEC. His words have been repeated over and over again ever since. In 2011, the Venezuelan Central Bank (BCV) reprinted a new edition of Alfonzo's book, first published in 1976, with the same title. Arturo Uslar Pietri, who was the first one to coin the phrase "sow the oil," predicted, since early on, that oil would change and determine everything in Venezuela, leading the country astray on the path of doom:

"Petroleum is the fundamental and basic fact of the Venezuelan destiny. It presents to Venezuela today the most serious national problems that the nation has known in its history. It is like the minotaur of ancient myths, in 
the depths of its labyrinth, ravenous and threatening. "The vital historical theme for today's Venezuela can be no other than the productive combat with the minotaur of petroleum. "Everything else loses significance. Whether the Republic is centralist or federalist. Whether the voters vote white that is, $\mathrm{AD}$ ] or any other color. Whether they build aqueducts or not. Whether the University is open or not. Whether immigrants come or don't come. Whether schools are built or not built. Whether workers earn five bolívares or fifteen bolívares. All those issues lack meaning. "Because they are all conditioned, determined, created by petroleum. They are all dependent and transitory. Dependent and transitory. "Petroleum and nothing else is the theme of Venezuela's contemporary history. (Uslar Pietri 1972, cited in Ewell 1984:61)

In Betancourt's speech to congress in 1975, as he was presenting the draft for the new Petroleum Law, he opened with the words from E.H. Davenport and S.R. Cooke's 1923 book The Oil Trusts and the Anglo-American Relations: "It is a much disseminated opinion that oil awakes the worst passions, awakes a more devouring greed in the men of business than the passion of Gold, and incites the men of the State to follow Maquiavellian plans" (Betancourt 1975:10, author's translation from Spanish). When Carlos Andrés Pérez resigned from his second term, he stated that "I raised the hopes of our people and built confidence on our country, but there was too much that I could not do, that I, with all the oil money, could not change" (Karl 1997:72).

It is not only in Venezuela that oil has been imbued with powers of destruction of the minds of men and obstruction of the paths of politics. Oil wealth is surrounded by a distinct mythos (Watts 1999:2); it is an enigma just as much as a material substance. Consider Watts's (1999) descriptions of one of the inherent characteristic of oil, which he terms Petro-Fetishism/Petro-Magic (the El Dorado effect). By this, he means "oil as a world of illusions. People become wealthy without effort; fabulous wealth and fiscal madness [...]. The ephemerality of money-boom to bust, here today gone tomorrow; wealth which scorches the fingers, signifies the loss of the soul" (Watts 1999:7-8). Oil is associated with criminality, violence, corruption, the crude exercise of power and the destruction of people, nations and nature alike (Watts 1999). "Graft and thuggishness are its defining characteristics. And it is to be expected then that in an age of unprecedented denationalization and market liberalization, the mad scramble to locate the next petrolic El Dorado continues unabated" (Watts 1999:1). 


\section{The Heterogeneity of Resource Wealth}

The combined political and emotive volatility associated with oil is accentuated in the symbol-laden scholarly concept of the "resource curse," associated with a historical determination and an inescapable faith, while also being steeped in economistic, macro-oriented and technocratic evaluations of resource management or lack thereof. The theory of the resource curse, which started gaining prominence in the 1980s (Rosser 2006:557), postulates that an abundance of natural resources, rather than promoting social development and economic growth, engenders a host of political and social problems in developing countries. High levels of poverty, civil war, thwarted economic growth, authoritarian rule and high levels of conflict are all characteristics that have been linked to resource wealth (Rosser 2006). However, anthropologists have repeatedly criticized this concept, arguing for the need to seek more subtle and nuanced understanding of social and political processes emerging from resource extraction (see Watts 1999, 2004; Sawyer 2004; Coronil 1997; Mitchell 2011; Logan and McNeish 2012).

In line with this view, I have in this book sought for ethnographically based understandings of the socio-cultural processes and political dynamics that resource wealth engenders. This exploration has been structured around three parallel, but interrelated, lines of inquiry. First, an inquiry into the lives of the popular sectors in the shadows of the nation's oil wealth, cut off both from its material benefits and from the symbols of progress that it engendered. By drawing on collective memories and political narratives from the era of Puntofijismo, I teased out a broad imagery of the escalation of rage and grievances stemming from this symbolic-material deprivation, showing how the underbelly of the Magical State was concretely experienced as suffering, violence and deprivation. Simultaneously, I showed how these experiences engendered a massification of protest from within the popular sectors, paving the way for Chávez's electoral victory in 1998. Within the Bolivarian discourse, the narrative of social exclusion and marginalization engendered an ideological ethos of the state's duty to repay its social debts to the poor through the redistribution of the nation's wealth. These promises were materialized through a range of political reforms and social programs directed to the poor, interlinked with broader ideological notion of popular power and el pueblo soberano. Concurrently, policies for political participation as well as other arenas for social mobilization became platforms for a reconfiguration of the rela- 
tionship between the popular sectors and the state. Through inquiring into these platforms, I have sought a broader understanding of how the cultural-political emancipation of the formerly marginalized sectors of the population was connected to their claims to finally take part in the nation's oil wealth.

However, as I have shown, the leap from this political ethos into political realities was fraught with conflicts and tensions. In that process, the state became cast as a battlefield between the old, antagonistic state, to borrow Derham's (2010) apt formulation, and the vision of a new Bolivarian state capable of converting the ethos of social justice and political participation into reality. The Chávez government inherited a massive state bureaucracy and a state culture that continued to reproduce itself through ingrained social and political practices under the tutelage of a reform-bent government. This illustrates the difficulties of fomenting institutional change at the level of the state, as well as the theoretical fragility of posing a dichotomist divide between "the state" and society at large. The role of the state apparatus as both an instigator and an impediment for political change under the Chávez government must be understood not only as a series of institutional practices and dynamics, but also as the "stickiness" of imageries of the state as a site of power and privileges which through its day-to-day procedures and practices reproduced exclusionary mechanisms vis-à-vis the popular sectors.

At the same time, I have shown how the political ethos of popular power within the Bolivarian space, as well as the concrete policies and reforms accompanying it, opened up what I called a hybrid space of politics from above and politics from below. By drawing on the symbolic repertoire within the Bolivarian discourse and seizing the political opportunity windows emanating from the government, the popular sectors found leverage for including popular agencies, modes of organization and cultural politics into the languages of the state (Blom Hansen and Stepputat 2001). These processes were part and parcel of everyday politics in the interface between the popular and the state. Meetings between state bureaucrats, public functionaries, political figures and community activists were constituted as politically charged arenas where the resilience of state power and historical exclusionary practices were tested and challenged. Importantly, these processes did not reflect a schismatic divide between the inside and the outside of the state. Rather, different interests, ideologies, received 
wisdoms and personal ambitions were converging both within and outside the state apparatus, reflecting the real-life messiness of a society in the midst of a process of transformation, as well as the uncertain outcomes of these processes.

Finally, I turned to the historical legacy and the spectacles of oil in different socio-cultural imaginaries, converging in the narratives of the immoralities and destructiveness of Venezuelans' historical experience with extractive capitalism. I showed how the Bolivarian space harbored a profoundly moral discourse about the necessity of refounding a social and moral order that was lost to greed, immoral consumption, corruption and social fragmentation, and how these social "vices" were attributed to the ways in which oil wealth was (unequally) distributed and consummated within the socio-political body. Moral personhood and political integrity had been undermined by the triumph of hedonistic rent-seeking, exacerbated by the ways in which Western templates of modernity had become locally absorbed as the conspicuous display of money. These discourses of moralities also played into political polarization at large. Through their support for, and association with, modernity "US style" and the global capitalist system undercutting it, the opposition and their supporters were cast as the "bearers" of this cultural heritage. In turn, these value systems were cast as the anti-thesis to the form of national identity, social transformation and cultural reappreciation of autochthonous socialities and traditions that the Bolivarian process sought to engender.

At the same time, struggles to create a new moral order were hampered from within the popular social body itself. Individualized dreams of consumption, sectarian and personal ambitions and desires for wealth were constantly present in the day-to-day processes of founding a new collective social order revolving around collective consumption at the grassroots level. I have suggested that these tensions reflect the inherent difficulties of fomenting social and political change, and the inherent contradictions of the Bolivarian process itself. Different ideological templates, social practices and political imaginaries were converging in a multitude of sites throughout society, expressed through symbolic as well as material practices in everyday life. This reflects not only the enduring legacy of oil (Tinker Salas 2009). Fundamentally, it also reflects of Venezuela's embeddedness in global economies of capital as well as global economies of desires and wants. 


\section{A DifFerent Curse?}

The formation of a Venezuelan oil economy produced a distinct process of class formation; "the middle class grew proportionally larger than the working class: an inverted class pyramid propped up on petro-dollars" (Karl 1997:82-83). This would later determine the political priorities of subsequent governments (toward favoring middle-class and elite interests), the dominant socio-cultural norms and values reflected in "official" society, the untenable growth of the state bureaucracy and the relative limited political attempts to cater to the popular classes. These socio-political patterns proved successful, on the surface at least, until the crisis hit the country in the beginning of the 1980s.

As Coronil has emphasized, a fundamental breach in Venezuelan political trajectories occurred with the liberalization of markets and the rise of financial speculative capitalism in the 1980s (Logan and McNeish 2012:17). This form of economic restructuring took place in many countries in the Global South at the time. However, the particular ways in which it occurred and the ways in which it was socially interpreted in Venezuela were essentially molded by the country's oil wealth. Not only was the domestic productive economy already gravely underdeveloped (see Karl 1997), exacerbating inclinations to speculation and rent-seeking that had already existed within the political economy for a long time. But the symbolic interpretations attributed to money, wealth and national patrimony produced a new political imaginary of deep fissures between the socio-political national body and the natural body of oil harbored in its soil. In other words, Venezuelans had always known that they were rich. Even the poor had a vague sense of this albeit they perceived oil as something out of their reach. However, a close reading of history and social imaginaries connected to this epoch indicates that the fundamental crisis occurred because, on the one hand, the country was told that it was broke and that "people" had to tighten their belt even more, and on the other, massive amounts of capital were circulating among those who were positioned to grab their loot.

These intertwined processes created a sense of fundamental rupture between the nation's wealth, the political system and its representatives, and the people. The political leaders were perceived as pillagers, devoid of national sentiments or social responsibility toward their people. As Coronil writes:

Since the traditional elite was implicated in the financial crisis, the [previous distinction between reputable businessmen and unprincipled speculators] became untenable. As a depositor in the Metropolitan Bank who lost his 
savings stated bitterly about the trust he had placed in the bank's board of directors: "They were members of the country's business aristocracy. They were the best names. Honest people, people with blue blood." But now he regarded them as people who "don't have a country." As he puts it: their country is money. (Coronil 1997:382)

This quote is extremely powerful because it alludes to a profound sense of deceit. The symbolic bond between the guardians of wealth and its legitimate beneficiaries was ripped apart, only later to appear in Bolivarian discourse as a narrative of betrayal against both the nation and its populace.

As Gledhill notes, "a popular imaginary of the potential link between national resource sovereignty and social justice has had powerful historical effects" (Gledhill 2008:57). The fact that this trope is increasingly at the center of (often violent) negotiations between states and their citizens, indicates that there is a profoundly diverging perception between how oil has been managed, structured and conceptualized through global energy markets and domestic political systems, and the ways in which "the people" vest natural resources with a whole range of socio-cultural properties linking together citizenship, state governance, nationhood, belonging and justice. In essence, natural resources are embedded in a much broader economy of values, subjected to strong emotive reactions and association, including grievances and rage. The contemporary global economic paradigm of high-noon capitalism and accelerated resource extraction does to a very little extent allow these different scales of values into its epistemological frameworks of reference. This is also why the Bolivarian process as well as the so-called Pink Tide harbored a profound contestation of the intertwined doxa of resource wealth, liberal democracy and market economy.

Venezuela was in many ways the first country to challenge the hegemony of "there is no alternative" at the level of the state at the turn of the century. I have often wondered why this was the case and whether it was just a historical coincidence or something particular to Venezuela propelling the process of political rupture and change of horizons. Empirically, there might not be a good answer to this question. But on a more philosophical level, I ponder over whether this occurred because Venezuela, more than most other countries, believed so hard it was on the fast-track toward a bright future. Being the best, brightest and most exceptional "pupil" in the Latin American liberal democratic class, the country was praised by foreign leaders, intellectuals, academics and journalists as the exception to the rule of Third World unruliness. Blessed by providence, 
Venezuela possessed enormous resources that would guarantee development, prosperity and modernity. When its fall from grace eventually happened, it came hard. And the poor, who had never benefited from the virtues neither of the country's democratic system nor abundance of wealth, realized that it was very unlikely that they ever would. They were tired of being regarded as collateral damage in a system that both alienated and impoverished them. As Derham (2010) notes about Venezuela as well as other countries steeped in similar conflicts:

After a century or more of experiments with "democracy" and politicians ... the conditions in which the majority has to live are simply unacceptable ... why should they be expected to waste yet another twenty years of their life, waiting for the consolidation of a system that has never worked before? (Derham 2010:278)

It is with this background and with the twist and turns in history that followed that Chávez gained power, and the Bolivarian process gradually took shape, in parallel with the nascent leftist and subaltern political current elsewhere at the continent.

\section{Changing the Question}

Centuries ago, Rousseau wrote: "Do you want the state to be solid? Then make the wealth spread as small as you can; don't allow rich men or beggars" (Rousseau 2010 [1762]). ${ }^{2}$ I suggest that if there is one central issue that can be learned from Venezuelan history of the past 50 years, it is that the country's trajectories confirm the insight offered by Rousseau. The countries that are often referred to as exceptions to the rule of the so-called resource curse, Canada and Norway, are also the countries that enjoy some of the lowest inequality levels in the world and highest indices of human development. Of course, the reasons for this are as complex as the reasons for why other oil-rich countries have struggled. Fundamentally, these are countries located in the Global North, subjecting them to entirely different development processes, demographic formations, socio-political dynamics and modes of integration into the global (political) economy than those characterizing post-colonial countries.

However, perhaps there is still a deeper lesson to be learned if we manage to reconceptualize the resource curse: that is, not as a matter of wealth, but fundamentally as a matter of unequal distribution of wealth. Posing 
the analytical challenge that way we are better equipped to ask new questions and find new answers. The resource curse thesis is often presented as if there were an inherent quality in resource wealth that generated poverty and social inequalities. However, as the first author to associate Venezuela with the term "petro-state" also makes clear in her book: "The question is not whether oil is a blessing or a curse, but rather what specific type of political and economic development trajectory it encourages and whom it benefits" (Karl 1997:235).

As this book has sought to illuminate, inequality in Venezuela is the result of complex dynamics between historical, structural and geo-political trajectories, as well as political priorities and configurations of power and dominance. As Chávez's time in power showed, this legacy can also be contested and poverty can be significantly reduced over a relatively short period of time. It is thus paramount to recognize that resource wealth does engender great possibilities in reducing poverty-depending on whether there is political will to exploit or create structural opportunity windows.

Nonetheless, as this empirical inquiry into the everyday realities of the Chávez government's political reforms has suggested, poverty reduction is not at all only a matter of technocratic decision-making processes and policy designs. Rather, it is also interwoven in broader economic, social, cultural, political and institutional dynamics and processes, making it paramount to capture the complexities at play and the frequent un-predictability of its outcomes. As the Venezuelan example clearly shows, efforts to reverse decades or centuries of structural inequalities and entrenched poverty are part of a highly complex and messy "broader whole," playing not only into political struggles over resources, power and control at large, but also intersecting with culturally contingent political practices and social imaginaries.

Moreover, we need to recognize that "domestic" relations of poverty and opulence, wealth and wants, power and subordination are molded through global processes, responding to global schisms between the winners and losers of the contemporary global political-economic model and the social imaginaries accompanying it. As Coronil notes:

While the international elite moves easily between even more insecure domestic enclaves of privilege and the metropolitan centers, the majority is restricted to an increasingly impoverished social environment palpably marked by abandonment and neglect $[\ldots]$. The tragedy of modernity is that its promise of universal progress cannot be fulfilled in the terms in which it has been cast. (Coronil 1997:385) 
As the example from Venezuela and other countries caught up in struggles over natural resources illustrate, the tangible yet ephemeral qualities of oil make it a "perfect screen" for projecting this "tragedy of modernity" and the structural divisions undercutting it. However, I will reiterate that these structural divisions are not natural, but man-made. Moreover, they are not only political in a narrow sense, but essentially ideological and epistemological.

We therefore have to bring the question of resource wealth together with broader questions about how the hegemonic power inherent to the political economy of capital can be replaced or supplemented with a broader economy of values. Essentially this implies, as was indicated by Escobar (2010), a quest to carve out a vision of alternative modernities or futures which are not founded upon the myth of limitless economic growth; a myth that in its core relies on the myth of limitless extraction of natural resources. If we accept this postulate, it follows that redefining modernity and redefining the production, management and distribution of oil intrinsically constitute two sides of the same coin. As Coronil succinctly states:

Oil has helped mold a highly stratified and ecologically unsound world shaped in the image of disconnected peoples and things that have in common their separation from each other and from the history that engendered them. If modernity is a process characterized by the incessant, obsessive and irreversible transformation of a world splintered into distinct entities, then the effects of an oil production and consumption reflects the spirit of modernity. (Coronil 1997:18)

These insights brings into sharp relief that the challenges that Venezuela has faced and is still facing are not confined to the country alone. Rather, in essence, it is a challenge with global scope, reaching into the essence of how we have organized, molded and imagined our common world for the better part of the last century.

\section{Final Afterthoughts}

The Venezuela that is explored in this book is very different from the Venezuela of today as I write these words in February 2017. Chávez is dead, the Maduro government has record-low support, the opposition has increased its electoral strength, the political conflict has hardened, the country's institutional weaknesses have become even more evident, oil prices have fallen drastically, the economy is in shambles, poverty levels 
have increased, social indicators have radically worsened, and many grassroots activists have become de-mobilized. In short, Venezuela is a country in deep crisis. The international context is also different. The so-called Pink Tide is by most accounts and measures officially over. In its place, many predict the pendulum with swing toward a right-wing neoliberal model once more, as is already happening in Argentina and Brazil. I have deliberately not made references to the current situation throughout my analysis of the Chávez years in this book, because I wanted to focus on the ethnographic present as it unfolded at the time. However, I believe that the developments in Venezuela after Chávez's death highlight the importance of an analytical focus emphasizing historical continuity and ruptures as I have pursued in this book. In many ways, the thin red lines through Venezuelan history are put into even sharper relief in the current moment. The country's vulnerability in the face of global oil markets and geo-politics, its reliance on oil and imports, the political costs of the historical legacy of playing the political field as a zero-sum game, the continuous absence of a social contract between the nation's different classes, the continuous weak institutionalizing capacity of the Venezuelan state, the continuous politization of public institutions: as Buxton rightly notes, there were a lot of historical continuities that gave cause for concern already during the Chávez years (Buxton 2011:xx-xxi). Seen together, this legacy, in combination with Chávez's death, the political turbulence that followed, the global fall in oil prices and its effects upon the domestic economy, fostered in many ways a perfect storm for which the outcome is yet to be seen. The challenges now facing scholars of Venezuela is to inquire into exactly how these historical and contemporary processes were intertwined and playing out, as well as examining how the Bolivarian process has engendered new social, cultural and political legacies that will shape the country's future development trajectories.

Because of the current crisis, it is tempting to dismiss the political processes in Venezuela in the Chávez epoch as merely "old wine in a new bottle," as another resource-cursed economic cycle, or as yet another leftist utopia turned sour. However, if we do so, we are not only committing an academic fallacy in failing to take into account the fine-grained dynamics between historical and time-specific social, economic, political and cultural processes in the course of the Bolivarian process. We are also missing an opportunity to learn something about political struggle and social change more broadly.

As Geertz noted: "Social change will not be hurried and it will not be tamed" (Geertz 2004:578). And if there is one thing that is truly 
global at this moment, it is that control over resources, power and politics are increasingly being fought over on a multitude of arenas. In large parts of Europe, young people are now faced with the prospect of being worse off throughout their life time than their parents. The promise of an ever-brighter future-of a fast-track to a prosperous, developed highmodernity - is increasingly fading even in its place of origin. Faced with an aggravated loss of control over their lives and livelihoods and an increasing closure of spaces for de facto democratic influence, people are taking to the street with a combination of anger, resignation and desperation. Only time will tell how these processes will evolve, and toward what that anger, resignation and desperation will be directed. But for that exact reason we should pay close attention to Venezuela. Throughout the past decades they have faced a democratic and economic breakdown spurred by the volatility and supremacy inherent in global capitalist logic and the monopolization of power and resources at both international and national level. Popular rage and protest was followed by the election of Chávez, to a displacement of hegemonic power, aggravated political polarization, and the search of an alternative political horizon and model. This, in the end, did neither prove sustainable nor tenable, and now, as indicated, after Chávez's death Venezuela has entered into yet another époque whose future trajectory and outcome are yet to be seen.

Venezuela's social and political trajectories are particular to their context and history, but these processes tell us something about how global, national and local processes are intimately intertwined and ultimately inseparable. Anthropologists' focus on the local, "the human condition, down here on earth" (Lambek 2011:199) is an important and indispensable corrective to the grand political and economic narratives that remove people's real lives, struggles and hardships from the equation. Our task is to tell the stories about how people, everywhere and all the time, are struggling and trying to shape their own life histories, though often not in conditions of their own choosing, to paraphrase Marx. This book has told such a story, and innumerable similar stories are unfolding in this very moment, right in front of our eyes.

\section{Notes}

1. This is my translation from Spanish as I was unable to get a hold of the English original. In Spanish the quote reads: "Es una opinión muy difundida que el petroleo despierta las peores pasiones, hace nacer en los hombres 
de negocio una avidez más devoradora que la pasión de Oro e incita a los hombres de Estado a seguir designios maquiavélicos" (Betancourt 1975:10). 2. Social Contract, book 2, ch. 11, footnote 16 .

\section{BIBLIOGRAPHY}

Auyero, Javier. 2001. Poor People's Politics. Peronist Survival Networks and the Legacy of Evita. Durham and London: Duke University Press.

Betancourt, Romulo. 1975. Venezuela. Dueña de su petroleo. Caracas: Catalá Centauro Editores.

Buxton, Julia. 2011. Foreword. Venezuela's Bolivarian Democracy. In Venezuela's Bolivarian Democracy. Participation, Politics and Culture under Chávez, ed. D. Smilde and D. Hellinger. Durham and London: Duke University Press.

Ciccariello-Maher, George. 2013. We Created Chávez: A People's History of the Venezuelan Revolution. Durham and London: Duke University Press.

Coronil, Fernando. 1997. The Magical State: Nature, Money, and Modernity in Venezuela. Chicago: University of Chicago Press.

Derham, Michael. 2010. Politics in Venezuela. Explaining Hugo Chávez. Oxford, Bern, Berlin, Bruxelles, Frankfurt am Main, New York, Wien: Peter Lang.

Ellner, Steve. 2008. Rethinking Venezuelan Politics. Class, Conflict, and the Chávez Phenomenon. Boulder and London: Lynne Rienner Publishers.

Escobar, Arturo. 1995. Encountering Development. The Making and the Unmaking of the Third World. Princeton, NJ: Princeton University Press.

- 2010. Latin America at a Crossroad. Cultural Studies 24 (1): 1-65.

Ewell, Judith. 1984. Venezuela. A Century of Change. London: C. Hurst \& Company. Ferguson, James. 1999. Expectations of Modernity. Myths and Meanings of Urban Life on the Zambian Copperbelt. Berkeley: University of California Press.

Geertz, Clifford. 2004. What Is a State If It Is Not a Sovereign? Reflections on Politics in Complicated Places. Current Anthropology 45 (5): 577-593.

Gledhill, John. 2008. "The People's Oil": Nationalism, Globalization, and the Possibility of Another Country in Brazil, Mexico, and Venezuela. FocaalEuropean Journal of Anthropology 52: 57-74.

Hansen, Thomas Blom, and Finn Stepputat. 2001. Introduction: States of Imagination. In States of Imagination. Ethnographic Explorations of the Postcolonial State, ed. T.B. Hansen and F. Stepputat. Durham and London: Duke University Press.

Karl, Terry Lynn. 1997. The Paradox of Plenty. Oil Booms and Petro-States. Berkeley: University of California Press.

Lambek, Michael. 2011. Catching the Local. Anthropological Theory 11 (2): 197-221.

Lander, Edgardo. 2005. Venezuelan Social Conflict in a Global Context. Latin American Perspectives 32 (2): 20-38. 
Logan, Owen, and John-Andrew McNeish. 2012. Rethinking Responsibility and Governance in Resource Extraction. In Flammable Societies. Studies on the Socio-economics of Oil and Gas, ed. J.-A. McNeish and O. Logan. London: Pluto Press.

Mitchell, Timothy. 2011. Carbon Democracy: Political Power in the Age of Oil. London: Verso.

Nugent, Daniel. 1993. Spent Cartridges of Revolution. An Anthropological History of Namiquipa, Chihuahua. Chicago and London: The University of Chicago Press.

Rosser, Andrew. 2006. The Political Economy of the Resource Curse: A Literature Survey. Working Paper 268, Institute of Development Studies, University of Sussex, Brighton.

Rousseau, Jean Jacques. 2010 [1762]. The Social Contract or Principles of Political Right. Trans. G.D.H. Cole. San Antonio, TX: The Constitution Society.

Salas, Miguel Tinker. 2009. The Enduring Legacy. Oil, Culture, and Society in Venezuela. Durham and London: Duke University Press.

Sawyer, Suzana. 2004. Crude Chronicles: Indigenous Politics, Multinational Oil, and Neoliberalism in Ecuador. Durham: Duke University Press.

Uslar, Arturo P. 1972. De una a otra Venezuela. Caracas: Monte Avila.

Watts, Michael. 1999. Petro-Violence: Some Thoughts on Community, Extraction, and Political Ecology. Working Paper 99-1, Institute of International Studies, University of California, Berkeley.

- 2004. Anatomies of Community: Some Thoughts on Geography, Resources and Empire. Transactions of the Institute of British Geographers 29 (2): 195-216.

Weyland, Kurt. 1999. Neoliberal Populism in Latin America and Eastern Europe. Comparative Politics 31 (4): 379-401.

Open Access This chapter is distributed under the terms of the Creative Commons Attribution 4.0 International License (http://creativecommons.org/ licenses/by/4.0/), which permits use, duplication, adaptation, distribution and reproduction in any medium or format, as long as you give appropriate credit to the original author(s) and the source, provide a link to the Creative Commons license and indicate if changes were made.

The images or other third party material in this chapter are included in the chapter's Creative Commons license, unless indicated otherwise in a credit line to the material. If material is not included in the chapter's Creative Commons license and your intended use is not permitted by statutory regulation or exceeds the permitted use, you will need to obtain permission directly from the copyright holder.

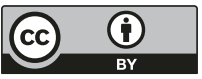




\section{BIBLIOGRAPHY}

Abrams, Philip. 1988 [1977]. Notes on the Difficulties of Studying the State. In The Anthropology of the State. A Reader, ed. A. Sharma and A. Gupta. Oxford: Blackwell Publishing.

Aguiar, Asdrúbal. 2007. Los cinco motores de la Revolución en Venezuela. Analitica. http://www.analitica.com/opinion/opinion-nacional/los-cinco-motores-de-larevolucion-en-venezuela/. Accessed February 20, 2017.

Al Jazeera. 2009. US 'Likely Behind' Chavez Coup. Al Jazeera, September 21. http://www.aljazeera.com/news/americas/2009/09/200992116049879437. html. Accessed February 20, 2017.

Ali, Tariq. 2013. Tariq Ali: Hugo Chávez and Me. The Guardian, March 16. http://www.theguardian.com/world/2013/mar/06/hugo-chavez-and-metariq-ali. Accessed February 20, 2017.

Alonso, Ana María. 1994. The Politics of Space, Time and Substance: State Formation, Nationalism and Ethnicity. Annual Review of Anthropology 23 (1): 379-405.

Alvarez, Sonia E., Evelyn Dagnino, and Arturo Escobar. 1998. Cultures of Politics, Politics of Cultures: Re-Visioning Latin American Social Movements. Boulder: Westview Press.

Alvarez, Rosángel, and María Pilar García-Guadilla. 2011. Controlaría social y clientelismo: La praxis de los consejos comunales en Venezuela. Politeia 34 (46): 175-207.

Amnesty International. 1980. Amnesty International Annual Report 1980. London: Amnesty International Publications. https://www.amnesty.org/en/documents/ poll0/0003/1980/en/. Accessed February 20, 2017.

Anderson, Benedict. 1983. Imagined Communities: Reflections on the Origin and Spread of Nationalism. London: Verso.

(C) The Author(s) 2017

I.Å. Strønen, Grassroots Politics and Oil Culture in Venezuela, DOI 10.1007/978-3-319-59507-8 
Antillano, Andrés. 2005. La lucha por el reconocimiento y la inclusión en los barrios populares: La experiencia de los comités de tierra urbana. Revista Venezolana de Economía y Ciencias Sociales 11 (3): 205-218.

Appadurai, Arjun. 1988. The Social Life of Things. Commodities in Cultural Perspective. Cambridge: Cambridge University Press.

- 1990. Disjuncture and Difference in the Global Cultural Economy. Public Culture 2 (2): 1-24.

Apter, Andrew. 1993. "Festac for Black People": Oil Capitalism and the Spectacle of Culture in Nigeria. Paper delivered at the Presenting the Past Workshop, Northwestern University, Evanston, April 16.

Arditi, Benjamin. 2007. Politics on the Edges of Liberalism. Difference, Populism, Revolution, Agitation. Edinburgh: Edinburgh University Press.

Arnett, Peter. 1978. Oil Boom-Town. Conspicuous Consumption on a Grand Scale. The News and Courier, May 21. http://news.google.com/newspapers?n $\mathrm{id}=2506 \& \mathrm{dat}=19780521 \& \mathrm{id}=$ w5 JAAAAIBAJ $\&$ sjid $=$ fgwNAAAAIBAJ $\& p g=1422,4549248$. Accessed January 2, 2014.

Auyero, Javier. 2001. Poor People's Politics. Peronist Survival Networks and the Legacy of Evita. Durham and London: Duke University Press.

- 2011. Patients of the State: An Ethnographic Account of Poor People's Waiting. Latin American Research Review 46 (1): 5-29.

Auyero, Javier, Pablo Lapegna, and Fernanda Paga Poma. 2009. Patronage Politics and Contentious Collective Action: A Recursive Relationship. Latin American Politics and Society 51 (3): 1-31.

Azzelini, Dario. 2013. The Communal State: Communal Councis, Communes and Workplace Democracy. NACLA 46 (2): 25-30.

— n.d. La revolución bolivariana: "o inventamos o erramos." Claves para leer el proceso de transformación social venezolano. Revista Herramienta 36. http://www.herramienta.com.ar/revista-herramienta-n-36/la-revolucionbolivariana-o-inventamos-o-erramos-claves-para-leer-el-proces. Accessed February 20, 2017.

Bauman, Zygmunt. 2012. Times of Interregnum. Ethics and Global Politics 5 (1): $49-56$.

BBC. 2007. Chavez's Colorful Quotations. www.bbc.co.uk, November 12. http:// news.bbc.co.uk/2/hi/7090600.stm. Accessed February 20, 2017.

- 2012. In Depth: Media in Venezuela. www.bbc.co.uk, October 3. http:// www.bbc.co.uk/news/world-latin-america-19368807. Accessed February 20, 2017.

Betancourt, Romulo. 1975. Venezuela. Dueña de su petroleo. Caracas: Catalá Centauro Editores.

Bhatt, Keane. 2014 [2013]. The New York Times on Venezuela and Honduras: A Case of Journalistic Misconduct. NACLA, May 8. https://nacla.org/article/ new-york-times-venezuela-and-honduras-case-journalistic-misconduct. Accessed February 20, 2017. 
Blom Hansen, Thomas, and Finn Stepputat. 2001. States of Imaginations. Ethnographic Explorations of the Postcolonial State. Durham and London: Duke University Press.

Bourdieu, Pierre. 1979. Distinctions. A Social Critique of the Judgment of Taste. Cambridge, MA: Harvard University Press.

- 1986. The Forms of Capital. In Handbook of Theory and Research for the Sociology of Education, ed. J. Richardson. New York: Greenwood.

Bourgois, Philippe. 2001. Culture of Poverty. In International Encyclopedia of the Social and Behavioral Sciences, ed. Neil J. Smelser and Paul B. Baltes. Amsterdam: Elsevier Science Ltd.

- 2002. Ethnography's Troubles and the Reproduction of Academic Habitus. Qualitative Studies in Education 15 (4): 417-420.

- 2003. In Search of Respect. Selling Crack in El Barrio. Cambridge: Cambridge University Press.

—. 2004. US Inner-City Apartheid: The Contours of Structural and Interpersonal Violence. In Violence in War and Peace. An Anthology, ed. N. Scheper-Hughes and P. Bourgois. Oxford: Blackwell Publishing.

- 2006. Foreword. In Engaged Observer. Anthropology, Advocacy and Activism, ed. V. Sanford and A. Angel-Ajani. New Brunswick, New Jersey and London: Rutgers University Press.

Brouwer, Steve. 2011. Revolutionary Doctors. How Venezuela and Cuba Are Changing the World's Conception of Health Care. New York: Monthly Review Press.

Bruce, Ian. 2008. The Real Venezuela. Making Socialism in the 21st Century. London: Pluto Press.

Bubandt, Nils. 2006. Sorcery, Corruption, and the Dangers of Democracy in Indonesia. The Journal of the Royal Anthropological Institute 12 (2): 413-431.

Buxton, Julia. 2001. The Failure of Political Reform in Venezuela. Aldershot, Burlington, USA, Singapore and Sydney: Ashgate.

—. 2011. Foreword. Venezuela's Bolivarian Democracy. In Venezuela's Bolivarian Democracy. Participation, Politics and Culture under Chávez, ed. D. Smilde and D. Hellinger. Durham and London: Duke University Press.

Bye, Vegard. 1979. Nationalization of Oil in Venezuela: Re-Defined Dependence and Legitimization of Imperialism. Journal of Peace Research 16 (1): 57-78.

Cabrujas, José Ignacio. 1996 [1995]. La viveza criolla. Destreza, mínimo esfuerzo o sentido del humor. Caracas: Cátedra Fundación Sivensa-Ateneo. http://es. slideshare.net/lmballesteros/la-viveza-criolla. Accessed February 20, 2017.

Caldeira, Teresa. 2001. City of Walls. Crime, Segregation, and Citizenship in São Paulo. Berkeley: University of California Press.

Canache, Damarys. 2002. From Bullets to Ballots: The Emergence of Popular Support for Hugo Chavez. Latin American Politics and Society 44 (1): 69-90.

Chacín, Neritza Alvardo. 2003. La atención a la pobreza en Venezuela del "Gran Viraje" a la "V República," 1989-2002. Revista Venezolana de Análisis de Coyuntura 9 (2): 111-150. 
Chatterjee, Partha. 2004. The Politics of the Governed. Reflections on Popular Politics in Most of the World. New York: Colombia University Press.

Ciccariello-Maher, George. 2013. We Created Chávez: A People's History of the Venezuelan Revolution. Durham and London: Duke University Press.

- 2016. Building the Commune. Radical Democracy in Venezuela. London and New York: Verso.

Cohen, Anthony. 1985. The Symbolic Construction of Community. London and New York: Routledge.

Collier, Ruth Berins, and Samuel Handlin. 2009. Reorganizing Popular Politics. Participation and the New Interest Regime in Latin America. Pennsylvania: The Pennsylvania State University Press.

Collier, Paul, and Anke Hoeffler. 1998. On Economic Causes of Civil War. Oxford Economic Papers 50 (4): 563-573.

- 2000. Greed and Grievances in Civil War. Washington, DC: World Bank, Development Research Group.

- 2005. Resource Rents, Governance, and Conflict. The Journal of Conflict Resolution 49 (4): 625-633.

Comaroff, Jean, and John L. Comaroff. 1987. The Madman and the Migrant: Work and Labor in the Historical Consciousness of a South African People. American Ethnologist 14 (2): 191-209.

Comaroff, John L., and Jean Comaroff. 1990. Goodly Beasts, Beastly Goods: Cattle and Commodities in South Africa. American Ethnologist 17 (2): 195-216.

- 1997. Postcolonial Politics and Discourses on Democracy in Southern Africa: An Anthropological Reflection on African Political Modernities. Journal of Anthropological Research 53 (2): 123-146.

Comaroff, Jean, and John L. Comaroff. 1999. Occult Economies and the Violence of Abstraction: Notes from the South African Postcolony. American Ethnologist 26 (2): 279-303.

-2001. Naturing the Nation: Aliens, Apocalypse and the Postcolonial State. Journal of Southern African Studies 27 (3): 627-651.

Constitution of the Bolivarian Republic of Venezuela. 1999. Article 70. http:// www.venezuelaemb.or.kr/english/ConstitutionoftheBolivarianingles.pdf. Accessed February 20, 2017.

Cooke, Bill, and Una Kothari. 2001. Participation: The New Tyranny? London and New York: Zed Books.

Coronil, Fernando. 1996. Beyond Occidentalism: Beyond Geohistorical Categories. Cultural Anthropology 11 (1): 51-87.

- 1997. The Magical State: Nature, Money, and Modernity in Venezuela. Chicago: University of Chicago Press.

- 2008. Chávez's Venezuela. A New Magical State? In ReVista. Harvard Review of Latin America, vol. 8. Cambridge, MA: David Rockefeller Center for Latin American Studies, Harvard University. 
2011. State Reflections. The 2002 Coup against Hugo Chavez. In The Revolution in Venezuela. Social and Political Change under Chavez, ed. T. Ponniah and J. Eastwood. Cambridge, MA: David Rockefeller Center for Latin American Studies, Harvard University.

Coronil, Fernando, and Julie Skurski. 2006. States of Violence. Ann Arbor: University of Michigan Press.

Corrales, Javier. 2001. Strong Societies, Weak Parties: Regime Change in Cuba and Venezuela in the 1950s and Today. Latin American Politics and Society 43 (2): 81-113.

Corrales, Javier, and Michael Penfold. 2007. Social Spending and Democracy. The Case of Hugo Chávez in Venezuela. LASA Forum 38 (1): 20-22.

- 2011. Dragon in the Tropics. Hugo Chávez and the Political Economy of Revolution in Venezuela. Washington, DC: Brookings Institution Press.

Correo del Orinoco. 2012. Vicepresidente: Barrio Adentro ha realizado más de 745 millones de consultas médicas. Correo del Orinoco, April 16. http://www. correodelorinoco.gob.ve/nacionales/vicepresidente-barrio-adentro-harealizado-mas-745-millones-consultas-medicas/. Accessed February 20, 2017.

- 2013. Sierra Maestra tiene su estadio de fútbol. Correo del Orinoco, October 21. http://www.ciudadccs.info/?p=491568. Accessed December 20, 2013.

Creed, Gerald. 2004. Constituted through Conflict: Images of Community (and Nation) in Bulgarian Rural Ritual. American Anthropologist 106 (1):56-70.

D'Elia, Yolanda, and Luis Fransisco Cabezas. 2008. Las Misiones Sociales en Venezuela. Caracas: Instituto Latinoamericano de Investigaciones Sociales (ILDIS).

D'Elia, Yolanda, and Cristyn Quiroz. 2010. Las Misiones Sociales: ¿Una alternativa para superar la pobreza? Caracas: Instituto Latinoamericano de Investigaciones Sociales (ILDIS).

Dagnino, Evelina. 2005. Meanings of Citizenship in Latin America. ISD Working Paper, Institute of Development Studies, University of Sussex, Brighton.

Debord, Guy. 1967. The Society of the Spectacle. New York: Zone Books.

Derham, Michael. 2010. Politics in Venezuela. Explaining Hugo Chávez. Oxford, Bern, Berlin, Bruxelles, Frankfurt am Main, New York, Wien: Peter Lang.

Díaz, Octavina. 2009. La Corrupción en la Cuarta y la Quinta República. Aporrea, September 17. http://www.aporrea.org/contraloria/a86644.html. Accessed February 20, 2017.

Douglas, Mary, and Baron Isherwood. 1996. The World of Goods. Towards an Anthropology of Consumption. London and New York: Routledge.

Duno-Gottberg, Luis. 2006. Mi Negra: Los nuevos colores de un populismo de la derecha. Aporrea. http://www.aporrea.org/actualidad/a26414.html. Accessed February 20, 2017.

- 2009. Social Images of Anti-Apocalypse: Bikers and the Representation of Popular Politics in Venezuela. Contracorriente 6 (2): 144-172. 
. 2011. The Colour of Mobs. Racial Politics, Ethnopopulism, and Representation of the Chávez Era. In Venezuela's Bolivarian Democracy. Participation, Politics and Culture under Chávez, ed. D. Smilde and D. Hellinger. Durham and London: Duke University Press.

Elizalde, Rosa Miriam, and Luis Báez. 2004. Chávez Nuestro. Havana: Casa Editora Abril.

Ellner, Steve. 1986. The MAS Party in Venezuela. Latin American Perspectives 13 (2): 81-107.

- 1989. Organized Labor's Political Influence and Party Ties in Venezuela: Accion Democratica and Its Labor Leadership. Journal of Interamerican Studies and World Affairs 31 (4): 91-129.

- 1995. Venezuelan Revisionist Political History, 1908-1959: New Motives and Criteria for Analyzing the Past. Latin American Research Review 30 (2): 91-121.

- 1996. Political Party Factionalism and Democracy in Venezuela. Latin American Perspectives 23 (3): 87-109.

- 1999. Obstacles to the Consolidation of the Venezuelan Neighborhood Movement: National Cleavages. Journal of Latin American Studies 31 (1): 75-97.

- 2002. The "Radical" Thesis on Globalization and the Case of Venezuela's Hugo Chávez. Latin American Perspectives 29 (6): 88-93.

- 2003. The Contrasting Variants of the Populism of Hugo Chávez and Alberto Fujimori. Journal of Latin American Studies 35 (1): 139-162.

- 2005. The Emergence of a New Trade Unionism in Venezuela with Vestiges from the Past. Latin American Perspectives 32 (2): 51-71.

- 2009. A New Model with Rough Edges: Venezuela's Community Councils. NACLA Report on the Americas 42 (3) (May/June): 11-14.

- 2010. Rethinking Venezuelan Politics. Class, Conflict, and the Chávez Phenomenon. Boulder and London: Lynne Rienner Publishers.

- 2011. Venezuela's Social-Based Democratic Model: Innovations and Limitations. Journal of Latin American Studies 43 (3):421-449.

Ellner, Steve, and Daniel Hellinger. 2003. Venezuelan Politics in the Chávez-Era. Class, Polarization and Conflict. Boulder, CO: Lynne Rienner Publishers.

Ellner, Steve, and Fred Rosen. 2002. Venezuela's Failed Coup, the US' Role and the Future of Hugo Chávez. Foreign Policy in Focus, June 1. http://fpif.org/ venezuelas_failed_coup_the_us_role_and_the_future_of_hugo_chaacutevez/. Accessed February 20, 2017.

Ellner, Steve, and Miguel Tinker Salas. 2005. Introduction. Latin American Perspectives 32 (2): 5-19.

Englund, Harri, and James Leach. 2000. Ethnography and the Meta-Narrative of Modernity. Current Anthropology 41 (2): 225-248.

Escobar, Arturo. 1995. Encountering Development. The Making and the Unmaking of the Third World. Princeton, NJ: Princeton University Press. 
2010. Latin America at a Crossroad. Cultural Studies 24 (1): 1-65.

Escobar, Arturo, and Sonia Álvarez. 1992. The Making of Social Movements in Latin America. Identity, Strategy and Democracy. Boulder, San Francisco and Oxford: Westview Press.

Espina, Gioconda, and Cathy A. Rakowsky. 2010. Waking Women Up? Chavez, Populism and Venezuela's "Popular" Women. In Gender and Populism in Venezuela: Passionate Politics, ed. K. Kampwirth. University Park, PA: Penn State University Press.

Ewell, Judith. 1984. Venezuela. A Century of Change. London: C. Hurst \& Company.

Fassin, Didier, and Paula Vasquez. 2005. Humanitarian Exception as the Rule: The Political Theology of the 1999 Tragedia in Venezuela. American Ethnologist 32 (3): 389-405.

Ferguson, James. 1994. The Anti-Politics Machine: Development, Depolitization and Bureaucratic Power in Lesotho. Minneapolis and London: University of Minnesota Press.

- 1999. Expectations of Modernity. Myths and Meanings of Urban Life on the Zambian Copperbelt. Berkeley: University of California Press.

Ferguson, James, and Akhil Gupta. 2002. Spatializing States: Towards an Ethnography of Neoliberal Governmentality. American Ethnologist 29 (4): 981-1002.

Fernandes, Sujatha. 2007. Barrio Women and Popular Politics in Chávez's Venezuela. Latin American Politics and Society 49 (3): 97-127.

- 2010. Who Can Stop the Drums? Urban Social Movements in Chávez' Venezuela. Durham and London: Duke University Press.

Figueroa, Federico Brito. 1967. La población y la estructura social de Venezuela en las primeras décadas del Siglo XIX. Bulletin Hispanique 69 (3-4): 347-364.

Flama. Liberación y Petroleo. 2011. Entrevista al Profesor Carlos Mendoza Potellá: Interview by the Editorial Team. Flama. Liberación y Petroleo, AprilJune. Caracas: Fundación Editorial El Perro y la Rana.

Foucault, Michel. 1991. Governmentality. In The Anthropology of the State. A Reader, ed. A. Sharma and A. Gupta. Oxford: Blackwell Publishing.

Fourcade, Marion, and Kieran Healy. 2007. Moral Views on Market Society. Annual Review of Sociology 33: 285-311.

Frente Fransisco de Miranda. n.d. Que es el Frente. http://frentefranciscodemirandasocopo.blogspot.no/p/quienes-somos.html. Accessed February 20, 2017.

Friedman, Jonathan. 1994. Consumption and Identity. London and New York: Routledge.

Fukuyama, Francis. 1992. The End of History and the Last Man. New York, London, Toronto, Sydney: Free Press.

Fung, Archon, and Erik Olin Wright. 2003. Deepening Democracy. Institutional Development in Empowered Participatory Governance. London and New York: Verso. 
García, Luis Britto. 2013. Para vencer la corrupción. Aporrea, August 25. http:// www.aporrea.org/contraloria/a172305.html. Accessed February 20, 2017.

Garcia-Guadilla, María Pilar. 2005. The Democratization of Democracy and Social Organizations of the Opposition: Theoretical Certainties, Myths, and Praxis. Latin American Perspectives 32 (2): 109-123.

- 2007. Ciudadanía y autonomía en las organizaciones sociales bolivarianas: Los Comités de Tierra Urbana como movimientos sociales. Cuadernos de Cendes 24 (66): 47-73.

- 2008a. La praxis de los Consejos Comunales en Venezuela: ¿Poder popular o instancia clientelar? Revista Venezolana de Economia y Ciencias Sociales 14 (1): $125-151$.

- 2008b. Poder popular y limites de democracia participativa en Venezuela: La experiencia de los Consejos Comunales. Paper delivered at the II Conferencia de la Sección Venezolana de la Latin American Studies Association (LASA), Caracas, May.

García-Guadilla, María Pilar, and Carlos Pérez. 2002. Democracy, Decentralization, and Clientelism: New Relationships and Old Practices. Latin American Perspectives 29 (5): 90-109.

Geertz, Clifford. 1973. The Interpretation of Cultures. New York: Basic Books, Inc.

- 2004. What Is a State If It Is Not a Sovereign? Reflections on Politics in Complicated Places. Current Anthropology 45 (5): 577-593.

Gledhill, John. 1994. Power and Its Disguises. Anthropological Perspectives on Politics. London: Pluto Press.

- 1995. Neoliberalism, Transnationalization and Rural Poverty: A Case Study of Michoacan, Mexico. Boulder: Westview Press.

- 2000. Getting New Bearings in the Labyrinth: The Transformation of the Mexican State and the Real Chiapas. Lecture manuscript, Department of Social Anthropology, University of Manchester.

- 2001. Corruption as the Mirror of the State in Latin America. In Between Morality and the Law: Corruption, Anthropology and Comparative Society, ed. I. Pardo. Aldershot: Ashgate Publishing.

- 2002. The Power Behind the Masks: Mexico's Political Class and Social Elites at the End of the Millenium. In Elite Cultures. Anthropological Perspectives, ed. C. Shore and S. Nugent. London and New York: Routledge.

. 2004. Neoliberalism. In A Companion to the Anthropology of Politics, ed. D. Nugent and J. Vincent. Malden, MA: Blackwell Publishing.

_. 2008. "The People's Oil": Nationalism, Globalization, and the Possibility of Another Country in Brazil, Mexico, and Venezuela. Focaal-European Journal of Anthropology 52: 57-74.

Gledhill, John, and Maria Gabriela Hita. 2009. New Actors, New Political Spaces, Same Divided City? Reflections on Poverty and the Politics of Urban Development in Salvador, Bahia. BWPI Working Paper 102, Brooks World Poverty Institute, University of Manchester, UK. 
Goffman, Erving. 1956. The Presentation of Self in Everyday Life. New York: Doubleday.

Golinger, Eva. 2005. El Código Chávez. Descifrando la intervención de los EE.UU en Venezuela. Caracas: Fondo Editorial Question.

- 2011. Color Revolution: Washington Funds Venezuela's "Made in the USA Oppositon". Globalresearch, August 11. http://www.globalresearch.ca/ color-revolutions-washington-funds-venezuela-s-made-in-the-usa-opposition/25984. Accessed February 20, 2017.

González, Rafael Gustavo. 2013. La palanca. Aporrea, June 20. http://www. aporrea.org/actualidad/al69067.html. Accessed February 20, 2017.

Gott, Richard. 2005. Hugo Chávez and the Bolivarian Revolution. London and New York: Verso.

Graeber, David. 2011. Consumption. Current Anthropology 52 (4): 489-511.

Grisanti, Luis Xavier. n.d. ¿¿Sembrar el petroleo o sembrar ciudadanos? Petroleo $Y V$. http://www.petroleoyv.com/website/uploads/grisanti_5.pdf. Accessed February $20,2017$.

Guerra, Natacha. 2009. La ideología del resentido. El Universal, February 13. http://www.eluniversal.com/opinion/090213/la-ideologia-del-resentido. Accessed February 20, 2017.

Guevara, Ernesto Che. 2003 [1965]. Socialism and Man in Cuba. In Che Guevara Reader. Writings on Politics and Revolution, ed. D. Deutchman. Melbourne and New York: Ocean Press.

Guijt, Irene, and Meera Kaul Shah. 1998. Waking up to Power, Conflict and Process. In The Myth of Community. Gender Issues in Participatory Development, ed. I. Guijt and M.K. Shah. London: ITDG Publishing.

Gupta, Akhil. 1995. Blurred Boundaries: The Discourse of Corruption, the Culture of Politics, and the Imagined State. In The Anthropology of the State. A Reader, ed. A. Sharma and A. Gupta. Oxford: Blackwell Publishing.

- 2001. Governing Populations: The Integrated Child Development Services Program in India. In States of Imagination. Ethnographic Explorations of the Postcolonial State, ed. T.B. Hansen and F. Stepputat. Durham and London: Duke University Press.

Gupta, Akhil, and James Ferguson. 1997. Culture, Power, Place: Explorations in Critical Anthropology. Durham and London: Duke University Press.

Haller, Dieter, and Chris Shore. 2005. Corruption. Anthropological Perspectives. London and Ann Arbor, MI: Pluto Press.

Hansen, Thomas Blom, and Finn Stepputat. 2001. Introduction: States of Imagination. In States of Imagination. Ethnographic Explorations of the Postcolonial State, ed. T.B. Hansen and F. Stepputat. Durham and London: Duke University Press.

Harrison, Faye. 1995. The Persistent Power of "Race" in the Cultural and Political Economy of Racism. Annual Review of Anthropology 24: 47-74.

Harvey, David. 2003. The New Imperialism. Oxford: Oxford University Press. 
2005. A Brief History of Neoliberalism. Oxford: Oxford University Press. Hawkins, Kirk. 2010. Venezuela's Chavismo and Populism in Comparative Perspective. Cambridge: Cambridge University Press.

Hawkins, Kirk A., and David R. Hansen. 2006. Dependent Civil Society: The Círculos Bolivarianos in Venezuela. Latin American Research Review 41 (1): 102-132.

Hawkins, Kirk, Guillermo Rosas, and Michel E. Johnson. 2011. The Misiones of the Chávez Government. In Venezuela's Bolivarian Democracy. Participation, Politics and Culture under Chávez, ed. D. Smilde and D. Hellinger. Durham and London: Duke University Press.

Hellinger, Daniel. 1984. Populism and Nationalism in Venezuela: New Perspectives on Acción Democrática. Latin American Perspectives 11 (4): 33-59.

- 1996. Introduction. Latin American Perspectives 23 (3): 3-9.

- 2000a. Review: Understanding Venezuela's Crisis: Dutch Disease, Money Doctors, and Magicians. Latin American Perspectives 27 (1): 105-119.

- 2000b. Nationalism, Oil Policy and the Party System in Venezuela. Paper delivered at the Conference for Latin American Studies Association, Hyatt Regency, Miami, March 16-18.

-2001. Tercermundismo and Chavismo. Revised version of paper delivered at Meeting of the Latin American Studies Association, Washington, DC, September 2-8.

. 2005. When "No" Means "Yes" to Revolution: Electoral Politics in Bolivarian Venezuela. Latin American Perspectives 32 (3): 8-32.

. 2016. Oil and the Chávez Legacy. Latin American Perspectives 44 (1): $54-77$.

Herrera Salas, Jesús María. 2005. Ethnicity and Revolution: The Political Economy of Racism in Venezuela. Latin American Perspectives 32 (2) (Issue 141): 72-91.

Hickey, Samuel, and Giles Mohan. 2004. Participation. From Tyranny to Transformation? London: Zed Books.

Hillman, Richard. 1994. Democracy for the Privileged. Crisis and Transition in Venezuela. Boulder and London: Lynne Rienner Publishers.

Hobbes, Thomas. 1996 [1651]. Leviathan. Oxford: Oxford University Press.

Hobsbawm, Eric, and Terence O. Ranger. 1992. The Invention of Tradition. Cambridge: Cambridge University Press.

Hoffman, Kelly, and Miguel Angel Centeno. 2003. The Lopsided Continent: Inequality in Latin America. Annual Review of Sociology 29: 363-390.

Howell, Signe. 1997. Introduction. In The Ethnography of Moralities, ed. S. Howell. London and New York: Routledge.

Humphreys, Macartan, Jeffrey D. Sachs, and Joseph E. Stiglitz. 2007. Escaping the Resource Curse. New York: Columbia University Press. 
Hyatt, Susan B. 2001. From Citizen to Volunteer: Neoliberal Governance and the Erasure of Poverty. In The New Poverty Studies. The Ethnography of Power, Politics and Impoverished People in the United States, ed. J. Goode and J. Makovsky. New York: New York University Press.

INE. n.d. Indicadores Sociales-Pobreza. Instituto Nacional de Estadistica. http://www.ine.gov.ve/index.php?option=com_content\&view=category\&id $=104 \&$ Itmid $=45 \#$. Accessed February 20, 2017.

Informe21. 2013. Venezuela: El consumismo versus socialismo del siglo XXI. http:// informe21.com/elecciones-presidenciales/venezuela-el-consumismo-versussocialismo-del-siglo-xxi. Accessed February 20, 2017.

Irazábal, Clara, and John Foley. 2010. Reflections on the Venezuelan Transition from a Capitalist Representative to a Socialist Participatory Democracy. What Are Planners to Do? Latin American Perspectives 37 (1): 97-122.

Jackson, Peter. 1999. Commodity Cultures: The Traffic in Things. Transactions of the Institute of British Geographers 24 (1): 95-108.

. 2004. Local Consumption Cultures in a Globalizing World. Transactions of the Institute of British Geographers 29 (2): 165-178.

Jansen, Robert. 2011. Populist Mobilization: A New Theoretical Approach to Populism. Sociological Theory 29 (75): 75-96.

Jensen, Steffen. 2001. The Battlefield and the Prize: ANC's Bid to Reform the South African State. In States of Imagination. Ethnograpic Explorations of the Postcolonial State, ed. T.B. Hansen and F. Stepputat. Durham and London: Duke University Press.

Joseph, Gilbert M., and Daniel Nugent. 1994. Everyday Forms of State Formation. Revolution and Negotiation of Rule in Modern Mexico. Durham and London: Duke University Press.

Karl, Terry Lynn. 1997. The Paradox of Plenty. Oil Booms and Petro-States. Berkeley: University of California Press.

- 1999. The Perils of the Petro-State: Reflections on the Paradox of Plenty. Journal of International Affairs 53 (1): 31-48.

Kenny, Robert Wade. 2010. Beyond the Elementary Forms of Moral Life: Reflexivity and Rationality in Durkheim's Moral Theory. Sociological Theory 28 (2): 215-244.

Knight, Alan. 1998. Populism and Neo-populism in Latin America, Especially Mexico. Journal of Latin American Studies 30 (2):223-248.

Krohn-Hansen, Christian, and Knut G. Nustad. 2005a. Introduction. In State Formation. Anthropological Perspectives, ed. C. Krohn-Hansen and K.G. Nustad. London and Ann Arbor, MI: Pluto Press.

- 2005b. State Formation. Anthropological Perspectives. London and Ann Arbor, MI: Pluto Press. 
Lambek, Michael. 2011. Catching the Local. Anthropological Theory 11 (2): 197-221.

Lander, Edgardo. 2005. Venezuelan Social Conflict in a Global Context. Latin American Perspectives 32 (2): 20-38.

Lander, Edgardo, and Luis A. Fierro. 1996. The Impact of Neoliberal Adjustment in Venezuela, 1989-1993. Latin American Perspectives 23 (3): 50-73.

La Nueva. 2010. Editorial: El auge de la viveza criolla. La Nueva, December 26. http://www.lanueva.com/Sociedad-/440601/el-auge-de-la-viveza-criolla. html. Accessed February 20, 2017.

Lazar, Sian. 2008. El Alto, Rebel City. Self and Citizenship in Andean Bolivia. Durham and London: Duke University Press.

Lefebvre, Henri. 1991. The Production of Space. Oxford: Wiley-Blackwell.

León, Luis Vicente, and David Smilde. 2009. Understanding Populism and Political Participation: The Case of Venezuela. Washington, DC: Woodrow Wilson International Center for Scholars.

Lewis, Oscar. 1966. La Vida: A Puerto Rican Family in the Culture of Poverty. San Juan and New York. New York: Random House.

Lieuwen, Edwin. 1961. Venezuela. Oxford: Oxford University Press.

Lindisfarne, Nancy. 2008. Starting from Below. Fieldwork, Gender and Imperialism Now. In Taking Sides. Ethics, Politics and Fieldwork in Anthropology, ed. H. Armbruster and A. Lærke. New York and Oxford: Berghahn Books.

Logan, Owen, and John-Andrew McNeish. 2012. Rethinking Responsibility and Governance in Resource Extraction. In Flammable Societies. Studies on the Socio-economics of Oil and Gas, ed. J.-A. McNeish and O. Logan. London: Pluto Press.

Long, Norman. 1999. The Multiple Optic of Interface Analysis (Working Title). UNESCO Background Paper on Interface Analysis, October. http://lanic. utexas.edu/project/etext/llilas/claspo/workingpapers/multipleoptic.pdf. Accessed February 20, 2017.

Lukes, Steven. 1982. Introduction. In The Rules of Sociological Method by Emile Durkheim, ed. S. Lukes. New York, London, Toronto, Sydney: The Free Press. Lupu, Noam. 2010. Who Votes for "Chavismo"? Class Voting in Hugo Chávez's Venezuela. Latin American Research Review 45 (1): 7-32.

Machado M., Jesús E. 2008. Estudio de los consejos comunales en Venezuela. Caracas: Fundación Centro Gumilla.

- 2009a. Participación social y consejos comunales en Venezuela. Revista Venezolana de Economia y Ciencias Sociales 15 (1): 173-185.

- 2009b. Estudio cuantitativo de opinión sobre los consejos comunales. Caracas: Fundación Centro Gumilla.

MacLennan, Carol. 2005. Corruption in Corporate America: Enron-Before and After. In Corruption. Anthropological Perspectives, ed. C. Shore and D. Haller. London and Ann Arbor, MI: Pluto Press. 
Margheritis, Ana, and Anthony W. Pereira. 2007. The Neoliberal Turn in Latin America: The Cycle of Ideas and the Search for an Alternative. Latin American Perspectives 34 (3): 25-48.

Marques, Eduardo. 2012. State Institutions, Power, and Social Networks in Brazilian Urban Politics. Latin American Research Review 47 (2): 27-50.

Marx, Karl. 1992 [1867]. Capital: A Critique of Political Economy-Volume 1. New York: Penguin Classics.

Maurer, Bill. 2006. The Anthropology of Money. Annual Review of Anthropology 36: $15-36$.

Mauss, Marcel. 1954. The Gift: Forms and Functions of Exchange in Archaic Societies. New York: W.W. Norton.

Maya, Margarita López. 201la. Hacia el socialismo del siglo XXI: Los consejos comunales, sus cambios conceptuales y las percepciones de los participantes en Caracas. In Ciudadania y Legitimidad Democrática en América Latina, ed. I. Cheresky. Buenos Aires: Prometeo.

- 2011 b. Venezuela entre incertidumbres y sorpresas. Nueva Sociedad, No. 235 (September-October).

Maya, Margarita López, Luis Lander, and Dick Parker. 2005. Popular Protest in Venezuela: Novelties and Continuities. Latin American Perspectives 32 (2): 92-108.

Maya, Margarita López, David Smilde, and Keta Stephany. 2002 [1999]. Protesta y culturaen Venezuela. Los Marcos de Acción Colectiva en 1999. Caracas: FACESUCV, CENDES, FONACIT.

McCoy, Jennifer L., and David J. Myers. 2004. The Unraveling of Representative Democracy in Venezuela. Baltimore and London: The Johns Hopkins University Press.

McGregor, Sue. 2002. Consumer Citizenship: A Pathway to Sustainable Development? Keynote speech delivered at the International Conference on Developing Consumer Citizenship, Hamar, Norway, April n.d. http://www.consultmcgregor. com/documents/keynotes/norway_keynote.pdf. Accessed February 20, 2017.

McNeish, John-Andrew. 2001. Pueblo Chico, Infierno Grande. Globalisation and the Politics of Participation in Highland Bolivia. PhD dissertation, Department of Anthropology, University of London.

McNeish, John-Andrew, and Owen Logan. 2012. Conclusion: All Other Things Do Not Remain Equal. In Flammable Societies. Studies on the Socio-economics of Oil and Gas, ed. J.-A. McNeish and O. Logan. London: Pluto Press.

Michels, Robert. 1962. Political Parties. A Sociological Study of the Oligarchical Tendencies of Modern Democracy. New York and London: The Free Press/ Collier-Macmillan Ltd.

Michelutti, Lucia. 2016. "We Are All Chávez": Charisma as an Embodied Experience. Latin American Perspectives 44 (1): 232-250.

Miles, Steven. 1998. Consumerism as a Way of Life. London: Sage. 
Miller, Daniel. 1987. Material Culture and Mass Consumption. Oxford: Basil Blackwell.

- 1995. Consumption and Commodities. Annual Review of Anthropology 24: 141-161.

Mitchell, Timothy. 2006 [1999]. Society, Economy and the State Effect. In The Anthropology of the State. A Reader, ed. A. Sharma and A. Gupta. Oxford: Blackwell Publishing.

- 2011. Carbon Democracy: Political Power in the Age of Oil. London: Verso.

Mommer, Bernhard. 1996. Integrating the Oil: A Structural Analysis of Petroleum in the Venezuelan Economy. Latin American Perspectives 23 (3): 132-158.

- 2004. Subversive Oil. In Venezuelan Politics in the Chávez Era: Class, Polarization, and Conflict, ed. S. Ellner and D. Hellinger. Boulder and London: Lynne Rienner Publishers.

Moreno, Marco Aponte. 2008. Metaphors in Hugo Chávez Political Discourse: Conceptualizing Nation, Revolution, and Opposition. PhD dissertation, Graduate Faculty in Hispanic and Luso-Brazilian, City University of New York.

Motta, Sara. 2013. "We Are the Ones We Have Been Waiting For": The Feminization of Resistance in Venezuela. Latin American Perspectives 40 (4): 35-54.

Mullings, Leith. 2005. Interrogating Racism: Toward an Antiracist Anthropology. Annual Review of Anthropology 34: 667-693.

Mullins, Paul R. 2011. The Archaeology of Consumer Culture. Gainesville: University Press of Florida.

Musica.com. n.d.a. Letra "Alberto Lovera, hermano". http://www.musica.com/ letras.asp?letra=1389248. Accessed February 20, 2017.

- n.d.b. Letra "Sangueo para el Regreso". http://www.musica.com/letras. asp?letra=1093256. Accessed February 20, 2017.

Nelson, Brian. 2009. The Silence and the Scorpion: The Coup against Chavez and the Making of Modern Venezuela. New York: Nation Books.

Neuman, Iver. 2005. 'A Speech That the Entire Ministry May Stand For': On Generating State Voice. In State Formation. Anthropological Perspectives, ed. C. Krohn-Hansen and K.G. Nustad. London and Ann Arbor, MI: Pluto Press.

Nichols, Elizabeth Gackstetter, and Kimberley J. Morse. 2010. Venezuela. Santa Barbara, California, Denver, Colorado and Oxford, England: ABC-CLIO.

Notiactual. 2011. Todos los centros Sambil de Venezuela celebrarán bodas colectivas el próximo 14 de febrero. Notiactual, January 13. http://www.notiactual.com/ todos-los-centros-sambil-de-venezuela-celebraran-bodas-colectivas-el-proximo14-de-febrero/. Accessed February 20, 2017. 
Notimex. 2011. Llama Hugo Chávez a superar los viejos vicios de capitalismo. www.excelsior.com, July 12. http://www.excelsior.com.mx/node/752163. Accessed February 20, 2017.

Nugent, Daniel. 1993. Spent Cartridges of Revolution. An Anthropological History of Namiquipa, Chibuahua. Chicago and London: The University of Chicago Press.

Nugent, David. 1996. From Devil Pacts to Drug Deals: Commerce, Unnatural Accumulation, and Moral Community in "Modern" Peru. American Ethnologist 23 (2): 258-290.

-1997. Modernity at the Edge of Empire. State, Individual and Nation in the Northern Peruvian Andes, 1885-1935. Stanford, CA: Stanford University Press.

Nugent, Daniel. 1998. Rural Revolt in Mexico, U.S. Intervention and the Domain of Subaltern Politics. Durham and London: Duke University Press.

Nuijten, Monique. 2003. Power, Community, and the State. The Political Anthropology of Organization in Mexico. London and Sterling, VA: Pluto Press.

O'Connor, Alice. 2001. Poverty Knowledge: Social Science, Social Policy, and the Poor in Twentieth-Century U.S. History. Princeton, NJ: Princeton University Press.

Orhangazi, Özgür. 2011. Contours of Alternative Policy Making in Venezuela. Amherst: University of Massachusets.

Pardo, Italo. 2004a. Between Morality and the Law. Corruption, Anthropology and Comparative Society. Aldershot: Ashgate Publishing.

- 2004b. Introduction. Corruption, Morality and the Law. In Between Morality and the Law. Corruption, Anthropology and Comparative Society, ed. I. Pardo. Aldershot: Ashgate Publishing.

Parry, Jonathan, and Maurice Bloch. 1989. Money and the Morality of Exchange. Cambridge: Cambridge University Press.

Penfold-Becerra, Michael. 2007. Clientelism and Social Funds: Evidence from Chávez' Misiones. Latin American Politics and Society 49 (4): 63-84.

Pérez Alfonzo, Juan Pablo. 2011 [1976]. Hundiéndonos en el excremento del diablo. Caracas: Banco Central de Venezuela.

Pierce, Steven. 2006. Looking Like a State: Colonialism and the Discourse of Corruption in Northern Nigeria. Comparative Studies in Society and History 48 (4): 887-914.

Pigg, Stacy Lee. 1992. Inventing Social Categories through Place: Social Representation and Development in Nepal. Comparative Studies in Society and History 34 (3): 491-513.

- 1996. The Credible and the Credulous: The Question of "Villagers' Believes" in Nepal. Cultural Anthropology 11 (2): 160-201.

Poljak, Ernesto Villegas. 2012. Abril, golpe adentro. Caracas: FUNDARTE. 
Ponce, Maria Gabriela, and Lissette Gonzáles. 2015. Pobreza and gasto social en la Venezuela de a Revolución Bolivariana. Caracas: CEDICE.

Ponniah, Thomas, and Jonathan Eastwood. 2011. The Revolution in Venezuela. Social and Political Change under Chavez. Cambridge, MA: David Rockefeller Center for Latin American Studies, Harvard University.

Portes, Alejandro, and Kelly Hoffman. 2003. Latin American Class Structures: Their Composition and Change during the Neoliberal Era. Latin American Research Review 38 (1): 41-82.

Prato, Giuliana. 2004. 'The Devil Is Not as Wicked as People Believe, Neither Is the Albanian': Corruption between Moral Discourse and National Identity. In Between Morality and the Law: Corruption, Anthropology and Comparative Society, ed. I. Prato. Aldershot: Ashgate Publishing.

Predrazzini, Yves, and Magalys Sanches. 2001. Malandros, bandas y niños de la calle. Caracas y Valencia: Vadell Hermanos Editores.

Rakowski, Cathy A., and Gioconda Espina. 2011. Advancing Women's Rights from Inside and Outside the Bolivarian Revolution, 1998-2010. In The Revolution in Venezuela. Social and Political Change under Chávez, ed. T. Ponniah and J. Eastwood. Cambridge, MA: David Rockefeller Center for Latin American Studies, Harvard University.

Ramazanoglu, Caroline, and Janet Holland. 2002. Feminist Methodology: Challenges and Choices. London: Sage Publications.

Rangel, Eleazar Díaz. 2006. La corrupción en Venezuela. Aporrea, August 6. http://www.aporrea.org/actualidad/a24200.html. Accessed February 20, 2017.

Républica Bolivariana de Venezuela. 2007. Proyecto Nacional Simón Bolívar 2007-2013. http://www.psuv.org.ve/wp-content/uploads/2011/03/ProyectoNacionalSim\%C3\%B3n-Bol\%C3\%ADvar.pdf. Accessed February 20, 2017.

Rigi, Jakob. 2004. Corruption in Post-Soviet Kazakhstan. In Between Morality and the Law: Corruption, Anthropology and Comparative Society, ed. I. Pardo. Aldershot: Ashgate Publishing.

Rivero Santos, Angelo. 1995. Neighborhood Organizations in Venezuela: "Los Vecinos" Voice Their Dissent. Yearbook: Conference of Latin American Geographers 21: 1-12.

Roberts, Kenneth. 2006. Populism, Political Conflict, and Grass-Roots Organization in Latin America. Comparative Politics 38 (2): 127-148.

Robertson, A.F. 2006. Misunderstanding Corruption. Anthropology Today 22 (2): 8-11.

Rodríguez, Fransisco. 2007. Sharing the Oil Wealth? Appraising the Effects of Venezuela's Social Programs. LASA Forum 38 (1): 22-25.

Rogers, Douglas. 2015. Oil and Anthropology. Annual Review of Anthropology 44: 365-380.

Ross, Michael. 2004. What Do We Know about Natural Resources and Civil War? Journal Of Peace Research 41 (3): 337-356. 
Rosser, Andrew. 2006a. Escaping the Resource Curse. New Political Economy 11 (4): 557-570.

- 2006b. The Political Economy of the Resource Curse: A Literature Survey. Working Paper 268, Institute of Development Studies, University of Sussex, Brighton.

Rousseau, Jean Jacques. 2010 [1762]. The Social Contract or Principles of Political Right. Trans. G.D.H. Cole. San Antonio, TX: The Constitution Society.

Sachs, Jeffrey D., and Andrew Warner. 1995a. Natural Resource Abundance and Economic Growth. Working Paper 5398, National Bureau of Economic Research and Harvard University, Cambridge, MA.

. 2001. The Curse of Natural Resources. European Economic Review 45 (4-6): 827-838.

Sxtre, Simen. 2009. Petromania. Oslo: J.M. Stenersens Forlag AS.

Said, Edward. 1978. Orientalism. New York: Vintage Books.

Saignes, Miguel Acosta. 2009. Bolivar. Acción y Utopia del Hombre de las Dificultades. Caracas: Ministerio del Poder Popular para la Cultura.

Salas, Jesús María Herrera. 2005a. Ethnicity and Revolution: The Political Economy of Racism in Venezuela. Latin American Perspectives 32 (2): 72-91.

Salas, Miguel Tinker. 2005b. Staying the Course: United States Oil Companies in Venezuela, 1945-1958. Latin American Perspectives 32 (2): 147-170.

- 2009. The Enduring Legacy. Oil, Culture, and Society in Venezuela. Durham and London: Duke University Press.

- 2015. Venezuela. What Everyone Needs to Know. New York: Oxford University Press.

Sánchez, Irey Gómez. 2006. El papel de las Misiones Sociales en la construcción de identidades políticas en Venezuela. Revista Venezolana de Economía y Ciencias Sociales 13 (1): 13-34.

Sandel, Michael. 1998. What Money Can't Buy: The Moral Limits of the Market. Speech delivered at the Tanner Lectures on Human Values, Brasenose College, Oxford, May 11-12.

Sanderson, Stephen. 1988. The Neo-Weberian Revolution: A Theoretical Balance Sheet. Sociological Forum 3 (2): 207-214.

Sapiezynska, Ewa. 2016. The Media and Power in Postliberal Venezuela: The Legacy of Hugo Chávez for the Debate on Freedom of Expression. Latin American Perspectives 44 (1): 199-214.

Sawyer, Suzana. 2004. Crude Chronicles: Indigenous Politics, Multinational Oil, and Neoliberalism in Ecuador. Durham: Duke University Press.

Schiller, Naomi. 2011. Catia Sees You: Community Television, Clientelism, and the State in the Chávez Era. In Venezuela's Bolivarian Democracy. Participation, Politics and Culture under Chávez, ed. D. Smilde and D. Hellinger. Durham and London: Duke University Press.

Schneider, Mark. 1987. Culture-as-Text in the Work of Clifford Geertz. Theory and Society 16 (6): 809-839. 
Scott, James. 1985. Weapons of the Weak. Everyday Forms of Peasant Resistance. New Haven and London: Yale University Press.

- 1999. Seeing Like a State: How Certain Schemes to Improve the Human Condition Have Failed. New Haven and London: Yale University Press.

Sharma, Aradhana, and Akhil Gupta. 2006a. The Anthropology of the State: A Reader. Oxford: Blackwell Publishing.

- 2006b. Introduction: Rethinking Theories of the State in an Age of Globalization. In The Anthropology of the State. A Reader, ed. A. Sharma and A. Gupta. Oxford: Blackwell Publishing.

Sheriff, Robin. 2001. Dreaming Equality. Color, Race, and Racism in Urban Brazil. New Brunswick, New Jersey, and London: Rutgers University Press.

Shore, Cris, and Dieter Haller. 2005. Introduction. Sharp Practice: Anthropology and the Study of Corruption. In Corruption. Anthropological Perspectives, ed. C. Shore and D. Haller. London and Ann Arbor, MI: Pluto Press.

Shore, Cris, and Stephen Nugent. 2002. Elite Cultures. Anthropological Perspectives. London and New York: Routledge.

Shore, Cris, and Susan Wright. 1997. Anthropology of Policy. Critical Perspectives on Governance and Power. New York: Routledge.

Silva, Emilio. 2005. Qué es ser de la Socieded Sambil? Aporrea, June 2. http:// www.aporrea.org/actualidad/a13751.html. Accessed February 20, 2017.

Slater, Don. 1997. Consumer Culture and Modernity. Cambridge: Polity Press.

Smilde, David, and Daniel Hellinger. 2011. Venezuela's Bolivarian Democracy. Participation, Politics, and Culture under Chávez. Durham and London: Duke University Press.

Sørhøy, Marit Smith, and Wenche Heir. n.d. Energi og energibehov. Digitale læremidler for videregående opplæring. NDLA. http://ndla.no/nb/node/61375. Accessed February 20, 2017.

Starn, Orin. 1999. Nightwatch. The Politics of Protest in the Andes. Durham and London: Duke University Press.

Strønen, Iselin Åsedotter. 2006. "For Us This Is Utopia Coming True." Venezuela's Bolivarian Revolution and Popular Movements in a Caracas Barrio. MA thesis, Department for Social Anthropology, University of Bergen.

- 2012. Development from Below and Oil Money from Above: Popular Organization in Contemporary Venezuela. In Flammable Society. Studies on the Socio-economics of Oil and Gas, ed. J.-A. McNeish and O. Logan. London: Pluto Press.

- 2013. En feministisk revolusjon? Kvinner, kvinnekamp og aktivisme i Chávez' Venezuela. Norsk Antropologisk Tidsskrift 1 (24): 39-51.

- 2016. "A Civil-Military Alliance": The Venezuelan Armed Forces before and during the Chavez-Era. CMI Working Paper Series 2016:4, Chr. Michelsen Institute, Bergen.

Sunstein, Cass. 1998. More Is Less. Review Article of Seeing Like a State: How Certain Schemes to Improve the Human Condition Have Failed by James Scott. The New Republic 37. 
Taussig, Michael. 1977. The Genesis of Capitalism amongst a South American Peasantry: Devil's Labor and the Baptism of Money. Comparative Studies in Society and History 19 (2): 130-155.

- 1980. The Devil and Commodity Fetishism in Latin America. Chapel Hill: The University of North Carolina Press.

- 1991. Shamanism, Colonialism, and the Wild Man: A Study in Terror and Healing. Chicago: University of Chicago Press.

Thomassen, Bjørn. 2012. Notes towards an Anthropology of Political Revolutions. Comparative Studies in Society and History 54 (3): 679-706.

Tilly, Charles, and Sidney Tarrow. 2007. Contentious Politics. Boulder and London: Paradigm Publishers.

Törnquist, Olle, Neil Webster, and Kristian Stokke. 2009. Rethinking Popular Participation. New York: Palgrave Macmillan.

Torsello, Davide. 2011. The Ethnography of Corruption: Research Themes in Political Anthropology. QoG Working Papers Series 2011:2, University of Gothenburg, Sweden.

Trinkunas, Harold. 2002. The Crisis in Venezuelan Civil-Military Relations: From Punto Fijo to the Fifth Republic. Latin American Research Review 37 (1): $41-76$.

UNDP. 2010. Acting on the Future. Breaking the Intergenerational Transmission of Inequality. The Regional Human Development Report for Latin America and the Caribbean 2010, UNDP, United Nations. http://hdr.undp.org/en/content/acting-future. Accessed February 20, 2017.

UN-Habitat. 2012. The State of Cities in Latin America and the Caribbean 2012. Towards a New Urban Transition. http://www.citiesalliance.org/sites/citiesalliance.org/files/SOLAC-ProjectOutput.pdf. Accessed February 20, 2017.

Universidad de los Andes, Venezuela. n.d. Conceptos $y$ definiciones de población y vivienda. http://iies.faces.ula.ve/censo90/Conceptos_definiciones_de_poblaci\%C3\%B3n_vivienda.html. Accessed February 20, 2017.

Valencia, Cristobal. 2015. We Are the State! Barrio Activism in Venezuela's Bolivarian Revolution. Tucson: The University of Arizona Press.

Van Roy, Edward. 1970. On the Theory of Corruption. Economic Development and Cultural Change 19 (1): 86-110.

Velasco, Alejandro. 2015. Urban Popular Politics and the Making of Modern Venezuela. Oakland: University of California Press.

VTV. 2013a. Barrio Adentro celebra 10 años inaugurando el Centro de Diagnóstico Integral $\mathrm{N}^{\circ}$ 561. Venezolana de Television, April 16. http://www.vtv.gob.ve/ articulos/2013/04/16/venezuela-cuenta-con-561-cdi-480.html. Accessed December 20, 2013.

- 2013b. Casi 500 comunas se han inscrito en el Registro Nacional en Venezuela. Venezolana de Television, November 25. http://www.vtv.gob.ve/ 
articulos $/ 2013 / 11 / 25 /$ casi-500-comunas-se-han-inscrito-en-registronacional-en-venezuela-7284.html. Accessed March 7, 2014.

Wacquant, Loïc. 2005. Castigar a los Parias Urbanos. Oficios Terrestres (XI):10-15. - 2012. Three Steps to a Historical Anthropology of Actual Existing Neoliberalism. Social Anthropology/Anthropologie Sociale 20 (1): 66-79.

Walsh, Andrew. 2003. "Hot Money" and Daring Consumption in a Northern Malagasy Sapphire-Mining Town. American Ethnologist 30 (2): 290-305.

Walsh, Catherine. 2008. Interculturalidad, Plurinacionalidad y Decolonialidad: Las Insurgencias Político-Epistémicas de Refundar el Estado. Tabula Rasa 9: $131-152$.

Watts, Michael. 1999. Petro-Violence: Some Thoughts on Community, Extraction, and Political Ecology. Working Paper 99-1, Institute of International Studies, University of California, Berkeley.

- 2004. Anatomies of Community: Some Thoughts on Geography, Resources and Empire. Transactions of the Institute of British Geographers 29 (2): 195-216.

Weisbrot, Mark. 2014. US Support for Regime Change in Venezuela Is a Mistake. The Guardian, February 2014. http://www.theguardian.com/commentisfree $/ 2014 / \mathrm{feb} / 18 /$ venezuela-protests-us-support-regime-change-mistake. Accessed February 20, 2017.

Weisbrot, Mark, and Jake Johnston. 2012. Venezuela's Economic Recovery: Is It Sustainable? Washington, DC: Center for Economic and Policy Research.

Weisbrot, Mark, and Luis Sandoval. 2007. The Venezuelan Economy in the Chávez Years. Washington, DC: Center for Economic and Policy Research.

Weyland, Kurt. 1999. Neoliberal Populism in Latin America and Eastern Europe. Comparative Politics 31 (4): 379-401.

- 2001. Clarifying a Contested Concept: Populism in the Study of Latin American Politics. Comparative Politics 34 (1): 1-22.

- 2004. Neoliberalism and Democracy in Latin America: A Mixed Record. Latin American Politics and Society 46 (1): 135-157.

Wiarda, Howard. 1971. Law and Political Development in Latin America: Toward a Framework for Analysis. The American Journal of Comparative Law 19 (3): 434-463.

WikiLeaks. 2015. The WikiLeaks Files. London and New York: Verso.

Willson, Margaret. 2007. Dance Lest We All Fall Down: Breaking Cycles of Poverty in Brazil and Beyond. Seattle: University of Washington Press.

Wilpert, Gregory. 2003. Venezuela's New Constitution. Venezuelaanalysis, August 27. http://venezuelanalysis.com/analysis/70. Accessed February 20, 2017.

. 2007. Making Sense of Venezuela's Constitutional Reform. Venezuelaanalysis, December 1. http://venezuelanalysis.com/analysis/2943. Accessed February 20, 2017. 
2011. Venezuela's Experiment in Participatory Democracy. In The Revolution in Venezuela. Social and Political Change under Chávez, ed. T. Ponniah and J. Eastwood. Cambridge, MA: David Rockefeller Center for Latin American Studies, Harvard University.

Wolf, Eric. 1990. Distinguished Lecture: Facing Power-Old Insights, New Questions. American Anthropologist 92 (3): 586-596.

Wolf, Eric, and Edward Hansen. 1972. The Human Condition in Latin America. New York, London and Toronto: Oxford University Press.

World Observer Online. 2013. 'It Hurts So Much I Can't Sit Down': The Dangerous Practice of Butt Implants That Is Ruining Women's Lives across Venezuela. World Observer Online, November 16. http://worldobserveronline. com/2013/11/16/hurts-much-cant-sit-dangerous-practice-butt-implantsruining-womens-lives-across-venezuela/. Accessed February 20, 2017.

Wright, Winthrop. 1990. Café con Leche. Race, Class and National Image in Venezuela. Austin: University of Texas Press.

Ystanes, Margit. 2011. Precarious Trust. Problems of Managing Self and Sociality in Guatemala. PhD dissertation, Department of Anthropology, University of Bergen.

Zibechi, Raúl. 2010. Dispersing Power: Social Movements as Anti-State Forces. Oakland, Edinburgh, Baltimore: AK Press.

Ziccardi, Alicia. 2008. Pobreza y exclusión social en las ciudades del siglo XXI. In Procesos de Urbanización de la Pobreza y Nuevas Formas de Exclusión Social, ed. A. Ziccardi. Bogotá, D.C., Colombia and Buenos Aires, Argentina: Siglo del Hombre Editores and CLACSO-CROP.

Zinn, Dorothy Louise. 2005. Afterword-Anthropology and Corruption: The State of the Art. In Corruption. Anthropological Perspectives, ed. D. Haller and C. Shore. London and Ann Arbor, MI: Pluto Press.

\section{Audiovisuals}

1980. The Gods Must Be Crazy. Dir. Jamie Uys. South Africa: CAT Films/Mimosa Films.

2003. The Revolution Will Not Be Televised. Dir. Kim Bartley and Donnacha O'Briain. Galway, Ireland: Power Pictures.

2004. Puente Llaguno: Claves de una Masacre [Llaguno Bridge: Keys to a Massacre]. Dir. Ángel Palacios. Caracas: Producciones Panafilms.

2007. The People and the President. A Portrait of the Bolivarian Revolution. Dir. Iselin Strønen and Hildegunn Wærness. Bergen, Norway: Geriljastil Productions. 


\section{INDEX $^{1}$}

NUMBERS \& SYMBOLS

23 de Enero, the parish of, 16-18, $21-3,60,63-5,68,69,71,77$, $78,89,107,111,112,116,119$, 124-9, 131, 133, 134, 139, 140, $145,146,148,150,151,157$, $178-80,185,186,189,194$, 196, 205, 206, 210, 214, 215, $218,223,237,240,241,256$, $260,267,271,279,300$

A

Acción Democrática, 31, 32, 34-7, $41,42,49,52 \mathrm{nl}, 57,61,62$, 64-6, 80, 81n4, 93, 94, 170-2, 263, 265, 267, 289, 290, 303, 314

adecos, 68, 171, 172, 263, 267, 289, $295,296,305,305 \mathrm{nl}$

anthropology of corruption, 283-6

of oil, 6-10, 274, 322-6

of the state, 10-12, 161-6
B

barrios

and community politics, 133, 136, 160,179

and political dynamics, 52, 112

and poverty, $20,50,73-5,228-9$, $256-9,314$

and social space, $13-22,122-3$

and spatial dynamics, 122-3, 148-51

Betancourt, Rómulo, 31-6, 62, 317, 318

Bolivarian Circles, 127, 157

Bolivarian ideology, 105, 219

Bolivarian space, 114, 160, 172, $186-7,216,219,312,320,321$

Bolívar, Simón, 31, 70, 101-4, 106, $120,125,145,178,193,215$, 224, 244, 291, 292, 299

Bureaucracia, la, 11

bureaucracy, 36, 37, 113, 159, 162-4, 166-8, 172, 177, 178, 181, 185, $186,190,193,212,284,285$, $289,320,322$

${ }^{1}$ Note: Page number followed by 'n' refers to notes

(C) The Author(s) 2017

I.Å. Strønen, Grassroots Politics and Oil Culture in Venezuela, DOI 10.1007/978-3-319-59507-8 
C

Caracazo, el, 38, 39, 73, 74, 76, 78, $94,189,236,314$

Chávez, Hugo and 1992 coup attempt, 74, 94, 286,315

and 2002 coup, $73,100,115,126$, $127,157,159$

and caudillismo, 105

and oil policy, 48, 50

and populism, 58-60, 100, 106, 275

and racism, 92-5

and social policy (see social missions and the misiones)

Chavistas, 60, 97-9, 102, 106, 127, $170,171,189,216,245$

civil society, 96-7, 244, 284 and the opposition, 96, 245 class, 290

and class conflict, 41-2, 48-50, 61-6, 91-100, 242-7

and class identity, 30, 233, 304

and middle class, 42,245

and race, 85-107, 262

and spatial segregation, 89-91

clientelism, 34, 42, 62, 64, 168, 203, $237,266,293,295$

colectivos, 70, 125-8, 133, 134, 136, $138-47,149,150,176,179$, $180,215,240$

collective memories, 80

Colombia, 58, 102, 193, 291

Comités de Tierra Urbana, 117

Communal Councils, 120-2, 141 and Law for Communal Councils, $118,120,152,152 \mathrm{n} 3,185$, 203, 209, 216, 217, 299

communists, $32,35,47,68,69,310$

community, 111-14, 116-18, 120-38, 140-4, 146-52, 152n1, 152n3, $153 \mathrm{n} 6$

and local politics, 133 and spatial politics, 125, 150

and theory of, $152 \mathrm{nl}$

conspicuous consumption, 231, $233-7,239,247$

Constitution of the Bolivarian

Republic of Venezuela, 142,

$153 n 6$

consumption, 315

and capitalism, 230, 232, 321

and class, 243

and identity, 234, 236, 237, 239, 245,247

and influence from the United

States, 231, 234

and modernity, 234-6, 239, 247, 326

and neoliberalism, 247, 293

and oil, 230, 247, 259, 263, 274, 321

controlaría social, 131, 136, 152

Coordinadora Simón Bolívar, 70, 215

COPEI, 32, 36, 37, 41, 42, 62, 94,

171,265

copeyanos, 68, 171, 265, 296, 305,

$305 \mathrm{nl}$

Coronil, Fernando, 76, 77, 79, 94,

$162,225,230,232,233,263$, 287, 288, 293, 294, 316, 317,

$319,322,323,325,326$

corruption, 284

and anthropology of, 283-6

and class, 233, 289-90, 295, 302, 314

and colonialism, 284

and community politics, 276,282 , 283, 296, 298

Coup d' etat in 2002, 96, 127, 311

creoles, 244

D

drugs, $65,70,125,126,128,140$, 229 
E

economic inequality, 227, 234, 256, 302

elections, 32, 33, 36, 41, 42, 74, 99,

$100,111,118,121,153 \mathrm{n} 9,157$,

166, 211, 219, 219nl, 263-7,

$272,273,280,281,297,328$

El Universal, 86, 97

Erika Farías, 174, 175

Escualidos, 99

F

Fedecámeras, 49

Fondemi, 201, 210-13, 219, 219n3

Frente Fransisco de Miranda, 157, $158,170,174,189,254,303$

Fundacomunal, 112, 121, 133, 141,

$158,170,176,185-92,194$, $195,205,210,213,219,219 \mathrm{nl}$, 219n2, 262, 268, 280, 281, 296, 297, 300, 301

G

Gómez, Juan Vicente, 31, 32, 43, 93, 238

government

of Carlos Andrés Pérez, 38, 57, 73

of Juan Vicente Gómez, 93

of Luis Herrera Campins, 37

of Rafael Caldeira, 39, 40, 62, 63, 73

of Raul Leoni, 31, 36

of Romulo Betancourt, 31-3, 35, 61

governmentality, 161, 177

Gran Misión Vivenda de Venezuela, 254,270

grassroots movements, 5, 112-13, $115,118,120,125,160,162$, 167, 180, 267. See also popular movements and popular power
H

health care, $117,129,138$

hegemony, 94, 95, 162, 163, 166, $173,182,214,314,323$

Herrera Campins, Luis, 34, 37

hierarchy, 160, 214-17

housing projects, 185, 191, 197-9, $202,223,254,257,280,281$, 297,300

I

identity, 236

individualism, 10, 12, 219, 224, 230, $236,293,304$

informal labor, 39

Instituciones, las, 11

institutions, the $11,128,148,153$, $157,164,166-75,177-9,181$, 186-8, 190, 192-3, 197-8, 202, 205, 209-13

International Monetary Fund (IMF), $38,40,74,317$

and el Caracazo, 38, 74

and the government of Carlos

Andrés Pérez, 38, 57, 73, 234, 287

Istúriz, Aristóbulo, 189

J

Juntas de Vecinos, 267

L

liberal democracy, 3, 12, 60, 228, 323

Libertador Municipality, 131, 145, $149,178,214,268,271$

M

Maduro, Nicholas, 2, 100, 217

Magical State, the , 7, 79, 162, 263, 319 
malandros, 72

media, 4, 21, 33, 47, 49, 58, 91, 92, $94,96,119,126,170,171,233$, $241-3,256,314$

memory, collective, $4,6,7,79,80$, 162, 263, 319

migration, 29, 35, 45

Miraflores Palace, 49, 58, 85, 130, $142,147,153 \mathrm{n} 10$

Misión Barrio Adentro, 16, 52, 115-17, 128-31, 133, 134, 136, 148,150

Misión Madres de Barrio, 256, 268

Misión Mercal, 117

Misión Milagro, 257

Misión Ribas, 255, 257, 268

Misión Vuelvan Caracas, 116

modernity, 7, 8, 36, 46-7, 233, 236,

238-9, 246-7, 325-6

and class identities, 233, 304

and consumption, 23, 233-6, 239, $247,321,326$

and development, 7, 23, 36, 232-4, 304,324

and oil, 6-8, 46, 47, 113, 233, 247, 316,326

moral economy, 3, 225, 226, 247, 284 moralities, 219, 223-48, 248nl-7, 283, 284, 293, 296-8, 300-2, 304,321

Movimiento Quinta Republica

(MVR), 40

Municipio Libertador, 85, 189

Murales, 85

in 23 de Enero, 125

N

neighborhood associations, 65, 123

neoliberalism, 37-41, 226-9

and poverty, 226, 229

reforms, 227

social effects, 23, 226-7, 247, 274, 293,305
O

oil, 259

and culture, 45-7, 79, 230, 232-5, 262-3, 272-5, 288

and development, $7,22,45,46$, 288,304

and foreign oil companies, 2, 29, 46

and industry, 2, 30, 31, 35, 40, $42-8,94$

and modernity, 8, 46, 304

and oil camps, 46

and reforms, 6

and social programs, 36, 272

and state control over, 30, 49

and strike in $2002 / 2003,48,115$, 123,170

OPEC, 36, 44, 48, 317

$\mathbf{P}$

Pact of Puntofijo, 33, 35, 41, 61

Palanca, la, 167, 266

pardos, 93

participatory democracy, 114, 203

patronage, 64, 164, 168, 203

Pérez, Carlos Andrés, 36, 57, 58, 73, $74,78,79,265,286$

Pérez Jiménez, Marcos, 32, 33, 35, $61,67,126$

Petróleos de Venezuela (PDVSA), 19, $44,48-50,52,115,233,259$, 260,310

Piedrita, La, 125, 126, 133, 147, 180

police, 14, 63, 65, 67-73, 76, 86, 87, 126,135

violence, 72,125

popular democracy, 203

popular movement, 4-5, 60-6, 115.

See also grassroots movements and community politics, 23

and the state, $2-5,115-17,133-8$, $151,160-1,177-81,186-7$ 
popular power, 165, 170, 173, 174, $178,180,182,320$. See also grassroots movements and community politics, 11 and the state, 2-5, 113-14, 120-1, $133-8,151,177-81,186-7$, 198-203, 205-17

populism, 59, 60, 80, 80n2, 80n3 poverty, 9, 50, 64, 89-91, 95, 98, 99, $226,229,236,256-9,275-6$, 314,325

memories of, 73-6

and neoliberalism, 38, 73-6, 226-9 privatization, 37-40, 48, 90, 91, 129, 275,288

Promotores integrales, 23, 182, 187 , 188

Propatria, 17, 18, 73, 101, 114, 246, 257,264

Puntofijismo, 11, 35, 40, 42, 319

R

race

and class, 85-107, 262

and colonialism, 92-4

and racial prejudices, 92, 98

racism

and colonialism, 92-4

and political polarization, 94-9

radical democracy, 12

Rodríguez, Jorge, 67, 149, 176, 214-16, 275

$S$

social missions, 50, 115. See also specific misiones

social movements, 5, 10, 19, 101, $113,203,214$. See also grassroots movements sow the oil, 317

state

and anthropological theory, 161

and hierarchy, 90, 92, 94, 188, 214, 216

and labor laws, 169, 171

and neoliberal, 37, 38, 45, 59, 90, $98,173,226-8,262,273,314$, 327

and popular power, 1, 9, 11, 107, $111,114,120,121,130,131$, $135,136,149,152,152 \mathrm{n} 5$, $187,190,201,203,205-7$, $209,214,216,217$

and violence, 20, 23, 62, 73, 76, 78, $126,141,319$

strategic ambiguity, 5

$\mathrm{U}$

unemployment, 64, 74

United Nations, the, 256

United Socialist Party of Venezuela (PSUV), 153nl 1

Urban Land Committees, 117

V

Vega, la, 63

violence

and memories of, 23

during Puntofijismo, 23, 126

Viveza criolla, la, 292

W

Washington Consensus, 35 